\title{
Center for Strategic Studies and Debates
}

BRAZIL'S PATENT REFORM

INNOVATION TOWARDS

NATIONAL COMPETITIVENESS 


\section{BRAZIL'S PATENT REFORM: INNOVATION TOWARDS NATIONAL COMPETITIVENESS}




\section{CHAMBER OF DEPUTIES}

54th Legislature - 2011-2015

3rd Legislative Session

President: Henrique Eduardo Alves 1st Vice-president: André Vargas 2nd Vice-president: Fábio Faria

1st Secretary: Márcio Bittar 2nd Secretary: Simão Sessim 3rd Secretary: Maurício Quintella Lessa 4th Secretary: Biffi

1st Vice-secretary: Gonzaga Patriota 2nd Vice-secretary: Wolney Queiroz 3rd Vice-secretary: Vitor Penido 4th Vice-secretary: Takayama

\section{Director General}

Sérgio Sampaio Contreiras de Almeida

Secretary General of the Governing Board Mozart Vianna de Paiva 


\section{BRAZIL'S PATENT REFORM: INNOVATION TOWARDS}

NATIONAL COMPETITIVENESS

\section{Coordination}

Congressman Newton Lima

Technical Team

Pedro Paranaguá (Coordinator)

Laurez Cerqueira

Graziela Zucoloto

André de Mello e Souza César Costa Alves de Mattos

Fábio Luis Mendes

Mauricio Jorge Arcoverde de Freitas

Maíra Mendes Galvão (Translator)

Documentation and Information Center

Edições Câmara

Brasília - 2013 


\section{Center for Strategic \\ Studies and Debates}

President Congressman Inocêncio Oliveira

Members

Dr. Paulo César

Félix Mendonça Júnior

Jaime Martins

José Linhares

Leopoldo Meyer

Margarida Salomão

Mauro Benevides

Pedro Uczai

Ronaldo Benedet

Deputy Members

Antonio Balhmann

Colbert Martins

Iara Bernardi

Jesus Rodrigues

José Humberto

Miro Teixeira

Waldir Maranhão

Executive Secretary

Luiz Henrique Cascelli

de Azevedo

Institutional Coordinator

Paulo Antônio Motta

dos Santos

Secretariat Coordinator

Lúcio Meireles Martins

Centro de Estudos e Debates

Estratégicos - CEDES

Gabinete 566A - Anexo III

Câmara dos Deputados

Praça dos Três Poderes -

CEP 70160-900

Brasília DF

Tel.: (61) 32158626

E-mail:cedes@camara.leg.br www.camara.leg.br/cedes

\section{Chamber of Deputies}

Legislative Division

Head: Afrísio Vieira Lima Filho

Documentation And Information Center

Head: Adolfo C. A. R. Furtado

Edições Câmara Coordination

Head: Daniel Ventura Teixeira

Center for Strategic Studies and Debate

Head: Luiz Henrique Cascelli de Azevedo

Câmara dos Deputados

Centro de Documentação e Informação - Cedi

Coordenação Edições Câmara - Coedi

Anexo II - Praça dos Três Poderes

Brasília (DF) - CEP 70160-900

Phone: +55 +61 3216-5809; fax: +55 +61 3216-5810

editora@camara.leg.br

Adapted to English by Maíra Mendes Galvão, from Brazil's

Patent Reform: innovation towards national competitiveness, edited by Câmara Editions Coordination, 2013.

Reviser: Maíra Mendes Galvão

Graphic Design: Patrícia Weiss

Diagramming: Alessandra Castro König

Cover: Daniela Barbosa

SÉRIE

Estudos estratégicos

n. 2

Dados Internacionais de Catalogação-na-publicação (CIP) Coordenação de Biblioteca. Seção de Catalogação.

Brazil's patent reform [recurso eletrônico] : innovation towards national competitiveness / coordination: Newton Lima ; technical team: Pedro Paranaguá (coord.) ... [et al.] ; Maíra Mendes Galvão (translator). -- Dados eletrônicos. -- Brasília : Chamber of Deputies, Edições Câmara, 2013. - 1

(Série estudos estratégicos;n. l)

Modo de acesso: Internet.

$<$ http://www.camara.gov.br/..

Título da página da Web (acesso em 10 jul. 2013)

ISBN 978-85-402-0107-1 (e-book)

Adaptação para a língua inglesa da obra "A revisão da lei de patentes: inovação em prol da competitividade nacional”.

1. Brasil. [Lei de patentes (1996)], revisão. 2. Patente, Brasil. 3. Inovação tecnológica, Brasil. 4. Propriedade intelectual, Brasil. 5. Propriedade industrial, Brasil. 6. Patente de invenção, Brasil. I. Lima, Newton. II. Paranaguá, Pedro. III. Série.

CDU $347.77(81)$ 
"It is common to underestimate the role of ideas in the lives of peoples, and even more so in the lives of peoples who live from importing ideas."

Celso Furtado, “A Fantasia Organizada”. In Obra Autobiográfica. Rio de Janeiro: Paz e Terra, 1997, at 252.

"There is increasing recognition that the patent system, as currently designed, not only imposes untold social costs, but also fails to maximize innovation." 


\section{CONTENTS}

INTRODUCTION BY THE PRESIDENT OF THE CHAMBER OF DEPUTIES

FOREWORD BY THE PRESIDENT OF THE CENTER FOR STRATEGIC STUDIES AND DEBATES

INTRODUCTION

1. INCENTIVE TO INNOVATION THROUGH PATENT RIGHTS

1.1 Effects of Strengthening Patent Rights

1.2 The Brazilian case and its technological innovation indicators

1.3 The human right to health and the impact of patents

2. THE PATENTABILITY REQUIREMENTS AND PATENT QUALITY

2.1 Novelty

2.2 Inventiveness or Non-obviousness

2.3 Sufficiency of disclosure - enablement

2.4 Best mode

2.5 Legislative proposal

2.6 Recommendations

3. PRE-GRANT OPPOSITION 


\subsection{Recommendations}

4. NON-EXTENSION OF THE PATENT TERM

4.1 Legislative proposal

4.2 Recommendations

5. PUBLIC NON-COMMERCIAL USE

5.1 Public non-commercial use and the international legislation

5.2 Legislative proposal

5.3 Recommendations

6. PIPELINE PATENTS - OR REVALIDATION PATENTS

6.1 Pipeline patents in Comparative Law

6.2 Considerations

7. NEW FORMS OF KNOWN SUBSTANCES AND NEW USES

7.1 New Forms of Known Substances

7.2 New uses

7.3 The Brazilian Patent Office's examination guidelines, and the decision of the Inter-ministerial Group on Intellectual Property

7.4 Legislative proposal

7.5 Recommendations

8. THE SANITARY AGENCY'S (ANVISA) PRIOR CONSENT

8.1 Prior consent: the legal debate

8.1.1 The public class action, and the complaint to the UN

8.1.2 Inter-ministerial working group 
8.2 Restriction to patent applications under the pipeline mechanism

8.3 ANVISA's prior consent and its relevance to public health 147

8.4 Legislative proposal

8.5 Recommendations

9. UNDISCLOSED TEST DATA PROTECTION

9.1 Registration of generic medicines in Brazil, and the impact of data exclusivity

9.2 Undisclosed test data vs data exclusivity

9.3 Legislative proposal

9.4 Recommendations

10.SHAM LITIGATION

10.1 Recommendations

11. COMPULSORY LICENSE

11.1 Recommendations

12. GENETIC RESOURCES, TRADITIONAL KNOWLEDGE, AND BENEFIT SHARING

12.1 International legislations

12.2 The state of affairs in Brazil

12.3 Recommendations

13. PRIZE SYSTEM AS AN ALTERNATIVE TO PROMOTE INNOVATION

13.1 Open research, development and innovation model

13.2 Prize system

13.3 Recommendations 
15. PATENT PROSECUTION HIGHWAY (PPH)

15.1 Recommendations

16. PATENT BACKLOG AND PATENT QUALITY

210

16.1 Recommendations

17. CREATION OF THE COUNCIL OF INTELLECTUAL PROPERTY RIGHTS (CODIPI), AND THE ROLE OF THE INTER-MINISTERIAL GROUP ON IP (GIPI)

17.1 Legislative proposal

17.2 Recommendations

18. THE BRAZILIAN PATENT OFFICE (INPI):

HEADQUARTERS IN THE FEDERAL DISTRICT

18.1 Recommendations

19. EXECUTIVE SUMMARY

ANNEX I - Bill H.R. 5402/2013, (Dr. Newton Lima, and Dr. Rosinha)

ANNEX II - Decree Proposal for the creation of the Council of Intellectual Property Rights (CoDiPI)

ANNEX III - LAW No. 9279, OF MAY 14, 1996 


\section{INTRODUCTION BY THE PRESIDENT OF THE CHAMBER OF DEPUTIES}

The Center for Strategic Studies and Debates of the Brazilian Chamber of Deputies, founded in 2013, delivers to the public the first publication of the Strategic Studies series, developed from a wide-ranging debate set up to discuss the revision of patent legislation in the country.

Entitled The Revision of the Patent Act: innovation towards national competitiveness, the volume features Congressman Newton Lima as rapporteur, and seeks to outline paths towards the stimulus to innovation and the strengthening of the national industry.

Throughout 2011 and 2012 seven seminars were conducted at the Chamber of Deputies, the State University of Campinas (Unicamp), the Patent Office, and the University of São Paulo Law School.

Representatives of academia, research institutions, Brazilian and multinational industries, non-governmental organizations, Executive and Judicial Branches, as well as congressional representatives were invited to take part in the discussion. The issues were treated from the most diverse standpoints, taking into account the legislation and experiences of several countries, in order to produce stock for concrete actions in the scope of the Brazilian patent legislation.

The result is a well-fundamented and courageous work with its focus on the long-term development of Brazil that, once again, puts the Brazilian Chamber of Deputies in the vanguard of national political debates.

Congressman Henrique Eduardo Alves President of the Chamber of Deputies 


\section{FOREWORD BY THE PRESIDENT OF THE CENTER FOR STRATEGIC STUDIES AND DEBATES}

Every development process is the product of a medium and long-term strategy able to recognize potentialities and limitations in order to choose paths that ensure scientific, technological, economic and social advances compatible with the expectations of present society as well as the needs of future generations.

In this context, Brazil - that is in halfway between developing countries and world leaders faces the double challenge of promoting an increase in income and jobs as well as taking a leap in productivity to raise its competitive stakes in the international stage.

The search for a sustainable development model capable of ensuring jobs and income for the working population has become essential for the Brazilian society, that is looking for effective answers for the dilemmas present in a scenario of strong competition in all productive sectors, demanding at once efficiency to export and resistance to preserve the internal market.

The patent issue has been gaining higher ground in the national agenda while experience proves that a business' increase in productivity and improvements in competitiveness are strongly propelled by results yielding from innovation.

Each country seeks for foothold mechanisms towards an articulation that, on one hand, guarantees the recovery of investments in research and innovation and, on the other hand, a satisfactory distribution of benefits from the collectivity standpoint. In other words, every patent consents offering the exclusivity of protection against competition in the short term in exchange for the products of innovation in the long term.

The central issue for a country that needs to grow and free itself from the stigma of a peripheral economy is to know what to protect, as well as how and when to protect. The patent is not an end in itself, obviously, but should be inserted in the major national development strategy. 
The manner by which protection to property rights of technological innovations is done can stimulate local research and the creation of new products and processes, as well as shorten the paths towards productivity and self-sufficiency; but it can also discourage innovation and perpetuate dependent replication by the industry.

The present study was born from a wide-ranging debate promoted by the Brazilian Chamber of Deputies featuring specialists and representatives from all sectors interested in the formulation of a national patent policy able to offer alternatives in line with the present needs of the country.

The revision of the patent legislation hereby proposed has the fundamental goal of creating a favorable environment for innovation, so that the resulting productivity gains can translate into lasting foundations for the sustainable development of the Brazilian society.

Congressman Inocêncio Oliveira

President of the Center for Strategic Studies and Debates 


\section{INTRODUCTION}

Brazil does not want to be a mere exporter of commodities such as soybeans, cotton, oil and iron. Neither it wants to be a simple consumer of knowledge goods such as foreign films and music, medicines, software and technologies already developed in other countries. Brazil wants to be the stage of cutting-edge innovation. Brazil wants to empower its domestic industry. It wants to be competitive. Brazil wants to innovate to compete. ${ }^{1}$

That is the reason why Brazil's Government has created the "Plano Brasil Maior" or Greater Brazil Plan as a country-wide industrial, technology and foreign trade policy, in partnership with the private sector. The purchasing power of the public sector is very attractive to create businesses in the area of innovation and knowledge, such as the Industrial Health Complex. Likewise, encouraging the rooting of foreign companies and the installation of Research \& Development Centers in the country are priority goals. All in favor of capacity-building and national competitiveness.

As stressed by the Ministry of Science, Technology and Innovation, the Brazilian solution for innovation and competitiveness should follow, to some extent, its own way, and that takes into account the current stage of development of the country (ENCTI 2012-2015). ${ }^{2}$ Fostering innovation through patents should not follow different a path. Brazil should use its inherent creative ability to adapt and tropicalize its patent system to promote public policies for innovation in the country. So did India, when reviewing its patent act in 2005. And so did China, in 2008.

The three core results from this Report on "Brazil's Patent Reform: innovation towards national competitiveness" are:

1. Bill no. H.R. 5402/2013, that proposes the following amendments:

a) limits the patent term at 20 years maximum - the Patent Act in force authorizes the extension for beyond 20 years, when for instance

1 "Innovate to compete" is the slogan that the Brazilian Government uses on its "Plano Brasil Maior" (Greater Brazil Plan), a country-wide plan for science, technology and innovation.

2 See http://www.mct.gov.br/upd_blob/0218/218981.pdf 
the Patent Office takes more than 10 years to grant a patent - which happens in many pharmaceutical patents (Patent Act Art. 40, sole §);

b) clarifies matters that are not considered to be inventions: such as new use patents and new forms of known substances - along the lines of the Indian Patent Act as revised in 2005 (Patent Act Art. 10);

c) increases the standard of inventive step in order to promote incremental innovation - along the lines of the Indian Patent Act as revised in 2005 (Patent Act Art. 13 and 14);

d) creates a fully fledged pre-grant opposition mechanism (Patent Act Art. 31 and 31-A);

e) updates the Sanitary Agency's (ANVISA) prior consent mechanism for pharmaceutical patents (in accordance with the recently adopted ANVISA Resolution 21/2013), granting ANVISA the duty to analyze, prior to the Patent Office, patent applications involving pharmaceutical/ chemical i) products that have previously been rejected by the Agency, and thus present health risks, and ii) compounds that are of interest to support Brazil's National Health System (SUS in the Brazilian acronym) public policy, and that do not meet the patentability requirements set forth by the Patent Act (Patent Act Art. 229-C);

f) clarifies that the protection of pharmaceutical undisclosed test data in Brazil takes place in the form of unfair competition - and not data exclusivity (Patent Act Art. 195), and

g) implements in the Patent Act the public non-commercial use mechanism as set forth by the WTO TRIPs Agreement (Patent Act Art. 43-A).

2. Presidential Decree for the creation of the Council of Intellectual Property Rights (CoDiPI):

a) under the President's Office (the Inter-ministerial Group on Intellectual Property - GIPI, is currently housed by the Foreign Trade Chamber, under the Ministry of Development, Industry and Foreign Trade), to unify the country's intellectual property rights public policies;

b) give more power to the Council, by making its resolutions binding (currently, GIPI's resolutions are not binding); and

c) democratize the participation of other government bodies within the new Council, besides the Patent Office: including the Competition 
Body, the National Sanitary Agency, the Foreign Trade Chamber, the Brazilian Council for Genetic Heritage Management, as well as persons of notable knowledge in the field.

3. Recommendations to the Executive Branch - including to the Patent Office, the Competition Body, the Sanitary Agency, and so on.

I believe that the issues raised and analyzed in this Report are critical not only to Brazil, but to several other countries as well. For instance, India amended its patent law in 2005, following a 10-years transition period granted by the WTO TRIPs Agreement for the implementation of pharmaceutical product patents in countries where those patents were not allowed at the time the WTO was created - unfortunately, Brazil has not availed itself of this transition period.

The evergreening 2013 Novartis case in India, in which the Indian Supreme Court rejected the grant of a patent for a new form of a known substance, evidences how important the implementation of the TRIPs Agreement safeguards can be to a country, and indeed to the world, for India has become the major international provider of affordable generic medicines to the world's population. ${ }^{3}$

Argentina, for instance, using the WTO TRIPs Agreement flexibilities, has recently taken steps to review its patent examination guidelines in order to prevent the grant of patents for new forms of know substances, as well as to new use medical treatments, in order to adapt its patent law to that country's current stage of technological development. ${ }^{4}$

3 See Novartis v. Union of India \& Others, a landmark decision of the Indian Supreme Court on the issue of evergreening of pharmaceutical patents. The decision is a culmination of a seven-year-long litigation fought by Novartis for the granting of an Indian patent on imatinib mesylate in beta crystalline form which would thereby restrain Indian generic pharmaceutical manufacturers from producing drugs based on the compound. The Indian Supreme Court decided that the substance that Novartis sought to patent is known and thus does not qualify the test of invention as laid down in section 2(1)(j) and section 2(1)(ja) of the Indian Patent Act and rejected the patent application. The decision also for the first time tests the validity and ambit of section 3(d) of the Indian Patent Act that prevents the grant of a patent for new forms of known substances, unless the applicant can establish the new form demonstrates an increased efficacy. For an analysis of the Novartis case in India, see Achal Prabhala \& Sudhir Krishnaswamy, "Why Novartis case will help innovation", in The Hindu, Apr. 15, 2013, available at http://www.thehindu.com/opinion/lead/ why-novartis-case-will-help-innovation/article4617473.ece. See also Frederick M. Abbott, "The Judgment In Novartis v. India: What The Supreme Court Of India Said", in IP-Watch, Apr. 4, 2013, available at http:// www.ip-watch.org/2013/04/04/the-judgment-in-novartis-v-india-what-the-supreme-court-of-india-said/, and Achal Prabhala \& Sudhir Krishnaswamy, "The Law That Saved a Billion Lives", in Open, May 4, 2013, available at http://www.openthemagazine.com/article/nation/the-law-that-saved-a-billion-lives.

4 The Argentiniann patent examination guidelines, issued jointly by Argentina's Patent Office and the country's Health Department instruct patent examiners to reject (with some exceptions) new use, new form, and new formulation patents, and specify a number of other frivolous changes to drugs which are no longer acceptable. A 'new form' patent is a patent granted on minor variations of existing chemical entities/active pharmaceutical ingredients (isomers, salts, polymorphs etc). A 'new use' patent is a patent granted on a medicine that is found to be effective in treating a different disease than for what it is already registered and sold. A 'new formulation' patent is a patent that is granted for a new formulation of an already existing medicine (i.e. new dosages, new pill forms, new combinations). The Argentinian Patent Examination Guidelines may be found at http://www.moellerip.com/index.php?PN=news detail\&FX=1\&DX=139\&EX=1. 
Thailand has issued a number of compulsory licenses, in compliance with the WTO TRIPs Agreement, so as to provide access to affordable antiretroviral and heart disease medicines to that country's population. ${ }^{5}$

In South Africa, the "Fix the Patent Law Campaign" has been launched in order to review that country's patent law. ${ }^{6}$ The United States of America is also undergoing a patent reform, as we mention further in this introduction.

These are just a few recent examples of the growing empowerment of developing countries in the patent policy field. Those countries are learning how to better adapt the patent system to their local reality. All is done in compliance with the WTO TRIPs Agreement. And that is why countries should be cautious in signing TRIPs-plus instruments such as the Trans-Pacific Partnership (TPP) Agreement. ${ }^{7}$

Having said that, this Report, I understand, may serve not only the interests of Brazil, but also of other countries, mainly the developing ones. The minimum standards of patent rights are established by the WTO TRIPs Agreement, that leaves considerable lee room to adapt each country's patent laws to their own reality and current stage of technological development, and social and economic needs. I truly hope that this Report may serve as an inspiration to other developing countries to engage in the patent policy discussion, and to adapt their national laws to better serve their own public interests.

The proposal for conducting this Report on "Brazil's Patent Reform: innovation towards national competitiveness" presented to the Advanced Studies and Technological Evaluation Council at the Chamber of Deputies in Brasília was unanimously approved by its board members on 02 March 2011. This Report's initial goals were to analyze the observed disparity between the sizable production of knowledge in Brazilian institutions and the small number of national patents, as well as the difficult relationship between research and technological innovation institutes and the productive sector, as they factor into the economic and social development of the country. Since the Advanced Studies and Technological Evaluation Council was terminated in the beginning of 2013 and

5 For more information, see the Program on Information Justice and Intellectual Property (PIJIP) page at https://www.wcl.american.edu/pijip/thai_comp_licenses.cfm.

6 Fix the Patent Laws is a South African campaign of the Treatment Action Campaign (TAC), a non-profit organization that seeks to ensure that every person living with HIV has access to quality, comprehensive prevention and treatment services to live a healthy life. More information available at http://www. fixthepatentlaws.org/. For a detailed analysis of the South African patent system and the possible and needed amendments it should undergo, see Chan Park and Achal Prabhala, "TRIPs flexibilities, access to medicines and the domestic pharmaceutical industry in South Africa: An analysis of patents, competition and medicines law", United Nations Development Programme, Regional Service Centre for Southern \& Eastern Africa, Nov. 2007.

7 More information on the TPP Agreement, see the Knowledge Ecology International's (KEI) website at http://keionline.org/tpp, and the Electronic Frontier Foundation's (EFF) blog on the top at https:// www.eff.org/issues/tpp. 
substituted by the new Center for Strategic Studies and Debates, the present Report is launched within this new Center.

The debates, which took place over seven public hearings in 2011 and 2012, saw the addition of other themes to a setting that evidenced the need for legislative changes as well as the appointment of other measures to the Federal Executive Branch aimed at overcoming the issues that, in a sense, create obstacles for technological evolution and barriers to market competition, consequently backtracking the country's economic and social development.

The Executive Secretary of the Ministry of Science, Technology and Innovation (Ministério da Ciência, Tecnologia e Inovação - MCTI), Mr. Luiz Antônio Elias, gave a lecture before the former Advanced Studies and Technological Evaluation Council at the Chamber of Deputies on innovation and patents on 10 August 2011. The "Technological Innovation, Intellectual Property and Patents" public hearing was hosted on 17 August 2011 by the Science and Technology Commission at the Chamber of Deputies with the participation of representatives from the Ministry of Development, Industry and Foreign Trade (Ministério do Desenvolvimento, Indústria e Comércio Exterior- MDIC), the Ministry of Foreign Relations (Ministério das Relações Exteriores - MRE) and the MCTI, and also counted on representatives from industry and academia.

Four other debate cycles aimed at further exploring the previous discussions were launched: on 5 October 2011 at the Chamber of Deputies in Brasília; on 17 October 2011 at the State University of Campinas (Unicamp), in Campinas; on 27 October 2011 at the Brazilian Patent Office (Instituto Nacional da Propriedade Industrial - INPI) ${ }^{8}$, in Rio de Janeiro, and on 7 November 2011 at the School of Law of the University of São Paulo (USP) in São Paulo. The focus of each debate cycle was, respectively: i) the productive sector (Chamber of Deputies), ii) research and development actors (Unicamp), iii) the institutional perspective (the Brazilian Patent Office), and iv) casting light upon patent legislation (USP).

After the two events in August 2011 and the four debate cycles, it became apparent that the civil society sector had been under-represented in the discussions. It was decided, then, that a seventh and last debate should be added to the cycle with a special focus on the chemical and pharmaceutical sector, which took place on 29 May 2012, offering an opportunity for non-governmental organizations (NGOs) that did not have enough space in the former debates to present their positions regarding patents, pharmaceuticals and innovation. Representatives from academia, the pharmaceutical industry, as well as from the Federal Executive Branch and the Judiciary also took part in the debate.

8 The INPI is also commonly referred to as the Patent and Trademark Office (PTO) or simply the Brazilian Patent Office. 
Those seven debates throughout 2011 and 2012, with the participation of over 30 specialists representing a large array of sectors (the Brazilian Patent Office, research funding institutions, academia, attorneys representing large foreign corporations, the Federal Executive Branch, a national industry organization, an association specializing in the area, NGOs, members of the Judiciary, among others) made possible the collection of material to accomplish this Report.

These subsidies have been organized taking into account a questionnaire that has guided, to some extend, the discussions. Due to limited resources for the translation into English, the contributions received as reactions to the questionnaire are not part of the English version - but may be found in its entirety in the Brazilian Portuguese version. This does not compromise, however, the present Report, for the questionnaire was a very initial guide, and in furtherance to that, nearly a whole year of research ana alasys took place in order to better develop this Report.

Accordingly, in addition to the discussions brought by the participants of the seven above mentioned debates, an extensive national and foreign bibliography was examined, including three independent reports commissioned by the government of the United Kingdom, as well as two reports from the United States of America's Federal Trade Commission. The patent legislations in Argentina, China and India, recently revised, were also analyzed. Several documents by the United Nations and its specialized agencies were equally consulted. Academic papers and books, both national and foreign, also served as a basis for this Report.

This Report is not and does not intend to be exhaustive. After an introduction to the scope of this Report, the themes are distributed into 19 chapters. Chapter 1 deals with the incentive to innovation by means of patents rights; with the effects of the strengthening of those rights; of a few innovation indicators in Brazil; as well as the impact of patents in the human right to health.

Chapter 2 deals with patentability requirements and patent quality. The pre-grant opposition to patent rights is examined in Chapter 3. Chapter 4 considers the nonextension of patent term. The public non-commercial use is investigated in Chapter 5. Revalidation or pipeline patents are discussed in Chapter 6. New forms of known substances and second medical uses are the subject of Chapter 7. Chapter 8 discusses the Sanitary Agency's (ANVISA) prior consent for pharmaceutical and chemical patents. Chapter 9 goes over the protection of undisclosed test data. Chapter 10 examines patent abuse through lawsuits (sham litigation). Compulsory licenses are discussed in Chapter 11. Genetic resources, traditional knowledge, and benefit sharing are analyzed in Chapter 12. Chapter 13 approaches the Prize System as an alternative to promote innovation. Software patents are examined in Chapter 14. The Patent Prosecution Highway (PPH) is assayed in Chapter 15. Chapter 16 deals with patent backlog. Chapter 
17 scrutinizes the role of the Inter-ministerial Group of IP (GIPI) and the creation of the Council of Intellectual Property Rights (CoDiPI), linked to the President's Office. Chapter 18 talks about bringing the Brazilian Patent Office headquarters to the Federal Capital. Finally, Chapter 19 presents an executive summary of this Report.

Annex I contains proposals for legislative revision: Bill no. H.R. 5402/2013, cosponsored by me and Representative Dr. Rosinha (Workers Party - Paraná). In Annex II one will find the suggestion for a Presidential Decree for the creation of the Council of Intellectual Property Rights (CoDiPI), under the President's Office. Annex III contains the Patent Act (Industrial Property Act - no. 9279/96).

Chapters 1 and 12 were developed in collaboration with the Institute of Applied Economic Research (Instituto de Pesquisa Econômica Aplicada - IPEA), under the Secretariat of Strategic Affairs (Secretaria de Assuntos Estratégicos) of the President's Office. Economist Graziela Zucoloto, PhD, and political scientist André de Mello e Souza, PhD collaborated with those two chapters.

I am indebted to Mr. Pedro Paranaguá, advisor to the ruling Workers Party in the Chamber of Deputies, for Internet, copyright, cybercrime, patents, online privacy, and related matters, who tirelessly coordinated and aided building this Report. I also counted with the strategic collaboration of Mr. Laurez Cequeira, my then personal advisor.

Indispensable contribution and institutional support were imparted by Consultant Mr. Paulo Antônio Motta dos Santos, the Center for Strategic Studies and Debates' Coordinator of Institutional Affairs, and by then Coordinator of the Secretariat Mr. Márcio Coutinho Vargas. Congressman Mr. Inocêncio Oliveira, President of the extinct Council, and now new Center, offered all the necessary institutional support for the fruition of this Report. The Legislative Consultancy of this Chamber of Deputies, coordinated by Mr. César Costa Alves Mattos, PhD, prepared a summary of the speakers' presentations and their answers to the questionnaire (available in the Brazilian Portuguese version), by means of an invaluable collaboration with Mr. Fábio Luis Mendes and Mr. Mauricio Jorge Arcoverde de Freitas.

The the present technical analysis does not, and it does not intend to, advocate against the patent system. Patent law, if duly balanced with other fundamental rights provided for under Article 5 of the Brazilian Constitution, should promote technological innovation, as well as access to those very innovations, striking a balance between exclusivity and competition. ${ }^{9}$ In this regard, the United States Federal Trade Commission is clear:

9 A position shared by the Federal Trade Commission of the U.S. (the equivalent government body in Brazil is Conselho Administrativo de Defesa Econômica - CADE) in their report entitled The Evolving IP Market Place - Aligning Patent Notice and Remedies with Competition, 2011, p. 1. Available at http://www.ftc.gov/ os/2011/03/110307patentreport.pdf. 
Invalid or overbroad patents disrupt that balance by discouraging follow-on innovation, preventing competition, and raising prices through unnecessary licensing and litigation. ${ }^{10}$

Without proper balance, the patent system fails to exercise its Constitutional role and consequently must be reformed (by the Legislative), reinterpreted (by the Judiciary), and its public policies must be reconsidered (by the Executive Branch), so as to achieve the balance needed for the promotion of economic, social and technological development in Brazil, in compliance with the patent clause of the Brazilian Constitution (Art. 5, XXIX).

Commenting on the undue use of the patent system, a Cisco executive has stated:

So obtaining patents has become for many people and companies an end in itself, not to protect an investment in research and development, but to generate revenue through licensing ("holding up") other companies [...]. They try to patent things that other people or companies will unintentionally infringe and then they wait for those companies to successfully bring products to the marketplace. They place mines in the minefield. The people and companies [...] play the patent system like a lottery [...]. They benefit from the high cost of litigation by demanding license fees that are less than the cost of litigation, hoping that people will pay even if they don't infringe [...]. It's hard to see how this contributes to the progress of science [...]. ${ }^{11}$

It is remarkable that the patent laws of several countries have not, unfortunately, been operating according to their goals, namely the promotion of technological innovation and technology transfer towards social and economic development.

President of the United States Barack Obama has admitted, in the beginning of 2013, that in certain fields some patent holders are "just trying [through their questionable patents] to essentially leverage and hijack somebody else's idea and see if they can extort some money out of them." Mr. Obama goes on: "Because we also want to make sure that patents are long enough, and that people's intellectual property is protected. We've got to balance that with making sure that they're not so long that innovation is reduced." Therefore, Mr. Obama admits that, to the U.S., patents are important tools for technological, scientific, economic and social development, but, if balance is not established, then those very same patents can cause the opposite effect of hindering innovation and development. That is why their patent law was reviewed and that is why

10 See FEDERAL TRADE COMMISSION, The Evolving IP Market Place - Aligning Patent Notice and Remedies with Competition, 2011, p. 1.

11 See Commission on Intellectual Property Rights. Integrating intellectual property rights and developing policy, Report of the Commission on intellectual property rights, London, UK 2002. Available at http:// www.iprcommission.org/papers/pdfs/final_report/ciprfullfinal.pdf. 
Mr. Obama admits that the continuation of this review process is necessary, as it is, in his own words, "about halfway to where we need to go".12

The Prime Minister of the United Kingdom, at the time of the commission of the Hargreaves Review of Intellectual Property and Growth, in 2011, came up with the following question for Professor Ian Hargreaves, in charge of the Review: "Could it be true that laws designed more than three centuries ago with the express purpose of creating economic incentives for innovation by protecting creators' rights are today obstructing innovation and economic growth? The short answer is: yes."13

As Nobel Prize laureate Joseph Stiglitz suggests, "there is increasing recognition that the patent system, as currently designed, not only imposes untold social costs, but also fails to maximize innovation". 14

This Report analyzes selected aspects of the patent system in Brazil in need of reformulation to assist solving some of its problems. This Report has taken on a technical approach and thus does not intend to be academic. In any case, the arguments brought up here were, as mentioned before, based on public hearings, empirical evidence, national and international reports, academic papers, foreign legislation, among others.

Moreover, it is worth highlighting that a government program for the promotion of technological innovation in the country must not be based solely and exclusively in the patent system. Patents are not synonymous with innovation. As a matter of fact, if the patent system is not sufficiently balanced, it may end up promoting an innovation block, as suggested by some of the previous statements, and as demonstrated by this Report. That is precisely why the Brazilian Federal Government launched, in the beginning of 2013, the "Inova Brasil" program by means of the Financing Agency for Studies and Projects (Financiadora de Estudos e Projetos - Finep), housed at the Ministry of Science, Technology and Innovation (MCTI) - that does not necessarily understand the patent system as the only means for promoting innovation.

Bearing in mind the functions and legal attributions of the Chamber of Deputies, by the end of each chapter, we present recommendations in the form of propositions to the Legislative Branch, as well as recommendations to the Executive Branch. The recommendations are either made through proposals for hard-and soft-law amendments or via administrative measures to be adopted by the government bodies to which the recommendations are addressed to.

12 See Joe Mullin, Even Obama knows patent trolls are "extorting" money. Available at http://arstechnica. com/tech-policy/2013/02/even-obama-knows-patent-trolls-are-extorting-money/.

13 See lan Hargreaves, Digital Opportunity. A Review of Intellectual Property and Growth. An Independent Report by Professor lan Hargreaves, 2011, p. 1.

14 See "Intellectual Property Rights Gone Wild", May 12, 2013, available at http://www.slate.com/articles/ business/project_syndicate/2013/05/gene_patents_the_case_of_myriad_genetics_shows_the_dangers_ of_overly_protecting.html. 
Ultimately, in light of the country's national interest, this Report aims at: i) providing stock for a legislative review in the field of patent law; ii) proposing recommendations for interpreting and applying the patent legislation by the Patent Office, among others government bodies, and iii) helping on decision-making processes regarding public policies for the country's development.

As I have stressed above, I truly hope that this Report may serve not only the public interest of Brazil, but of other developing countries as well. The Novartis case in India, the steps Argentina has taken, the "Fix the Patent Law Campaign" in South Africa, amongst other cases, evidence that we have a chance to build international momentum and re-address the patent policies in developing countries in order to better serve their local needs of access to medicines, technological innovation, and capacity-building. 


\section{INCENTIVE TO INNOVATION THROUGH PATENT RIGHTS}

The patent system, whether national or international, has been conceived to make an exchange possible between the public and private spheres. This system is established by the granting of temporary exclusive exploitation rights, ${ }^{15}$ characterized as a temporary legal monopoly bestowed upon the inventor in exchange for his or her obligation of revealing his or her invention completely and listing his or her claims in a sufficiently descriptive manner so that a person having ordinary skill in the art is able to develop the invention in its entirety, a knowledge that will be immediately available for the general public, representing additional knowledge for society. ${ }^{16}$

Many have argued that the primary goal of this exchange is to stimulate private investment in innovation through the possibility of obtaining remuneration for research and development represented by the legal monopoly term for exploitation of the invention.

Such is the so-called "theory of investment incentive" ${ }_{17}^{17}$ which recognizes the inventor as holder of the exclusive exploitation rights as a way of remunerating for the investments made during the development of the invention, by means of accumulation of income from legal monopoly during the patent term. The patent is, therefore, a modality of incentive to the development of innovation.

In the case of developing countries, innovation and manufacturing activities are not always developed locally - therefore, without encouragement towards job and income generation, and without training and local technological development. Faced with this specificity, clauses for promotion of technology transfer were implemented in several

15 By exploitation, it should be understood manufacture, use, making available for sale, sale, and importation, according to art. 42 of Brazil's Patent Act no. 9.279/96.

16 From here on, we will use the expression "temporary legal monopoly" to identify patents. It is imperative to mention that patents are not necessarily market monopolies, in the economic sense used in the competition law jargon - but that they may come to be, in some cases. In order to differentiate patents from the traditional market monopoly - which is a monopoly de facto and not de jure, as the one created by patent law - we decided to use the expression "temporary legal monopoly".

17 Several theories were developed throughout the years to serve as basis for patent rights. We can summarize them in five main theories: i) theory of natural rights, ii) contractual theory, iii) reward theory, iv) incentive theory and v) theory of investment incentive. The first of them brings the classic naturalistic explanation for the legal institutes: the creator has a natural right to the patent. The second one sees the patents as a reward from the community to the inventor for the publicization of their discovery. The incentive theory is very similar to the contractual theory, but the reward is given for the incentive to well being represented by the patent. Finally, the incentive theory sees parents as a protection and an incentive for investments made by companies towards the development of inventions. It is, therefore, an incentive for competition among businesses. According to this theory, it is rarely possible to identify the inventor in the modern business world; inventions are usually a collective work from a business organization. Thus, an individual incentive to the inventor would bear little value. For a critical view of such theories, see: SALOMAO FILHO, Calixto. "Direito industrial, direito concorrencial e interesse público". Revista de Direito Público da Economia, Belo Horizonte, year 2, no. 7, 2004, at 29 and following. 
international instruments. In that sense, the Agreement between the World Intellectual Property Organization (WIPO) and the United Nations (UN) makes a clear point on the objective of intellectual property rights ${ }^{18}$, which consists of "promoting creative intellectual activity and for facilitating the transfer of technology related to industrial property to the developing countries in order to accelerate economic, social and cultural development [...]".

The leading international instrument regarding intellectual property rights nowadays is the World Trade Organization's (WTO) Trade-Related Aspects of Intellectual Property Rights Agreement - TRIPs. Regarding the objective of intellectual property rights, TRIPs Article 7 sets forth that the "protection and enforcement of intellectual property rights should contribute to the promotion of technological innovation and to the transfer and dissemination of technology, to the mutual advantage of producers and users of technological knowledge and in a manner conducive to social and economic welfare, and to a balance of rights and obligations." ${ }^{19}$

\section{OBJECTIVE OF THE PATENT SYSTEM}

The patent system was not conceived as an end in itself. Protecting patents is not the objective of the patent system. The objective is to promote innovation, technological advancement as well as technology transfer, with equitable remuneration for the inventor towards a larger goal: promoting scientific, economic, social and technological development. The patent system is, therefore, a means, and not and end in itself.

According to the Commission on Intellectual Property Rights (CIPR) Report from the Government of the United Kingdom, "developing countries should try to devise patent systems to take account of their particular economic and social circumstances."

18 See WIPO, Agreement between the United Nations and the World Intellectual Property Organization, available at http://www.wipo.int/treaties/en/agreement/index.html, accessed in 29.10.2012. The generic expression "intellectual property" includes not only industrial property rights but also copyright. The latter comprises both copyright per se as well as related rights, including the rights of performing artists, audiovisual producers, sound recorders, and the rights of broadcasters (Copyright Act 9.610/98). And industrial property rights include trademarks, patents and utility models, industrial designs, geographic indications and repression against unfair competition (Patent Act no. 9.279/96). The TRIPs Agreement deals with some intellectual property rights such as author's rights and related rights, trademarks, geographic indications, industrial designs, patents, topographies of integrated circuits, protection of undisclosed information and repression against unfair competition. There are also other types of knowledge goods, such as traditional cultural expressions, genetic resources and benefic sharing, semiconductors, plant seed rights, among others.

19 See TRIPs Agreement, available at http://www.wto.org/english/docs_e/legal_e/27-trips_01_e.htm. Access: 29 October 2012. Implemented by Decree 1.355/95. 
Moreover, according to the same Report, developing countries that are more technologically advanced

[...] would need to have adequate safeguards to ensure a competitive environment, and to minimise costs for consumers. Because much of the scientific and technological expertise in developing countries is concentrated in the public sector, there will need to be careful consideration of the implications of patenting by research institutions and universities. ${ }^{20}$

In line with neoclassic economy tradition, knowledge is a public good and, as such, the marginal cost for a new user to employ it is - or tends to be - zero. Therefore, the innovator cannot, obtain extraordinary profit from the knowledge he produced since it will be accessible to his competitor free of cost. Under a perfect competition regime, there would be no incentive for private agents to invest in the generation of new knowledge. The grant of temporary legal monopolies to innovators through patents arises as an incentive to the generation of innovation by guaranteeing appropriation conditions for the resources invested in the generation of new technologies.

Given that in a perfectly competitive market the cost of replication of innovations tends to be zero, the value of innovation would stem from its legal monopoly. Under that perspective, the necessary incentives to the generation of new knowledge and technologies would concern the transformation of a public good - knowledge - into a private good by means of the patent (DOSI, MARENGO and PASQUINI, 2007).

That way, the grant of a temporary monopoly for a given invention would fill the role of creating an "artificial scarcity" of goods that are not naturally scarce, affording them commercial value. In that sense, there is an economic theory that states that knowledge is a public good with the intrinsic feature of non-rivalry and non-excludability. Thus, any knowledge considered a global public good (including patent information) could be employed without interfering on its use by interested parties. ${ }^{21}$ Overall, although patent rights create inefficiencies, they would be the price paid for the production of new inventions and so that they will become public in the end.

Brazil adopted its first industrial property law in 1809. The current patent law in force is Law no. 9279 of 14 May 1996, known as the Industrial Property Act (Lei de Propriedade Industrial - LPI) or simply the Patent Act, in force since 15 May 1997. On the course of this Report we will refer to it as the Patent Act. It is crucial to highlight, nonetheless, that the above mentioned Act comprises not only patents but also other types of related rights.

20 See United Kingdom, Commission on Intellectual Property Rights (CIPR), Integrating Intellectual Property Rights and Development Policy, Londres, 2002. Available at http://www.iprcommission.org/papers/pdfs/ final_report/ciprfullfinal.pdf.

21 See Keith Maskus and Jerome H. Reichman, "International Public Goods and Transfer of Technology Under a Globalized Intellectual Property Regime", Cambridge University Press, 2005. 
Before the creation of the WTO, it was the World Intellectual Property Organization WIPO, created in 1967, in force since 1970, that dealt with intellectual property rights. The leading international agreement on the issue used to be the Paris Convention for the Protection of Industrial Property - CUP, of 1883, which is still in force to this day, with revisions, Brazil being a contracting member since its creation. In 1974, WIPO became a specialized body of the UN system.

TRIPs mandates a minimum standard for the grant of rights that must be implemented by all WTO member states in their national legislations. TRIPs is, therefore, a contract-treaty. It is not self-applicable. It is only valid among member states. It must be obligatorily implemented in each country's legal framework to become valid locally. TRIPs is otherwise valid only between member states but not within each country's internal legal system.

Aside from the creation of a minimum rights threshold, TRIPs went on to have what some would call "tooth and nail". If one of the member states violates the rules established by TRIPs, any country with grounds to believe they were harmed can initiate consultations before WTO and, in case it proves insufficient in solving the conflict, they can require a panel investigation with the WTO's dispute settlement body. If the Organization's arbiters understand that there was a violation of the WTO's rules, the infringing country will be subject to commercial penalties established by a multilateral body. That is a substancial advancement for global trade as, if the rules are not followed, the infringing country is subject to a legal embargo. It is a mechanism that stimulates member states to comply with WTO's rules.

Another fundamental issue is that each and any WTO member country must be bound to the TRIPs Agreement. The single undertaking principle establishes that, by taking part in the WTO, contracting members must automatically subscribe to all the agreements that integrate the Organization's package, among which is Annex 1C, the TRIPs Agreement. Thus, it is not possible to be a part of the WTO and reject the TRIPs Agreement on grounds of lack of interest. When a country chooses to be a contracting member of the WTO, it consequently needs to adopt the rules established in the TRIPs Agreement. In that sense, taking the expansion of global trade into account, almost all countries are presently WTO contracting members and, therefore, must observe the minimum standards established by TRIPs.

One of the chief changes brought by the TRIPs Agreement was the establishment of the mandatory grant of patent rights for all technology fields, including sectors for which many countries did not grant patents at the time, such as the pharmaceutical sector. It was a radical change because it was against the ruling principles at the time, according to which a pharmaceutical patent was incompatible with public health principles, 
especially in regard to the danger of speculative maneuvers regarding medicines, such as price-fixing and abusive prices, for instance, as well as causing medicine scarcity.

TRIPs established a deadline for developing, and least developed countries that did not recognize patents for some of the technological fields to start doing so. Developing countries, including Brazil, would have until 2005 to implement the minimum standards in their local legislation; and least developed countries would have until 1 July 2013 and for pharmaceutical patents, they would have until 1 January 2016, according to the Doha Declaration on the TRIPs Agreement and Public Health, signed in 2001.22 On 5 and 6 March 2013, the TRIPs Council gathered to decide on the extension of the deadline for the implementation of TRIPs in least developed countries, upon their suggestion that the deadline be extended until they are no longer on the UN list of least developed countries. Several developing countries such as Brazil have supported the measure, while developed countries were reticent. ${ }^{23}$

One of the chief advantages in this transition period would be allowing local companies to gather strength to face competition with transnational research and development (R\&D) businesses. As mentioned above, Brazil amended its patent legislation in 1996 to implement the TRIPs Agreement, but unfortunately

Brazil went further than the minimum standards required by TRIPs. ${ }^{24}$ Brazil, therefore, advanced this implementation in its national legal framework, to its own detriment, and declined the transition period that would allow the country's local industry to be prepared, which could place the country in a better position within the global competition system.

It was a lost opportunity. The pressure has resulted from the Office of the United States Trade Representative (USTR), by means of a legal mechanism known as Special 301 of that country's Trade Act, as well as from the some local manufacturers and from Brazilian patent attorneys with foreign clients.

22 See TRIPs Art. 65(4), available at http://www.wto.org/english/docs_e/legal_e/27-trips_08_e.htm, and Doc. WT/MIN(01)/DEC/2, available at https://www.wto.org/english/thewto_e/minist_e/min01_e/mindecl_ trips_e.htm.

23 See Catherine Saez, WTO: Wide Support For LDC TRIPS Extension, With A Hitch, IP-Watch, 06.03.2013, available at http://www.ip-watch.org/2013/03/06/wto-wide-support-for-ldc-trips-transition-extensionwith-a-hitch/.

24 Brazil was not obligated to implement a national exhaustion system, since the 6th article of TRIPs does not stipulate the mandatory adoption of any standards concerning the exhaustion of rights, whether national or international. The Industrial Property Act (9.279/96) has adopted the national standard in spite of the fact that the adoption of the international standard would at times promote wider access to technologies from foreign countries, which could be more effective in protecting the health of the Brazilian population, especially regarding essential medicines. Another legal device whose implementation was not mandatory for Brazil but did come to fruition to the country's own detriment was the pipeline system, provided in articles 230 and 231 of Act Lei 9.279/96. For further discussion on this topic, refer to Chapter 5 of this Report. 
Over the years preceding the TRIPs negotiations, the U.S. industry was lobbying their government to adopt measures that would force other countries to respect their knowledge goods. On the first half of the 1980s, the International Trade Center (ITC) strategically published the losses in the U.S. trade balance, arguably as a result of counterfeiting: US\$43-61 billion; and they also argued that from 1980 to 1987 that country's net exports surplus dropped from US\$27 billion to a deficit of US\$38 billion. It was the right moment to introduce restrictions to the access to knowledge goods, commonly referred to as intellectual property rights in the international trade agenda. ${ }^{25}$

With that intent, in 1984 the United States amended the Section 301 of their Trade Act of 1974 - which was amended again in 1988 and became known as Special 301 - to include the removal of tax preferences or the imposition of sanctions to countries that did not offer "adequate and effective" protection to U.S. intellectual property rights in foreign countries. Bearing in mind that not only the USTR but also any "interested party" may file a petition and start a "301 suit", private interest nongovernmental organizations (NGOs) were created to represent the U.S. industry, such as the International Intellectual Property Alliance (IIPA) and the Intellectual Property Committee (IPC), at that time formed by Bristol-Myers, DuPont, FMC Corporation, General Electric, General Motors, Hewlett-Packard, IBM, Johnson \& Johnson, Merck, Monsanto, Pfizer, Rockwell International and Warner Communications, to guarantee that their point of view would be duly represented.

Even then, according to the U.S. industry, the 301 suits were not sufficient, and, responding to pressure, the use of the Generalized System of Preferences (GSP) - which voluntarily and non-reciprocally exempts or reduces taxes for imports from developing countries - was also conditioned on the granting and enforcement of intellectual property rights. It was, therefore, the beginning of the connection between knowledge goods and international trade. And it is imperative to point out that, on the above mentioned cases - both with 301 suits and the GSP system -, those measures were, and still are, one-sided. The U.S. decides how and when it will take measures that arguably affect trade with other countries without, however, observing multilateral rules of international trade - such as the consultations that can be made in the scope of WTO or, if matters are not resolved, setting up a panel before the WTO's dispute settlement body.

In this growing scenario of increased protection of knowledge goods, negotiations at the 1986-94 Uruguay Round on the General Agreement on Tariffs and Trade began, under profound influence of technologically developed countries, especially the U.S., the European Community and Japan, all dominant in the pharmaceutical, software and

25 See Peter DRAHOS and John BRAITHWAITE. Information Feudalism: who owns the knowledge economy?, The New Press, New York, 2003. 
entertainment industries. The introduction of an Agreement with minimum standards for the granting of intellectual property rights, putting knowledge goods in the trade agenda, was one of the major goals for the industries in those countries, that also feared the strengthening of developing countries in the WIPO agenda and their revisionist initiatives for the intellectual property system.

The GATT/WTO negotiations involved an entire package of matters, and TRIPs was but one agreement among others such as the ones on textiles, and on agriculture. In that sense, the common argument is that the justification to the acceptance of the terms of TRIPs by the developing countries lies exactly on the fact that they had the "advantageous" terms of the Agriculture Agreement as a counterpart, serving as an incentive for exports. However, this simplistic explanation for the acceptance of TRIPs' terms by developing countries as a bargain in regard to the Agriculture Agreement does not sit well. Evidence points out that the protection of intellectual property rights has been expanding more and more to agriculture and related goods such as seeds, plants and agrochemicals like fertilizers and so son, which, ultimately, represents a dependency from the countries from the South to the technology that is largely retained by countries in the North.

In that sense, the Gowers Report from the Government of the United Kingdom makes it clear by stating that, even the minimum standards for intellectual property rights provided by TRIPs "have proven very burdensome for some developing countries". ${ }^{26}$ TRIPs-plus clauses, that is, clauses that go beyond the minimum standards mandated by TRIPs, are even more troublesome, such as pipeline patents, patents for new uses and new forms of known substances, as well as test data exclusivity; subject matters treated on Chapters 6, 7 and 9, respectively, of this Report.

The insertion of knowledge goods in the trade agenda and the inclusion of enforcement clauses on TRIPs have arrived to transform the global scenario permanently.

Developed countries, especially the U.S., Canada, Japan and European countries, understand that the minimum standards for intellectual property rights would lead to an adequate approach to those rights, favoring innovation and stimulating technology transfer. On the other hand, developing countries expressed concern on the asymmetries among countries, chiefly in regard to the national capacity for technology production, and sought efficient mechanisms for technology transfer. Moreover, they also showed concerns about ensuring their populations' access to new technologies. ${ }^{27}$

26 See UNITED KINGDOM, Gowers Review of Intellectual Property, report by the Government of the United Kingdom, 2006, p. 59.

27 See Jayashree Watal, Intellectual Property Rights in the WTO and Developing Countries, Oxford, New Delhi, 2003. 
In the context of the TRIPs Agreement negotiations, the patent system's declared goal was to promote technological innovation and make possible technology transfer and diffusion by means of foreign direct investment, in a manner conducive to social and economic well-being (Article 7, TRIPs).

Developed countries shared the understanding that the more comprehensive the protection to intellectual property is, the better for the development of all countries. Thus, the present intellectual property system has been built with two main goals: i) promoting innovation and ii) facilitating technology transfer to developing countries in order to catalize social and economic development.

TRIPs defenders should know better than any developing country that patent rights and related rights would be more of an instrument to strengthen their national companies with world exposure, as well as the revenue from technology produced by those companies and their research centers, than a tool to promote the development of countries that were not industrialized or that only had small-scale businesses, lacking technology centers and sufficient resources to bear with the demands towards the production of innovative technology.

Any exception to those premises is a subject surrounded by controversy, such as, for instance, the existence of talented scientists in developing countries, or the technological development of a given business, for they could be tackled by industrialized countries through braindrain, or through the acquisition of companies in peripheral economy countries.

\subsection{Effects of Strengthening Patent Rights}

The discrepancies in the level of technological development observed among companies would be determined by their characteristics, capacities and strategic choices. In consequence, intellectual property rights may not be essential in inducing inventive activities seeing as, in many industries, leadership or a pioneering position in the commercialization of a new product is enough to generate extraordinary profit and, in those cases, patents would not be primordial towards development. ${ }^{28}$ Therefore, formal protection would have, optimistically, a secondary role in the incentive to innovation (DOSI, MARENGO and PASQUINI, 2007).

Dosi, Marengo and Pasquini (2007) present several counterexamples to the causal relationship between patent rights and the development of new technologies, especially the information and communication technologies segment. The latter produced several innovations that amounted to significant economic value, even without being patented.

28 Akio Morita, founder of Sony, describes the importance of a pioneering spirit when it comes to patents in his autobiography "Made In Japan, Akio Morita e a Sony", Cultura, 1986. 
Logical support (software) and mobile telephones industries are examples of new technology and products that arose in an environment that hardly used any patent rights.

For the authors, that kind of exposure may have been the stimulating factor to the rapid growth of those sectors, given that knowledge dissemination stimulated innovation with the strengthening of the industrial property regime that began in the $80 \mathrm{~s}$ as a consequence, and not the cause, of the expansion of the ICT sector.

Regarding the promotion of innovation, organisms such as the Academy of Sciences and the U.S.'s Federal Trade Commission have already indicated that the quality of patents issued has been deterioration and that analysis standards for patentability requirements has become excessively low, allowing for the granting of several low quality patents that unduly affect the public domain and bring negative consequences to innovation ${ }^{29}$.

The report produced by the Organization for Economic Cooperation and Development (OECD) in 2004 comes to the conclusion that a preliminary investigation about whether or not the patent system works reveals its limited adequacy towards improving innovation and the diffusion of technology (OECD) $)^{30}$. The validity of this argument is demonstrated by the fact that...

\section{"CAUSE AND EFFECT" \\ BETWEEN PATENT RIGHTS AND HIGH DEVELOPMENT LEVELS HAVE NOT BEEN PROVEN}

Several developing countries have widely welcomed patent laws and were in no better position in terms of sensible improvement in their economic, technological or innovation development.

There are, in fact, studies that show an existing correlation between strong patent and related rights and high development levels in some countries. However, as the British Governments' Gowers Report indicates, the evidence is inconclusive. It is true that a relationship between strong patent rights and high development levels was demonstrated, but a relation of cause and effect could not be proven. ${ }^{31}$

Other factors that have a direct influence on how society's agents act and react when some patent and related right is cause for dispute are the capacity to monitor the market,

29 FEDERAL TRADE COMMISSION. To promote innovation: the proper balance of competition and patente law and policy. 2003. See also, JAGUARIBE, Roberto and BRANDELLI, Otávio. Propriedade intelectual: espaços para os países em desenvolvimento. In Propriedade intelectual: tensões entre o capital e a sociedade. Fábio Villares (org.). São Paulo: Paz e Terra, 2007. pp. 277 and 290.

30 ORGANIZATION FOR ECONOMIC CO-OPERATION AND DEVELOPMENT. Patents and innovation: trends and policy challenges. Paris, 2004, p. 28. Apud JAGUARIBE, Roberto and BRANDELLI, Otávio. Propriedade intelectual: espaços (...), op cit. p. 291.

31 See UNITED KINGDOM, Gowers Review of Intellectual Property, report by the government of the United Kingdom, 2006, p. 58. 
litigation expenses, the competence of hired attorneys, the power of negotiation among interested parties, the standpoint of the courts involved, among others. Koen (1991) apud Cimoli and Primi (2008) reveals cases in which small and medium businesses in the United States were aware of violations of their patent and related rights, but most of them did not act on it legally because of the lofty costs and the length of legal disputes.

Among the social costs involved in the process of protection of intellectual property rights, the following also stand out: i) the cost of the investment opportunity in selected technological trajectories (choosing inventive paths that will not necessarily lead to the best product or innovative process, but with a better chance at obtaining a patent); ii) transaction expenses, characterized by the need to run the patent system and to see that it is observed; iii) expenses regarding the deposit of an array of inter-related products and/or processes aimed at blocking the access to the other competitors in given technological spaces; iv) ah excessive quest for patents, a position that generates elevated financial costs; v) payment of royalties as a social cost; vi) rise in prices of imported products; vii) rise in prices for acquisition and utilization of new technologies; viii) loss of economic activity due to limiting imitation; ix) possibility of abuse of prices from patent holders; $x$ ) limitation of the access to new technologies due to the possibility of charging elevated prices during the legal monopoly term; among others.

The main criticism to the positive causality between the establishment of patent rights and generation of technological innovation focuses on the fact that, without the development of scientific and technological training, no patent system will be able to promote the generation of innovation, or even to promote competition and the competitive spirit that are associated to the idea of innovation, that is, in more specific terms, the creation of businesses geared towards the production and development of new products or technologies.

For Lall and Albaladejo (2002), weak patent and related rights can help businesses in the initial stages of development to build such technological training by means of imitation and reverse engineering. This phenomenon was observed in several countries that are nowadays developed, which employed a low level of protection to patents in their initial stages of industrialization to promote their development, increasing the protection as they caught up with leading economies. 


\section{IMITATION WAS ESSENTIAL TO TODAY'S DEVELOPED COUNTRIES}

According to Chang (2001 and 2009), the historical experience of countries that are today developed reveals that a strong protection to patents was not an essential condition to their economic development. Most of them adopted a lighter, incomplete, system of protection until they caught up with the advanced stages of development, and many violated other countries' patent rights. ${ }^{32}$

Holland, for instance, has integrally revoked their patent act for 47 years, from 1869 until 1910, so that the country could freely imitate the inventions in the chemistry field from Germany, their neighbor. ${ }^{33}$

And, after consolidating their technological position, those countries that had adopted weak protection, or even abolished their patent laws, took their turn in perfecting the international system of patent protection and demanding protective parity from countries that had not yet matured, and that had not achieved a substantial level of technological development according to the standards set by the now developed nations.

Experiences of countries such as Germany, Japan and Switzerland indicate that a low protection level was a central factor in the strengthening of their productive capacities and $\mathrm{R} \& \mathrm{D}^{34}$. After overcoming their technological gap, presently developed countries have strengthened their patent and related rights, limiting access of the others to innovations they generated and, as such, have dominated technology generation and patenting in a global level. United States, Germany and Japan account for approximately $80 \%$ of the patents issued in the United States Patent and Brand name Office (USPTO) nowadays (CIMOLI and PRIMI, 2008). Thus, developed countries maintain technology control in the international market and have set out to divide nations into two classes: the technologically capable, and the others.

32 See also, Fábio Konder COMPARATO, A transferência empresarial de tecnologia, 1984.

33 See Adam B. JAFFE and Josh LERNER, Innovation and Its Discontents - How our Broken Patent System is Endangering Innovation and Progress, and What to Do About it, Princeton, 2004, pp. 86-90.

34 Germany, by adopting the industrial property system, did not allow the patenting of chemical products, only their production processes. Behind that decision was the need to stimulate industrial innovation by encouraging research towards more efficient processes regarding the targeted product. That strategy is considered one of the pillars of the technological success achieved by the German chemical industry since the end of the 19th century. As for Switzerland, in the 19th century, they did not have an industrial property law, but they became one of the most innovative countries in the world, inventing textile machinery, steampowered devices and food processors. The introduction of an industrial property legislation in Switzerland in 1907 did not appear to bring any significant growth in inventive activities. The author concludes that, in the case of the Swiss, the absence of such legislation has collaborated with the technological and industrial development of the country. More recently, Switzerland conducted an empirical study with 350 companies in the biotechnology field to understand how to propitiate an innovative position in the long term. As a result, the country opted for imposing limits to the protection of biotechnological inventions aimed at preventing research from being halted and consequently hidnering technological development in the field. (Chang, 2001; Li, 2008). 
Aside from this dominance by a few countries, one can also observe that world patenting is concentrated in transnational companies. Sefarti (2008) highlights that, since the mid-80s, the number of patent families ${ }^{35}$ more than doubled and, in this process, those large companies have dominated the patenting process.

For the author, intangible assets such as patent rights are the most recent form of capitalization of multinational companies, which have been turning into financial centers with industrial activities, that is, they prioritize the generation of income by means of patent rights and financial processes to the detriment of their productive activities.

In this context, expenses and revenue for technology licensing have sped up considerably over a short period of time: in the United States, it is estimated that income from patent licensing has escalated from about US\$ 15 billion in 1900 to over US\$ 100 billion in 1998 (SEFARTI, 2008).

Concerning the impact of the strengthening of patent rights in developing countries, several authors argue that the promises established specially by TRIPs regarding the appeal of foreign investment in $\mathrm{R} \& \mathrm{D}$, the increase in technology transfer and the decrease in catching up with developed nations were not being fulfilled. Chang (2001) highlighted that, while in theory, the strengthening of the patent system can encourage developed countries to transfer technology to developing nations by formal means; in practice there is little evidence of that occurrence.

The frustrated alternative that was the International Code on the Transfer of Technology, initiated in 1976 at the United Nations Conference on Trade and Development (UNCTAD) by deliberation of the United Nations General Assembly in 1974, as a declaration aimed at the establishment of a New World Economic Order would have been a good path to start decreasing disparities between rich and poor countries. Through a supranational set of norms on technology transfer, necessary for the establishment of a New World Technology Order, the discipline of technology trade could have been conducted on more equitable bases, and would discourage the abusive practices that benefit richer countries so. That initiative, however, never did catch up, the reason behind it being the opposition of wealthy countries.

On the contrary, stronger patent rights would decrease the chances of less technologically developed nations of promoting catch up through informal means, via reverse engineering or processes of imitation and adaptation of advanced technologies that may be more important to the promotion of development than formal technology transfer. For the author, in the case of developing countries in which technological assimilation

35 Patent families are a set of patents taken in several countries at a time to protect a single invention, meaning that the initial application in a given country is then extended to other countries' patent offices. 
is more relevant that the generation of state of the art innovation, the benefits of an industrial property regime are minimal.

Aside from the scarce evidence connection the strengthening of patent rights to an increase in $\mathrm{R} \& \mathrm{D}$, the costs of the opportunity to establish and process a strong patent rights system tends to be considerable in developing countries, given the limitations in technical, administrative and human resources.

Taking into consideration that the majority of worldwide patents are from developed countries, royalty expenses usually exceed potential benefits significantly.

To illustrate the matter: the following table issued by the Central Bank of Brazil (Banco Central do Brasil) indicates the flow of capital input and output in the area of copyright between Brazil and the United States. Although the data is not about patents, the numbers show the huge deficit in the trade balance between the two countries in the field of copyright. In 2008, there was an inflow of US\$27,204,000 from Brazilian copyright in the US. The US, however, received US\$2,359,143,000 in copyright royalties from Brazil.

\section{Table 1 Capital Flow between Brazil and the U.S.}

\begin{tabular}{|c|c|c|c|c|c|c|c|c|c|c|c|c|c|c|}
\hline \multicolumn{3}{|c|}{ Revenues coming from the US } & \multirow[b]{2}{*}{1998} & \multirow[b]{2}{*}{1999} & \multirow[b]{2}{*}{2000} & \multirow[b]{2}{*}{2001} & \multirow{2}{*}{2002} & \multirow[b]{2}{*}{2003} & \multirow[b]{2}{*}{2004} & \multirow[b]{2}{*}{2005} & \multirow[b]{2}{*}{2006} & \multirow[b]{2}{*}{2007} & \multirow[b]{2}{*}{2008} & \multirow{2}{*}{$\begin{array}{c}\text { US\$ mil } \\
2009 \\
\end{array}$} \\
\hline & 1996 & 1997 & & & & & & & & & & & & \\
\hline Film renting & 32,7 & 2,5 & & 7,5 & 3,5 & 1,6 & 0,5 & 6,7 & 0,4 & 30,6 & 7,4 & 1,6 & 188,2 & 0,6 \\
\hline $\begin{array}{l}\text { Tapes and recorded } \\
\text { discs renting }\end{array}$ & 0,2 & 37,5 & 42,5 & 183,2 & 455,4 & 187,8 & 197,5 & & & 0,9 & 0,9 & 0,5 & 1,2 & 143,2 \\
\hline Copyrights & 2.141 & 2.356 & 8.152 & 5.418 & 3.199 & 4.226 & 9.475 & 11.370 & 4.489 & 8.107 & 16.630 & 20.101 & 23.166 & 17.837 \\
\hline Software copyrights & 339 & 1.337 & 4.583 & 1.407 & 1.280 & 393 & 1.369 & 1.569 & 256 & 19.706 & & & & \\
\hline $\begin{array}{l}\text { Software acquisitions - } \\
\text { single copy }\end{array}$ & 240 & 1.879 & 910 & 492 & 789 & 1.620 & 2.404 & 3.062 & 10.929 & 1.471 & & & & \\
\hline $\begin{array}{l}\text { International database } \\
\text { use }\end{array}$ & 11 & 1.670 & 342 & 285 & 190 & 15 & 56 & 43 & 5.116 & 2.116 & 13.096 & 1.239 & 1.880 & 1.556 \\
\hline Events broadcasting & 923 & 2.486 & 1.710 & 4.545 & 5.066 & 6.856 & 8.121 & 4.084 & 2.080 & 2.715 & 1.906 & 3.558 & 1.969 & 1.940 \\
\hline Total & 3.687 & 9.769 & 15.738 & 12.338 & 10.984 & 13.301 & 21.623 & 20.135 & 22.870 & 34.147 & 31.641 & 24.899 & 27.204 & 21.477 \\
\hline \multicolumn{15}{|c|}{ Revenues going to the US } \\
\hline & 1996 & 1997 & 1998 & 1999 & 2000 & 2001 & 2002 & 2003 & 2004 & 2005 & 2006 & 2007 & 2008 & 2009 \\
\hline Film renting & 1.132 & 4.637 & 23.022 & 38.296 & 37.355 & 39.860 & 27.143 & 36.435 & 53.716 & 21.372 & 46.587 & 13.119 & 7.115 & 2.504 \\
\hline $\begin{array}{l}\text { Tapes and recorded } \\
\text { discs renting }\end{array}$ & 10 & 2.948 & 4.649 & 14.429 & 11.185 & 17.652 & 39.484 & 40.453 & 50.653 & 55.453 & 71.543 & 72.040 & 69.819 & 56.257 \\
\hline Copyrights & 26.379 & 63.444 & 116.141 & 116.334 & 116.503 & 93.436 & 80.440 & 84.409 & 93.848 & \begin{tabular}{|l|}
183.033 \\
\end{tabular} & 302.983 & 210.149 & 246.643 & 147.750 \\
\hline Software copyrights & 205.259 & 292.645 & 391.199 & 363.084 & 473.726 & 513.596 & 530.341 & 539.380 & 625.963 & 1.001 .420 & 1.215 .987 & 1.468 .616 & 1.665 .625 & 1.018 .373 \\
\hline $\begin{array}{l}\text { Software acquisitions - } \\
\text { single copy }\end{array}$ & 56.429 & 107.263 & 152.809 & 224.111 & 260.713 & 222.238 & 182.579 & 155.441 & 162.901 & 40.163 & & & & \\
\hline $\begin{array}{l}\text { International database } \\
\text { use }\end{array}$ & 1.290 & 4.908 & 5.517 & 6.618 & 14.386 & 15.914 & 24.727 & 27.021 & 22.750 & 29.255 & 37.880 & 51.007 & 61.905 & 44.131 \\
\hline Events broadcasting & \begin{tabular}{|l|}
26.674 \\
\end{tabular} & 49.180 & 124.868 & 128.001 & 128.934 & 119.941 & 107.028 & 111.962 & 112.274 & 132.921 & 178.788 & 219.283 & 308.037 & 209.931 \\
\hline Total & 317.173 & 525.025 & 818.204 & 890.874 & 1.042 .801 & 1.022 .637 & 991.742 & 995.101 & 1.122.105 & 1.463 .617 & \begin{tabular}{|l|}
1.853 .768 \\
\end{tabular} & 2.034 .213 & 2.359 .143 & 1.478 .946 \\
\hline
\end{tabular}

Source: Banco Central do Brasil - DESIG, based on the records of contracted exchange rates by 09/09/2009

The following table, also from the Central Bank of Brazil, illustrates the transfer of several types of knowledge goods including trademarks, copyright, software and patents to foreign countries. 
Table 2 Financial Transfers to Abroad - Contracted Exchange Rates

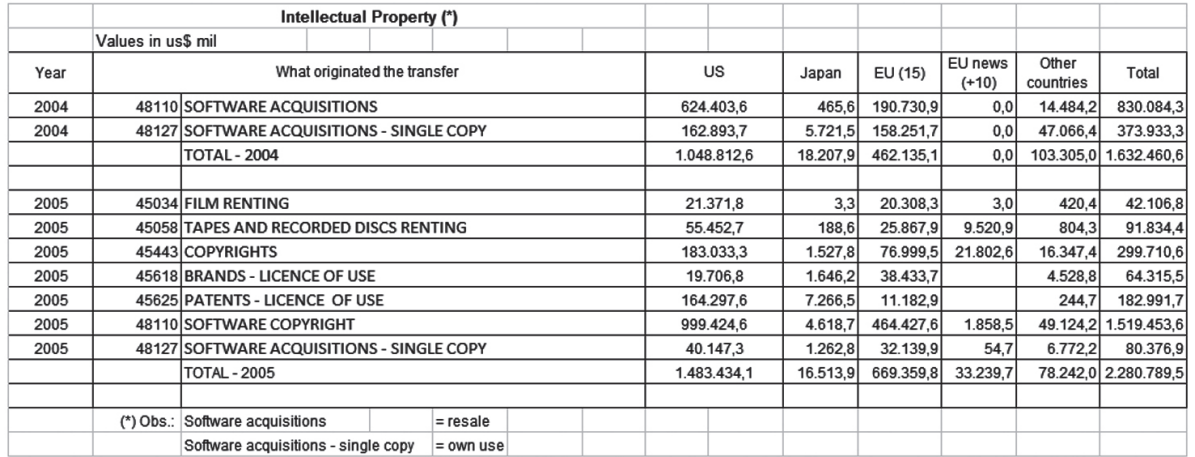

Source: DW Contratos/DECEC/Contratação/Fato Natureza/Software_Marcas_Dir.Aut_Alug Filmes/Fitas_EUA_ JAPÃO_UE_Fato

Chang (2001) also argues that there is little evidence in favor of the connection between the strengthening of intellectual property rights and promotion of foreign direct investment (FDI), as, given that the business has guaranteed protection, the threat of local competitors - that could copy the product and manufacture it for cheap is minimized, inducing market supply through imports, to the clear detriment of the national industry and local training and technology transfer.

\section{WORLD BANK CONCLUDES THAT THERE IS NO SET RELATIONSHIP} BETWEEN FOREIGN DIRECT INVESTMENT AND PATENT PROTECTION

The World Bank, in a 2005 Report, concluded that "[e]vidence is inconclusive about the responsiveness of FDI to intellectual property regimes". ${ }^{36}$

Chang (2001) concludes that developed countries should recognize that, during their development process, they have incurred in practices that are nowadays illegal, such as the violation of patent rights from foreign nations. It would be, therefore, questionable that emerging countries need patent rights regimes that are fundamentally different from those of advanced nations, including shorter patent protection term, more viable compulsory licensing, reduced royalty payments, among others.

Data from the pharmaceutical sector can illustrate the criticism. Evidence speaks against the argument of promotion of innovation through the protection of patent rights. Most "new" products placed in the pharmaceutical market would, in reality, be imitation products (me toos), meaning equivalent molecules to the ones already in the market that do not represent real innovation. 
In fact, a detailed analysis of hundreds of new drugs approved by the FDA between 1989 and 2000 revealed that $75 \%$ do not show therapeutic benefits against other existing products. Only 153 (15\%) out of 1,035 new drugs approved by the FDA in that period were framed as highly innovative - drugs with new active principles that also induced significant clinical improvements. ${ }^{37}$

Between 2000 and 2004, the situation was much the same; only 11\% of new drugs were highly innovative (49 out of 427$)^{38}$. Following that pattern, the scientific magazine British Medical Journal published a study demonstrating that only 68 (5.9\%) out of 1,147 new patented drugs analyzed between 1990 and 2003 by the Canadian agency for price revision of patented drugs were labeled breakthrough drugs - that is, the first pharmaceutical product that effectively treats a given disease or promotes considerable treatment gains in comparison with existing drugs ${ }^{39}$.

More recently, a study developed by Professor Carlos Correa reveals the drop in FDA approval of new chemical entities for pharmaceutical use over the last few years, as demonstrated by the following chart. ${ }^{40}$

\section{Chart $1 \quad$ New chemical entities for pharmaceutical use} approved by the FDA, U.S. (1994-2010)

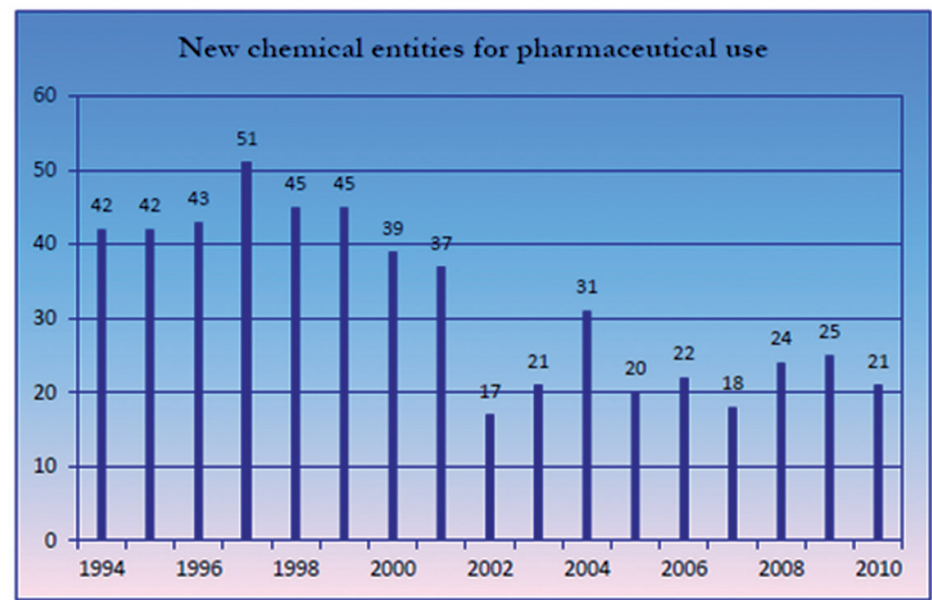

Source: FDA apud CORREA, 2011.

37 See James Love. Evidence Regarding Research and Development Investments in Innovative and Non-Innovative Medicines. September 2003. Available at http://www.cptech.org/ip/health/rnd/ evidenceregardingrnd.pdf.

38 United States Food and Drug Administration - CDER NDAs Approved in Calendar Years 1990-2004 by Therapeutic Potential and Chemical Type. Available at http://www.fda.gov/cder/rdmt/pstable.htm.

39 Breakthrough drugs and growth in expenditure on prescription drugs. In Canada, Morris L. Barer, Patricia A. Caetano and Charlyn D. Black, Steven G. Morgan, Kenneth L. Bassett, James M. Wright, Robert G. Evans, British Medical Journal, 2nd September 2005, 331:815-6. Apud MÉDICOS SEM FRONTEIRAS. As negociações na OMS sobre Saúde Pública, Inovação e Propriedade Intelectual (IGWG): o que vem acontecendo e quais são os desafios? (in Portuguese).

40 Correa, Carlos. Pharmaceutical Innovation, Incremental Patenting and Compulsory Licensing. Geneva, South Center, 2011. 
The European Commission, executive branch of the European Union, issued a report in 2008 demonstrating a decrease in new chemical entities registered between 1990

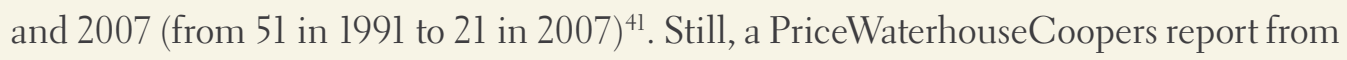
2007 reveals that, in spite of the increased expenditure with research and development, the FDA approved only 22 new molecular entities in 2006.

\section{PRICEWATERHOUSECOOPERS ALERTS: PHARMACEUTICAL INDUSTRIES DO NOT INNOVATE IN NEGLECTED AREAS}

The central problem of the pharmaceutical industry is the lack of innovation in treatments for world medical needs that are yet to be addressed. ${ }^{42}$

The data suggests that the present patent system, instead of stimulating innovation, is promoting investment in existing products or processes that generate patents with guaranteed payback for its holders ${ }^{43}$, but little actual benefit for society.

That practice is called evergreening, that is, an abusive perennialization or postponement characterized by varied strategies employed by patent holders to extend their monopolies beyond the 20 years of protection, even in the absence of any additional benefit to society. These measures are aimed chiefly at delaying the competitor's entry in the market ${ }^{44}$.

\section{WORLD BANK: \\ PRODUCTION OF PATENTED PHARMACEUTICALS \\ HAPPENING OUTSIDE DEVELOPING COUNTRIES IN SPITE OF PATENTS GRANTED IN THOSE COUNTRIES}

Patent protection drove several multinational pharmaceutical companies to stop or refrain to start production and investment in developing countries and instead supply these markets with products from the North. ${ }^{45}$

41 EUROPEAN COMMISSION DG. Pharmaceutical Sector Inquiry: preliminary report, November, 2008.

42 PRICEWATERHOUSECOOPERS, Pharma 2020: the vision. Which path Will you take? Available at http:// www.pwc.com/gx/eng/about/ind/pharma/pharma2020final.pdf. Acesso em 09 jul. 2008.

43 CORREA, Carlos Maria. Tendencias en el Patentamiento Farmacéutico: estudios de casos. Buenos Aires: Corregidor, 2001.

44 Measures such as this were found even in the United States, in a 2002 report by the Federal Trade Commission - FTC de 2002. Generic drug entry prior to patent expiration: an FTC study. Washington, DC, United States Federal Trade Commission, July 2002.

45 WORLD BANK, Global Economic Prospects 2005, op. cit. Apud JAGUARIBE, Roberto et al. Propriedade intelectual: espaços (...), op cit. p. 292. 
That is exactly the contrary of what was defended by rich countries when the present international patent system was negotiated.

Patent rights is not the only mechanism to generate revenue derived from innovation. A perfected national legislation should distinguish patent rights from additional means of protection in fields other than the criminal one, such as, for instance, those against unfair competition, which are not to be confused with patents, despite their residually wider peripheral protection. Empirical studies reveal that patenting propensity rates and their role in stimulating R\&D vary among sectors. Patents in the chemical and pharmaceutical industries, for instance, would be more relevant to sustain the elevated costs with R\&D needed for innovation.

As for cases in which sequential innovation is an integral part of the innovative process, such as, among others, the software industry, patents may have the opposite effect, hindering innovation and limiting user's choices, besides raising the price of the final product.

Even without using formal appropriation mechanisms, the innovator can make use of other mechanisms to recover his or her investments. Among other forms of incentive are trade secrets, time advantage and additional capabilities. Outside of the patent field itself, a legislation regarding unfair competition could be created to cover what does not fall under patent protection.

Cimoli and Primi (2008) highlight that trade secret and time advantage are the most used protection mechanisms, while patents play a relatively more important role in the strategies of larger scale businesses.

Arundel (2001) reveals that the probability of businesses giving preference to secret over patents as a way of retaining exclusivity decreases as the business grows, in the case of product inventions. Chang (2001) argues that, when the inventor trusts the possibility of keeping a secret, he will opt for that mechanism and will not file a patent. By this logic, the patent system would not be employed, in order to prevent the publicizing of descriptions of inventions (one of the patentability requirements), keeping the secret instead.

The above exposition makes it clear that patent rights can strongly influence the economic, social and technological development of a country, both in the sense of promoting sovereignty and national independence, as well as in the opposite sense, by means of technological dependency from other countries. That is why the adopted public policies should be carefully balanced: they should promote innovation and a just and equitable financial compensation to innovators, aiming at technological, scientific, economic and social development. 


\subsection{The Brazilian case and its technological innovation indicators}

Patents, in particular its relationship with the economic transformations associated to the dynamism of the technology-intensive new sectors and to the new international division of production and trade, was the subject of extensive debates during the 1990's. At that time, much like other developing countries, Brazil was strongly pressured to amend its legal and institutional basis for incentives to innovation by means of patent rights. In that context, after a series of discussions being held since the late 1980's, Law no. 9279/96, the Patent Act, passed and came into force in 1997.

The Patent Act was adopted soon after the TRIPs Agreement was signed in 1994 by all Member Countries of the then recently created World Trade Organization. In spite of the agreement's grant of a 5-year transition period until it would become mandatory for developing countries, Brazil declined that safeguard, hoping to enjoy the benefits expected from a more austere patent system sooner. ${ }^{46}$

Those who sided with the adoption of a more strict patent rights legislation argued that its implementation would be a modernization opportunity for Brazil, by strengthening quality standards and the competitive capability of the local industry, elevating the flow of technology transfer by means of a growing number of licensing contracts and stimulating foreign direct investment, local patenting, local production, and investments in R\&D by foreign businesses.

Those arguments were backed by strong pressure from technologically advanced countries, the United States in particular, which increasingly incited its trade partners to adopt more austere attitudes in the patent and related rights field, at the risk of trade sanctions. ${ }^{47}$

The present Brazilian Patent Act was approved under harsh criticism from some national industries.

46 See Articles 65(1) and (2) of TRIPs.

47 See Peter Drahos, with John Braithwaite, Information Feudalism: who owns the knowledge economy?, The New Press, New York, 2003. 


\section{BRAZILIAN LABORATORIES TRIED TO WARN ABOUT SERIOUS ISSUES INVOLVING THE PATENT ACT WHEN IT WAS UNDER NEGOTIATION IN THE 1990'S}

According to Carlos Alexandre Geyer, President of the Association of National Pharmaceutical Industries (Alanac), during the negotiations that took place in the 1990s on the present Patent Act, associations representing the Brazilian pharmaceutical industry such as the Brazilian Association of Chemical and Biotechnology Industries and its Specialties (Associação Brasileira das Indústrias de Química Fina, Biotecnologia e suas Especialidades - Abifina) and Alanac tried to "convince society and the congresspersons that what they were going to approve, mainly due to a demand by the United States, would certainly bring trouble in the future for our [Brazilian] industry (...). We've had some success in the Chamber of Deputies but, when the project reached the Senate, it was completely amended under pressure to fulfill demands mainly from the United States (...). We, as opposite to, for instance, Argentina, and presently India, did not take advantage of the safeguards allowed by international legislations. (...) In some ways, the present Patent Act in Brazil is even more rigorous that the United States' legislation (...). Unfortunately, our pharmaceutical industry has been trashed. (...) The great majority of congressional representatives who voted for the present patent legislation was not aware of its fundamental objectives, of which they were voting for. Nowadays I believe that society has evolved in that regard, outside of the pressures we feel from other industry sectors, from other exporting industries in Brazil. In the State of Rio Grande do Sul, in spite of the good intentions from the directors of the Federation of Industries of the State of Rio Grande do Sul (Federação das Indústrias do Estado do Rio Grande do Sul - Fiergs) and in spite of the fact that the then president of FIERGS was from the pharmaceutical industry, we could not get enough support to our struggle, to our claim for a suitable patent legislation, because the leather and footwear sector, which is extremely strong in Brazil, was under a threat from the government of the United States that they would cease to import Brazilian shoes. (...) The Brazilian society was used, industrial sectors, exporters at that time, were used as pressure tools for this patent legislation to get approval." ${ }^{48}$

As a result of the sanction of the present Patent Act, a clear drop can be observed, from 1996 to 1997, in the participation of "residents" in patent filing, which went from 32.4\%

48 See comments by Carlos Alexandre Geyer, President of Alanac (National Pharmaceutical Laboratories Association) during the roundtable "Harmonização internacional: o futuro do tratado substantivo da Lei de Patentes e suas implicações para os países em desenvolvimento" (in Portuguese), from the Patents, Innovation and Development International Seminar (Seminário Internacional Patentes, Inovação e Desenvolvimento - SIPID), held by Abifina (Brazilian Association of Chemical and Biotechnology Industries and its Specialties) in 5 and 6 July 2007, in Rio de Janeiro, available at http://www.abifina.org.br/arquivos/ II_sipid_3_hormonizacao.pdf. 
to $17 \%$. In total, including "residents" and "non-residents", patents filed in Brazil went from 8,057 in $1996^{49}$ to 16,235 in 1997, reaching 21,825 filings in 2007 (OMPI, 2012).

In Brazil, part of the increase of patent applications from "non-residents" is associated with, among other factors, the revalidation of foreign patents, known as pipeline, a mechanism through which a patent granted abroad is valid in Brazil during its original country term - as discussed in Chapter 6.

\section{STATISTICS EVIDENCE THAT THE PRESENT PATENT SYSTEM HAS BEEN MORE BENEFICIAL TO FOREIGNERS}

After the Patent Act came into force in 1997, the participation of "non-residents" has increased and remained around $75-80 \%$ of the patent filings in Brazil (Table 1), which shows, among other things, that the costs of maintenance of the patent system in Brazil is being directed, as a priority, to the protection of foreign, instead of national, patents.

It is important to highlight that foreign companies with legally established offices in Brazil are included in the concept of the expression "residents". Therefore, "resident" does not refer to the national industry, but to the sum of national businesses and foreign businesses with legally established branches in Brazil.

A research conducted by Reis (2012) evidences that "six countries dominate $90.5 \%$ of the total patent filings for antiretroviral medicines in Brazil, with companies from the United States being the chief patent holders, with $62 \%$ of patents. Brazil corresponds for $2.3 \%$ of the filings." 50

The predominance of "non-residents" as patent applicants is not particular to Brazil, as it is a reality in most emerging countries. China is an exception to the phenomenon: since 2004, residents have been responsible for the majority part of patent filings before the Chinese Patent Office, and in 2009 they have reached $72.8 \%$ of that total.

In that regard, the Chinese patent act has undergone through profound reforms in 2008, as a way of encouraging sequential innovation and the local industry in search for the country's technological and economic development.

49 Yearly average of 7,087 patents filed between 1990 and 1996.

50 See Renata REIS, Panorama Patentário dos Medicamentos Antirretrovirais no Brasil. Ongoing doctoral thesis from the Graduate Program in Public Policies, Strategies and Development of the Institute of Economy, Federal University of Rio de Janeiro, 2012. 
Table 3 Patent applications in Brazil: residents and non-residents - 1998 to $2011^{51}$

\begin{tabular}{|c|c|c|c|c|c|c|c|c|c|c|c|c|c|c|}
\hline \multicolumn{15}{|l|}{ PATENT FILINGS } \\
\hline $\begin{array}{c}\text { Types of Patents } \\
\text { and Depositor } \\
\text { Origin }\end{array}$ & 1998 & 1999 & 2000 & 2001 & 2002 & 2003 & 2004 & 2005 & 2006 & 2007 & 2008 & 2009 & 2010 & 2011 \\
\hline Total & 14.970 & 19.640 & 20.783 & 21.618 & 20.230 & 20.093 & 20.422 & 21.847 & 23.179 & 24.915 & 26.841 & 25.956 & 28.141 & 31.765 \\
\hline residents & 4.737 & 6.157 & 6.515 & 7.061 & 6.955 & 7.478 & 7.690 & 7.339 & 7.214 & 7.373 & 7.873 & 7.766 & 7.286 & 7.764 \\
\hline non-residents & 10.223 & 13.483 & 14.268 & 14.557 & 13.275 & 12.615 & 12.732 & 14.508 & 15.965 & 17.542 & 18.968 & 18.190 & 20.855 & 24.001 \\
\hline Invention & 5.598 & 6.743 & 6.866 & 6.808 & 5.875 & 5.997 & 6.408 & 6.484 & 6.205 & 6.448 & 6.421 & 6.259 & 6.316 & 7.419 \\
\hline residents & 2.234 & 2.821 & 3.216 & 3.490 & 3.400 & 3.808 & 4.031 & 4.035 & 3.949 & 4.198 & 4.344 & 4.229 & 4.204 & 4.718 \\
\hline non-residents & 3.364 & 3.922 & 3.650 & 3.318 & 2.475 & 2.189 & 2.377 & 2.449 & 2.256 & 2.250 & 2.077 & 2.030 & 2.112 & 2.701 \\
\hline Utility Model & 2.497 & 3.326 & 3.279 & 3.553 & 3.489 & 3.588 & 3.573 & 3.210 & 3.180 & 3.049 & 3.440 & 3.383 & 2.989 & 3.005 \\
\hline residents & 2.422 & 3.257 & 3.197 & 3.461 & 3.438 & 3.539 & 3.525 & 3.159 & 3.126 & 3.011 & 3.385 & 3.353 & 2.920 & 2.905 \\
\hline non-residents & 75 & 69 & 82 & 92 & 51 & 49 & 48 & 51 & 54 & 38 & 55 & 30 & 69 & 100 \\
\hline $\begin{array}{l}\text { Certification of } \\
\text { Addition }\end{array}$ & 67 & 74 & 76 & 87 & 106 & 121 & 122 & 126 & 123 & 142 & 127 & 124 & 104 & 74 \\
\hline residents & 62 & 64 & 69 & 79 & 100 & 114 & 115 & 120 & 116 & 128 & 114 & 115 & 100 & 70 \\
\hline non-residents & 5 & 10 & 7 & 8 & 6 & 7 & 7 & 6 & 7 & 14 & 13 & 9 & 4 & 4 \\
\hline PCT & 6.808 & 9.497 & 10.562 & 11.170 & 10.760 & 10.387 & 10.319 & 12.027 & 13.671 & 15.276 & 16.853 & 16.190 & 18.732 & 21.267 \\
\hline residents & 19 & 15 & 33 & 31 & 17 & 17 & 19 & 25 & 23 & 36 & 30 & 69 & 62 & 71 \\
\hline non-residents & 6.789 & 9.482 & 10.529 & 11.139 & 10.743 & 10.370 & 10.300 & 12.002 & 13.648 & 15.240 & 16.823 & 16.121 & 18.670 & 21.196 \\
\hline
\end{tabular}

Source: the Brazilian Patent Office. Note: the concept of "residents" includes foreign industries with legally established office in Brazil. Therefore, the expression "resident" does not indicate Brazilian industry, but the sum of national businesses with foreign companies with legally established branches in Brazil.

The marked growth in royalties and licenses ${ }^{52}$ in the 1990's is directly connected to foreign outflow. This tendency can be traced back to 1993, shortly before the Patent Act came into force, and continued to grow throughout the following years.

In this context, the annotation of technology contracts, as well as precise examination of eventual restrictive clauses, including those damaging to competition, which can be harmful for the development of Brazil or to the activities of the company or institution, public or private, purchasing the technology, is clearly of great importance. Public policies should contemplate adequate regulation of technology transfer by the government, preventing the implementation of restrictive or abusive conditions in the country, such as: restriction to exports, research restrictions, restriction to the negotiation of competitive technology, restriction to the questioning of patents or licensed rights, price, quantity or sale restrictions, and clauses imposing inadequate appropriation of research results by the company that purchased foreign technology (FURTADO, 2011).

51 Including applications made under the Patent Cooperation Treaty - PCT.

52 According to the definition by the Central Bank of Brazil (Banco Central do Brasil), the series "royalties and licenses" records revenue and expenses stemming from the use of intangible assets and intellectual property rights such as patent exploration license, use of brand names license, technology supply, technical assistance services, franchises and copyright. It also includes additional revenue and expenses concerning the registration, filing or maintenance of brand names and patents. 


\section{THE PATENT SYSTEM IS BEING USED AS A MECHANISM OF TRANSFER OF RESOURCES FROM LESS TECHNOLOGICALLY DEVELOPED COUNTRIES TO WEALTHY COUNTRIES}

In 1993, the Brazilian deficit in intellectual property rights reached US\$ 86 million. In 2012, after the creation of the WTO and after the Patent Act came into force, this sum reached US\$ 3.1 billion, according to data from the Central Bank of Brazil - which indicates losses of over 3,600\% (three thousand and six hundred per cent).

This data suggests that the intellectual property rights regime is functioning as a mechanism of income transfer from developing and least developed countries to economically central countries, in the opposite flow than the stipulated by its goals and by the reasoning used by more technologically developed countries during the TRIPs negotiations at the WTO.

In the words of Joseph Stiglitz, Nobel Prize laureate in economics, "the patent system is a distortionary and, with the huge transfers that might result from the poor countries to the rich, a potentially inequitable system of funding research. The huge transfers clearly can have an adverse effect on development." ${ }^{13}$

It is important to note that the deficit in the intellectual property trade balance started growing exactly around 1995, the year that the WTO entered into force. And the trade balance in the sector began to experience a huge downfall after the present Patent Act came into force - as well as the present Copyright (no. 9.610/98) and Software (no. 9.609/98) Acts.

Another relevant fact concerns the evolution of Brazilian patent filings in the world ${ }^{54}$.

\section{BRAZIL HOLDS LESS THAN $0.3 \%$ OF PATENT APPLICATIONS IN THE WORLD}

After ten years from the introduction of the Patent Act, there has not been an evolution of the Brazilian participation in the world scenario regarding patent filings. The participation of Brazilian filings regarding the world total has remained at $0.28 \%$, which means less than 0.5 per cent. ${ }^{55}$ That figure remains the same.

53 STIGLITZ, Joseph E. Towards a pro-development and balanced intellectual property regime. WIPO: Seoul, 2004. p. 10.

54 Brazilian filings are those indicating Brazil as the residency of the first applicant, including patents filed in the Brazilian office or other foreign offices.

55 Considering Brazilian filings in national and international offices, against the total world filings. The average was $0.39 \%$, including filings from Brazilian residents (which comprise foreign businesses with legally established branches in Brazil) against total filings from residents in the world between 1997 and 2007. 
Graph 2 Brazilian patent filings/World patent filings - 1997 to 2007

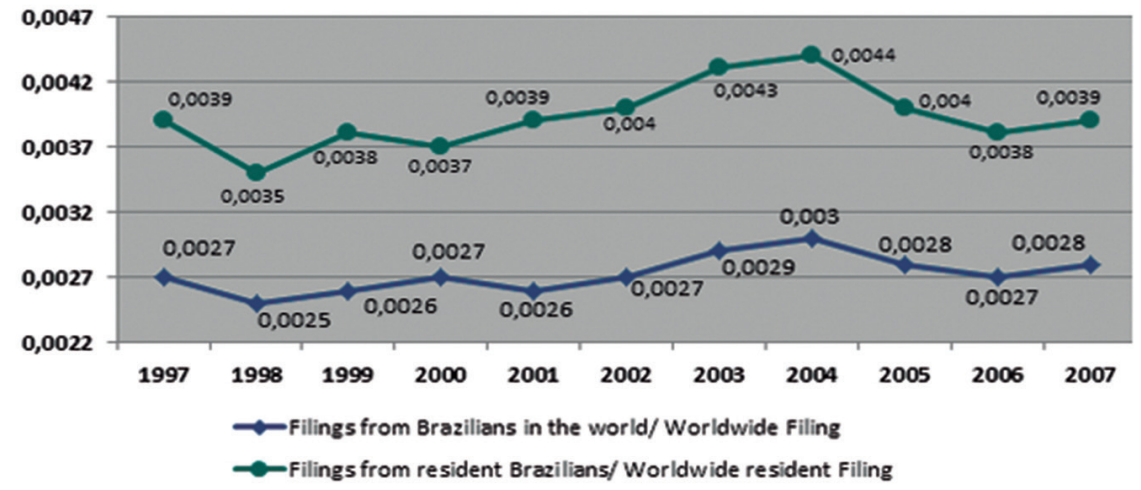

Source: OMPI. Own elaboration.

\section{FOREIGNERS HAVE BENEFITED MORE FROM THE PATENT SYSTEM IN THE PHARMACEUTICAL FIELD THAN THE NATIONAL INDUSTRY}

Regarding the predominant "non-resident" patent filings, the pharmaceutical field is emblematic. According to Correa (2011), a survey conducted in Brazil yielded particularly surprising results regarding domestic patent granting, given the existence of an R\&D structure in the country. ${ }^{56}$

Among the 278 pharmaceutical patents granted by the Brazilian Patent Office between 2003 and 2008 identified by the above-mentioned study, only one is held by a Brazilian. 
Graph 3 Patents granted in Brazil in the pharmaceutical sector by country originating the application - 2003-2008

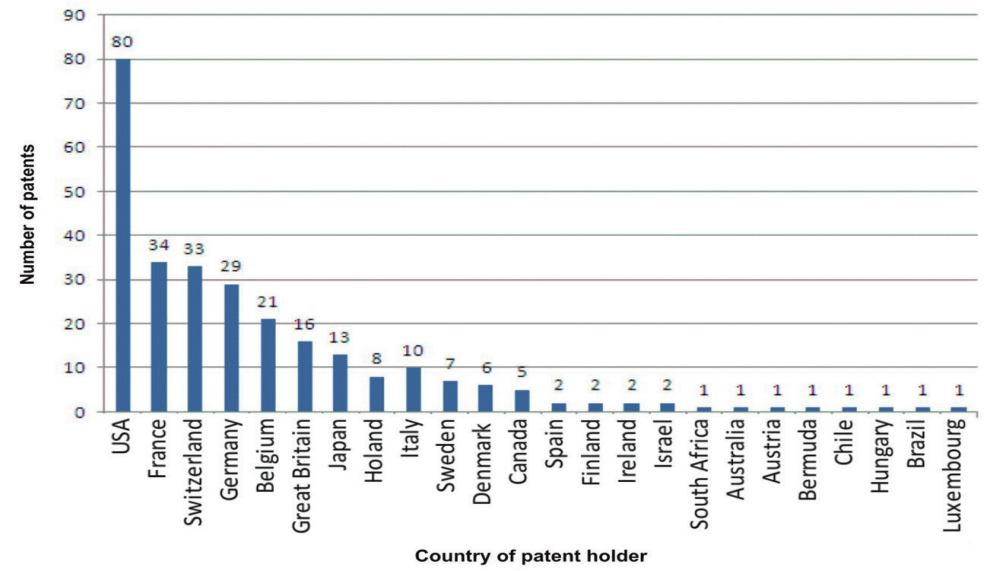

Source: Carlos M. Correa, Pharmaceutical Innovation, Incremental Patenting and Compulsory Licensing, 2011.

Contrary to what the technologically developed countries promised, since the adoption of the TRIPs Agreement in Brazil there was not a larger number of patent filings by nationals or even foreigners residing in the country; an indication that there was no technology transfer, whether by means of foreign direct investment or diffusion of technology supposedly promoted by the patent regime.

Going further in the matter of attracting foreign direct investment as a consequence of more protection of patent rights, which would promote more economic development for developing and least developed countries, evidence also shows that it is not the case for many sectors.

\section{FOREIGN INVESTMENT DROPPED AFTER THE TRIPS AGREEMENT ENTERED INTO FORCE}

In Brazil, data from the United Nations Industrial Development Organization (UNIDO) evidences that investments in the biotechnology field dropped from US\$ 28 million in 1994 to US\$ 15 million in 2003. In the pharmaceutical sector, investment dropped from US\$ 91 million in 1994 to US\$ 37 million in $2003^{57}$.

Thus, the grant of patents in the fields of biotechnology and medicines in Brazil led, against expectations, to a drop in foreign investments, contradicting the goals promised during the negotiation of the TRIPs Agreement and the elaboration of the present Patent Act.

57 UNIDO, Indstat 4, 2005. Apud JAGUARIBE, Roberto and BRANDELLI, Otávio. Propriedade intelectual: espaços (...), op cit. p. 295. 
Regarding the pharmaceutical sector in Brazil, a study conducted by the Oswaldo Cruz Foundation (FIOCRUZ) ${ }^{58}$ analyzed the technology transfer contracts in the field for two periods (1992 and 2001): five years before and five years after the present Patent Act entered into force. The contracts were divided into the categories "license for trademark use" (BNU), "franchise" (FRA), "technology supply" (TS), "license for patent exploration" (PE), "cost-sharing in research and development" (R\&D) and "technical assistance" (TAS).

\section{TECHNOLOGY TRANSFER CONTRACTS IN THE PHARMACEUTICAL FIELD DROPPED BY ALMOST 70\% AFTER TRIPs ENTERED INTO FORCE}

FIOCRUZ evidences that there was an almost $70 \%$ decrease in the number of technology transfer contracts in the pharmaceutical field, dropping from 110 in 1992 to 34 in $2001 .{ }^{59}$

Most of those contracts refer only to "trademark use" and "technical assistance", that, in practice, does not substantially contribute to an increase or improvement in local technological development.

\section{MINISTRY OF DEVELOPMENT \& INDUSTRY SAYS THAT IMPORTS IN THE PHARMACEUTICAL SECTOR HAVE SUBSTANTIALLY INCREASED AFTER TRIPs}

The Ministry of Development, Industry and Foreign Trade (Ministério do Desenvolvimento, Indústria e Comércio Exterior - MDIC) evidences that imports have increased exponentially after the WTO and the Patent Act entered into force, and that the Brazilian trade balance in the pharmaceutical sector is substantially negative, that is, the number of imports is larger than the number of exports, as demonstrated in the following graph:

58 See Oliveira, M.A.; Bermudez, J.A.Z.; Chaves, G.C. et al., 2004. Pharmaceutical patent protection in Brazil: who is benefiting? In: Bermudez, J.A.Z.; Oliveira, M.A. (Org.). Intellectual Property in the context of the WTO TRIPs Agreement: Challenges for public health, pp. 161-175, Rio de Janeiro: ENSP/FIOCRUZ.

59 See OLIVEIRA, M.A.; BERMUDEZ, J.A.Z.; CHAVES, G.C. et al., op. cit. 
Graph 4 Brazilian trade balance in the pharmaceutical sector, 1996-2010

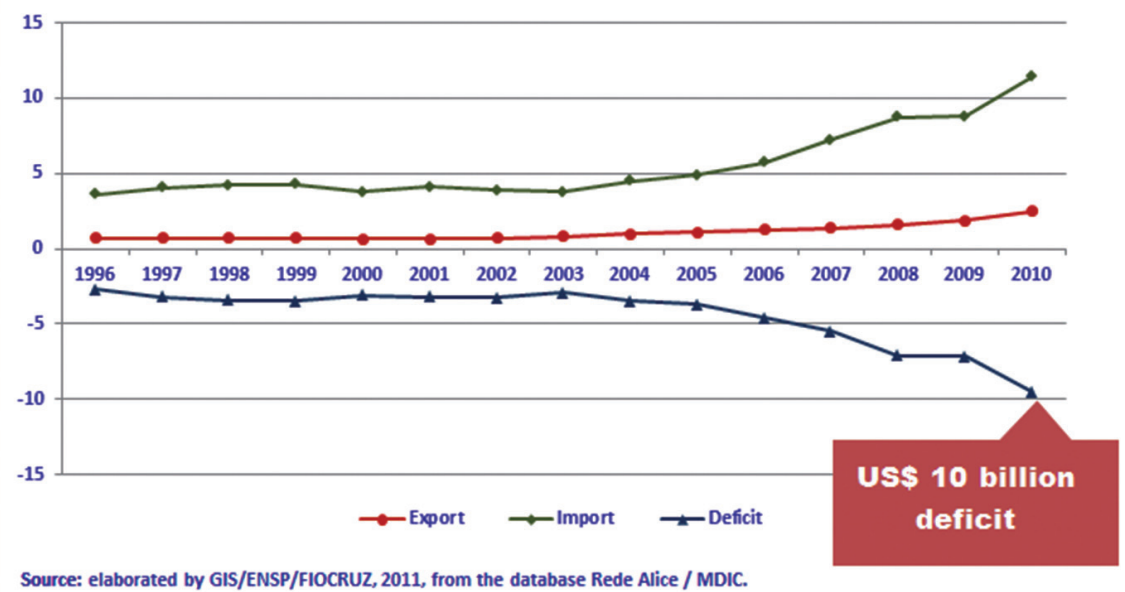

The graph evidences that in the pharmaceutical field in Brazil patent rights were responsible for a strong decrease in technology transfer contracts, operating as a mechanism of market reserve by means of strengthening trademarked products developed abroad, as shown by the study coordinated by the Oswaldo Cruz Foundation and by data from the Brazilian trade balance.

Thus, according to Mr. Otávio Brandelli, from the Ministry of Foreign Affairs (Ministério das Relações Exteriores - MRE):

Considering balance of payments, trade, market participation by national companies, investments, RGD and RGD vs GDP, after the approval of the industrial property act reform in the 1990's, all those factors are showing either negative or stable performance, which means that the implementation of TRIPs did not bring about the desired or expected results. ${ }^{60}$

Joseph Stiglitz, Nobel Prize laureate of economics, is clear:

(...) intellectual property rights represent a transfer; the holder of the intellectual property right is better off, and the user is worse off. To be sure, advocates of intellectual property rights try to claim that in the long run everyone is better off, but such a claim has never been substantiated. ${ }^{61}$

There are, thus, several suggestions that the patent system presently in force has not been able to reach the goals for which it was instated. There is no evidence proving that

60 International Seminar: 200 anos de Propriedade Intelectual no Brasil. A propriedade intelectual como instrumento de política industrial: lições e desafios. Ministério das Relações Exteriores. Brasília, 29 and 30 April 2009.

61 STIGLITZ, Joseph E. Towards (...). Op cit. p. 15. 
there has been an increase of innovation in developing and least developed countries, whether by means of technology transfer and local production or of an increase in foreign direct investment in the country.

The promotion of innovation has been negatively influenced even in developed countries, as shown by studies on the low quality of patents granted.

In other words, neither the promotion of innovation nor economic and technological development have stemmed from the tightening of intellectual property rights which took place in the mid-1990's.

Facts and evidence have not been supportive of the patent system as we know it. There is a need for re-thinking and renovating the patent regime so that its goals can be reached: innovation and technology transfer aimed at economic, social and technological development.

\subsection{The human right to health and the impact of patents}

The negative impact that the system of intellectual property rights has been making on the access to products or processes protected by patents is notorious. This issue is especially serious in regard to the enjoyment of fundamental rights such as culture, education and health, for instance. We will proceed to briefly approach this matter, with a special focus on the case of the human right to health, which is especially emblematic in this debate.

The right to health is internationally recognized as a fundamental right of every human being. With the constitution of the World Health Organization (WHO) in 1946, health began to be seen as a "state of complete physical, mental and social well-being", and "the enjoyment of the highest attainable standard of health" became "one of the fundamental rights of every human being" ${ }^{62}$.

The leading international human rights treaties, all signed by Brazil, establish the right to health as a fundamental human right. Among them, the UN's Universal Declaration of Human Rights ("Article 25. Everyone has the right to a standard of living adequate for the health and well-being of himself and of his family"), the OAS's 1948 American Declaration of the Rights and Duties of Man ("Article 11. Every person has the right to the preservation of his health through sanitary and social measures relating to food, clothing, housing and medical care, to the extent permitted by public and community resources.") and the UN's International Covenant on Economic, Social and Cultural 
Rights ("Article 12. 1. The States Parties to the present Covenant recognize the right of everyone to the enjoyment of the highest attainable standard of physical and mental health.”), which has cogent force.

On 24 April 2001, the 57th Session of the UN Human Rights Commission approved Resolution 33/2001 proposed by the Brazilian delegation, which categorized access to essential medicines as a human right to health (Horta, 2001). According to this Resolution, Member Countries of the United Nations must adopt legislation to safeguard access to pharmaceutical products from limitations imposed by third parties (The Associated Press, 2001).

The UN Commission on Economic, Social and Cultural Rights declared in 2001 that "any intellectual property regime that makes it more difficult for a State party to comply with its core obligations in relation to health, food, education, especially, or any other right set out in the Covenant, is inconsistent with the legally binding obligations of the State party."63

Within the scope of the UN Human Rights Council, which replaced the Commission in 2006, Brazil approved Resolution 6/29 in 2 October 2009, with their partners in the IndiaBrazil-South Africa Dialogue Forum (IBAS) and with the support of several developing countries, which "recognizes that access to medicines is a fundamental element for achieving progressively the full realization of the right to the full enjoyment of the highest attainable standard of physical and mental health "and" emphasizes the responsibility of States to ensure access for all, without discrimination, to drugs, in particular the essential medicines that are affordable, safe, effective and of good quality". ${ }^{64}$

In Brazil, the right to health has been elevated to the category of fundamental right with the promulgation of the Brazilian Constitution in 1988 (Article 6 65), being defined as a

63 UNITED NATIONS. SUBSTANTIVE ISSUES ARISING IN THE IMPLEMENTATION OF THE INTERNATIONAL COVENANT ON ECONOMIC, SOCIAL AND CULTURAL RIGHTS. Follow-up to the day of general discussion on article 15.1 (c), Monday, 26 November 2001. Human rights and intellectual property. Statement by the Committee on Economic Social and Cultural Rights. E/C.12/2001/15, par. 12. Available at http://www. unhchr.ch/tbs/doc.nsf/0/1e1f4514f8512432c1256ba6003b2cc6/\$FILE/G0146641.pdf.

64 United Nations. General Assembly. Human Rights Council. Resolution 12/24. Access to medicine in the context of the right of everyone to the enjoyment of the highest attainable standard of physical and mental health. A/HRC/RES/12/24. Paragraph 1. (2009).

65 Brazilian Constitution, Article 6: Education, health, food, work, housing, leisure, security, social security, protection of motherhood and childhood, and assistance to the destitute are social rights, as set forth by this Constitution. (See Constitution of the Federative Republic of Brazil, Available at http://www2.camara. leg.br/atividade-legislativa/legislacao/Constituicoes_Brasileiras/constituicao1988.html) 
supreme value of society ${ }^{66}$. Moreover, the right to health is an essential condition for the fulfillment of the constitutional principle of the dignity of the human person (Article 1 , $\mathrm{III}^{67}$ ), and is intrinsically connected to the right to life (Article $5^{68}$ ).

Characterized as an essential right to the full realization of life and dignity, the Brazilian Constitution established the right to health as a right for all and as a State duty, as ruled in Article 196 ${ }^{69}$. Thus, the right to health is an individual right while it is simultaneously a general right, and both are inter-crossed in affirming the need for a State tutelage.

With a view to the promotion of health, the Brazilian Constitution established a national system ruled by the guideline of integral care, guaranteeing the citizens' access to adequate medical treatment, including medicines, as set forth in Article $198^{70}$. This article's guidelines were regulated through Law no. 8080/90, known as Health Act (Lei Orgânica da Saúde), which established the conditions for the creation of the National Health System (Sistema Único de Saúde - SUS). Law no. 8080/90 provides in its Article 6 that, among the SUS actions, is the guarantee of "integral therapeutic care, pharmaceutical included".

In that regard, Brazil's Supreme Court (Supremo Tribunal Federal - STF) consolidated the understanding that, as the corollary of Articles 196 and 198 of the Constitution, it is given to all individuals to demand that the State provides the necessary means of fulfillment of the fundamental right to health, such as the realization of certain surgical procedures and the supply of indispensable medicines for their treatment. ${ }^{71}$.

For millions all over the world, notwithstanding the national and international normative provisions, the full fruition of the right to health remains a distant ideal and

66 BRAZILIAN CONSTITUTION, Preamble: We, the representatives of the Brazilian People, convened in the National Constituent Assembly to institute a democratic state for the purpose of ensuring the exercise of social and individual rights, liberty, security, well-being, development, equality and justice as supreme values of a fraternal, pluralist and unprejudiced society, founded on social harmony and committed, in the internal and international orders, to the peaceful settlement of disputes, promulgate, under the protection of God, this Constitution of the Federative Republic of Brazil.

67 BRAZILIAN CONSTITUTION, Article 1: The Federative Republic of Brazil, formed by the indissoluble union of the states and municipalities and of the Federal District, is a legal democratic state and is founded on: III - the dignity of the human person.

68 BRAZILIAN CONSTITUTION, Article 5: All persons are equal before the law, without any distinction whatsoever, Brazilians and foreigners residing in the country being ensured of inviolability of the right to life, to liberty, to equality, to security and to property, on the following terms: (...).

69 BRAZILIAN CONSTITUTION, Article 196: Health is a right of all and a duty of the State and shall be guaranteed by means of social and economic policies aimed at reducing the risk of illness and other hazards and at the universal and equal access to actions and services for its promotion, protection and recovery.

70 BRAZILIAN CONSTITUTION, Article 198: Health actions and public services integrate a regionalized and hierarchical network and constitute a single system, organized according to the following directives: I decentralization, with a single management in each sphere of government; II - full service, priority being given to preventive activities, without prejudice to assistance services; III - participation of the community.

71 Brazilian Supreme Court, RE 271286 AgR, Rapporteur: Min. CELSO DE MELLO, Second Panel, tried in 12 September 2000, DJ 24-11-2000 PP-00101. 
an expressive number of people remains without access to medicines that could save millions of lives every year, as evidenced by the United Nations. ${ }^{72}$

In regard to medicines, according to data from the World Health Organization $(\mathrm{WHO})^{73}$, there has been over the last few years a worldwide rising tendency in the costs with public health systems caused by increasing medicine prices, which has been affecting chiefly developing and least developed countries.

This tendency can be linked to several factors, one of which being the impact of intellectual property regulation over prices, as they exclude competition among technology providers during the patent's term - as is the case with medicines.

Indeed, several studies evidence that there is a drastic drop in the price of medicines as soon as the patented object expires, due to competition from generic drugs that become available in the market ${ }^{74}$.

A wide-ranging study conducted by the Government of the United States has ascertained that, on average, the prices of generic medicines corresponds to $43 \%$ of the price of the reference drug in force during its patent term. ${ }^{75}$

\section{COMPETITION WITH GENERIC MEDICINES FORCES AIDS DRUG PRICES TO DROP FROM US\$10,439 TO US\$ 67}

In the case of AIDS treatment, due to competition from generic medicines, the price of the first line triple therapy (estavudine, lamivudine and nevirapine) dropped from US\$10,439.00 per patient per year in 2000 (lower original price) to US\$ 67 per patient per year (lower international price - generic Aurobindo, Matrix and Cipla) in 2010.76

That means a reduction of $99 \%$ in treatment cost, possibly because those medicines are not protected by patents in certain countries, which allowed local pharmaceutical companies to manufacture generic versions.

72 UNITED NATIONS. General Assembly. Human Rights Council. Resolution 12/24. Access to medicine in the context of the right of everyone to the enjoyment of the highest attainable standard of physical and mental health. A/HRC/RES/12/24. (2009).

73 OLIVEIRA, Maria Auxiliadora et al. Has the implementation of the TRIPs Agreement in Latin America and the Caribbean produced intellectual property legislation that favours public health?, Bulletin of the World Health Organization, 2004;82:815-821.

74 See, among others, Integrating intellectual property rights and developing policy. Report of the Commission on intellectual property rights, London, 2002, especially pages 29-56.

75 REIFFEN, D. e WARD, M. Generic drug industry dynamics. US Federal Trade Commission Working Paper $248,2002$.

76 DOCTORS WITHOUT BORDERS (DWB), Untangling the Web, 2010. Available at www.utw.access.org. 
Graph 5 Competition as a price reduction catalyst: drop in the price of the first line combination of estavudine (d4T), lamivudine (3TC) and nevirapine (NVP) - 2000 to 2010

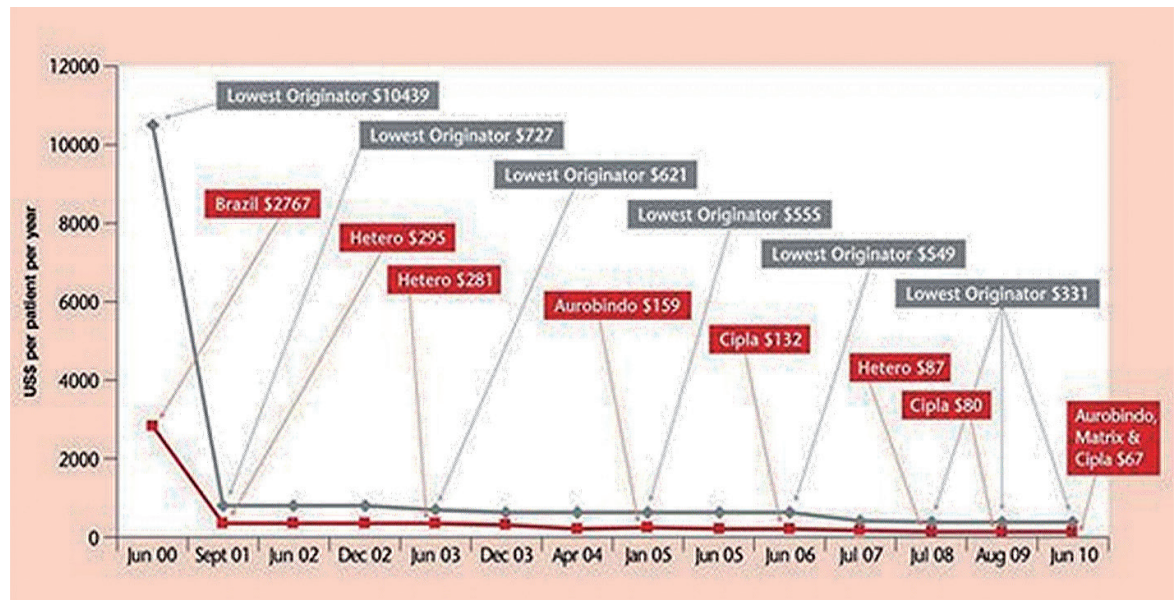

Source: Doctors Without Borders, 2010. www.utw.access.org.

With little to no competition, prices reach such a height that the population finds it difficult to gain access to proper treatment. A studied conducted by Harvard University suggests that access to medicines as a whole, in a no-patent scenario, would increase by $30 \%$ due to lower prices. ${ }^{77}$

\section{BRAZIL SAVED OVER US\$ 1 BILLION WITH GENERIC ANTIRETROVIRALS}

In Brazil, a study conducted in the end of 2007 suggested savings of public resources of over US\$ 1 billion from 2001 to 2005 regarding the purchase of six antiretroviral drugs alone, due to the negotiation of prices in an international competition scenario made possible by the existence of generic medicines. ${ }^{78}$

Medicines are necessary goods, that is, consumers cannot stop purchasing them and they cannot be replaced by other equivalent good. Data from the WHO estimates that $30 \%$ of the world population does not have access to the medical treatment they need. In Brazil, it is estimated that around 50 million people do not have access to medicines

77 BORREL, J-R and WATAL, J. Impact of patents on access to HIV/AIDS drugs in developing countries. Center for International Development at Harvard University Working Paper 92, Cambridge, 2002. Available at http://www.cid.harvard.edu/cidwp/pdf/092.pdf.

78 NUNN, Amy S. et al. Evolution of antiretroviral drugs costs in Brazil in the context of free and universal access to AIDS treatment, PLOS Medicine: November 2007, Volume 4, Issue 11, e305, p1804. Available at http://www.plosmedicine.org/article/info:doi/10.1371/journal.pmed.0040305. Access in 4 February 2009. 
and that $51.7 \%$ of Brazilians cease their medical treatment because they are unable to pay for the prescribed medicine. ${ }^{79}$

We have chosen the medicines selected below as examples of price differences in Brazil from when the patent was in force against generic versions available in the international market. Such comparison is possible because other developing countries such as India, for instance, have amended their national legislation to encompass pharmaceutical products' patents only in 2005, implementing a TRIPs safeguard - an option that Brazil did not make.

Table 4 Comparison of prices paid by Brazil and prices of generic versions for 4 medicines - price per unit in Brazilian Real R\$ - 2010

$\begin{array}{lrrr}\text { Medicine } & \begin{array}{r}\text { Price in Brazil - } \\ \text { average price per } \\ \text { unit (in R\$) }\end{array} & \begin{array}{r}\text { Generic price - } \\ \text { per unit } \\ \text { (in R\$) }\end{array} & \begin{array}{r}\text { Approximate } \\ \text { variation between } \\ \text { prices }\end{array} \\ \begin{array}{l}\text { Olanzapina } \\ 10 \mathrm{mg}\end{array} & 11,15(1) & 0,17(2)^{*} & 66 \text { times } \\ \begin{array}{l}\text { Atorvastatin calcium } \\ 20 \mathrm{mg}\end{array} & 3,10(1) & 0,61(2)^{*} & 5 \text { times } \\ \begin{array}{l}\text { Imatinib mesylate } \\ 400 \mathrm{mg}\end{array} & 120,70(1) & 6,71(3)^{*} & 18 \text { times }\end{array}$

Source: (1) Ministry of Health, Health Price Bank; (2) Monthly Index of Medical Specialties (MIMS); (3) Med Guide India. Available at: http://www.medguideindia.com/;

*Conversion rate: 0,03728 Real to Rupee (Central Bank of Brazil)

NB: A Olanzapina's patent came to term in 2010. Imatinib's main patent expired in 2012.

79 According to presentation by Dr. Mauro Sodré, the Brazilian Patent Office Attorney-General, during the VIII National Meeting of the 3rd Chamber of Coordination and Review of MPF, which took place in October 2007. Available (in Portuguese) at http://ccr3.pgr.mpf.gov.br/institucional/eventos/vii-encontro-docs/ VIII\%20Encontro\%20da\%203a\%20Camara\%20-\%20Relatorio.pdf. 
Graph 6 below illustrates the data:

Graph 6 Comparison of price paid by Brazil and prices of generic versions for 4 selected medicines - price per unit in $\mathrm{R} \$-2010$
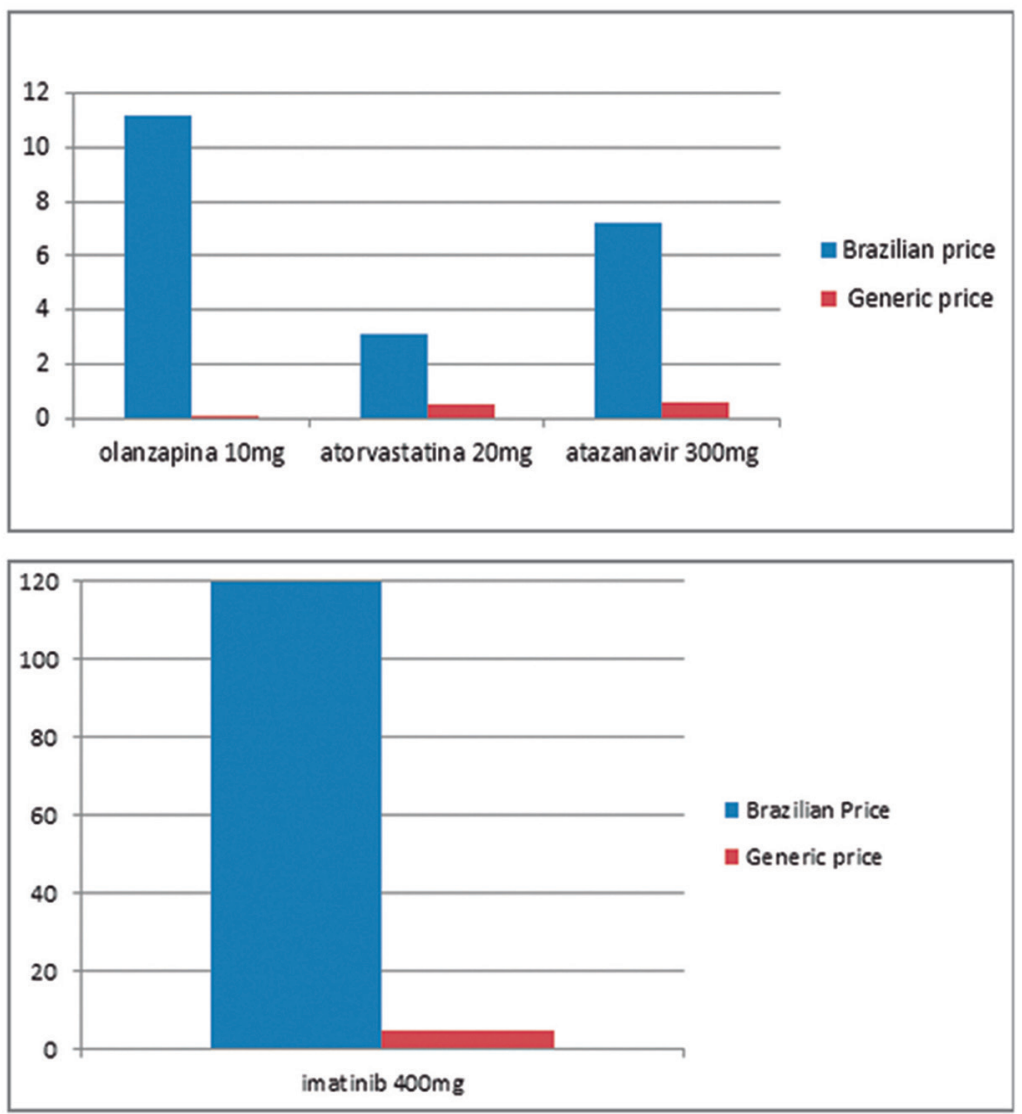

The graphs above present four medicines as examples of how the patent system impacts the public health budget. Olanzapine (Zypreza ${ }^{\circledR}$, Eli Lilly) is used in the treatment of schizophrenia; atorvastatin (Lipitor ${ }^{\circledR}$, Pzifer) is employed in the treatment of high cholesterol; atazanavir (Reyataz ${ }^{\circledR}$, BristolMyersSquibb) is employed in the treatment of HIV/AIDS; and imatinib (Glivec ${ }^{\circledR}$, Novartis) is used in the treatment of chronic myeloid leukemia.

When all the patents for the above medicines were still in force, they were distributed by the public health system, though the List of Exceptional Medicines of the National Health System - SUS or through the National Department of Sexually Transmitted Diseases (STD), AIDS and Viral Hepatitis. All were purchased by the Brazilian government or the population who bought them on their own from the patent holder companies, even when there existed commercial generic versions on the international 
market. During the patent term, the Brazilian government or population are not allowed to purchase the less expensive versions because patents in Brazil protect those medicines. ${ }^{80}$ Local production of those medicines is not allowed either.

Moreover, it is important to highlight another negative impact of the temporary legal monopoly bestowed by the patent system besides the effect on prices as previously evidenced: the lack of goods in the domestic market. Besides impacting the budget with elevated prices due to lack of competition, depending on a sole supplier can also compromise supplies, which ends up in patients not getting adequate treatment.

In February 2007, for instance, The National STD/AIDS Program published a technical note $^{81}$ advising the interruption of prescription and replacement of the antiretroviral medicine abacavir due to contract issues with the manufacturer that caused shipment delays. In the same year, the government halted the distribution of the drug nelfinavir and recommended its replacement after the medicine's recall by the company Roche. ${ }^{82}$

In both cases, the medicines were available in the international market, and there was even more than one option of generic medicine ${ }^{83}$. The country was, however, prevented from importing those versions due to patent protection. In 2010, there were shortages again, that time around of antiretrovirals abacavir, lamivudine, nevirapine and the association of lamivudine and zidovudine ${ }^{84}$. In 2011, another antiretroviral medicine was lacking in the domestic market, atazanavir ${ }^{85}$.

This is a fundamental issue, since a sudden medicine shortage can prove fatal to patients, or seriously compromise their health. Moreover, the substitution of a medicine may often mean reduced possibilities in terms of treatments due to risk of virus mutation, as well as the increased risk of the patient discontinuing their treatment.

These issues also call attention to the risk of being dependent of foreign products that are essential for the national population, as is the case with medicines. The domestic

80 The lapse of time needed by the Brazilian Patent Office nowadays to analyze a patent is of approximately 8 years, from the filing date to the final decision. During that period, the product is said to be subject to patent protection. Even though the applicant does not have patent holder rights during that time, the granting is retroactive to the filing date. Thus, if some other company explores the product that is subject to patent protection and the patent is issued afterwards, that company will have to compensate the patent holder for undue use of the product. In that context, we can say that during the period of analysis by the Brazilian Patent Office the product is subject to a de facto monopoly in spite of not being subject to it de jure.

81 MINISTRY OF HEALTH, Department of STDs, AIDS and Viral Hepatitis. Technical note no. 18/07 of 1 February 2007. Available (in Portuguese) at http://www.aids.gov.br/publicacao/nota-tecnican1807.

82 MINISTRY OF HEALTH, Department of STDs, AIDS and Viral Hepatitis. Explanatory note about the recall of antiretroviral drugs in Brazil. Available (in Portuguese) at http://www.aids.gov.br/noticia/nova-nota-deesclarecimento-sobre-o-recolhimentodo-antiretroviral-no-brasil.

83 O Instituto de patentes pipeline e o acesso a medicamentos: aspectos econômicos e jurídicos deletérios à economia da saúde, in Revista de direito sanitário, São Paulo v. 11, n 2 p. 164-188, jul/out.2010.

84 O ESTADO DE SÃO PAULO, Pacientes com HIV voltam a sofrer com desabastecimento de remédios. 17 de março de 2011. Available at http://www.estadao.com.br/estadaodehoje/20110317/not_imp693049,0.php

85 MINISTRY OF HEALTH, Department of STDs, AIDS and Viral Hepatitis. Technical note no. 066/2011. Available at http://www.aids.gov.br/publicacao/nota-tecnica-no-0662011dstaidshvsvsms. 
production of such remedies could minimize the risk of shortage, protecting the population's health.

Several mechanisms can be adopted by governments to minimize the impact of patents in the access to essential goods. Those measures are known as "safeguards" and are provided in the WTO TRIPs Agreement.

\section{TRIPs SAFEGUARDS}

The safeguards of chief interest concerning health provided on TRIPs are: exhaustion of rights (Article 6); interpretation of patentability requirements according to domestic criteria (Article 27); exceptions to patentability (Article 27); exception to rights conferred (Article 30); experimental use (Article 30); public non-commercial use (Article 31); compulsory license (Article 31); compulsory license in case of impossibility of local production (Article 31 bis); applications for revocation or cancellation (Article 62.4); transitional arrangements (Article 65); besides the possibility of adopting other "measures necessary" for the protection of specific sectors, which is the case of the Ministry of Health's role in the processes of filing for pharmaceutical patents (Article 8).

WHO, for instance, has already pleaded with its member countries to employ the TRIPs safeguards whenever it is made necessary for the protection of health ${ }^{86}$. And it urged its member countries to "to consider, whenever necessary, adapting national legislation in order to use to the full the flexibilities contained in the Agreement on Trade-Related Aspects of Intellectual Property Rights (TRIPS)" ${ }^{187}$

TRIPs, as mentioned before, is not automatically applicable in the domestic legal system, and, along with other provisions, safeguards also must be expressly implemented in the national legislation.

The CIPR Report from the United Kingdom, in that regard, recommends that developing countries provide "extensive safeguards to ensure that patent rights are not exploited inappropriately." 88

Ever since TRIPs came into force, several documents highlighting the importance of the implementation of safeguards by member countries to protect public health and

86 WORLD HEALTH ORGANIZATION. World Health Global Strategy and Plan of Action on Public Health, Innovation and Intellectual Property (WHA 61.21) (2008). Paragraph 5.2 (a) consider, whenever necessary, adapting national legislation in order to use to the full the flexibilities contained in the Agreement on Trade-Related Aspects of Intellectual Property Rights, including those recognized by the Doha Declaration on the TRIPS Agreement and Public Health and the WTO decision of 30 August 2003.

87 WORLD HEALTH ORGANIZATION. World Health Assembly. Intellectual property rights, innovation and public health. WHA56.27. 28 May 2003

88 See UNITED KINGDOM, Commission for Intellectual Property Rights (CIPR), Integrating Intellectual Property Rights and Development Policy, London, 2002. Available at <http://www.iprcommission.org/ papers/pdfs/final_report/ciprfullfinal.pdf>. 
to minimize the negative effects stemming from the patent system have been getting international approval under a strong leadership by the Brazilian government ${ }^{89}$.

The leading document adopted within the WTO's scope is the Doha Declaration on the TRIPs Agreement and Public Health, approved during the $4^{\text {th }}$ session of the Doha Ministerial Conference in Qatar ${ }^{90}$. With the signature of the Doha Declaration in 2001, WTO member countries have agreed that public health must take precedence over commercial interests, so that developing countries are able to secure its citizens the access to reasonably priced medicine.

\section{DOHA DECLARATION ON THE TRIPs AGREEMENT AND PUBLIC HEALTH}

The WTO Doha Declaration clarifies: "We recognize the gravity of the public health problems afflicting many developing and least-developed countries, especially those resulting from HIV/AIDS, tuberculosis, malaria and other epidemics. (...) 4. We agree that the TRIPs Agreement does not and should not prevent members from taking measures to protect public health. Accordingly, while reiterating our commitment to the TRIPs Agreement, we affirm that the Agreement can and should be interpreted and implemented in a manner supportive of WTO members' right to protect public health and, in particular, to promote access to medicines for all."

The negative impact of patents in the fulfillment of human rights has also been the object of analysis by other multilateral organizations besides the WTO. The UN Sub-commission on Human Rights states that "potential conflicts exist between the implementation of the TRIPS Agreement and the realization of economic, social and cultural rights" and singled out among such conflicts the "restrictions on access to patented pharmaceuticals and the implications for the enjoyment of the right to health".91

In the scope of the United Nations (UN), the countries took a step further and recognized not only the right to employ those protection measures ${ }^{92}$ but also and chiefly the duty of employing them towards the promotion of the human right to health.

89 WORLD HEALTH ORGANIZATION - resolutions approved in World Health Assemblies: 1999: Revised Strategy in Respect of Medicines (WHA 52.19); 2001: Strategy in Medicines by WHO (WHA 54.11); 2003: Intellectual Property, Innovation and Public Health Rights (WHA 56.27) and Health Sector World Strategy for HIV/AIDS (WHA 56.30); 2004: Expanding treatment and care within a coordinated and comprehensive response to HIV/AIDS (WHA 57.14); 2005: Strengthening preparedness and response to an influenza epidemic (WHA Resolution 58.5); 2006: Public health, innovation, essential health research and intellectual property rights: towards a global strategy and plan of action (WHA59.24); 2007: Public health, innovation and intellectual property (WHA60.30); 2008: Global strategy and plan of action on public health, innovation and intellectual property (WHA61.21).

90 WORLD TRADE ORGANIZATION. Declaration on the Trips Agreement and Public Health. WT/MIN(01)/ DEC/W/2. (2001).

91 UNITED NATIONS HIGH COMMISSIONER FOR HUMAN RIGHTS. Intellectual property rights and human rights. Sub-Commission on Human Rights Resolution 2000/7.

92 United Nations. A/HRC/RES/12/24, Paragraph 4 (2009). 


\section{PATENT RIGHTS SHOULD FULFILL THEIR SOCIAL ROLE (UN)}

The UN Committee On Economic, Social And Cultural Rights declared that "any intellectual property regime that makes it more difficult for a State party to comply with its core obligations in relation to health, food, education, especially, or any other right set out in the Covenant, is inconsistent with the legally binding obligations of the State party"93.

Moreover, the UN has adopted a resolution requiring that governments implement measures to protect the social role of the intellectual property on their national legislation and public policies, with the aim of clearly showing that patent rights are not an end in itself but a means to achieve economic, social and technological development. ${ }^{94}$

In 2009 the countries went even further and recognized no only the right to employ those safeguard measures but also, and chiefly, the duty of employing them toward the promotion of the human right to health. ${ }^{95}$

Still, the UN Committee On Economic, Social And Cultural Rights, in their General Comment no. 17 of 12 January 2006 explained that countries that signed the International Covenant on Economic, Social and Cultural Rights, such as Brazil, "[...] States parties thus have a duty to prevent unreasonably high costs for access to essential medicines, $[\ldots]$ from undermining the rights of large segments of the population to health, food and education."

\section{TRIPS AUTHORIZES EACH COUNTRY TO DETERMINE THE MOST APPROPRIATE IMPLEMENTATION OF THE AGREEMENT}

Article 1.1 of the TRIPs Agreement establishes that members of the WTO will freely determine the appropriate way to conduct the implementation of the Agreement within the scope of their respective systems and legal practices. Therefore, it behooves the signatory countries to decide their own way of implementing the TRIPs provisions.

93 UNITED NATIONS. SUBSTANTIVE ISSUES ARISING IN THE IMPLEMENTATION OF THE INTERNATIONAL COVENANT ON ECONOMIC, SOCIAL AND CULTURAL RIGHTS. Follow-up to the day of general discussion on article 15.1 (c), Monday, 26 November 2001. Human rights and intellectual property. Statement by the Committee on Economic Social and Cultural Rights. E/C.12/2001/15, par. 12.

94 UNITED NATIONS HIGH COMMISSIONER FOR HUMAN RIGHTS. Intellectual property rights and human rights. Sub-Commission on Human Rights Resolution 2000/7. Paragraph 5. (2000). applications Governments to integrate into their national and local legislations and policies, provisions, in accordance with international human rights obligations and principles, that protect the social function of intellectual property. 
In Brazil, Decree n. 1.355 of 30 December 1994 promulgated the final protocol that incorporated the results of the Uruguay Round of GATT multilateral trade negotiations, in force starting 1 January 2005. Since then, specific legislation would detail the Brazilian implementation, as the TRIPs Agreement creates obligations to member States but does not alter national law itself. TRIPs consists of a contract-treaty, which means that it is not self-applicable and, thus, the devices it provides have to be implemented by means of an act belonging to the national legal system.

The Brazilian industrial property act was modified in 1996 to fit the international rules. Brazil's legislation, however, did not adopt important measures to protect public interest policies allowed by the TRIPs Agreement and, instead, adopted stricter measures that what was established in this international agreement. ${ }^{96}$

The full adoption of health protection measures and the exclusion of detrimental measures besides the obligations already undertaken in a national scope could minimize the adverse effects of the industrial property system in the implementation of public policies that secure human rights in Brazil. Moreover, several studies and reports have been pointing out to the need to adjust national legislation cornerstones within this framework, especially concerning the right to health (UN, 2009a).

Thus, we present proposals for legislative amendments to the Brazilian Patent Act in order to, on the one hand, encourage innovation and, on the other hand, promote social interest and economic and technological development in the country, as determined by the Brazilian Constitution's Article 5, item XXIX: "the act will secure temporary privilege to authors of industrial inventions towards their use, as well as protection to industrial creations, $[\ldots]$ with a view to social interest and the country's technological and economic development".

96 See BENJAMIN, César. Lei de Patentes: Como o Brasil foi vencido, in Atenção, ano 2, n. 4, 1996. 


\section{THE PATENTABILITY REOUIREMENTS AND PATENT QUALITY}

The three patentability requirements present today in the Brazilian Patent Act - novelty, inventiveness and industrial application - must be rigorously observed both by the Brazilian Patent Office and the Judiciary, as void or frivolous patents could otherwise be granted. ${ }^{97}$ In addition to the traditional requirements, sufficiency of disclosure (enablement) and best mode, are the other two criteria present in the Brazilian Patent Act as well as in several foreign patent legislations, and these criteria must also be rigorously observed to prevent the grant of invalid patents that may eventually harm market competition.

The three requisites are: (a) novelty, that is, it is imperative that the invention is different from everything that has become accessible to the public before the filing date of the patent, by written or oral description, by use or any other means, in Brazil or abroad; (b) inventiveness or non-obviousness, by which it is understood that the invention cannot be considered evident or obvious by a person skilled in the art and (c) industrial application, which is the possibility that the invention may be used in any kind of industry. As already mentioned, in addition to the traditional requirements, there are other two criteria that are part of the social contract established by the patent system to create a balance between the personal interests of the patent holders and the public interest in access to patented technologies: (d) sufficiency of disclosure (or enablement), which demands that the product or process for which the patent is filed is clearly and sufficiently described so that a person skilled in the art can be fully capable of producing the patent and, lastly, (e) best mode, which demands that the best mode of execution of the invention is expressly detailed under risk of invalidation that the best mode of execution of the invention is expressly detailed under risk of invalidation. ${ }^{98}$

The CIPR Report commissioned by the government of the United Kingdom, while analyzing which are the best measures to be adopted by developing countries for their respective patent systems, recommended that the patentability requirements be applied according to "higher standards of patentability than those currently provided in many

97 In this regard, the recommendation contained in the Hargreaves Report, by the government of the United Kingdom, is that it must be ensured that only high quality patents are granted. See lan Hargreaves. Digital Opportunity. A Review of Intellectual Property and Growth. An Independent Report by Professor lan Hargreaves, 2011, p 58.

98 Novelty is provided in Articles 11 and 12; non-obviousness, in Art. 13, combined with Articles 11 and 12; industrial application is provided in Art. 15; sufficiency of disclosure, in Art. 24, and best mode of execution in Art. 24, all articles from Act 9.279/96. 
developed countries". 99 That is precisely what emerging States such as India and China did recently with the revisions of their Patent Acts in 2005 and 2008, respectively. ${ }^{100}$

With the employment of higher standards for patentability requirements, one is encouraging the capacity building and technological development in Brazil, keeping in mind that, for being less technologically advanced than, for instance the U.S., Europe, Japan and South Korea, we will have the legal possibility (that is, we will not violate foreign patents) and the time necessary to mature our technological development. ${ }^{101}$ That was, precisely, the public policy adopted both by South Korea and by Taiwan to support those countries in their technological development: first, imitation of technologies developed in other countries and only then development of their own technologies. ${ }^{102}$

We present some requirements and criteria for patentability in the following sub-chapters.

\subsection{Novelty}

Brazil adopts the absolute novelty regime, according to which the database used to assess the state of the art (all that was made accessible to the public prior to the filing date of the patent application, by oral or written description, by use or any other means, in Brazil or abroad) has to be collected from all over the world to enable the identification of what cannot be patented. ${ }^{103}$

Almost all countries adopt the absolute novelty regime. The U.S., as a protectionist measure, adopt the principle of relative novelty: that is, the information used to assess the state of the art are only gathered domestically, resulting, evidently, in a much larger number of granted patents.

We recommend that Brazil continue to adopt and apply the regime of absolute novelty, to prevent non-innovative patents from being unduly granted. In fact, in a truly globalized

99 See United Kingdom, Commission for Intellectual Property Rights (CIPR), Integrating Intellectual Property Rights and Development Policy, London, 2002. Available at <http://www.iprcommission.org/papers/pdfs/ final_report/ciprfullfinal.pdf>.

100 India reviewed its Patent Act in 2005 and implemented higher patentability requirements. See Feroz Ali Khader, The Law of Patents - With a Special Focus on Pharmaceuticals in India, LexisNexis Butterworths, 2007, and Srividhya Ragavan and Feroz Ali Khader, Proof of Progress: The Role of the Obviousness Standard in the Indian Patent Office, Global Perspectives on Patent Law, 2012. China reviewed its patent act in 2008 and implemented higher patentability requirements. See EU-China Project on the Protection of Intellectual Property Rights (IPR2), Third Revision of China's Patent Law: Legal texts and documents on the drafting process 2006-2008, 2010.

101 In addition, of course, there must be public policy of tax incentives, among other government incentives.

102 In order to accomplish this policy imitation, a few years ago these countries used a system of gradual increase in fees for the renewal of patents. See UNITED KINGDOM, Gowers Review of Intellectual Property, report by the government of the United Kingdom, 2006, p. 60.

103 Art. 11, § 1, of Act 9.279/96. 
world in which the WHO exists, it does not come off as sensible to adopt the principle of relative novelty.

\subsection{Inventiveness or Non-obviousness}

The requisite of non-obviousness is crucial for the employment of public policies consistent with the present stage of technological development in Brazil, and also so that patent system respects the patent Constitutional clause of promotion of technological, economic and social development (art. 5, XXIX, of the Brazilian Constitution).

Thus, the manner by which the non-obviousness requirement is employed by the Brazilian Patent Office as well as by ANVISA or the Judicial Branch can greatly influence the paths chosen by the country to advance in the innovation and technological qualification sector.

In that regard, the Gowers Report, by the government of the United Kingdom, recommends: "the removal of poor quality patents will improve the quality of the stock of patents. [...] This can be achieved by a stringent application of the novelty test and the inventive step test $[\ldots]$ "..104

The Brazilian Patent Act establishes that "the invention is endowed with nonobviousness whenever it is not derivative of the state of the art in any evident or obvious manner, in the judgment of a person skilled in the art" ${ }^{105}$

The Brazilian Act does not add any other ingredient to make the application of the nonobviousness requirement more rigorous.

\section{INDIA AND CHINA APPLY MORE RIGOROUS STANDARDS FOR THE NON-OBVIOUSNESS REQUIREMENT}

India reformed their Patent Act in 2005 so that, among other amendments, the requirement of non-obviousness could be more rigorously defined and applied, following a tendency not only of emerging countries but also more technologically advanced countries.

According to the new Indian Patent Act, non-obviousness means a characteristic of the invention that a) involves technical advancement in comparison with existing knowledge, or b) has economic relevance, or $\mathbf{c}$ ) both, besides not being obvious to a person skilled in the art. ${ }^{106}$

104 See UNITED KINGDOM, Gowers Review of Intellectual Property, report by the government of the United Kingdom, 2006, p. 82.

105 Art. 13 of Act $9.279 / 96$.

106 Art. 2(j a) - "'inventive step' means a feature of an invention that involves technical advance as compared to the existing knowledge or having economic significance or both and that makes the invention not obvious to a person skilled in the art", from the India Patent Act of 1970, reviewed in 2005. See Srividhya RAGAVAN and Feroz ALI KHADER. Proof of Progress: The Role of the Obviousness Standard in the Indian Patent Office, Global Perspectives on Patent Law, 2012., p. 6. 
Srividhya Ragavan and Feroz Ali Khader clarify that, moreover, the technical advancement requirement, although present in some inventions, may, however, be considered obvious in some circumstances. Thus, the mere presence of technical advancement does not render the patent application non-obvious. The holder of the patent application, therefore, must prove that there is a correlation between the technical advancement and a proof that this specific technical advancement show in the invention in fact renders the invention non-obvious and, thus, may possess non-obviousness. According to the authors, there must be, consequently, a proof of progress. If it is not proven that the championed invention in fact establishes some progress, it will not fulfill the non-obviousness requirement and, thus, will not be eligible for patenting. ${ }^{107}$

China has reformed its Patent Act in 2008 and much like India, implemented a more rigorous standard for the non-obviousness requirement.

According to the new Chinese Patent Act, in order for the non-obviousness requirement to be fulfilled, the invention must possess prominent and substantive differentiating features, as well as be representative of significant improvement in comparison with the state of the art. ${ }^{108}$

As clearly shown, emerging countries such as India and China have altered their Patent Acts to implement the requirement of non-obviousness more rigorously and thus, promote a truly innovative patent system and not just as a defensive of anticompetition strategy.

The non-obviousness requirement should be used towards encouraging sequential innovation, also known as follow-on innovation, or improvements over an initial innovation. The Federal Trade Commission of the U.S., commenting on the nonobviousness requirement, clarifies that "[f] or follow-on innovators, the size of the step required for patentability affects the choice between seeking ambitious or niche improvements." 109

In other words, if the standards for application of the non-obviousness requirement are low - as they are indeed nowadays in Brazil - any incremental or sequential innovator that promoted improvements, even if acting independently, must share his revenue or profits with the patent holder. The Federal Trade Commission of the U.S. suggests, for instance, that the non-obviousness requirement should be applied with a certain degree of rigor, even in their country, which boasts a high level of technological development;

107 See Srividhya RAGAVAN and Feroz ALI KHADER. Proof of Progress: The Role of the Obviousness Standard in the Indian Patent Office, Global Perspectives on Patent Law, 2012., pp. 7 e 35.

108 Art. 22(3) of the China Patent Act, reviewed in 2008. See EU-China Project on the Protection of Intellectual Property Rights (IPR2), Third Revision of China's Patent Law: Legal texts and documents on the drafting process 2006-2008, 2010, p. 15.

109 See FEDERAL TRADE COMMISSION, The Evolving IP Market Place - Aligning Patent Notice and Remedies with Competition, 2011, Chapter 4, pp. 4-6. 
and gives the following recommendation for the ideal application of the non-obviousness requirement: if the invention that is the object of analysis was already going to arise (and be commercially explored and publicized) very soon, then this invention does not deserve to be patented. ${ }^{110}$

Professor Jerome Reichman, from Duke University, alerts: “[...] low standards of non-obviousness would allow powerful foreign companies that accumulate patents on incremental innovations to block local improvers in developing countries and to maintain patent pools that could create formidable barriers to entry". ${ }^{111}$

In any case, in order for Brazil to advance and develop technologically, in addition to other government incentives in the area, it is advisable that, in the patent field, elevated standards for non-obviousness are implemented in our Act so that frivolous patents cannot be granted and sequential or incremental innovations are widely developed in the marked, which encourages technological qualification, in line with the Constitutional provisions.

\subsection{Sufficiency of disclosure - enablement}

In the chapter about the patent application, the Brazilian Patent Act makes itself clear in demanding that " $[\mathrm{t}]$ he report must describe the object clearly and sufficiently, enabling its production by a field expert, and also indicate, when applicable, the best mode of execution." (emphasis added - Art. 24). In addition to the sufficiency of disclosure in the report, claims must mandatorily be justified, with indication of the specificities of the application, defining clearly and precisely the object-matter of protection. (Art. 25) ${ }^{112}$ (translated from the original)

It is evident that sufficiency of disclosure is a sine qua non condition for granting a patent and, consequently, attesting to its validity. If the patent application does not feature a sufficient and clear description, enabling a field expert to produce the patent object, then the patent cannot be granted - if it is, it will be invalid or void. ${ }^{113}$

The insufficient disclosure of a patent object is contrary to the patent clause in the Brazilian Constitution (Art. 5, XXIX). If there is no sufficiency of disclosure, the competition will be harmed and, consequently, there will be damages to consumers and society. The patent system was designed with a careful balance in mind: on one

110 See FEDERAL TRADE COMMISSION, op. cit., Chapter 4, p. 6.

111 See REICHMAN, Intellectual Property in the Twenty-First Century: Will the Developing Countries Lead or Follow?, Houston Law Review, 2009, p. 1134.

112 Article 25 - "The claims must be based on the specification, characterising the particularities of the application and defining clearly and precisely the subject matter to be protected."

113 According to Articles 46 and 48 of the Patent Act, the patent granted in contradiction with the provisions of the Act will be invalid, and its invalidation will be effective from the application filing date. 
hand, the State grants temporary legal monopoly to the inventor and, on the other hand, the inventor must describe exactly and clearly their invention, enough to enable a field expert to execute or produce the invention that the patent object, in order to promote technological qualification. If there is insufficiency of disclosure, the patent is unconstitutional and invalid.

According to the U.S. Federal Trade Commission, patents must describe clearly that which they claim so that innovation can increase through encouraging collaboration, technology transfer and sequential and derivative innovation. ${ }^{114}$

China's Patent Act, for instance, in its Art. 26(3), rules that the patent application must describe the invention or utility model in a sufficiently clear and complete manner, so that a field expert can precisely replicate the invention. ${ }^{115}$

The matter of sufficiency of disclosure is of such importance that the U.S. Federal Trade Commission recommends the adoption, in that country, of a new legislation that redeems from infringement the person that makes use of a patent if this patent's claims have not been sufficiently described. ${ }^{116}$

As evident, sufficiency of disclosure is an essential criterion for the quality of a patent, and for the goals of the patent system to be duly respected. If there is no sufficiency of disclosure rendering the publicizing of the object and the patent claims to be sufficient, clear and complete, allowing all aspects of the invention to be precisely executed by a field expert, then the patent must not be granted and, if it is, it will be invalid ${ }^{117}$ and unconstitutional, seeing as the social contract and the balance established by the patent system would not have been observed.

\subsection{Best mode}

Another point to be observed that complements the integral description of the invention (sufficiency of disclosure) is the disclosure of the best mode of execution, in line with the U.S.' ruling. Along with the contents claimed in the patent application, the best mode of proceeding towards the production of the invention must be integrally described; otherwise, the patent can be deemed invalid or void.

114 See FEDERAL TRADE COMMISSION, The Evolving IP Market Place - Aligning Patent Notice and Remedies with Competition, 2011, pp. 3 e 9.

115 See EU-China Project on the Protection of Intellectual Property Rights (IPR2), Third Revision of China's Patent Law: Legal texts and documents on the drafting process 2006-2008, 2010, p. 16.

116 See FEDERAL TRADE COMMISSION, The Evolving IP Market Place - Aligning Patent Notice and Remedies with Competition, 2011, Chapter 4, p. 31.

117 According to articles 46 and 48 of the Brazilian Patent Act, a patent is invalid or void when granted contrary to the provisions of such act, and its invalidity will produce effects as from the filing date of the application. 
Art. 24 of the Brazilian Patent Act demands that "[t]he report must describe the object clearly and sufficiently, to enable its production by a field expert, as well as indicate, if applicable, the best mode of execution." (emphasis added; free translation)

The CIPR Report by the Government of the United Kingdom explains that "[ $\mathrm{t}$ ]he UK Courts have also recently stated that the disclosure must be sufficient to enable all aspects of the claimed invention to be performed, and the disclosure of a single manner of putting the invention into practice will not always be sufficient."118

Thus, in order that the Constitutional patent clause be respected, the criterion of best mode for an invention must necessarily be observed, or the patent will otherwise be deemed invalid or void - otherwise, the social contract established by the patent system would not be observed, disrupting the balance created between private and public interests.

\subsection{Legislative proposal}

Article 31-A shall be added to the Patent Act:

Art. 31-A. The Brazilian Patent Office shall offer an intuitive electronic channel, of easy access, connected to the Internet, for any person to present, free of charge, evidence or proof of previous existence, in Brazil or abroad, of the related invention or state of the art.

Sole paragraph. It shall be allowed the presentation of evidence or proof of prior existence, in Brazil or abroad, of the related invention or state of the art, even after a patent is granted, and especially during the opposition and the post-grant opposition procedures.

Articles 13 and 14 of the Patent Act is amended as follows:

Art. 13. The invention carries inventive activity when, for a person skilled in the art, it does not derive in an obvious or evident manner from the state of the art, and provided it represents a significant technical advance in regards to the state of the art.

Art. 14. The utility model carries inventive activity when, for a person skilled in the art, it does not derive in a common or vulgar fashion from the state of the art, and provided it represents a technical advance in regards to the state of the art.

118 See UNITED KINGDOM, Commission for Intellectual Property Rights (CIPR), Integrating Intellectual Property Rights and Development Policy, London, 2002. Available at <http://www.iprcommission.org/ papers/pdfs/final_report/ciprfullfinal.pdf $>$. 


\subsection{Recommendations}

\section{a) To Congress:}

a.1) approve Bill H.R. 5402/2013 to encourage sequential and incremental innovation through an increase in the quality of patents, and through the application of a high standard for the inventive step requirement (see Art. 3 of Bill 5402/2013, attached, that amends Articles 13 and 14 of the Patent Act).

\section{b) To the Executive Branch:}

b.1) to the Brazilian Patent Office (INPI):

b.1.1) apply the sufficiency of disclosure criterion so that the description of the object and the patent claims is, necessarily, sufficient, clear and complete to allow for all aspects of the invention to be executed, in a precise manner, by a person having ordinary skill in the art, at risk of the patent being invalid and unconstitutional otherwise;

b.1.2) apply with due rigor the best mode criterion to ensure that the patent applicant does not hold on to information that could be useful to third parties, at the risk of the patent being invalid and unconstitutional otherwise;

b.1.3) apply with due rigor the absolute novelty requirement, to prevent the grant of patents that are not truly innovative, at the risk of the patent being invalid and unconstitutional otherwise; and

b.1.4) apply with due rigor the non-obviousness requirement to prevent frivolous patents from being granted, aimed at stimulating sequential or incremental innovation.

\section{b.2) to the Sanitary Agency - ANVISA:}

b.2.1) apply the sufficiency of disclosure criterion so that the description of the object and the patent claim in the health field are, necessarily, sufficient, clear and complete to allow for all aspects of the invention to be executed, in a precise manner, by a person having ordinary skill in the art, at the risk of the patent being invalid and unconstitutional otherwise;

b.2.2) apply with due rigor the best mode criterion to ensure that the patent applicant in the health field does not hold on to information that would be useful to third parties, at the risk of the patent being invalid and unconstitutional otherwise;

b.2.3) apply with due rigor the absolute novelty requirement, to prevent patents in the health field from being granted when they are 
not truly innovative, at the risk of the patent being invalid and unconstitutional otherwise; and

b.2.4) apply with due rigor the non-obviousness requirement, so that frivolous patents in the health field are not granted, in order to encourage sequential or incremental innovation. 


\section{PRE-GRANT OPPOSITION}

The Brazilian Patent Act presently allows third parties to question a patent, either by judicial or administrative means, after it is granted. However, in regard to the participation of third parties before a patent is granted, the legislation only provides for the mechanism of presenting "input for examination", a feeble effort in comparison to other mechanisms such as, for instance, pre-grant opposition.

\section{RENOWNED STUDIES RECOMMEND PRE-GRANT OPPOSITION}

Professors from Harvard and Brandeis Universities Josh Lerner and Adam Jaffe recommend the creation of a pre-grant opposition system in their country. ${ }^{119}$ The CIPR Report from the Government of the United Kingdom makes the same suggestion. ${ }^{120}$

After being granted, patents can be rendered invalid or void before an invalidation action in court. The Brazilian Patent Act provides the chance for any person with legitimate interest to file for an ingringement action questioning the validity of a granted patent at any time during its term (Article 56 of the Patent Act). Legal suits are, however, usually costly and morose and, while there is no definitive decision, the patent holder still enjoys, in practice, the rights afforded by the patent.

Furthermore, well-trained and very expensive lawyers are certainly more accessible to multinational companies, while independent researchers, universities and smaller scale national companies do not enjoy that same privilege, consequently leaving the latter group in a disadvantageous position in comparison to the former.

\section{INDIA AND CHINA ADOPT PRE-GRANT OPPOSITION}

An option that countries can adopt to improve patent quality and decrease the financial and social costs of a long law suit of patent invalidation is to allow for patent opposition in the administrative scope, as in fact India and Chine opted for in 2005 and 2008, respectively. ${ }^{121}$ Note that, in India, opposition can happen at any time, even before the patent is granted.

119 See Adam B. JAFFE and Josh LERNER, Innovation and Its Discontents - How our Broken Patent System is Endangering Innovation and Progress, and What to Do About it, Princeton, 2004, pp. 180-183.

120 COMMISSION ON INTELLECTUAL PROPERTY RIGHTS. Integrating intellectual property rights and developing policy, Report of the Commission on intellectual property rights, London, UK 2002.

121 Art. 25(1) of the India Patent Act, of 1970, reviewed in 2005. 
Oppositions to patents can be presented beforehand, the so-called pre-grant oppositions, or after being granted by patent offices (post-grant oppositions) and can play an important role by putting forth elements that the examiner might eventually have overlooked, contributing to increase the quality of granted patents and to invalidate the granting of void patents that could negatively impact the access to the product that is the object of patent protection.

The Brazilian Patent Act presently provides the chance for any person with legitimate interest to file an administrative ingringement suit within six months from the patent grant (Article 51 of the Patent Act).

However, regarding the possibility of questioning a patent before its grant, the Brazilian Act has adopted the "input for examination" model (Article 31 of the Patent Act), by which interested parties can put forth documents and information to back the examiner's decision without any obligation by the examiner to take this information into account when taking his or her decision. ${ }^{122}$

In our understanding, the present legislative text renders that input very fragile, especially given the absence of any necessary manifestation from the examiner or patent applicant. Thus, we believe that the replacement of the input to examination institute for the pre-grant opposition institute provided by law in many countries such as India and China, for instance, can strengthen the participation of third parties in the process as well as, and most importantly, increase patent quality.

The Brazilian Patent Act has once adopted the pre-grant opposition mechanism:

\section{i) Law 16254, December 19, 1923}

Article 44. The order being regular, it will be published in the Official Gazette the characteristic points of the invention, of which the public may also have known in an appropriate place of the General Directorate of Industrial Property.

$\$ 2$. From the publication date referred to in this Article shall begin the 60-day period for acceptance. During this period, those who consider themselves harmed by the grant of the patent may submit their objections to the General Directorate of Industrial Property.

$\$ 3$. After the 60 days, there will be a competent examination, keeping in view not only the opposition parties, such as inventions already privileged, and any other elements that the Directorate General of Intellectual Property may deem useful.

122 Article 31, Brazilian Patent Act (9.279/96): "Documents and information for aiding examination may be filed by interested parties between the publication of the application and the termination of examination." 


\section{ii) Law 7903, August 27, 1945}

Article 26. The characteristic points of the invention will be published after the technical examination, for public and filing of oppositions, within thirty days from the publication date.

Article 27. Emerging third-party proceedings, the application shall be submitted to a new examination.

$\$ 1$. After this formality, or not having been presented challenges, the case shall be submitted for decision by the Director.

$\S 2$. A decision granting or denying a privilege or utility model may be appealed within sixty days.

\section{iii) Law 1005, October 21, 1969}

Article 20. Verified by preliminary technical examination that there is viability of privilege, it will be published at least one characteristic point of the invention, citing the total points, accompanied by a copy of at least one drawing, and statement of priority, if any, to submit any objections by interested parties within sixty days.

Sole paragraph. From the opposition notification date there will be sixty days to submit a reply.

$(\ldots)$

Article 22. Supplementary technical examination shall take place if opposition emerges, and it may be applicationed by the National Department of Industrial Property, as its substitute, the audience of other technical services, whether from the Public Administration, from organizations recognized by the Government as advisory bodies, from members of the teaching staff of higher learning universities, upon payment of "pro-labor" to the certified person skilled in the art.

Sole paragraph. The person in charge of the technical examination may application, stating the requirement, the information considered necessary, as well as new descriptive reports, feature points and designs, applying what is provided by Articlel8 and its paragraphs.

\section{iv) Industrial Property Code no. 5772/71}

Article 19. After the examination application is published, there will be a period of ninety days to submit any opposition, notifying the applicant.

$\$ 1$. The examination, which will not be subject to any initiatives on offered oppositions, will check if the claim of privilege is in accordance with legal requirements, if it is technically well defined, if there is no previous registration and if it is susceptible of industrial application.

(emphasis added) 
As evident, since the 1923 Act, the pre-grant opposition mechanism had been adopted by the Brazilian Patent Act. The 1969 and 1945 Acts mandated the need for a new technical examination or a complementary examination in case of third-party opposition to the analyzed patent application. The 1923 Act expressly determined that the examination had to consider the opposition of interested parties.

\section{SOCIETY PARTICIPATION IN THE PRE-GRANT OPPOSITION MECHANISM}

The 1969 Act went beyond and required, in case of opposition by third parties, an additional examination, letting the Brazilian Patent Office decide whether to consult with persons having skill in the art such as university professors. This is an exemplary procedure and runs side by side with the natural evolution of society, consisting of a collaborative and peer-reviewed work. This measure tends to increase the quality in patent examination and, consequently, the quality of granted patents - which would leave less room for invalid or void patents and legal uncertainty.

In the 1971 Code, the opposition mechanism was weakened by the provision according to which the examination was not to be conditioned to eventual manifestation about presented oppositions; however, there was the express provision that the applicant was to be notified about eventual oppositions. The present act does not even provide this mandatory condition, as there is no normative provision regarding what should be done in case an input to examination is put forth.

In reality, the pre-grant opposition mechanism was kept on the present Patent Act, but only for trademark applications, having been replaced by input to examination for patent applications. The article on trademark applications sets forth:

Article 158 - Once filed, the application will be published for the filing of oppositions within a period of 60 (sixty) days.

Paragraph 1 - The applicant will be notified of the opposition and may respond within a period of 60 (sixty) days.

Thus, for trademark applications, there is still the normative provision of the pre-grant opposition mechanism, including express provision of mandatory applicant subpoena.

As for the international scenario, Article 62.4 of the WTO TRIPs Agreement mentions that the legislation of a member country may include administrative measures of invalidation or pre-grant opposition to patents.

TRIPs Agreement, Article 62.4. Procedures concerning the acquisition or maintenance of intellectual property rights and, where a Member's law provides for such procedures, administrative revocation and inter partes procedures such as opposition, revocation and cancellation, shall be governed by the general principles set out in paragraphs 2 and 3 of Article 41. 
The TRIPs Agreement, then, leaves member countries the choice of which administrative mechanisms for third parties to challenge a patent to offer in their national legislations, indicating no mandatory device and no impediment in the adoption of whichever one.

\section{PRE-GRANT OPPOSITION: WORLDWIDE TENDENCY TO IMPROVE THE QUALITY OF PATENTS}

There is a worldwide movement for the adoption of pre-grant opposition to patents. As mentioned before, both India, in 2005, and China, in 2008, have altered their patent acts to implement the pre-grant opposition to patents. Despite the fact that the U.S., for instance, do not adopt a pre-grant opposition to patents process, they provide for a re-examination administrative procedure after granting. For some years now there has been an ongoing debate and tentative planning for a system of pre-grant opposition to patents in the U.S., precisely aimed at increasing the quality of patents and consequently avoiding long and costly litigation processes as well as great legal uncertainty prompted by the existence of too many invalid patents.

It is our understanding that pre-grant oppositions put forth by citizens, governmental bodies in the federal state or municipal level, universities or their research centers, non-profit research institutes, as well as non-profit non-governmental organizations must be free of charge, in order to achieve an adequate power balance. Oppositions put forth by other interested parties, however, should pay a fee determined by the public administration.

Thailand also allows for pre-grant opposition to patents put forth within 90 days after the patent application is published. In India, both procedures are allowed, pre and postgrant: opposition can be done at any time after the patent application is published, but before it is granted; and a post-grant opposition can be put forth within one year from the publishing of the patent grant. ${ }^{123}$ The table below summarizes the legislation in other countries. ${ }^{124}$

123 PARK, Chan. Challenging pharmaceutical patents: the case of India. p. 107. In WORLD HEALTH ORGANIZATION. Regional Office for South-East Asia. Intellectual property and access to medicines: papers and perspectives. India, 2010, pp. 108-109.

124 Based on PARK, Chan. op. cit. p. 108-109 and AMIN, Tahir. Challenging TRIPs: the role of patent oppositions. Presentation during TRIPs@10 at Columbia University. November, 2010. 


\begin{tabular}{|c|c|c|}
\hline $\begin{array}{l}\text { Pre-grant } \\
\text { opposition }\end{array}$ & $\begin{array}{l}\text { Pos-grant } \\
\text { opposition }\end{array}$ & $\begin{array}{l}\text { Submission of } \\
\text { comments or } \\
\text { observations }\end{array}$ \\
\hline Bangladesh & Brazil & Brazil \\
\hline Belize & Bhutan & Colombia \\
\hline Bolivia & South Korea & China \\
\hline Chile & China & El Salvador \\
\hline China & United States & Indonesia \\
\hline Egypt & India & \\
\hline Guatemala & Iran & \\
\hline India & Nepal & \\
\hline Israel & Pakistan & \\
\hline Jordan & Ukraine & \\
\hline \multicolumn{3}{|l|}{ Pakistan } \\
\hline Thailand & & \\
\hline Indonesia & & \\
\hline
\end{tabular}

Pre-grant opposition has been used by civil society groups and generic medicines manufacturers in many countries, preventing essential patented medicines from being granted or causing them to be considered invalid, making way for generic medicines competition and increasing access to treatment. To illustrate the matter, below are some examples of pre-grant opposition put forth by civil society in India ${ }^{125}$ and Thailand. ${ }^{126}$

\section{Oppositions to pharmaceutical patents put forth by civil society in India}

$\begin{array}{llll}\text { Medicine } & \text { Patent applicant } & \text { Opposition by } & \begin{array}{l}\text { Situation } \\ \text { of patent } \\ \text { application }\end{array} \\ \text { Zidovudine/lamivudine } & \text { GlaxoSmithKline } & \begin{array}{l}\text { Indian Network for People } \\ \text { Living with HIV/AIDS } \\ \text { and Manipur Network of } \\ \text { Positive People }\end{array} & \text { Withdrawn } \\ & & \end{array}$

125 GEORGE, Julie; SHESHADRI, Ramya; GROVER, Anand. Propriedade intelectual e acesso a medicamentos: evolução e iniciativas da sociedade civil na Índia. p. 148-149. In REIS, Renata; TERTO JR., Veriano; PIMENTA, Maria Cristina. (orgs.). Direitos de propriedade intelectual e acesso aos antirretrovirais: resistência da socie $\neg$ dade civil no sul global: Brasil, Colômbia, China, Índia, Tailândia. Rio de Janeiro: ABIA, 2011.

126 LIMPANANONT, Jiraporn; EKSAENGSRI, Achara; KIJTIWATCHAKUL, Kannikar; METHENY, Noah. Acesso ao tratamento da AIDS e proteção dos direitos de propriedade intelectual na Tailândia. In REIS, Renata; TERTO JR., Veriano; PIMENTA, Maria Cristina. (orgs.). Direitos de propriedade intelectual e acesso aos antirretrovirais: resistência da sociedade civil no sul global: Brasil, Colômbia, China, Índia, Tailândia. Rio de Janeiro: ABIA, 2011. 


\section{Oppositions to pharmaceutical patents put forth by civil society in India}

\begin{tabular}{|c|c|c|c|}
\hline Medicine & Patent applicant & Opposition by & $\begin{array}{l}\text { Situation } \\
\text { of patent } \\
\text { application }\end{array}$ \\
\hline $\begin{array}{l}\text { Nevirapine, } \\
\text { hemihydrate form } \\
\text { (syrup) }\end{array}$ & Boehringer Ingelheim & $\begin{array}{l}\text { Positive Women's Network } \\
\text { e Indian Network for } \\
\text { People Living with } \\
\text { HIV/AIDS }\end{array}$ & Denied \\
\hline $\begin{array}{l}\text { Tenofovir Disoproxil } \\
\text { Fumarate (TDF) }\end{array}$ & Gilead Sciences, Inc. & $\begin{array}{l}\text { Delhi Network of Positive } \\
\text { People e Indian Network } \\
\text { for People Living with } \\
\text { HIV/AIDS }\end{array}$ & Denied \\
\hline Tenofovir (Viread®) & Gilead Sciences, Inc. & $\begin{array}{l}\text { Delhi Network of Positive } \\
\text { People e Indian Network } \\
\text { for People Living with } \\
\text { HIV/AIDS }\end{array}$ & Denied \\
\hline Amprenavir & GlaxoSmithKline & $\begin{array}{l}\text { Uttar Pradesh Network of } \\
\text { Positive People and Indian } \\
\text { Network for People Living } \\
\text { with HIV/AIDS }\end{array}$ & Withdrawn \\
\hline Abacavir & GlaxoSmithKline & $\begin{array}{l}\text { Indian Network for People } \\
\text { Living with HIV/AIDS }\end{array}$ & Withdrawn \\
\hline Lopinavir & Abbott Laboratories & $\begin{array}{l}\text { Delhi Network of Positive } \\
\text { People, Network of Ma- } \\
\text { harashtra by People living } \\
\text { with HIV/AIDS and Indian } \\
\text { Network for People Living } \\
\text { with HIV/AIDS }\end{array}$ & Denied \\
\hline Ritonavir & Abbott Laboratories & $\begin{array}{l}\text { Delhi Network of Positive } \\
\text { People and Indian } \\
\text { Network for People Living } \\
\text { with HIV/AIDS }\end{array}$ & Abandoned \\
\hline $\begin{array}{l}\text { Efavirenz (pre-grant } \\
\text { opposition) }\end{array}$ & Bristol-Myers Squibb & $\begin{array}{l}\text { Delhi Network of } \\
\text { Positive People }\end{array}$ & Pending \\
\hline $\begin{array}{l}\text { Valganciclovir } \\
\text { (post-grant opposition) }\end{array}$ & $\begin{array}{l}\text { F. Hoffmann- } \\
\text { La Roche AG }\end{array}$ & $\begin{array}{l}\text { Delhi Network of } \\
\text { Positive People }\end{array}$ & Denied \\
\hline
\end{tabular}




\begin{tabular}{|lllll|}
\multicolumn{4}{|c|}{ Oppositions to pharmaceutical patents put forth by civil society in Thailand } \\
Medicine & Allegations & $\begin{array}{l}\text { Patent } \\
\text { application } \\
\text { date }\end{array}$ & $\begin{array}{l}\text { Opposition } \\
\text { date }\end{array}$ & Results \\
\hline ddl pills & $\begin{array}{l}\text { Processes and } \\
\text { products }\end{array}$ & 17 May 1999 & 14 Feb 2003 & Ongoing \\
\hline AZT + 3TC & $\begin{array}{l}\text { Formula AZT }+ \\
\text { 3TC + Glidants } \\
\text { (Combid) }\end{array}$ & 27 Oct 1997 & 11 May 2000 & Abandoned \\
\hline Nevirapine & $\begin{array}{l}\text { Use of } \\
\text { nemihydrate of } \\
\text { nevirapine in } \\
\text { liquid form }\end{array}$ & 18 Aug 1998 & 27 Feb 2001 & Ongoing \\
\hline
\end{tabular}

There is a lot to learn from India's experience. Significantly, the Indian legislation allows for patent opposition before and after the grant. Article 25(1) of the Indian Patent Act as amended in 2005 determines that the superintendent publishes the patent application and enables any entity or individual to challenge this patent even before its grant.

Article 25(2) of the Indian Patent Act, in its turn, allows any entity or individual to submit an opposition to a patent after its grant, but before the deadline of one year after the date of publication of the patent grant. One of the grounds for patent opposition is obviousness or lack of novelty - which consist of two of the patentability requirements (Society for Economic and Social Studies, 2007, at 40-47).

\subsection{Legislative proposal}

Article 31 of the Patent Act is amended as follows:

Art.31. From the publication of the patent application until the end of the exam, any interested party may file an opposition.

$\S 1$ The applicant shall be notified of the opposition through publication in the official gazette, and may respond within 60 days from the publication of the opposition.

$\$ 2$ In cases where an opposition to a patent application is filed, the Brazilian Patent Office may commission technical opinions from the Public Administration, from organizations recognized by the Government as consultancy bodies, and from university professors and students.

$\S 3$ After the opposition is filed, the examiner may, upon justified demand, application any additional clarification he/she deem necessary, as well as the presentation of supplementary documents.

$\$ 4$ The examiner shall mandatorily respond to each filed opposition, indicating the reason by which he/she accepts or rejects the arguments presented. 


\subsection{Recommendations}

a) To Congress:

a.1) approve Bill H.R. 5402/2013 to implement a pre-grant opposition mechanism - that will increase the quality of patents and substantially decrease legal uncertainty caused by frivolous or invalid patents (see Articles 3 and 4 of Bill 5402/2013, attached, that amends Art. 31 and creates Art. 31-A of the Patent Act).

b) To the Executive Branch:

b.1) to the Brazilian Patent Office (INPI):

b.1.1) invest in and improve the Brazilian patent database in order to offer, through open standards, open access to precise and detailed results on the evolution of all patent applications and the status of every granted patent to all;

b.1.2) implement, as soon as possible, search methods allowing for swift and easy access to all documents about chemical-pharmaceutical and biotechnological products and processes.

\section{b.2) to the Ministry of Science, Technology \& Innovation:}

Develop a program to enhance the participation of experts (professors, students, or any interest party), in the process of patent examination, in order to improve the patent quality, and to help the Brazilian Patent Office examiners in identifying the state of the art (non-obviousness requirement), as well as the novelty requirement, aimed at increasing the patent quality. 


\section{NON-EXTENSION OF THE PATENT TERM}

A patent term must, as high impact factor in the access to patented goods and so that the patent system remains duly balanced, consist of the time that is strictly necessary to allow for the financial recovery of the investment made by the patent holder - not a day less, nor a day more. Economist Edith Penrose, in a classic work, while approaching the patent term subject, has stated: "as no one has any idea what would be, on average, the number of years most economically advantageous for the duration of patents, the decision will remain a matter of political convenience". ${ }^{127}$

As the granting of a patent may have a negative impact in the access to the patented object because it can limit competition as well as buying options to a sole supplier, which leads to elevated prices due to the temporary legal monopoly, some checks and balances must be employed. In the case of pharmaceutical products, for instance, the patent grant gets in the way of health oriented public policies, besides limiting access to proper treatment by a large part of the population because of high prices stipulated by the patent holder. Thus, the patent term must be limited to what is established in international agreements between countries, without allowing for extensions.

The WTO TRIPs Agreement established a minimum patent term of 20 years. Any longer term would alter the exchange system between public and private interest established between society and the patent holder and goes beyond what was stipulated by international agreements signed by Brazil concerning patents.

\section{U.N. RECOMMENDS THAT DEVELOPING COUNTRIES DO NOT ADOPT TRIPS-PLUS MEASURES}

The UN Special Rapporteur for the human right to health approached the theme of implementation of the TRIPs Agreement and, after reaching the conclusion that the international system of patent and related rights was not achieving its goals and was limiting the access to medicines, recommended that developing and least developed countries reviewed their national legislations with the goal of working towards the full observation of the safeguards or flexibilities of the TRIPs Agreement as well as the exclusion of the TRIPs-plus measures, which are more restrictive than those imposed by the WTO and exacerbate the above mentioned problems. ${ }^{128}$

127 Apud GONTIJO, Cícero. Propriedade industrial no século XXI: direitos desiguais. Brasília: INESC, REBRIP, OXFAM, 2003. p. 22.

128 UNITED NATIONS. Promotion and protection of all human rights, civil, political, economic, social and cultural rights, including the right to development. Report of the Special Rapporteur on the right of everyone to the enjoyment of the highest attainable standard of physical and mental health, Anand Grover. Genebra: UN, 2009. A/HRC/11/12. 
Mr. Kenneth Nobrega, head of the Intellectual Property Division of the Brazilian Ministry of Foreign Affairs, who participated in the last round of debates held within the framework of this Report, regarding the implementation of the TRIPS Agreement pointed out that "Brazil went far beyond what it was bound to do." In other words, Brazil has adopted several TRIPs-plus measures in detriment to the national interest.

The extension of the patent term because of a delayed grant is a TRIPs-plus measure and, as such, must be excluded from the Brazilian Patent Act, with a view to the social interest in accessing patented technology as soon as the 20-year term expires, especially for technologies that make an impact on the actualization of human rights, as is the case of medicines.

The present Brazilian Patent Act fixes the term of a patent in 20 years from the filing date or 10 years from grant date, in case it is delayed:

Article 40, of the Patent Act - A Patent of invention will have a term of 20 (twenty) years and a utility model patent a term of 15 (fifteen) years, counted from the filing date.

Sole Paragraph - The term will not be less than 10 (ten) years for patents of invention and 7 (seven) years for utility model patents, counted from grant, except when the Brazilian Patent Office is prevented from proceeding with the examination as to the merit of the application, due to a proven pendency or for reasons of "force majeure".

In other words, if there is a difference of more than 10 years between the filing date and the grant date, the patent term will be of more than 20 years from the filing date. The sole paragraph of the Article 40 of the Patent Act, then, creates, based on the ineffectiveness of the Brazilian Patent Office, the possibility of an unreasonable extension in the protection term afforded by the patent, to the detriment of public interest.

Ever since the adoption of the TRIPs Agreement by the WTO the protection term of 20 years was extended to all members, thus homogenizing the legislations of all WTO member countries.

TRIPs Agreement, Article 33. Term of protection.

The term of protection available shall not end before the expiration of a period of twenty years counted from the filing date.

Thus, there is no obligation to extend the term of validity of a patent in case its grant is delayed. That is, therefore, a liberty taken by the Brazilian Act.

However, having in mind the great impact of patent protection on the access to patented goods, as highlighted above, it is our understanding that the 20 -year term counted from 
the filing that is already enough and any extension of this term is not reasonable and can be highly detrimental to society.

It is important to note also that the protection afforded by patents, for all practical purposes, becomes effective at the filing date and becomes known by the general public with all its details from the publication of the application, which happens within 18 months from the filing date.

That means there is no risk of an investor who knows about the existence of a patent application about a certain invention using it as, after the patent is granted, they could be prosecuted and forced to pay retroactive rights from the date they started using the invention. ${ }^{29}$ Thus, the inventor is protected for 20 years as provided by the Patent Act, based on the TRIPs Agreement, starting from the date of the filing of the patent, as the rights of the patent holder are retroactive to the filing date. It does not appear to us that the extension of the patent protection term is justified by Patent Offices's delay in granting the patent, since it does not meet the national interest provided for by the Constitution.

Moreover, it is not too much to remember that the exploration right provided by the Brazilian Constitution to authors of industrial inventions is a temporary right and that, in exchange for such right, the society can freely enjoy the invention after this period comes to term.

\section{Brazilian Constitution, Article 5, XXIX:}

The law shall ensure the authors of industrial inventions of a temporary privilege for their use, as well as protection of industrial creations, property of trademarks, names of companies and other distinctive signs, viewing the social interest and the technological and economic development of the country.

Thus, at the same time a patent is born, society's right is also born to use the patented object after a certain period of time, that should already be known at the time the application is filed.

In that regard, Pedro Barbosa ${ }^{130}$ states: "we still have the vested right of the society as a whole which was born along with the patent applications of - by the end of the privileges term - having access to public domain at a certain date".

That is, the access to a certain technology after the patent comes to term is a vested societal right and it is not reasonable to extend this term beyond what was agreed upon international patent protection rules, taking into account the great impact they make on access to patented technology.

129 Patent Act, Article 44 - "A patentee is guaranteed the right to obtain compensation for the unauthorized exploitation of the subject matter of the patent, including exploitation that occurred between the date of publication of the application and that of grant of the patent."

130 Barbosa, Pedro Marcos Nunes. O artigo 40 da LPI como propulsor de uma patente perene. 2007. 
The most important move is to equip the Brazilian Patent Office with the necessary conditions to fulfill their fundamental role within reasonable deadlines instead of creating conditions to increase protection term depending on the present ineffectiveness of the Brazilian Patent Office in examining all filed patent applications in a swift manner.

In practice, there are attempts to extend the patent terms for several years beyond the maximum protection term of 20 years. There was a plea for the extension of the term for the Bifentrina patent, which was filed in 1979, which means a 37-year term, which means 17 years beyond the usual term for a patent. ${ }^{131}$

\section{THE 'AVASTIN' DRUG CASE}

The cancer drug Avastin, whose patent would expire in 2018, will be in force at least until 2023, as its patent life spam will be 10 years from its grant.

Bevacizumab, marketed under trade name Avastin (Genentech / Roche) is a recombinant humanized monoclonal antibody approved in 2004 by the U.S. health agency (Food and Drug Administration - FDA) and used to treat various types of cancers such as colorectal cancer, lung cancer, breast cancer and renal cell cancer.

This product is claimed in four patent applications in Brazil, PI9809388, PI9809387 and its divisions PI9816306 and P19816350, all from Genentech (represented by Roche in Brazil) and filed on April 3, 1998. Correspondents of these applications have already been examined and granted in various countries such as Canada, USA, Japan and several European countries.

In Brazil, the first technical examination report for the application PI9809387 was issued on April 22, 2009, 11 years after the filing of the patent. This application has been granted by the Brazilian Patent Office and sent for approval to ANVISA, Brazil's sanitary agency, where it is pending, and the application was yet divided into PI9816306 and PI9816350, both still under examination by the Brazilian Patent Office.

Moreover, PI 9809388 has been granted by the Brazilian Patent Office and sent for ANVISA's approval, which approved it in June 2012. It will probably be granted by the Brazilian Patent Office.

These four applications filed in 1998 should be valid until 2018. However, 15 years after the filing of applications in Brazil, examination is still pending. Therefore, when the applications are granted, they will enjoy a validity period of 10 years from their grant date (as set forth by Brazilian Patent Act's Article 40, sole paragraph), resulting in a term of protection way beyond the regular 20 years term, i.e., the drug Avastin $\AA$ (bevacizumab) will have its patents in force until 2023, preventing the release of biosimilars, which therefore generates severe negative impacts to public health. 
In other countries, the patents for the same medicine will expire between 2018 and 2019.

It shall be recalled that this medicine had already had its patent granted in Brazil, i.e. the pipeline patent no. PP1101137, filed in 1992 and valid until 2011 in Brazil. This creates major distortions, for the extension of this patent will have a longer duration in Brazil than in other countries.

Having in mind that Genentech / Roche holds these patents and thus can prevent other competitors from producing bevacizumab, Roche is able to charge a price that best fits its taste without any competition. According to the K@iros database (brasil.kairosweb.com, accessed in October 2012) the price of an injectable Avastin pill (Roche) 400 mg costs R\$ 5,049.80.

The unreasonable extension of the protection period granted by the existence of the sole paragraph of Article 40 associated with the ineffectiveness of the Brazilian Patent Office works against society's interest, notably in essential sectors such as those concerning food safety and health. It is not reasonable to accept that significant fractions of the society be cut off from access to generic medicines for periods longer than 20 years, for instance, just because the Brazilian Patent Office was not given the necessary means and resources to examine patent applications filed in reasonable time. 
The following table brings 13 patents that have had their term extended due to the Patent Act's Article 40, sole paragraph:

Table 5 Medicines with extended patent term

\begin{tabular}{|c|c|c|c|c|c|c|c|c|c|c|c|c|c|}
\hline 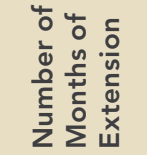 & 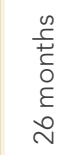 & 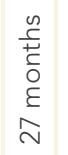 & 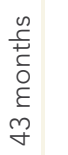 & 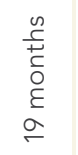 & 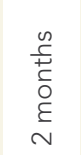 & 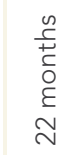 & 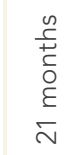 & $\begin{array}{l}\stackrel{n}{E} \\
\stackrel{+}{亡} \\
\stackrel{0}{0} \\
\text { E } \\
\varnothing\end{array}$ & 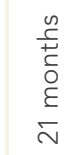 & 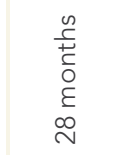 & 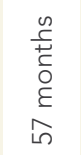 & 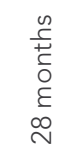 & 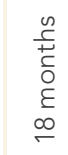 \\
\hline 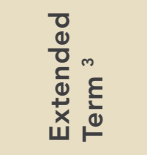 & $\begin{array}{l}\text { D } \\
\text { i } \\
\text { U } \\
0 \\
0\end{array}$ & 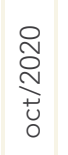 & 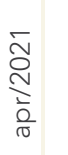 & 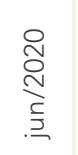 & 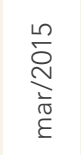 & $\begin{array}{l}\stackrel{2}{0} \\
\stackrel{N}{0} \\
\stackrel{0}{Q}\end{array}$ & 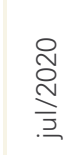 & 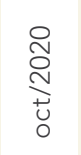 & 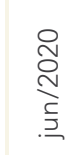 & 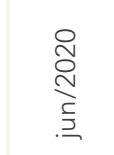 & 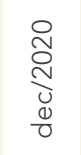 & 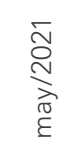 & 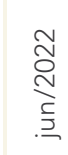 \\
\hline 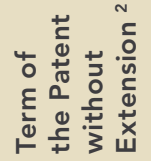 & $\underset{\substack{\stackrel{\infty}{\vec{U}} \\
0}}{\stackrel{\infty}{0}}$ & $\stackrel{\infty}{\stackrel{\infty}{\grave{D}}}$ & 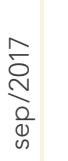 & 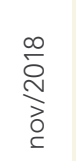 & 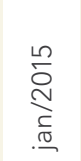 & $\frac{\infty}{\stackrel{\infty}{\frac{1}{2}}}$ & $\underset{\substack{\stackrel{\infty}{0} \\
0}}{\stackrel{\infty}{0}}$ & 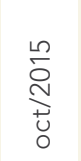 & $\underset{\substack{\stackrel{\infty}{0} \\
0}}{\stackrel{\infty}{0}}$ & $\begin{array}{l}\infty \\
\stackrel{\infty}{0} \\
\substack{0\\
}\end{array}$ & 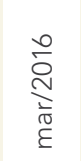 & 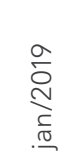 & $\begin{array}{l}\text { Ju } \\
\text { d }\end{array}$ \\
\hline 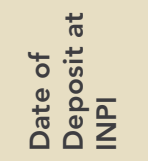 & 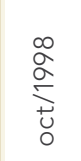 & $\begin{array}{l}\frac{\infty}{2} \\
\stackrel{2}{\rho} \\
\stackrel{.}{I}\end{array}$ & $\underset{\substack{\alpha \\
\alpha \\
\frac{\alpha}{\alpha} \\
\infty \\
\infty}}{ }$ & 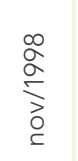 & 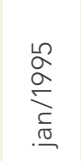 & $\frac{\infty}{2}$ & 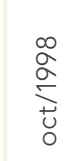 & 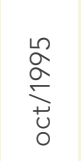 & 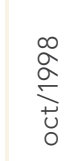 & $\begin{array}{l}\infty \\
2 \\
\alpha \\
\frac{\alpha}{0} \\
\frac{0}{0} \\
4\end{array}$ & 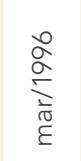 & 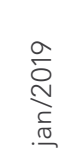 & 0 \\
\hline 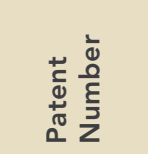 & $\begin{array}{l}\frac{f}{f} \\
\frac{f}{o} \\
\frac{o}{\alpha}\end{array}$ & $\begin{array}{l}\widetilde{O} \\
o \\
\circ \\
\infty \\
\frac{O}{\alpha} \\
\frac{o}{\alpha}\end{array}$ & 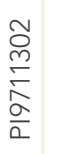 & 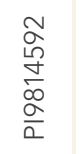 & 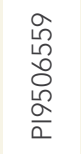 & $\begin{array}{l}\underset{N}{ } \\
\underset{N}{\infty} \\
\infty \\
\infty \\
\frac{O}{\alpha}\end{array}$ & 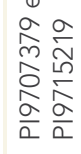 & 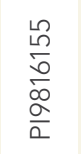 & $\begin{array}{l}\bar{a} \\
\stackrel{+}{o} \\
\stackrel{\leftrightarrow}{\alpha} \\
\frac{a}{\alpha}\end{array}$ & 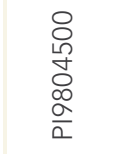 & 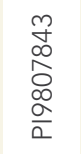 & 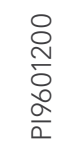 & $\alpha$ \\
\hline$\stackrel{\frac{u}{2}}{\underline{2}}$ & 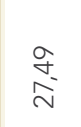 & $\begin{array}{l}\hat{N} \\
\tilde{0} \\
\text { مे }\end{array}$ & & $\begin{array}{l}\stackrel{+}{m} \\
\stackrel{\sim}{\sim} \\
\stackrel{+}{\leftarrow}\end{array}$ & $\begin{array}{l}\stackrel{ }{\circ} \\
\stackrel{\text { }}{n}\end{array}$ & 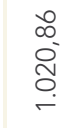 & 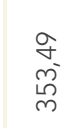 & 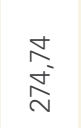 & & 总 & $\underset{\substack{\delta \\
\stackrel{\delta}{f}}}{\stackrel{N}{r}}$ & $\frac{\infty}{\stackrel{\infty}{\sigma}} \underset{\dot{\sigma}}{\sigma}$ & 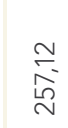 \\
\hline 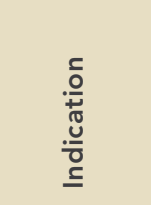 & 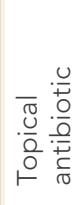 & 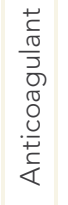 & 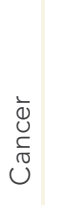 & 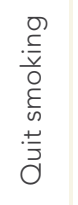 & 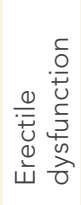 & 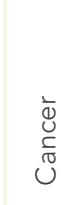 & 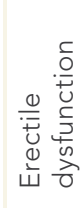 & 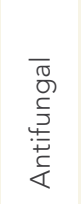 & 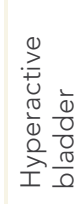 & 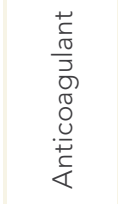 & 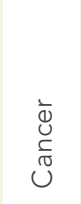 & 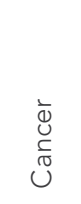 & 8 \\
\hline 妾 & 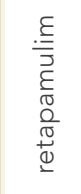 & $\begin{array}{l}\frac{1}{0} \\
\frac{0}{0} \\
\frac{0}{0} \\
\stackrel{+}{+}\end{array}$ & 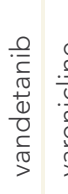 & 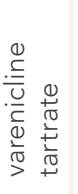 & $\begin{array}{l}\frac{\bar{F}}{\frac{\pi}{\pi}} \\
\frac{\pi}{0} \\
\frac{0}{0} \\
+\end{array}$ & 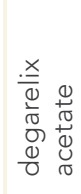 & 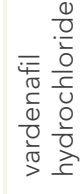 & 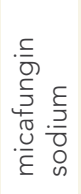 & 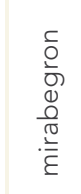 & 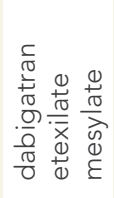 & 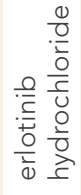 & 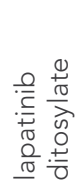 & \\
\hline 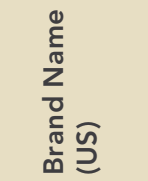 & 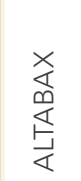 & $\frac{\mathbb{E}}{\stackrel{E}{z}}$ & 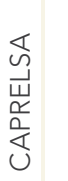 & 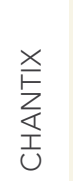 & $\frac{n}{\frac{\Delta}{U}}$ & 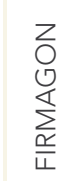 & 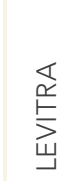 & 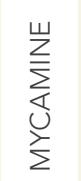 & $\begin{array}{l}\frac{o}{\underline{\underline{v}}} \\
\underline{w} \\
\underline{\underline{\alpha}} \\
\dot{\Sigma} \\
\Sigma\end{array}$ & $\begin{array}{l}\mathbb{x} \\
\stackrel{x}{\Delta} \\
\frac{\alpha}{\alpha} \\
\frac{1}{\alpha}\end{array}$ & 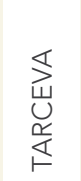 & $\begin{array}{l}\frac{\infty}{\widetilde{r}} \\
\stackrel{\vec{山}}{\Sigma} \\
\qquad\end{array}$ & \\
\hline
\end{tabular}

1 - Kairos - Feb. 2013. Amounts in Brazilian Real (R\$).

2 - Term that the patent should have if it were valid for 20 years from the filing date.

3 - Term of the granted patent in Brazil.

Updated: Feb. 2013 
Table 6 shows 52 patent applications pending examination which, if granted, will have their term extended due to the Patent Act's Article 40, sole paragraph:

Table 6 Drugs with patent applications already subject to extension (Art. 40, sole paragraph)

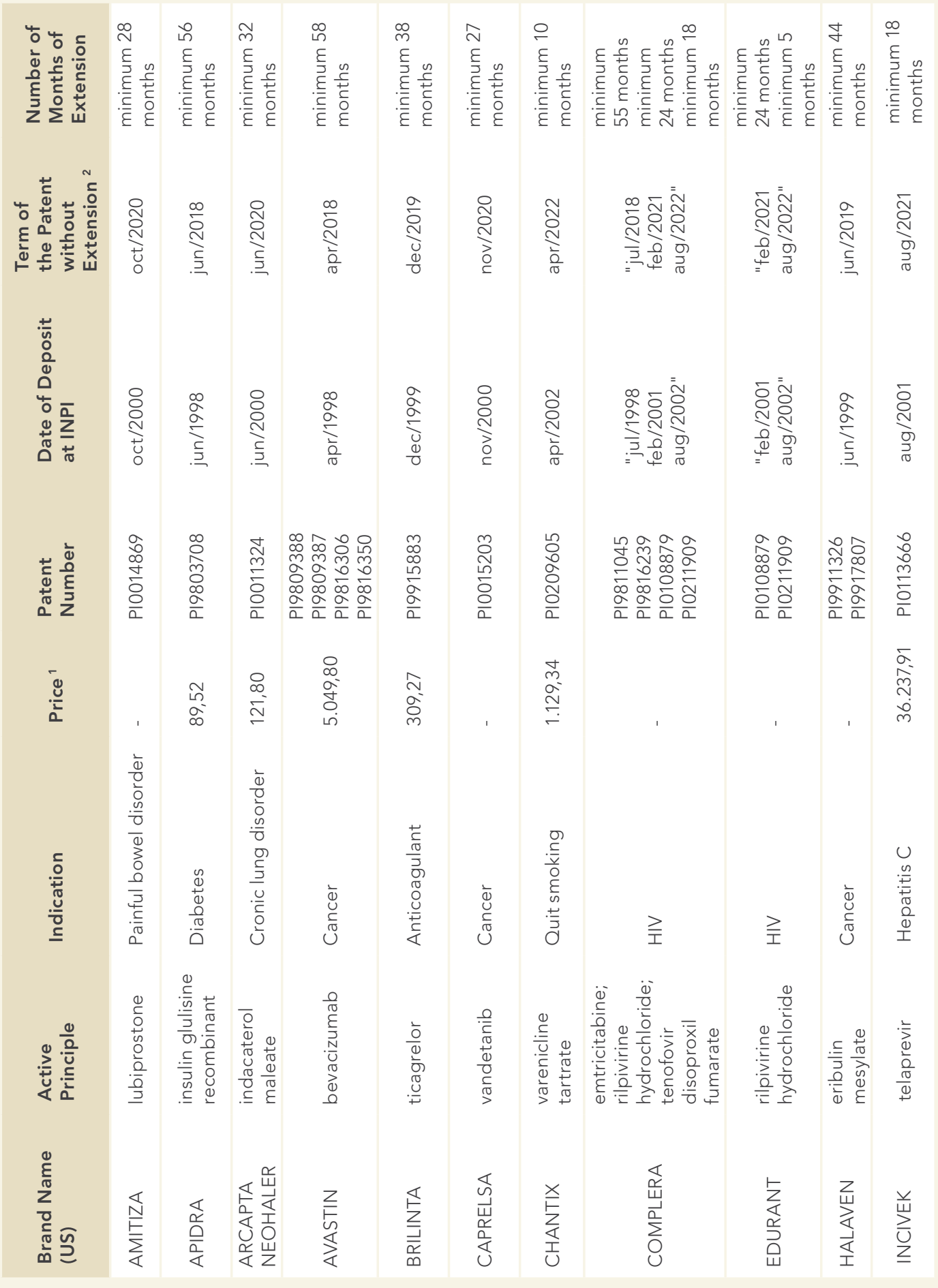




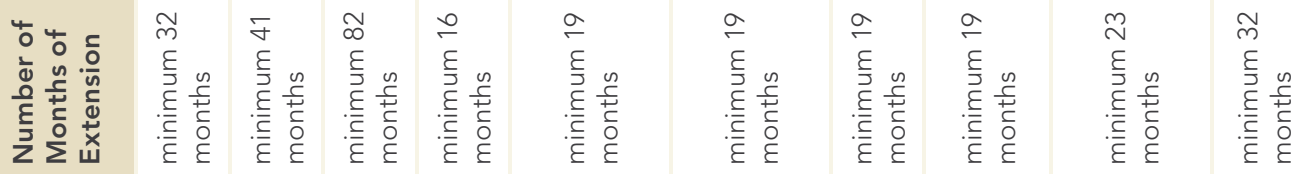

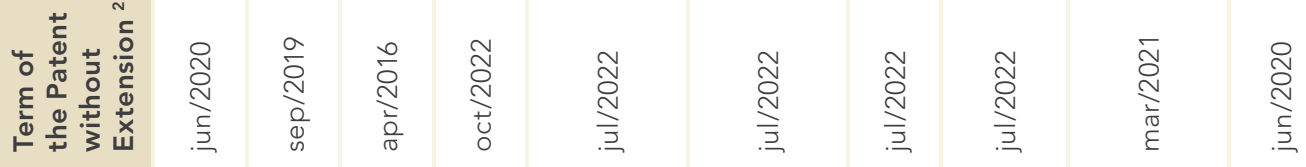

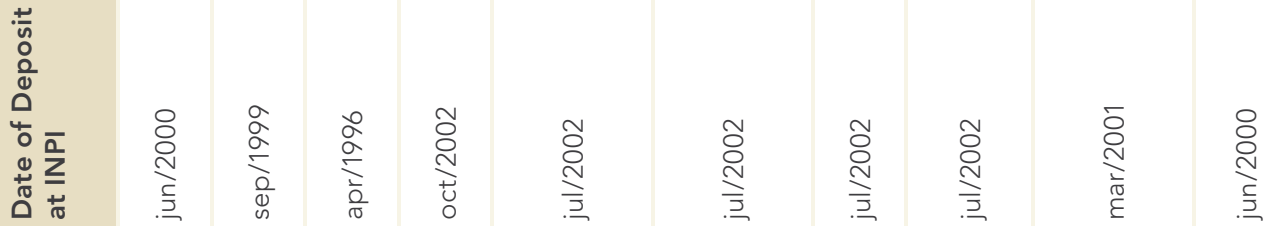

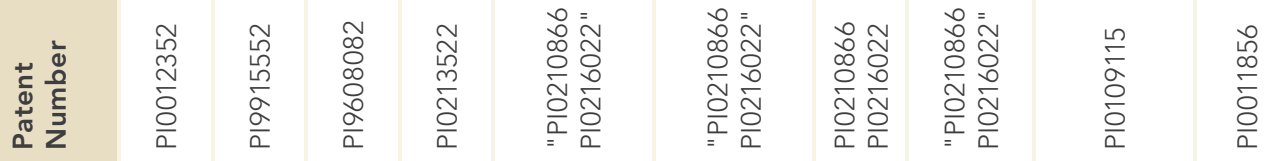

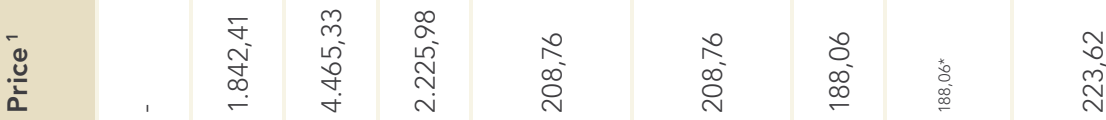

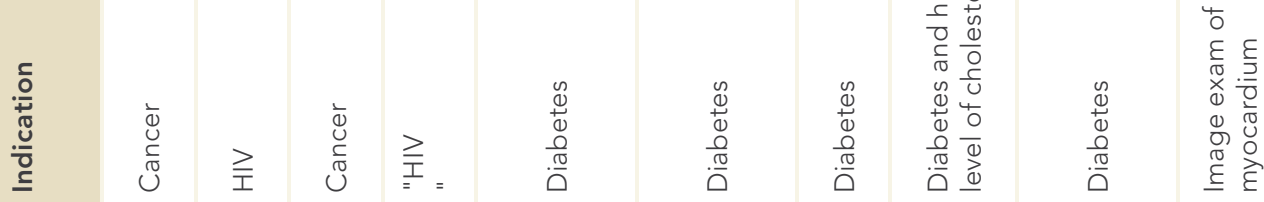

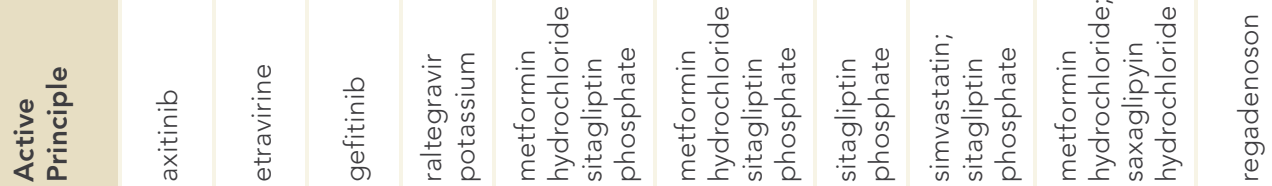

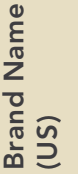

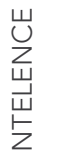

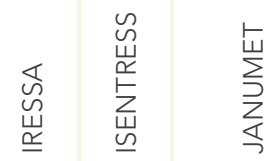

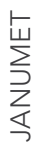

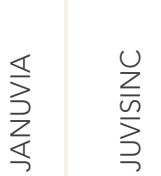

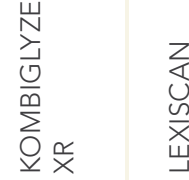




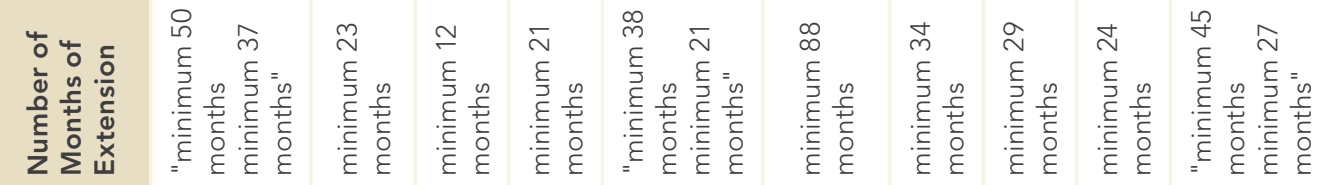

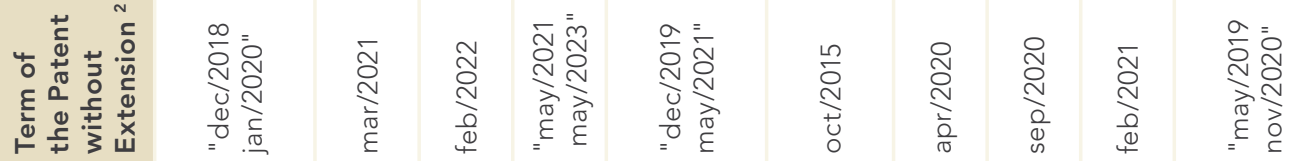

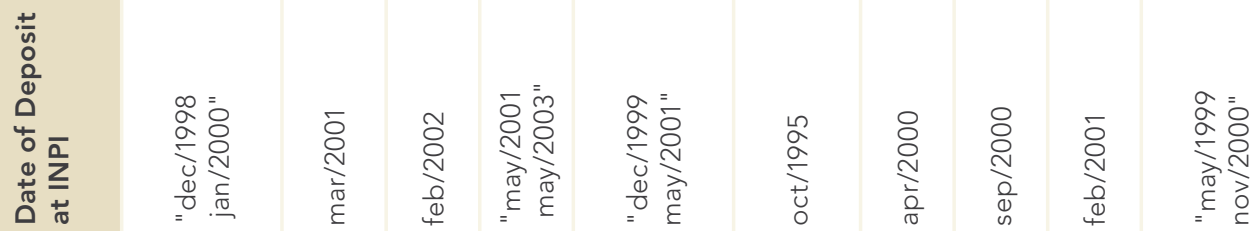

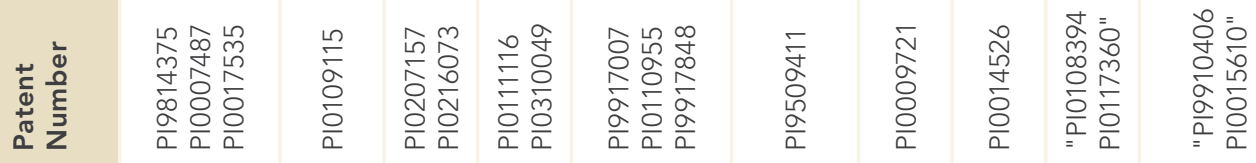

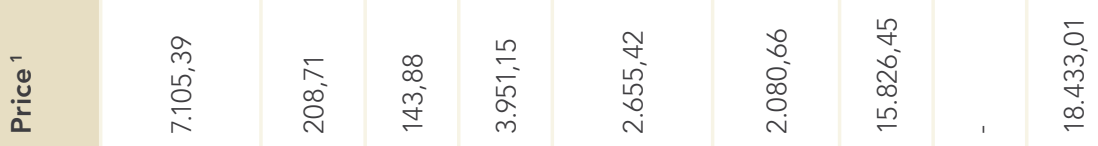

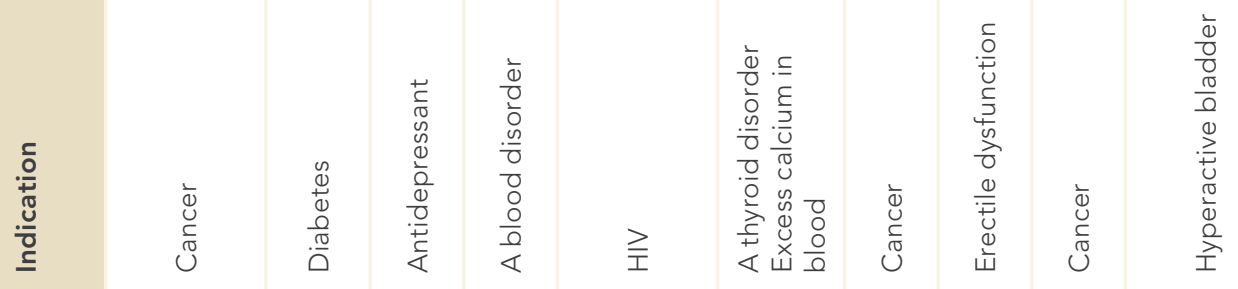

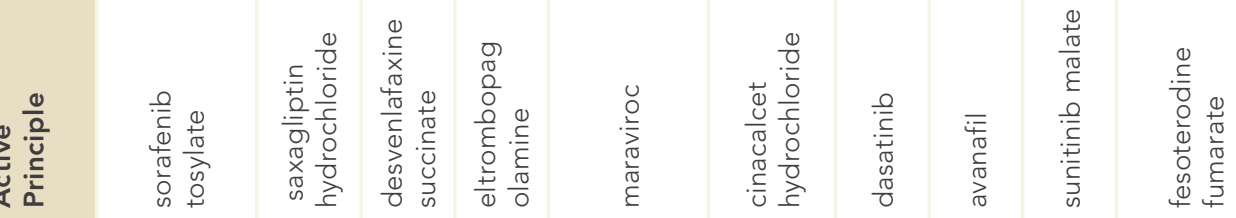

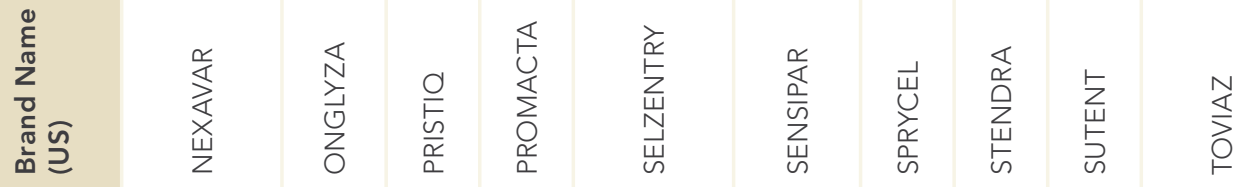




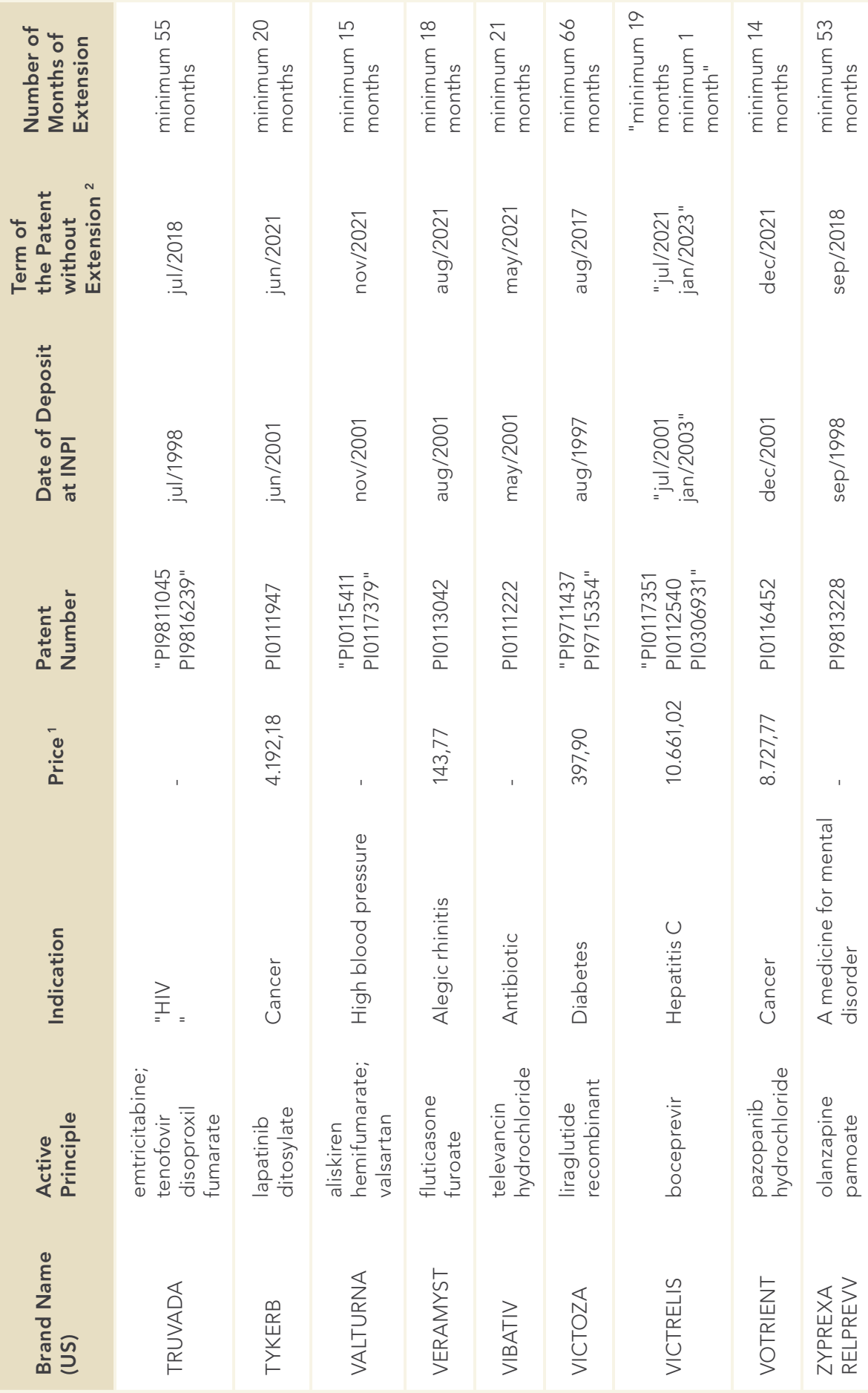

1 - Kairos - Feb. 2013. Amounts in Brazilian Real (R\$).

2 - Term that the patent should have if it were valid for 20 years from the filing date.

3 - Term of the granted patent in Brazil.

Updated: Feb. 2013

a) Not available in Brazil. Price for the drug JANUVIA (sitagliptina fosfato), from Merck

Sharp \& Dohme. - price of the medicine not available at Kairos. 


\subsection{Legislative proposal}

Taking everything into consideration, and so that Brazil does not extend patent terms beyond the baseline established by the WTO TRIPs Agreement, we recommend the exclusion of the sole paragraph of the Article 40 of the Patent Act (9.279/96), with the aim of making clear the impossibility of extending a patent term beyond 20 years due to delays in its granting.

It is befitting to note that the Bill (PL) 3.944/2012, authored by Congresswoman Jandira Feghali (PCdoB-RJ) and others, proposes exactly what we described. With that in mind, we recommend the approval of said bill.

\subsection{Recommendations}

a) To Congress:

Approve Bill H.R. 3.944/2012, sponsored by Congresswoman Jandira Feghali and others, proposing the revocation of the Patent Act Article 40's sole paragraph (see also Art. 2 of Bill H.R. 5402/2013, attached). 


\section{PUBLIC NON-COMMERCIAL USE}

By means of the government use mechanism, also known as public non-commercial use, the State has the right to use, or to authorize the use by third parties in their name and for specific non-commercial purposes, any patent granted, whether of a product or process, after communicating the patent holder and fixing proper remuneration, according to the provision of the TRIPs Agreement. It is important to stress that the government use also applies in case a private entity produces a good to be exclusively purchased by the State (CORREA, 2002).

This remuneration is not equivalent to the royalties usually fixed for a voluntary or compulsory license with commercial purposes. An equitable remuneration should be set to the patent holder having in mind that the public non-commercial use is not attached to a profit intent, as the technology that is subject to government use serves the public interest and is not employed for commercial purposes.

Government use is a safeguard to national interest and was first approached as a theme at the Lisbon Conference by the Paris Convention for the Protection of Industrial Property, in 1958. The debate was motivated by the unclear term for the use of the Compulsory License after the patent is granted as well as by the fact that some countries give different treatment to some kinds of patents such as food, medicines and those relevant to national security (PENROSE, 1974, apud CONSSENZA, 2010).

This institute gives the State the opportunity to correct certain situations in which patent and industrial creations rights hamper the access to essential technology.

In that context, patents have been instituted centuries ago, in several countries, as a mechanism towards technological development. Their stated goals were to stimulate and attract inventors to increase the offer of goods and services for society and expand the knowledge base available to that society by publicizing the invention.

In order to achieve those goals, the State began to grant the inventors a temporary market monopoly, a legal monopoly for a limited time over production and commercialization of the invention, whether it was a product or production process. Patents are, therefore, a legal creation instituted by governments in the name of the society they manage, with specific goals.

When granting monopoly, even for a certain term, the State gives an important message to society. Certain restrictions in the access to technological goods are allowed, while one hopes there would be promotion of technological development, by means of the patent, in the heart of the society. The society's interest is, therefore, critical in competitive arrangements and must be taken into consideration at any time. 


\section{THE CONSTITUTIONAL PATENT CLAUSE}

The Brazilian Constitution is clear and binds the grant of patent and related rights to the social interest and the economic and technological development of the country (Article 5, XXIX, CF/88).

The main advantage the patent holder has is actually a negative right, meaning that the patent gives the inventor the right to prevent third parties from "producing, using, offering, selling or importing" the object of invention without their authorization (Article 42 of the Patent Act).

The existence of a temporary legal monopoly instituted by the patent gives the patent holder the possibility of inserting his product in the market at higher prices (monopoly prices) than what would be possible in a free market regime. As mentioned, the negative right afforded by the patent gives the patent holder the opportunity to prevent the production and commercialization of the patent object in the country that granted the patent without their consent.

The market insertion of a product in monopoly conditions, at monopoly prices, creates what economists usually call a "market failure".

\section{MARKET RESERVE}

In some cases, the simple fact that the patent holder does not explore their invention, but only maintains their market reserve, which allows them to prevent third parties from exploring the patent, can be in itself advantageous to the patent holder. Hindering competition can already give them competitive advantages without the need for exploration.

If that behavior is proven anti-competition and/or is contrary to social interest and to the technological and economic development of the country, case-bycase, we are faced with an anti-competition practice or an abuse of patent rights liable for punishment in the competitive scope.

Given that, in a society, there is wide-ranging disparity of power of purchase, elevated prices cause a considerable part of society to be prevented from purchasing the product of invention, which would cause even larger divides in society, since the patent consists of a grant by society at large, while the benefit of the use of the product would be limited to a few. This fact is particularly important for inventions related to the fundamental needs of society such as those concerning the right to life, to education, to food security and to health. In those sectors, the competition issue must be at the front. 
Moreover, certain activities are exclusive to the State, such as those related to the monopoly of force, that is, activities concerning national defense and securing public order. The existence of patents of interest for the defense and maintenance of public order limits the action of the State and impose additional costs to the government's activities in those areas. Under those conditions, in order to play their essential role in matters of defense and public order, the State would be hostage to patent holders. ${ }^{132}$

\section{CHECKS AND BALANCES OF THE PATENT SYSTEM}

Economist Edith Penrose (1974) reminds us that, ever since the Paris Convention for the Protection of Industrial Property (CUP ${ }^{133}$ ), member countries already showed concern about unrestricted monopoly grant and their potential extreme costs for society. With that kind of support from the public interest, the State should see through measures to prevent the abuse of temporary legal monopoly given to a private organization.

That is why, historically, patent legislations have included some safeguards aimed at discouraging eventual abuse by patent holders and meeting the countries' public interests. Presently, the chief safeguards provided by the WTO TRIPs Agreement are: exhaustion of rights, also known as parallel import (Article 6); interpretation of patentability requirements according to domestic criteria (Article 27); exceptions to patentability (Article 27); exception to rights conferred (Article 30); experimental use (Article 30); public noncommercial use (Article 31); compulsory license (Article 31); transitional arrangements (Article 65); besides the possibility of adopting other "measures necessary to protect public health and nutrition, and to promote the public interest in sectors of vital importance to their socio-economic and technological development" (Article 8).

It is worth pointing out that not just the measures of promotion of public health should be safeguarded.

\section{THE TRIPS AGREEMENT \& PUBLIC INTEREST}

The TRIPs Agreement also provides that countries may adopt measures to promote public interest in vitally important sectors for their socio-economic and technological development (Article 8). 
In the case of Brazil, the Constitution also determines that the grant of patent and related rights must lead to the country's economic and technological development (Article 5, XXIX). Thus, the country can adopt measures aimed at the development of the national pharmaceutical sector, as well as the software sector, among others of clear relevance for its socio-economic and technological development and vital to the population's well-being, that are also legitimate and legally adopted within the national and international framework of patents rights.

We shall stress, moreover, that as Brazil's role has been, more often than ever, to absorb and legally imitate ${ }^{133}$ several technologies, with little innovation, it is important that the patent claim presents all necessary information towards the understanding of the way the processes and products patented work, including auxiliary procedures. In other words, it is essential that the patentability criterion (sufficiency of disclosure) be duly observed, at the risk of patent invalidation. The complete information about the patented technology is, in some cases, a very efficient mechanism to prevent the development of alternative technology, - and can be deemed, therefore, in a case-by-case basis, abuse of the patent right, also punishable in the anti-trust scope.

The Brazilian Patent Act contemplates the many safeguards while being remiss regarding the important safeguard that is government use. Despite being absent in the Patent Act, the institute of government use is not a stranger to the Brazilian legal framework as it is present on Act 11.484, from 31 May 2007, regarding the protection to integrated circuit topography, also known as chips. The Art. 47 of this Act says:

\section{Act 11.484}

Article 47 - The Public Authorities may make public, noncommercial use of protected topographies, directly or by contracting or authorizing third parties, observing the provisions of items III to VI of the main body of Article 49 and the provisions of Article 51 of this Law.

The inclusion of the public non-commercial uses safeguard in the Brazilian law regulation patent and related rights can offer society and the public interest an important tool for balance, as provided and authorized by the multilateral rules of the WTO, to propel public policies aimed at meeting important social demands regarding national defense, education, food security, technological development, as well as public health.

133 The public policy strategy adopted by both South Korea and Taiwan was the same (imitation of developed technologies first and then develop their own technologies). See UNITED KINGDOM, Gowers Review of Intellectual Property, report by the government of the United Kingdom, 2006, p. 60. 


\subsection{Public non-commercial use and the international legislation}

The WTO TRIPs Agreement authorizes public and governmental non-commercial uses of patents by means of its Article 31. In verbis:

Artigo 31. Outro Uso sem Autorização do Titular

Quando a legislação de um Membro permite outro uso (7) do objeto da patente sem autorização de seu titular, inclusive o uso pelo Governo ou por terceiros autorizados pelo Governo, as seguintes disposições serão respeitadas: (7) O termo "outro uso" refere-se ao uso diferente daquele permitido pelo art. 30.

a) authorization of such use shall be considered on its individual merits;

b) such use may only be permitted if, prior to such use, the proposed user has made efforts to obtain authorization from the right holder on reasonable commercial terms and conditions and that such efforts have not been successful within a reasonable period of time. This requirement may be waived by a Member in the case of a national emergency or other circumstances of extreme urgency or in cases of public non-commercial use. In situations of national emergency or other circumstances of extreme urgency, the right holder shall, nevertheless, be notified as soon as reasonably practicable. In the case of public non-commercial use, where the government or contractor, without making a patent search, knows or has demonstrable grounds to know that a valid patent is or will be used by or for the government, the right holder shall be informed promptly;

c) the scope and duration of such use shall be limited to the purpose for which it was authorized, and in the case of semi-conductor technology shall only be for public non-commercial use or to remedy a practice determined after judicial or administrative process to be anti-competitive;

d) such use shall be non-exclusive;

e) such use shall be non-assignable, except with that part of the enterprise or goodwill which enjoys such use;

f) any such use shall be authorized predominantly for the supply of the domestic market of the Member authorizing such use;

g) authorization for such use shall be liable, subject to adequate protection of the legitimate interests of the persons so authorized, to be terminated if and when the circumstances which led to it cease to exist and are unlikely to recur. The competent authority shall have the authority to review, upon motivated application, the continued existence of these circumstances;

h) the right holder shall be paid adequate remuneration in the circumstances of each case, taking into account the economic value of the authorization;

i) the legal validity of any decision relating to the authorization of such use shall be subject to judicial review or other independent review by a distinct higher authority in that Member;

j) any decision relating to the remuneration provided in respect of such use shall be subject to judicial review or other independent review by a distinct higher authority in that Member;

k) Members are not obliged to apply the conditions set forth in subparagraphs (b) 
and (f) where such use is permitted to remedy a practice determined after judicial or administrative process to be anti-competitive. The need to correct anticompetitive practices may be taken into account in determining the amount of remuneration in such cases. Competent authorities shall have the authority to refuse termination of authorization if and when the conditions which led to such authorization are likely to recur;

l) where such use is authorized to permit the exploitation of a patent ("the second patent") which cannot be exploited without infringing another patent ("the first patent"), the following additional conditions shall apply:

i) the invention claimed in the second patent shall involve an important technical advance of considerable economic significance in relation to the invention claimed in the first patent;

ii) the owner of the first patent shall be entitled to a cross-license on reasonable terms to use the invention claimed in the second patent; and

iii) the use authorized in respect of the first patent shall be non-assignable except with the assignment of the second patent.

(added emphasis)

Article 31 of the TRIPs Agreement establishes several hypothetic uses without the holder's authorization. They are more commonly known by the expression "compulsory license". Those licenses can be issued, for instance: i) to remedy anti-competitive or unfair practices (letter " $\mathrm{k}$ " in Art. 31); ii) in case of dependent patents (letter "l" in Art. 31); iii) in case of national emergency or other circumstances of extreme urgency (letter "b" in Art. 31); or iv) for public non-commercial uses (letter "b" in Art. 31).

Those hypotheses are merely for the sake of example and countries may establish any other motivations for compulsory license issuance, as expressly stated in the Doha Declaration, in verbis: Article 5 (b) - "Each member has the right to grant compulsory licenses and the freedom to determine the grounds upon which such licenses are granted."

\section{EXTENSIVE AUTONOMY FOR THE PUBLIC POWER}

As established by the TRIPs Agreement, in case of public non-commercial use, for instance, previous negotiation with the patent holder is not mandatory, while the other conditions remain valid, including a mandatory remuneration to the patent holder. In case of government use, the issuance of a license is not mandatory and remuneration of the patent holder is the sole obligation (LOVE, 2002, p. 74). 
In general terms, if compared to the grant of compulsory licenses, government use of patents is similar, but it is a much more direct and less restrictive sort of permission of use without previous authorization from the patent holder. This mechanism is perfectly adjusted to the interests of societies that may lack access to reasonably priced drugs according to local purchasing power (LOVE, 2002 , p.75). It befits to point out that not only can local production of goods be authorized by the government but importing the product for government use is also permitted (LOVE, 2002, p.75), as it is possible for a private organization to produce a good for the exclusive use by the State (CORREA, 2002).

The Brazilian legislation established several foundations for the emission of compulsory licenses; however, it has not established a simpler method for the government use of patents as many other countries' legislations have. In Brazil, the Patent Act, in its Article 68 , provides that the holder will be subject to have their patent compulsorily licensed if they enjoy their rights in an abusive manner or if the patent is used towards the abuse of economic power.

In regard to anti-competition aspects concerning technology and patents, Act 12.529/2011, establishing the Brazilian System of Competition Defense, lists several conducts that are characterized as infringements of the economic order (Art. 36 and items V, VIII, XI, XIV, XVIII, XIX). ${ }^{134}$

\section{TYPES OF COMPULSORY LICENSES AVAILABLE IN BRAZIL'135}

1. exercising patent rights in an abusive manner (Art. 68);

2. abusing of economic power by means of a patent (Art. 68);

3. failing to manufacture or insufficient manufacture of the patent object in Brazilian territory, or failing to use the entirety of the patented process except for cases of economic non-feasibility (Art. 68);

4. commercializing the patented product in such a way that it fails to meet market demand (Art. 68);

5. dependent patents (Art. 70);

134 See discussion on the subject in Chapter 10, covering compulsory licenses.

135 Compulsory license is the technical term as provided for in the Patent Act. The press in Brazil usually refers to compulsory licenses as "patent infringement" (quebra de patente), although it is not correct from a legal standpoint. Referring to compulsory licenses as "patent infringement" is not correct as the patent remains valid and held by its patent holder. Moreover, a mandatory payment of royalties for the use of the compulsorily licensed patent is due, as well as several legal requirements shall be observed. The difference regarding patents that were not compulsorily licensed is that their use can only occur after previous authorization by its holder. As for compulsorily licensed patents, there is no need for previous authorization, although royalties must be paid for its use, and the requirements established by the legislation must also be observed. 
6. national emergency declared by the Federal Executive Branch (Art. 71) ${ }^{136}$;

7. public interest declared by the Federal Executive Branch (Art. 71). ${ }^{137}$

Following the example of several technologically developed countries, a more simplified and less restrictive mechanism for the governmental or public non-commercial use of patents must be adopted by Brazil, as permitted by the WTO, independently of the compulsory license issuance hypotheses, which will remain ruled by existing legislation.

In countries with a Common Law legal heritage, government or crown use by commission or authorization of third parties is understood as essential and legitimate to the State that makes the rules and issues patent rights, and not as an infringement of patent rights.

\section{EXAMPLES OF COUNTRIES THAT AUTHORIZE GOVERNMENT USE OF PATENTS}

According to James Love (2002), several countries have solid laws for the public use of patents. In the United States (Section 28 of the United States Code, paragraph 1.498), for instance, the government can use a patent or authorize third-party use for practically any public use without previous negotiation. Patent holders do not have the right to question the validity of such use, and may only question the established remuneration. ${ }^{138}$ Similar mechanisms were adopted by the legislations of several countries such as Australia, Ireland, Italy, Germany, New Zealand, Philippines, Malaysia, Singapore, among many others (LOVE, 2002).

The United Kingdom has also adopted a similar mechanism to allow the use of a patented invention by the government or third parties authorized by the government (Article 55 concerning the use of patented inventions by the Crown). ${ }^{139}$ In India, the government or any authorized person may use a patented invention for government purposes, upon remuneration. (Article 100). ${ }^{140}$ Canada, Spain and China also integrate the extensive list of countries that provide for public non-commercial use of patents in their legislations. ${ }^{141}$

136 The hypotheses of compulsory license grant stipulated in the Article 71 of the Patent Act were regulated by Decree 3.201/99.

137 Idem.

138 Oliveira, Marcos. Medicamentos essenciais e licenças governamentais. Facto Abifina, 5th edition, Jan/Feb 2007.

139 Oliveira, Marcos. op. cit.

140 Idem.

141 Idem. 
According to Marcos Oliveira, "the [government use] mechanisms are not completely uniform, the remuneration method may differ, but the foundations are similar: the government may use any patent granted in its territory, as long as it is for government use and the inventor is remunerated." ${ }^{142}$ (translated from the original)

The U.S. are the country that most extensive and intensively employs the government use of patents, especially for government programs concerning defense and energy, but also in the health protection field, of which the cases of Meprobamate and Tamiflu. The American law institutes government use on Section 28, Paragraph 1.498 of the U.S. Code.

The dispositions listed on Article 31 of the TRIPs Agreement do not refer exclusively to the use of compulsory license, but also non-commercial public use. This differentiation is important from the legal framework standpoint, as there are substantive differences between compulsory licenses and governmental or non-commercial public uses We, therefore, propose the following improvement to the Patent Act:

\subsection{Legislative proposal}

Add Article 43-A to the Patent Act in order to introduce the public non-commercial use, also known as government use, as foreseen by the TRIPs Agreement. ${ }^{143}$

Art. 43-A. The Government, by Ordinance from the Minister of State concerned, may use the subject matter of a patent or of a patent application, for noncommercial purposes, without consent or authorization from the patent holder or patent applicant, directly or upon contract or authorization to third parties, for public interest purposes, including national defense and social interest.

$\$ 1$ Should the invention be a process, the public non-commercial use of the patent or patent application shall include the use in relation to any product that may be obtained by the process that is protected by the patent or the patent application;

$\S 2$ The Government shall notify the patent holder or patent applicant upon public non-commercial use;

$\$ 3$ Public non-commercial uses shall meet the following conditions:

I - not hinder the full exercise of the other rights of the patent holder or patent applicant;

II - be non-exclusive, and not admit sub-licensing;

III - be undertaken exclusively to serve the goals of the Ordinance that authorized it, resting assured that any other use that, without the character of public noncommercial use, would constitute an infringement of Art. 42 of this Act, is hereby prohibited;

$\S 4$ The remuneration for public non-commercial use shall be set by the Government, taking into account the circumstances of each use, shall take into account the percentage that would customarily incur upon a voluntary license

142 Oliveira, Marcos. op. cit.

143 Adaptation of proposal put forth by Denis Borges Barbosa in: BARBOSA, Denis Borges. Proposta para introduzir o uso público não comercial das patentes no direito brasileiro, 2010. 
between independent parties, applied over the cost for the Government resulting from the use of the subject matter of a patent or patent application, and weighed according to the collaboration supplied by the patent holder in the transfer of technology;

$\$ 5$ In the case of patent applications, the remuneration shall be legally deposited until the granting of the patent;

$\$ 6$ The Judiciary shall not, in regards of public non-commercial use, decide whether public interest purposes apply;

$\$ 7$ Public non-commercial uses shall not be lifted, limited or interrupted by legal appeal over the appointed remuneration.

\subsection{Recommendations}

\section{a) To Congress:}

Approve Bill H.R. 5402/2013 in order to implement in the Patent Act the noncommercial public use safeguard provided for by the WTO TRIPs Agreement (see Art. 4 of Bill 5402/2013, attached, that creates Art. 43-A of the Patent Act). 


\section{PIPELINE PATENTS - OR REVALIDATION PATENTS}

Brazil passed its Patent Act in 1996, with the objective of adjusting it to the internationally discussed parameters that were consolidated with the WTO TRIPs Agreement, signed in 1994. One of the chief alterations in the Brazilian law concerns the extension of patent rights to all fields of knowledge, including pharmaceuticals and foods, for which Brazil did not issue protection to products - only processes.

At the landmark of this legislative alteration, the question arose of what should be done regarding other products in those sectors that were patented in other countries and for which there was no patent application in Brazil due to the legal prohibition that was revoked with the new 1996 Patent Act. In this context, the mechanism of revalidation of foreign patents known as pipeline was adopted.

The pipeline mechanism is a transitional measure aimed at granting patent protection to products not otherwise patentable in countries undergoing alterations in their patent acts, by means of revalidation of a patent granted in a foreign country, without merit examination regarding patentability requirements in the country of revalidation, with total acceptance of the examination done in its original country ${ }^{144}$.

Thus, with the adoption of the Brazilian Patent Act in 1996, the pipeline mechanism was adopted, allowing for the protection of inventions of products in the pharmaceutical, chemical and food sectors that were not patentable before, for patent applications already filed abroad, but were not yet active in the market or commercialized. Those patents underwent a different processing mechanism from the other patents filed in Brazil.

By this mechanism, the pipeline patent application could be filed at the Brazilian Patent Office for a year after the Act came into force, in force for the remainder of the term of the patent granted upon its first application abroad or for the maximum limit allowed in Brazil (20 years), as provided in Articles 230 and 231 of the Patent Act. Among those applications, many were filed for the first time in one country and then, after some time, were abandoned, having been replaced by new ones. ${ }^{145}$

144 It is important to mention that, although frequently confused, the pipeline mechanism is not equal or equivalent to the mailbox mechanism provided in the TRIPs Agreement. Mailbox establishes that, while TRIPs is in force, national patent offices may receive patent applications in the fields for which there was no previous protection and keep them for later analysis when national patent law came into force, considering all requirements of patentability, including novelty. Mailbox was adoptd by the Patent Act, according to Article 229, sole paragraph. In the case of pipeline patents, retroactive protection came into force for applicationed or patented objects in other countries, within ot without the precedence term, situation in which there was no more novelty. Thus, the granting of patents for knowledge that already had known patents abroad even before TRIPs came into force was granted. Besides, pipeline patents do not undergo any analysis of merit in Brazil.

145 In some countries, there is possible extension of the patent term due to delays by the body in charge in authorizing commercialization of the medicine. Others, however, accept new dates for kickstarting the patent term when any novelty is introduced in the application. 
Those applications coming from abroad only went through a formal analysis and followed the conditions of the patent granted abroad, skipping a technical analysis of the patentability requirements of the Brazilian Patent Office. In that regard, Brazil forfeited the ability to interpret the patentability requirements (novelty, non-obviousness, industrial application and sufficiency of disclosure), according to its own criteria and interests, as authorized by the WTO TRIPs Agreement.

Pipeline patent applications as described had already been filed in other countries. Information disclosed by patents had already been published in industrial property magazines and other media.

\section{PIPELINE PATENTS ARE VOID AND UNCONSTITUTIONAL}

When those applications were filed in Brazil, they were already infringing the novelty requirement, since the information was already in public domain and, as such, were part of the state of the art. Those patents, then, could never have been granted, since they did not meet one of the patentability requirements. They are, therefore, invalid or void patents. ${ }^{146}$

Not only are they invalid and void, but pipeline patents are also unconstitutional, since they violate the patent clause ${ }^{147}$ determined by the Brazilian Constitution ensuring that the temporary privilege of exploration for industrial creations may only be granted with a view to social interest and the technological and economic development of the country (Article 5, XXIX). ${ }^{148}$

In that regard, according to Professor and jurist Denis Borges Barbosa, the grant of pipeline patents violates the principle of non-withdrawal of the public domain and affronts the vested rights of the society. ${ }^{149}$ Indeed, knowledge that enters the public domain can never be withdrawn from it. Its admission into public domain renders a certain asset a common good and the society is vested with the right of maintaining its availability, preventing its individual appropriation.

That is also the understanding of Nuno Pires de Carvalho, Board Director of the Economic Department of the World Intellectual Property Organization - WIPO ${ }^{150}$ :

146 According to Articles 46 and 48 of the Patent Act, the patent that opposes the provisions of the Act is invalid, and its invalidity shall be effective from the date of the patent filing.

147 Barbosa, Denis B. Inconstitucionalidade das patentes pipeline, 2006.

148 See António José Avelã Nunes et al. A inconstitucionalidade das patentes 'pipeline' brasileiras, in Revista Eletrônica do Instituto Brasileiro de Propriedade Intelectual (IBPI), Patentes Pipeline, special edition, November 2009.

149 Idem.

150 From presentation at the Legal Studies on Industrial Property Seminar, hosted by the Center for Legal Studies (Centro de Estudos Judiciários - CEJ) of the Federal Board of Justice (Conselho de Justiça Federal - CJF) in partnership with the the Brazilian Patent Office (INPI). Brasília, 2006. 
Up until May 1996, the Brazilian society had access to those inventions guaranteed by law. This access, moreover, did not depend on any conditions: it could be exercised at any given time.

Act 9.279/96 [Patent Act] has come to deny access to something to which society had, by virtue of the previous law, free access.

By acting retroactively and allowing for private appropriation, Act 9.279/96 violated the (diffuse) vested right of the Brazilian society of making free use of those inventions. (...) Law, effectively, and not just simple expectation, since the right to use an object of pipeline patent did not depend on any condition or future event. (...) Pipeline patents have harmed, then, the diffuse vested right of the Brazilian society to access cheaper medicines even if they are of foreign origin. (emphasis added)

The case of pipeline patents is emblematic in its disrespect to the principle of nonwithdrawal of public domain. Once knowledge is made available through publication of a patent application abroad, the Brazilian Legislative Branch cannot authorize the grant of a national patent which would withdraw knowledge from the Brazilian people stemming from the public domain, restricting free access to an already available asset, and, therefore, violating the constitutional precepts.

A historical decision by the Supreme Court of the United States is emblematic in that regard: "[the Congress] may not enlarge the patent monopoly without regard to the innovation, advancement or social benefit gained thereby, [nor] authorize the issuance of patents whose effects are to remove existent knowledge from the public domain, or to restrict free access to materials already available."151

The adoption of the pipeline mechanism happened by choice of the Brazilian Legislative Branch $^{152}$, and went beyond the obligations introduced in the international scope of the WTO, through the TRIPs Agreement. Brazil did not have the obligation to adopt this kind of patent, as it was not a TRIPs demand.

151 The U.S. Supreme Court, Graham v. John Deere Co. of Kansas City case, 383 U.S. 1,6 - 1966.

152 José Serra, Direitos privados versus interesses sociais. Available at: http://www.inpi.gov.br/noticias/ Panorama/setembro2001/mat_5.htm. Apud BARBOSA, Denis Borges. Inconstitucionalidade das patentes pipeline. Available at http://denisbarbosa.addr.com/pipeline.pdf>. 2006. p.53. Access: 22 November 2008. 


\section{FORMER MINISTER OF HEALTH JOSÉ SERRA ADMITS: PIPELINE PATENTS ARE UNNECESSARY AND HAVE NOT BEEN MANDATED BY THE WTO TRIPS AGREEMENT}

The then Ministry of Health, Mr. José Serra, at the time of the negotiations of the Patent Act, recognized that: "the introduction of the pipeline mechanism in the Patent Act was an unnecessary concession by Brazil, as it was not a TRIPs demand, and is still a target for criticism."

The adoption of a mechanism such as the pipeline was once proposed by the United States during the negotiation process of the TRIPs Agreement, and was rejected by the other countries for its incompatibility with the international system being created ${ }^{153}$. The WTO itself has spoken up regarding the absence in the TRIPs Agreement of protection to inventions with pipeline patents. ${ }^{154}$

According to data published by the Brazilian Patent Office, within one year from the publication of the Patent Act, 1,182 pipeline ${ }^{155}$ applications were filed, $63 \%$ of which concerning medicines ${ }^{156}$.

\section{EXAMPLES OF MEDICINES THAT HAVE BEEN PATENTED VIA PIPELINE AND THAT CAUSED SUBTANTIAL PREJUDICE TO BRAZIL}

Some medicines used in AIDS treatment such as Efavirenz, Abacavir, Amprenavir, Lopinavir, Lopinavir/Ritonavir and Nelfinavir were patented through the pipeline mechanism and, therefore, prevented the population and the government from having access to such medicines without having paid royalties to the (supposed) patent holders. medicines for the treatment of cancer, Alzheimer's, Parkinson's and schizophrenia have also been patented by means of the pipeline mechanism, and some of them are included in the Program for Exceptional medicines, subsidized by the Ministry of Health and managed by the State or Municipal Secretariats of Health Assistance.

153 See lectures by Nuno Pires de CARVALHO, Advisory Director at the Department of Economic Development of the World Intellectual Property Organisation (WIPO) and by Denis BARBOSA, professor at PUC/RJ, in Seminário de Estudos Jurídicos sobre a Propriedade Industrial, Brasília, Conselho da Justiça Federal, 2006.

154 WORLD TRADE ORGANIZATION - WTO. Available at http://www.wto.org/english/tratop_e/trips_e/ pharma_ato186_e.htm. Acesso em: 14 nov. 2007.

155 Data from the Patent Database of the the Brazilian Patent Office. Available at www.inpi.gov.br. Access: October 2008.

156 INSTITUTO NACIONAL DE PROPRIEDADE INDUSTRIAL - INPI. Nota sobre patentes e biotecnologia. Available at <http://www.inpi.gov.br/menu-esquerdo/informacao/pdf-dos-estudos/NOTA\%20SOBRE\%20 PATENTES\%20E\%20BIOTECNOLOGIA.pdf>. Access: 14 November 2008. 
Those medicines have taken their toll on the public health system in an absolutely excessive manner by rendering it impossible for the country to acquire cheaper generic versions available in the international market or producing them locally at more accessible prices.

In the case of the drug Imatinib Mesylate (Glivec $®$ ) by the company Novartis, used for the treatment of chronic myeloid leukemia, the Brazilian government cannot buy cheaper versions, although there are generic versions commercialized at substantially lower prices in the international market, as this medicine is protected in Brazil under a pipeline patent.

The cost per patient/year, of the drug Glivec, paid by the National Health System (SUS) of Brazil and offered in its generic version in India, in 2008, exemplifies the losses generated by pipeline patents for the Brazilian government: US\$29.612,00 (SUS costs) x US\$1.642,00 (cost of generics in India).

Pipeline patents have caused major negative effects in sensitive areas of social interest, especially concerning the access to medicines and the promotion to the right to health, and for the technological and economic development of the country - therefore going against the Constitutional rulings. ${ }^{157}$

\section{DAMAGES CAUSED BY PIPELINE PATENTS}

A technical opinion by the Institute of Economy of the Federal University of Rio de Janeiro (UFRJ) reckons that the losses caused by the adoption of the pipeline mechanism in Brazil for governmental purchases between 2001 and 2007 of five antiretroviral drugs used in the treatment of AIDS were of US $\$ 420$ or 519 million, compared to WHO or Doctors Without Borders (MSF) prices, respectively (Hasenclever et. al., 2010).

Considering that the sums presented in the following graph encompass only the total amount of the purchase of five antiretroviral drugs in the period between 2001 and 2007, and that the number of patents filed through the pipeline mechanism, mentioned before, goes up to 1,182, the same technical opinion by the Institute of Economy of UFRJ estimates that Brazil has had losses of the billion dollar with the granting of pipeline patents (Hasenclever et. al., 2010, p. 177). ${ }^{158}$

157 See Art. 5, XXIX of the Brazilian Constitution.

158 HASENCLEVER, Lia; LOPES, Rodrigo; CHAVES, Gabriela Costa; REIS, Renata; VIEIRA, Marcela Fogaça. O Instituto de patentes pipeline e o acesso a medicamentos: aspectos econômicos e jurídicos deletérios à economia da saúde. In Revista de Direito Sanitário, São Paulo v. 11, n. 2 p. 164-188, Jul/Oct. 2010. 
Graph 7 Difference paid for the pipeline patent by selected antiretroviral drugs based on the MSF price, 2001-2007 (\%)

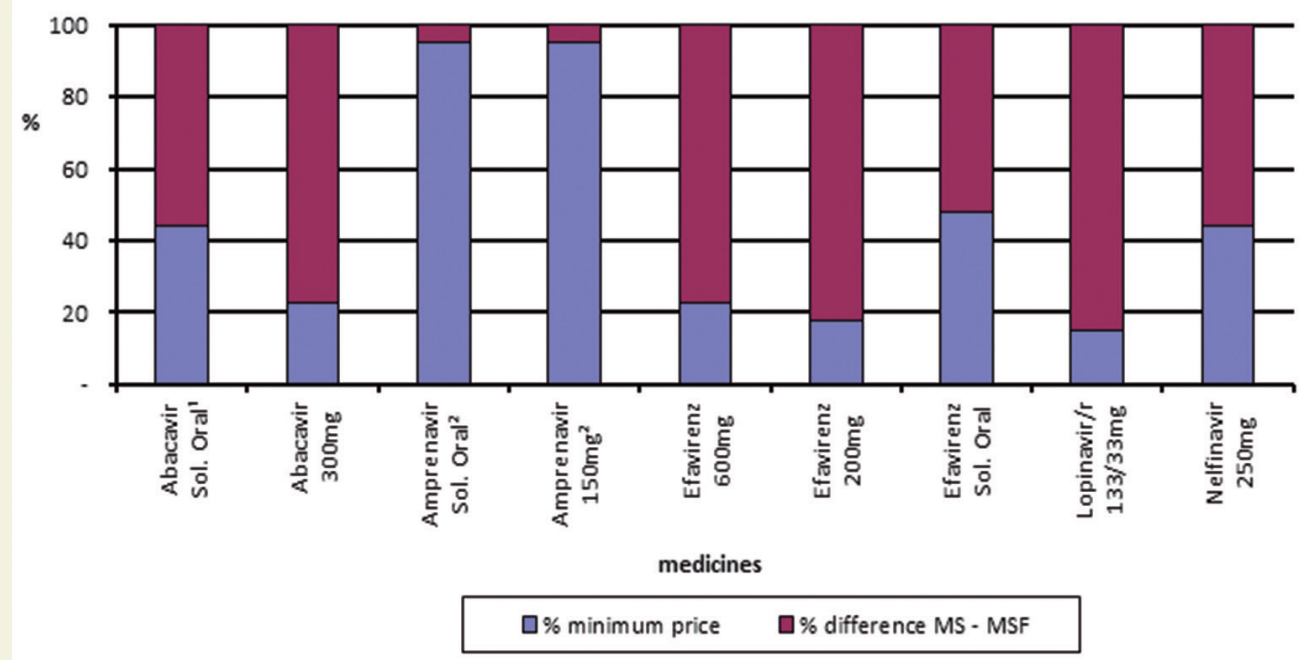

1 - Medicine with price quote for 2005 only;

2 - Medicines without price quotes for the WHO

Obs.: a) For the medicines without price quoted for the WHO or the DWB, they used royalties of $5 \%$ to calculate costs of the pipeline patent mechanism; b) Conversion based on the average dollar rate of 2006 (US\$1,00= $\mathrm{R} \$ 2,18)$; c) Calculation made base on the cheapest price found in June 2006 by the WHO.

Source: Hasenclever et. al., 2010

In addition to monetary losses, the pipeline mechanism also had negative consequences regarding the country's technological development.

\section{THE TRIPS-PLUS PIPELINE PATENTS MEASURE CAUSED STAGNATION AND UNEMPLOYMENT}

With the granting of pipeline patents, the local production policy for medicines has lost steam, as the government, the chief buyer in the Brazilian context, began importing them for the patent holder companies

Thus, there was an accelerated de-industrialization in the country in the chemical-pharmaceutical sector because the laboratories that produced generic medicines were no longer able to do so, a fact that also caused major unemployment in the sector.

Nelson Brasil ${ }^{159}$ reveals that the trade liberalization undertaken by the Federal Government throughout the 1990's, without establishing any adaptation period to the

159 Available in the document Cronologia do desenvolvimento científico, tecnológico e industrial brasileiro 1938-2003, Brasília, Ministério do Desenvolvimento, Indústria e Comércio Exterior, 2005. 
new market situation generated by the recognition of intellectual property rights has led to the closure of 1,906 productive units in the fine chemicals field, as well as the cancellation of 355 projects according to a survey conducted in the scope of the Ministry of Development, Industry and Foreign Trade.

\section{STUDY ESTIMATES THAT THE BRAZILIAN PHARMACEUTICAL INDUSTRY LOST NEARLY US\$ 1 BILLION IN EARNINGS}

In that same regard, a study by Abifina - the Brazilian Association of Chemical and Biotechnology Industries and its Specialties ${ }^{160}$ reveals that, in 2003, the chemical industry, with yearly imports of 7.5 billion dollars, was the chief trigger of the Brazilian commercial deficit, especially the fine chemicals sub-sector, with imports of around 3.5 billion dollars.

The study concludes that, as a consequence, the potential earnings of almost one billion dollars a year are forfeited by the national pharmaceutical-chemical park, a sum that expresses present imports and is five times the total exports, resulting in an elevated deficit in the segment's balance of trade, not to mention the major reduction in highly qualified jobs.

Another study by Abifina ${ }^{161}$ evidences that the amount lost by the local industry with the increase in imports in the chemical sector cannot be seen as trivial. If the ratio between imports of finished products and purchases in 1992 had remained constant throughout the decade of 1990, imports of around 4 billion dollars could have been avoided, resulting in a sum that could be aggregated to the local industrial production. It shall be noted that the imports of finished pharmaceutical products, ready for consumption, has a pernicious effect amplified in the local industry ensemble, affecting suppliers of raw materials, among others. On the other hand, the same study highlights that the economic effects of the loss of scale due to idleness of industrial installations and the loss of asset productivity cannot be overlooked.

The chemical sector (pharmaceutical and agricultural) is a segment with elevated strategic value for the country, as it concerns the food and health fields, while having major fragile aspects regarding the maintenance of services to the population.

160 ABIFINA. A indústria farmoquímica no Brasil. Apresentação à Subcomissão Especial de Assistência Farmacêutica e outros Insumos da Comissão de Seguridade Social e Família da Câmara dos Deputados. June 2003. Available at http://www.abifina.org.br/arquivos/abf_publicacoes/A_industria_farmo.pdf. Access: 14 November 2008.

161 ABIFINA. O impacto das importações no setor produtivo químico-farmacêutico do Brasil. 2005. Disponível em http://www.abifina.org.br/arquivos/abf_publicacoes/O_Impacto.pdf. Access: 14 November 2008. 
Pipeline patents were granted in the pharmaceutical and agrochemical industries against the technological, economic and social interests of the country, that is, in disagreement with the Brazilian Constitution. ${ }^{162}$

Thus, many experts understand that pipeline patents are unconstitutional, as they violate the goals of the patent system provided in the Article 5, item XXIX of the Brazilian Constitution by not promoting social interests or the technological and economic development of Brazil.

In 2007, a group of civil society organizations represented by the National Federation of Pharmaceutical Businesses (Federação Nacional dos Farmacêuticos - Fenavar) presented a complaint to the country's Attorney-General to file a suit before the Brazilian Supreme Court challanging the constitutionality of the pipeline mechanism.

In 2009, the then Attorney-General, Mr. Antônio Fernando Barros e Silva de Souza, file before the Brazilian Supreme Court a suit challanging Articles 230 and 231 of the Patent Act. ${ }^{163}$ The suit was filed under the number 4,234 and handed over to Justice Mrs. Cármen Lúcia Antunes Rocha. The rapporteur determined the application of information to the National Congress and to the President of the Republic and, soon after, a review to the Advocate-General and a pronouncement by the Attorney-General.

The respective information and pronouncement were duly served in the case, and reactions were put forth by several civil society, governmental and industry organization, in the quality of amicus curiae ${ }^{164}$. The suit is still awaiting trial by the Brazilian Supreme Court. If the pipeline mechanism is declared unconstitutional by the Brazilian Supreme Court, the technologies protected by pipeline patents will return to public domain in Brazil, since those patents would be considered invalid. Being invalid, technically and legally, their royalties should be returned, since they have been paid for a legally nonexistent object.

In addition to the suit at the Brazilian Supreme Court, there are still pending legal decisions concerning pipeline patents and there are still such patents in force in Brazil. That what makes it so relevant to approach the subject in this Report.

In Brazil, in case the unconstitutionality of the pipeline mechanism became evident, the pipeline protection term should be counted from its first filing abroad, according

162 See Art. 5, XXIX, da CF/88.

163 For a detailed analysis on the main arguments brought in ADI 4234 (Ação Direta de Inconstitucionalidade - Direct Action of Unconstitutionality), see Vieira, Marcela Cristina Fogaça. Proteção patentária para produtos e processos farmacêuticos: a questão da constitucionalidade das patentes pipeline. Monograph of completion of the lato sensu Post-Graduate Course in Intellectual Property Law and the New Information Technologies. Fundação Armando Álvares Penteado - FAAP. 2010.

164 All procedural documents are available for consultation at the Federal Supreme Court website (www.stf. jus.br), under the procedural ADI 4234. 
to the Patent Act. Extensions made abroad would not be accepted domestically. The multinational pharmaceutical industry, however, defends that the most recent date should be considered, while the Brazilian Patent Office defends the adoption of the least recent one.

The Judiciary's leaning, at first, was to favor the foreign companies. But that tendency gradually changed. Between 2000 and 2010, there were 67 decisions against the extension and 110 pro. That count includes all courts, which means that some may have been revoked in a superior instance, since the country's High Court of Justice (STJ) $)^{165}$ had decided, most of the times, in favor of not allowing the extension of patents -6 against the extention and 2 favorable to the extension.

\section{THE VIAGRA CASE}

The most publicized case in Brazil was the application for the extension of the Viagra patent. The Brazilian Patent Office managed to overturn the extension of the patent term of its active ingredient: the Second Chamber of the High Court of Justice understood that the patent should be in force until June 2010, and not June 2011, as Pfizer had managed to win in lower courts.

The rapporteur, Justice Mr. João Otávio de Noronha, voted in favor of the appeal filed by the Brazilian Patent Office jointly with the Federal Attorney-General Office, defending the end of the patent term in the original shorter period. Upon his vote, the rapporteur stated that the protection term for pipeline patents such as Viagra should be counted from the first filing abroad, even if it is abandoned, and mentioned the principle of independence of patents to show that the term is not always the same between countries. In the case of Viagra, its first filing was in 1990, in Great Britain, but it was abandoned in favor of a later application.

In March 2012, a legal decision invalidated the patent of lopinavir, one of the active ingredients of the drug Kaletra, owned by Abbott, which is part of the anti-AIDS cocktail offered by the Federal Government. Federal judge Daniela Madeira stated that the patent should not be valid due to lack of examination by ANVISA, the National Sanitary Agency, before its grant by the Patent Office and due to the unconstitutionality of the pipeline mechanism itself.

This patent was granted in 2000, therefore it should have undergone examination by ANVISA. The revalidation through pipeline should be considered unconstitutional for it granted a monopoly to a medicine that was already in the public domain, according to Cristália's attorney challenging the patent. 


\subsection{Pipeline patents in Comparative Law}

The mechanism of patent grant by means of revalidation, or pipeline mechanism, was also adopted by other countries, Argentina and Ecuador included. This type of patent, however, was deemed unacceptable by these countries' legal systems.

In 2000, the Argentinian Supreme Court of Justice, in a lawsuit over the invalidation of a revalidation patent by that country's patent office, decided that the concept of relative novelty present in the institute of revalidation patents is not compatible with the concept of novelty or with the reach of the priority princople, as resulting from the protection system instituted by the TRIPs Agreement. It is not compatible with the substantive norms of the Paris Convention either (Stockholm Revision of 1967), which must be followed by the TRIPs Agreement. ${ }^{166}$

Ecuador altered their patent legislation in 1994 to admit the possibility of granting patents to inventions already patented in other countries with the adoption of a relative - not absolute - novelty concept. Ecuador, however, is a signatory of the Cartagena Agreement, which adopts the concept of absolute novelty as a patentability criterion for an invention. By making patents for inventions that have already been patented abroad (pipeline) possible, Ecuador would be forfeiting the principle of absolute novelty, adopting a concept of relative novelty and thus violating the Cartagena Agreement. The Committee of the Cartagena Agreement, filing Lawsuit No. 1-AI-96 at the Andean Community Court of Justice, thus questioned the alteration of the Ecuadorian legislation.

Throughout the lawsuit process, the majority of the member countries of the Andean Community studied the possibility of including the pipeline mechanism in their patent laws. It was verified that the United States of America had tried to negotiate the inclusion of pipeline in the legislations of Colombia, Peru and Venezuela, through the adoption of bilateral treaties.

Colombia refused to accept such mechanism by considering the proposal a violation to the regime adopted by the Andean Community and that it goes against the principle of absolute novelty in force internationally. Peru rejected pipeline patents indicating that the mechanism goes against the novelty principle by recognizing protection to products already present in the state of the art. Venezuela, in its turn, also rejected the pipeline mechanism both for the sake of the Andean regime and for the violation of the novelty principle.

In their decision of 30 October 1996, the Andean Community Court of Justice considered that the legislation alteration formulated by Ecuador violated the Cartagena

166 Vote of the Supreme Court of Argentina, in the case: "Unilever NV vs Instituto Nacional de La Propriedad Intelectual s/ denegatória de Patentes", CS, octubre 24, 2000. Available at <http://www.csjn.gov.ar/ documentos/cfal3/toc_fallos.jsp>. Acess: November 22, 2008 
Agreement. The court understood that, by making possible the grant of a patent to an invention already patented abroad (pipeline patent), Ecuador was disobeying the universal and absolute novelty principle, and was unduly admitting a new concept of novelty only acknowledged by the country that granted it, extending a privilege to the foreign inventor beyond the circumscription to which it had originally been constituted. Moreover, the Court reinforced the understanding that the pipeline mechanism was not applicable to the common Andean regime, since the absolute and universal novelty criterion, as well as the concept of state of the art were fundamental requirements to determine the patentability of an invention. ${ }^{167}$

As made evident, the adoption of the pipeline mechanisms has been rejected by several countries and was declared invalid by the countries that adopted it for its incompatibility with the concept of absolute novelty and the priority principle adopted by international treaties regulating patent rights.

\subsection{Considerations}

Whereas some patents are in force due to this pipeline mechanism that exists due to a transitional provision in the Brazilian Patent Act, that reaches only patents filed between May 1996 and May 1997, and considering that there is a pending constitutional suit before the Brazilian Supreme Court, challenging the validity of the pipeline mechanism and all patents granted through this mechanism, it rests with the Supreme Court to rule on the constitutionality of the pipeline mechanism and all patents granted through this mechanism. 


\section{NEW FORMS OF KNOWN SUBSTANCES AND NEW USES}

The TRIPs Agreement establishes in Article 27 that any invention, whether of product or process, in all technological fields, may be patentable as long as it is new, involves an inventive step and has industrial application. It leaves at its member countries' discretion, however, the interpretation of the patentability requirements (novelty, nonobviousness and industrial application), as well as other requirements such as sufficiency of disclosure and best mode of execution, according to the domestically established public policies.

The grant of a patent implies a temporary legal monopoly of commercialization of a certain product, representing an exception to the principles of free initiative and free competition (foundations of the Brazilian State - Article l, IV, of the Brazilian Constitution $^{168}$ - as well as the country's economic order - Article 170, IV, of the Brazilian Constitution). ${ }^{169}$

As with all exceptions, the temporary legal commercialization monopoly resulting from patent protection must be interpreted with restrictions and never liberally. Thus, in case the necessary conditions for the grant of temporary legal monopoly are not fulfilled, it cannot be granted - and, if it is, it will be invalid.

As such, a restrictive interpretation of the patentability requirements must be adopted, as well as other criteria from the Patent Act, as a path to prioritize the access to a certain technology and to promote the social interests and the economic and technological development of the country.170

In the perspective of public health, patent rights must follow an even stricter standard that allows for the promotion of genuine innovation only and prevents the unjustified appropriation of matters that only contribute to limit competition and the access to existing medicine. That is why it is important that granted patents do not fail do meet all requirements and criteria provided by the Act, in accordance with domestic public policies.

168 Brazilian Constitution. Article 1. The Federative Republic of Brazil, formed by the indissoluble union of the states and municipalities and of the Federal District, is a legal democratic state and is founded on: IV - the social values of labour and of the free enterprise.

169 Brazilian Constitution. Article 170. The economic order, founded on the appreciation of the value of human work and on free enterprise, is intended to ensure everyone a life with dignity, in accordance with the dictates of social justice, with due regard for the following principles: IV - free competition.

170 Brazilian Constitution. Article 5, XXIX - the law shall ensure the authors of industrial inventions of a temporary privilege for their use, as well as protection of industrial creations, property of trademarks, names of companies and other distinctive signs, viewing the social interest and the technological and economic development of the country. 
In Brazil, the leading debate concerning the promotion of substantial innovation and incremental innovation through the patent system is linked to whether or not new uses of know products and new forms of known substances can be patented.

The issue of patentability of new uses and new forms of known substances is linked to the way a certain country decides to interpret the patentability requirements and other criteria provided by law. As mentioned before, the TRIPs Agreement allows its member countries to adopt their own interpretations of the patentability requirements - novelty, non-obviousness and industrial application - as well as of the other criteria provided by law. In short, it is not just a technical decision but, above all, a political decision about the way by which Brazil wishes to interpret and apply the patentability criteria in the country, in order to promote economic, social and technological development in accordance to the patent clause of the Brazilian Constitution (Art. 5).

\subsection{New Forms of Known Substances}

Polymorphs are, according to Soares, Correa and Lage (2010):

$[. .$.$] the existence of alterations in the crystalline arrangement of a substance$ without, however, observed modification in the structure of molecules (spatial and molecular formation). The chemical properties of different crystalline forms of a substance are identical, but the same does not occur to its physical and physical-chemical properties such as, for instance, melting point, conductivity, volume, density, viscosity, color, refractive index, solubility, hygroscopicity, stability and dissolution profile.

\section{POLYMORPHISM}

Polymorphism is the quality of a chemical substance of presenting itself in it solid state in one or more crystalline structures, resulting from the crystallization process itself. In other words, polymorphs are different crystalline forms of the same substance. Each crystalline form is distinct from the original substance (amorphous form) and may or may not have distinct properties, which can be viable for therapeutic use.

Polymorphs are intrinsic properties of molecules and cannot, therefore, be considered a human invention, consisting instead of discoveries. Discoveries are not considered inventions and, therefore, are not patentable, in accordance with Article 10, I, of the Patent Act. 
Moreover, the search for the most adequate polymorph to improve stability, solubility, bioavailability and processability of the solid form of a certain substance may already be described in the state of the art and, therefore, if that is the case, will not be characterized as non-obvious - one of the essential patentability requirements.

Some understand this as another strategy of the patent evergreening adopted by the pharmaceutical industry to indefinitely extend their patent legal monopoly.

\section{THE INDIAN SOLUTION: IMPROVEMENT OF KNOWN EFFICACY}

India has adopted a path that does not reject polymorph patenting entirely. That country which follows the middle path, deciding that if there is an improvement in the known efficacy of the substance, the resulting product may eventually be patented, if it meets the three patentability requirements, as well as the other two criteria of the social contract established by the patent system - sufficiency of disclosure and best mode.

When it comes to the process used for obtaining the polymorph, ${ }^{171}$ it is possible that it will also be eligible for patenting. However, in order to be considered patentable, this process must be new and must observe the non-obviousness requirement.

In other words, new processes for obtaining a new polymorph may eventually be patentable as long as they meet the novelty, non-obviousness and industrial application requirements, as well as the sufficiency of disclosure and best mode criteria. The resulting products, it is important to highlight, are not eligible for patenting through the reasoning mentioned above, but only the processes.

171 See Helen Miranda Silva. Avaliação da análise dos pedidos de patentes farmacêuticas feita pela Anvisa no cumprimento do mandato legal da anuência prévia. Maio de 2008. 90 f. Masters' Dissertation on Publica Health, sub-area Public Policies and Health. Fundação Oswaldo Cruz - Escola Nacional de Saúde Pública Sérgio Arouca - ENSP. Rio de Janeiro, 2008. 


\section{HARMFUL CONSEQUENCES OF PATENTING NEW FORMS OF KNOWN SUBSTANCES}

For public health and the generic medicines industry, the patenting of new forms of known substances may represent an irresponsible extension of the temporary legal monopoly of patents, since it consists of the patenting of a mere new arrangement of an already known active substance. It would mean the successive patenting of the same active ingredient (an extension of the patent beyond the initially granted 20 years) or the attempt to grant patents to substances already in the public domain.

The patenting of new forms of known substances may result in: (a) the extension of the patent legal monopoly for certain active substances; (b) a delay or difficulty in the introduction of new generic medicines in the Brazilian market; and (c) problems with the access of the population to medicines and treatments, as the extension of patent monopolies keeps prices unduly elevated, resulting in purchasing problems for the National Health System (SUS). Thus, the granting of trivial patents can introduce serious hindrances to the politics of innovation and technological modernization in course, in addition to directly harming accessibility to medicines and important agricultural materials such as crop protection chemicals and seeds.

The recognition of patentability to new crystalline forms of older substances already in the public domain or not would go against the development policy adopted by Brazil.

Brazil is not the only one beginning to realize that those kinds of inadequate patenting attempts are harmful to health and to technological, economic and social development; but also the Ministries of Health of Chile, Argentina, Uruguay and Paraguay, which, along with the Brazilian Ministry of Health, have signed the Agreement "Patentability Criteria, Access to Medicines and Public Health" as it is their understanding that

"the fulfillment and application of patentability criteria in our region raises concerns due to the proliferation of patent applications on matters that do not properly constitute an invention or are marginal developments. That those difficulties have been highlighted in several studies pointing to the negative effects to access to medicines and public health in the granting of patents of medicines based on these types of claims." ${ }^{172}$

This is the understanding sanctioned by the World Health Organization - WHO on the Guidelines for the examination of pharmaceutical patents: developing a public health perspective, elaborated by Dr. Carlos Correa, Professor at the University of Buenos Aires (Correa, 2007, p. 10-11). 


\section{Chart - Polymorph patents}

Some therapeutically active ingredients present polymorphic forms, that is, they may exist in different physical forms (as amorphous solid and/or in different crystalline forms), which may have different properties more or less pharmaceutically significant (such as solubility and therefore bioavailability). Polymorphism is a natural property: polymorphs are not 'created' or 'invented'; they are discovered normally as part of routine experimentation related to drug formulation. They result from the conditions under which a compound is obtained. Any compound that presents polymorphism will naturally tend to its more stable form, even without any human intervention.

$[\ldots]$

Independent patent applications on polymorphs have become increasingly frequent and controversial, as patents thereon can be used to obstruct or delay the entry of generic competition. Polymorphs can be deemed within the prior art - and therefore non-patentable - if they are inevitably obtainable following the process of the basic patent on the active ingredient. Moreover, the possibility of discovering different crystals is obvious when polymorphism is found. $[\ldots]$

Recommendation: Polymorphism is an intrinsic property of matter in its solid state. Polymorphs are not created, but found. Patent offices should be aware of the possible unjustified extension of the term of protection arising from the successive patenting of the active ingredient and its polymorphs, including hydrates/solvates. Processes to obtain polymorphs may be patentable in some cases if they are novel and meet the inventive step standard (emphasis added).

Source: CORREA, 2007. "Guidelines for the examination of pharmaceutical patents: developing a public health perspective."

The example of the antiretroviral drug Ritonavir, which is in public domain in Brazil, shows us in practice the effects of polymorph patents. There are patent applications for polymorphs of the Ritonavir active principle that, if granted, would hinder the production of the corresponding generic medicines.

The United Nations Conference on Trade and Development - UNCTAD launched guidelines in $2011^{173}$ about how intellectual property rights can be used to stimulate the production in the pharmaceutical field in developing countries. While approaching the theme, UNCTAD highlights that this discussion does not apply only to polymorphs, but includes also other forms of small structural modifications in known substances that may consist of variations in the formulation of active ingredients combined among themselves or with other elements. The following are examples that also characterize

173 UNCTAD - UNITED NATIONS CONFERENCE ON TRADE AND DEVELOPMENT. Using Intellectual Property Rights to Stimulate Pharmaceutical Production in Developing Countries: A Reference Guide. New York and Geneva, 2011. 
evergreening strategies and that must, therefore, be avoided: formulations, chemical intermediates, pro-drugs, isomers, salts, and combinations, among others. ${ }^{174}$

Those small variations produce the so-called me too drugs, with therapeutic effects that differ little or nothing from other existing drugs. Even then, in countries with weaker patentability criteria, those variations may result in new patents. In those cases, the manufacturers of generic medicines that would be able to enter the market when the first patent expired are not able to do so because of a patent that protects modified versions of the same product. ${ }^{175}$

Thus, UNCTAD recommends a thorough analysis of the non-obviousness requirement (one of the patentability requirements) so that patents for this kind of claims cannot be granted. ${ }^{176}$ In the United States, the Federal Trade Commission has been criticizing that country's patent office for not paying enough attention to the problem and adopting weak patentability criteria that yield in anti-competition effects. ${ }^{177}$

The line of reasoning that defends that the national industry could be harmed in case polymorph patents are not allowed is used with a certain frequency. Those who defend this argument maintain that developing countries (Brazil included) should only be holders of incremental patents, considering our still limited capacity for innovation. However, it is worth stressing that, if the grant of polymorph patents was technically possible, they would only be granted to the holder of the first patent, as other patents would constitute an infringement of the original patent by being actually the same substance only with a different arrangement.

Thus, even if there was any kind of advantage for the encouragement of national industrialization in patenting new forms of known substances, if this kind of patenting was authorized, it would only bring about the consolidation of the legal monopoly of companies that already hold patents for amorphous substances; most of them transnational companies.

According to this reasoning, the Brazilian Association of Chemical and Biotechnology Industries and its Specialties (Abifina) ${ }^{178}$ has been adopting the opposite attitude towards the patenting of new forms of known substances of chemical molecules by understanding that those patents do not meet the requirements of novelty and nonobviousness. Accordingly, the Oswaldo Cruz Foundation (FIOCRUZ) as well as

\footnotetext{
174 Idem, p. 77.

175 Idem.

176 Idem.

177 Federal Trade Commission (FTC). To promote innovation: the proper balance of competition and patent law policy. 2003.

178 Abifina, Comitê de Propriedade Industrial, Patenteabilidade de polimorfos. 2007.
} 
ANVISA have also adopted a contrary position towards the patenting of new forms of known substances. ${ }^{179}$

\subsection{New uses}

A similar discussion to that of new forms of known substances, however more relevant because it reaches a higher number of products, is that of new use patents. The grant of new use patents represents a duplication of rights and fits the cited evergreening strategies - the illegal and indefinite extension of patents.

The first medical use is defined as a new use, as a medicine, of an already existing product that had never been used in the medical field. The second medical use (which can include a third, fourth or fifth use, and so on) constitutes a new therapeutic application of a new compound that already has a therapeutic use. ${ }^{180}$

\section{NEW USES ARE MERE DISCOVERIES}

New uses of a known product are, in reality, discoveries of a new effect of this product, given that nothing has been altered in the product; there is no sense in talking of a new invention, but only a new use for an existing invention.

Patents for second medical or therapeutic use seek the protection for a new medical or therapeutic use of a known compound with application in the medical field. This category encompasses:

1. New therapeutic applications for a registered medicine;

2. New therapeutic application for a compound in different formulations, presentations and dosage from the registered medicine; and

3. New therapeutic application of compounds with known biologic activity but that have not reached the market or have not been considered promising for the first appointed therapeutic use.

The new use patent becomes a mechanism to inadequately and illegally extend a patent term for a reference medicine.

From the moment the 20-year term of the patent of a reference or innovative medicine ends, the right guaranteed by TRIPs comes into force, which allows other pharmaceutical

179 See participation in the cycle of technical discussions conducted by the Brazilian Patent Office. Available at: https://www.inpi.gov.br/menu-esquerdo/patente/discussoes-tecnicas/index_html/. Access: 3 April 2011.

180 JANNUZZI, Anna Haydée Lanzillotti; VASCONCELLOS, Alexandre Guimarães; SOUZA, Cristiana Gomes de. Especificidades do patenteamento no setor farmacêutico: modalidades e aspectos da proteção intelectual. Cadernos de Saúde Pública. Rio de Janeiro, 24(6): 1205-1218. June 2008. 
companies to enjoy the possibility of manufacturing and commercializing the product with an expired term that can therefore be commercialized such as, for instance, the generic medicine.

Companies that are patent holders of reference or innovative medicines, with the aim of keeping the commercial monopoly of the product and/or making the introduction of competition more difficult, application patent rights for new processes of synthesis, new forms of known substances, pharmaceutical compound, second medical use and so on, seeking to appropriate the technology regarding that medicine - in clear dishonor of competition principles.

The possibility of granting new patent rights for a product with the same active ingredient will most likely interfere with the entry of generic medicines in the market.

A different line of thought that, however, does not appear to us more adequate to the present degree of development in Brazil, argues in favor of the patenting of new uses because they claim that such patents would encourage innovation, as there has been a decrease in the discovery of new molecules over the last decade. As evident, one affirmation does not seem to lead to the other. It is, in fact, the opposite. The fact that there has indeed been a considerable decrease in the discovery of new molecules only reinforces that true innovation must be encouraged instead of the unjustified patenting of substances that are not new and do not have industrial application.

\section{REPORT BY THE GOVERNMENT OF THE UNITED KINGDOM WARNS AGAINST THE PATENTING OF NEW USES}

Encouraging the patenting of new uses would end up perpetuating and consolidating a system that has not been innovative in over a decade - exactly the opposite of the goals of the patent system. ${ }^{181}$

The CIPR Report by the Government of the United Kingdom is clear: "[...] we caution against developing countries simply taking over from the comparatively recent European jurisprudence the counter-intuitive notion that a product may be regarded as new, if a new use is identified for it. Such an approach is not required by TRIPS [...]." ${ }^{\prime 182}$

The line of thought that defends new use patents argues that, as there is no expressly stipulated contrary provision on TRIPs, a sole medicine may have diverse innovations

181 See chart "Crise de Inovação da Indústria Farmacêutica Mundial", chapter 12.1, infra.

182 See United Kingdom, Commission on Intellectual Property Rights (CIPR), Integrating Intellectual Property Rights and Development Policy, London, 2002. 
depending on the desired goals. In that regard, the second medical use would be eligible for patenting if meeting the patentability requirements defined on the Patent Act.

\section{THE THREE PATENTABILITY REQUIREMENTS}

The three requirements are: (a) novelty, that is, it is imperative that the invention be different from everything made accessible to the public prior to the filing date of the patent application, either by oral or written description, by use or any other means, in Brazil or abroad; (b) non-obviousness, by which must be understood that the invention cannot be deemed evident or obvious by a field expert, and e (c) industrial application, which is the possibility for the invention to be used or produced in any kind of industry. In addition to the traditional requirements, there are other two criteria that are part of the social contract established by the patent system to create a balance between private interest by the patent holders and public interest to access to the patented technologies: (d) sufficiency of disclosure, which demands that the filed product or process patent be clear and sufficiently descriptive so that a person skilled in the art is fully able to produce the patent and, finally, (e) the best mode, which demands that the best mode of execution of the invention is expressly detailed under risk of invalidation the expressly detailed description of the best mode of execution of the invention at the risk of the patent being deemed invalid. ${ }^{183}$

Another argument that goes against the patenting of new uses is that they are nothing but mere discoveries, and discoveries are not patentable according to the Brazilian law (Art. 10, I of the Patent Act). It is important to mention that there is no exhaustive list of what is considered a discovery by law, as that would make no sense whatsoever.

\section{THERAPEUTIC METHODS}

The claim for a new use patent is aimed at protecting the effect of the compound in the organism and not the product in itself or its manufacturing methods. In that sense, such claims are substantially equivalent to claims to treatments or therapeutic methods, which are expressly excluded from patenting in accordance to the Art. 10 VIII of the Patent Act.

This is the understanding sanctioned by the World Health Organization - WHO, already mentioned in the Guidelines for the examination of pharmaceutical patents:

183 Novelty is provided in Articles 11 and 12; non-obviousness (inventive activity), in Art. 13, combined with Articles 11 and 12; industrial application is provided in Art. 15; sufficiency of disclosure, in Art. 24, and best mode of execution in Art. 24, all articles from Act 9.279/96. 
developing a public health perspective elaborated by Dr. Carlos Correa, Professor at the University of Buenos Aires.

\section{Chart - Use-related claims, including second indications}

Patenting of the medical use of a product, including first and second indications of a known medicinal product has become common practice in the pharmaceutical field. According to a literal interpretation of the TRIPS Agreement, which only obliges to grant patents over products and processes, Members should be under no obligation to grant use claims, including second indications.

[...] the European Patent Convention and the law of some countries allow for the patenting of the first pharmaceutical indication of a known product. Second indications are accepted under European jurisprudence and in other countries when framed in accordance with the so called 'Swiss" claims. However, the patenting of a new use of a known product including, in particular, second indications, expands the scope of protection inconsistently with the novelty requirement.

In addition to the lack of novelty, there are other possible objections to the patentability of second indications:

- there is no industrial applicability, since what is new is an identified effect on the body, not the product as such or its method of manufacture;

- a patent covering the second medical indication of a known product is substantially equivalent to a patent over a method of therapeutic treatment.

Admitting the patentability of second indications extends the protection of pharmaceuticals to cases where no new product has been developed. Many countries reject claims over such indications.

Recommendation: Claims relating to the use, including the second indication, of a known pharmaceutical product can be refused, inter alia, on grounds of lack of novelty and industrial applicability (emphasis added).

Source: CORREA, 2007. "Guidelines for the examination of pharmaceutical patents: developing a public health perspective"

UNCTAD (2011), in their above mentioned guidelines on pharmaceutical patents, highlights that the patent right for a new use of a known product adds a new layer of exclusive rights to the same chemical substance, consisting on a classic case of evergreening and considerably extending the period during which generic manufacturers will not be able to manufacture the protected substance. Thus, patent applications based in new uses can be denied, since there is lack of novelty (one of the patentability requirements) as the product is already known. Moreover, process patent applications can be denied based on the exclusion of patentability of therapeutic methods. ${ }^{184}$ 
Thus, whether it is for their status as discoveries and therapeutic methods or for their non-compliance with the novelty or industrial application requirements, patents of use and new use must not be protected as new inventions. Admitting their patentability means unduly extending protection to cases in which nothing new has been developed, which favors the patent holder to the detriment of competition and the national public interest, in direct confrontation of the Brazilian Constitution (Art. 5, XXIX).

Some have argued that new use patent would consist of simpler technological innovations and, therefore, could be of interest to Brazil. Others argue that empirically it is verifiable that new use patents are usually filed by the holders of the original patents, a situation that renders the effect of new use patents negative to Brazil by resulting on undue extension of patents.

By unduly extending the temporary legal monopoly of a previous patent, the new use patent hinders the production of generic medicines, harming the population and the federal, state and municipal bodies in charge of the free distribution of those medicines. They would also pose a threat to companies waiting for the patent to come to term in order to enter the generic market for that medicine. All to the detriment of public health, competition laws, as well as the goals of the patent system provided by the Brazilian Constitution.

Moreover, the WTO does not mandate patent rights for new forms of known substances or new use patents. ${ }^{185}$ According to Milena Barbosa de Melo and Lucília Napoleão Barros $^{186}$, there is no uniformity regarding new use patents, as illustrated by comparing legislations:

INDIA: Does not admit new uses. The India Patent Act, in accordance to a 2005 review, in Article 3(d), does not consider an invention the mere discovery of any new property or new use of a known substance, or the mere use of a known process, machinery or apparatus, unless this known process results in a new product or employs at least one new reagent. ${ }^{187}$

ANDEAN COMMUNITY: Does not admit new uses. In their legislation pertaining the subject, the 486 Declaration in its Article 21 is very exhaustive regarding the restrictions over the new use mechanism, stating that products and processes already patented and

185 OLIVEIRA, Rodrigo Borges. A patenteabilidade do segundo e dos posteriores usos médicos no Brasil, PhD thesis, PPED-IE-UFRJ, 2012.

186 MELO, Milena Barbosa de. BARROS, Lucília Napoleão. Os Direitos de Propriedade Intelectual e o Evergreening. In: Âmbito Jurídico, Rio Grande, 93, 01/10/2011.

187 See Feroz ALI KHADER, The Law of Patents - With a Special Focus on Pharmaceuticals in India, LexisNexis Butterworths, 2007, pp. 69-86. 
included in the state of the art cannot be the subject of new patents only for yielding a different use from the originally contemplated by the initial patent.

ARGENTINA: Does not admit new uses. Products elaborated according to a preexisting formula are not eligible for protection. The novelty requirement, then, is not met, as the compound was already known for medical use, as well as the manufacturing process of the medicine.

CHINA: China, unlike Argentina, admits product protection for new use by means of the Swiss formula.

JAPAN: Patenting of a new use exclusively dependent on the examination will be admitted when the state of the art indicates that the new medical use is different from the original. Therefore, in order to be granted legal protection, the medicine must have a clearly differentiated application in the applicable situations. If the original medicine is used in the treatment of malady " $\mathrm{A}$ " and, after the discovery of a new use, the medicine begins to be employed in the treatment of malady "B", it characterizes innovation and, therefore, the medicine will have its new legal protection - which calls for clear legal gymnastics and artifices.

Other countries adopt the following system concerning the patenting of new uses, according to Maria Thereza Wolff and Paulo de Bessa Antunes ${ }^{188}$ :

UNITED STATES: The United States do not accept claims to use; however, they accept claims of method and process. Thus, every claim to use that is put forth is rejected and it is determined that they be transformed, for instance, in claims to method - for instance, therapeutic methods; which are not prohibited in that country.

EUROPEAN UNION: EPC (European Patent Convention) - Art. 54(5) says, regarding novelty: "Paragraphs 2 and 3 shall not exclude the patentability of any substance or composition, comprised in the state of the art, for use in a treatment of the human or animal body by surgery or therapy and diagnostic methods practiced on the human or animal body, provided that its use for any such method is not comprised in the state of the art". Articles 52(1), 52(4), 54(5) and 57 are subject to the Vienna Agreement about the ruling in Articles 4, 31, 32 of "second medical indication".

GERMANY: The German Patent Act, in what concerns novelty, provides in its Paragraph 9, item II, 6, that the patentability of an invention of use is not excluded when employing a new substance. In addition to the patent protection for the first medical indication, the legislation also allows for the patenting of a claim to use of second or

188 WOLFF, Maria Thereza. ANTUNES, Paulo de Bessa. Patentes de Segundo Uso Médico. In: B. Cient. ESMPU, Brasília, a. III - n. 13, p. 115-131 - Oct./Dec. 2004. 
further medical indications, that is, the use of a known medicine in the treatment of other diseases.

SOUTH KOREA: The second medical use of a pharmaceutical product receives wideranging legal protection as long as it meets the patentability requirements normally provided by law.

\section{"ONE SIZE DOES NOT FIT ALL: DIFFERENT TREATMENTS ARE THE PRINCIPLE OF JUSTICE"}

It becomes evident that the most advanced countries in the chemical field are nowadays issuing second medical use patents one way or the other, since they already have sufficient knowledge in the area. We see fit to remember, however, that many of those countries were not even protecting pharmaceutical products until recently, when they did not yet have technological ability in the chemical field. It was not until their capacitation in the chemical field that they began to change their laws to appropriate those new uses. In fact, some countries such as Holland even abolished their patent system entirely as they understood that it was detrimental to their economy. ${ }^{189}$

The one size does not fit all motto reminds us that a certain regulation, for a certain country, will not necessarily be beneficial to another country, especially if they have different degrees of development in the area under comparison. Thus, Brazil should not adopt similar regulations to other countries, if our technological development in a certain area is not sufficiently advance to result in more social and economic benefits than losses to the country.

Thus, processes of copy and imitation, in case Brazil is not internationally obligated to adopt a certain regulation (such as issuing new use patents, for instance), are essential to the development of technological ability, with resulting social and economic benefits for the country. In fact, it was through copy and imitation that countries that are presently developed manage to evolve.

In that regard, the Gowers Review by the Government of the United Kingdom is emphatic: "The economic evidence and, in particular, the history of currently developed countries suggest that a single one-size-fits-all approach is inappropriate. (...) Given that different IP regimes are more appropriate at different stages of development, it would make sense to allow individual nations to choose when to strengthen their IP regimes, rather than to seek to enforce a certain perspective."

189 The Netherlands abolished its patent system entirely from 1869 to 1910 . See Adam B. JAFFE and Josh LERNER, Innovation and Its Discontents - How our Broken Patent System is Endangering Innovation and Progress, and What to Do About it. Princeton, 2004, pp. 86-90. 
The facilitated granting of polymorph and new use patents goes against the Agreement between Mercosur Ministers of Health, ${ }^{190}$ as mentioned above, as well as the text of the Doha Declaration on the TRIPs Agreement and Public Health, produced in the WTO's ministerial conference of 2001. Similarly, the World Health Organization resolution WHA61.21, approved at the 61 ${ }^{\text {st }}$ World Health Assembly contemplates the principles by which the intellectual property rights cannot and must not hinder member countries from taking measures for the promotion of public health, which would be directly challenged in case of inappropriate extension of the term or legal monopoly of a chemical substance of importance to public health.

\section{ARGENTINA'S PATENT GUIDELINES}

Argentina, in accordance to the understanding adopted by Mercosur and other multilateral bodies mentioned above, has altered, in May 2012, their guidelines for patent examination in the chemical-pharmaceutical field. ${ }^{191}$ Concerning new uses, those are considered treatment methods, and, therefore, are not eligible for patenting. The same understanding is adopted in regard to new dosages and combinations. As for polymorphs (as well as pseudo-polymorphs - hydrates and solvates), the new guidelines exclude the possibility of patenting by not considering them new inventions, since they are intrinsic properties of matter - therefore, mere discoveries. They also exclude the possibility of patenting processes for obtaining new forms of known substances, as they constitute routine experiments in the field.

The new Argentinian guidelines also encompass other forms of variations of a single substance such as salts, esters, amides, enantiomers and other derivatives, excluding the possibility of patenting as the substance is already known. New formulations and compounds are also excluded from patentability as they are considered obvious and, therefore, do not meet the non-obviousness requirement.

Moreover, Argentinian guidelines approach the theme of Markush claims, highlighting the need to restrict patent rights only for claims that are in fact unveiled in the descriptive report of the application. They also explain that the so-called "selection patents" cannot in fact be patented as they consist of knowledge already unveiled in the state of the art, even if there are properties not previously shown.

Argentina, then, embraced their political autonomy and validated the safeguards of the WTO TRIPs Agreement by adopting clear guidelines for patent examinations that are in line with their actual stage of technological development in the pharmaceutical-chemical field, thus implementing stricter interpretations of the patentability requirements as a way of protecting public health as well as the economic and technological development of that country. 


\subsection{The Brazilian Patent Office's examination guidelines, and the decision of the Inter- ministerial Group on Intellectual Property}

In spite of the above exposition, the "Guidelines for the examination of patent applications in the biotechnology and pharmaceutical fields filed after 31 December 1994" before the Brazilian Patent Office do admit the granting of new forms of known substances, and of use claim patents. The examination guidelines presently in force, undergoing review, were published in 31 December 2002 in the Industrial Property Review (Revista da Propriedade Industrial - RPI) no. 1669.

In June 2007, the Brazilian Patent Office organized a cycle of technical debates aimed at discussing the patentability conditions of new forms of known substances to support the new examination guidelines in the pharmaceutical field.

The Brazilian Patent Office's guidelines presently in force do not allow the grant of patents of first medical use, as it is their understanding that this type of application does not have the novelty factor, according to the Article 11 of the Patent Act ${ }^{192}$, as it is about a known compound (Article 2.39.2.1, the Brazilian Patent Office guidelines ${ }^{193}$ ). Nevertheless the Patent Office's Guidelines allow the grant of second medical use patents, chiefly by means of a legal device forged in Europe known as the "Swiss claim". ${ }^{194}$ Through this artifice, use claim patents become equivalent to process patents.

In regard to new forms of known substances, the Guidelines presently in force are remiss, but the Brazilian Patent Office has been accepting the granting of patents for new crystalline forms. ${ }^{195}$

Parallel to the debate cycle, a specialist group from the Brazilian Patent Office has gathered for a technical discussion of the patentability of new forms of known

192 Patent Act, Article 11 - Inventions and utility models are considered to be new when not included in the state of the art. $\S 1$ - The state of the art comprises everything made accessible to the public before the date of filing of a patent application, by written or oral description, by use or any other means, in Brazil or abroad, without prejudice to the provisions of articles 12, 16 and 17. § 2 - For the purpose of determining novelty, the whole contents of an application filed in Brazil, but not yet published, will be considered as state of the art from the date of filing, or from the priority claimed, provided that it is published, even though subsequently.

193 the Brazilian Patent Office Examination Guidelines. 2.39.2.1 Claims such as: a) Product X characterized by being used as medicine. b) Product $\mathrm{X}$ characterized by the fact that it is for the treatment of disease $\mathrm{Y}$. They are not granted because its object does not present novelty, because, as defined in (i) above, it is a known product, which obviously is not new within the meaning of Article 11. Note that here one deals with inventions of new use, i.e., one assumes that it is an already known product.

194 Swiss formula or Swiss claim is the claim to use a known pharmaceutical compound for the production of pharmaceutical compositions in which the compound has previously unknown therapeutic activity. The claim is made to encompass the discovery of a further medical use of a known substance. "Aspirin" is a classic example: it was first marketed as an analgesic, but then it was discovered that it has also blood clearance properties. See Feroz ALI KHADER. The Law of Patents - With a Special Focus on Pharmaceuticals in India.LexisNexis Butterworths, 2007, p. 76.

195 Soares, Jaqueline Mendes et al. op. cit. p. 47. 
substances in the pharmaceutical field. This group elaborated a preliminary document that, after becoming available for admission of technical contributions by means of an e-mail address from the Brazilian Patent Office, has been adopted as a proposal for examination guidelines for patent applications in the pharmaceutical field regarding new forms of known substances. ${ }^{196}$

By means of the new proposed examination guidelines, the Brazilian Patent Office considers that new forms of known substances may have novelty and non-obviousness, as long as they meet certain criteria. They also consider that some pharmaceutical compounds with new forms of known substances may be eligible for patenting. The guidelines also make possible the grant of patents for new processes for obtaining new forms of known substances.

It is paradoxical for the Brazilian Patent Office to consider that new forms of known substances meet the non-obviousness criterion while the CIPR Report by the Government of the United Kingdom clarifies that, when the standard for non-obviousness is low and, for instance, allows the patenting of new forms of known substances, if applied to developing countries, this standard becomes detrimental to research. And the same study goes on to recommend measures to developing countries such as Brazil: "The objective of any standard should be to ensure that routine increments to knowledge, involving minimal creative input, should not generally be patentable."197

\section{THE BRAZILIAN INTER-MINISTERIAL GROUP ON INTELLECTUAL PROPERTY ISSUED A RESOLUTION AGAINST THE PATENTING OF NEW USES AND NEW FORMS OF KNOWN SUBSTANCES}

Considering the different views and the importance of the theme for the social, economic and technological development in the country, the Inter-ministerial Group on Intellectual Property ${ }^{198}$, which is the organism in charge of harmonizing the positions of the Federal Executive Branch and its bodies about patent and related rights, has issued a decision in December 2008 expressing a position by the Federal Government contrary to the extension of patent protection to new uses and new forms of known substances. the Brazilian Patent Office, however, expressed that, in case such impediments came into force, an alteration in the Patent Act would prove necessary so that they could be contemplated.

196 Idem. p. 45.

197 See United Kingdom, Commission on Intellectual Property Rights (CIPR), Integrating Intellectual Property Rights and Development Policy, London, 2002.

198 MDIC, Grupo Interministerial de Propriedade Intelectual divulga resumo da ata de reunião. 19/12/2008. Disponível em: http://www.mdic.gov.br/arquivos/dwnl_1229696044.pdf, consultado em 11 de abril de 2011. 
It is exactly because of the understanding adopted by the Brazilian Patent Office, allowing the patent protection of new use and polymorph claims to the detriment of the public interest and regardless of the contrary position against it expressed by the Federal Government, that the present debate is still necessary.

\subsection{Legislative proposal}

By not meeting the patentability requirements of novelty and non-obviousness, new use patents cannot and must not be granted. In this regard, the Brazilian Patent Office guidelines must observe the strict novelty and non-obviousness criteria, in order to avoid disobeying the legislation in force. The same applies to new forms of known substances.

Strictly speaking, there would not be the need for law alterations to prevent new use and polymorph patents from being granted. However, keeping in mind the position adopted by the Brazilian Patent Office making possible granting those patents, even going against the Government's decision, which is expressly contrary to those patents, as conveyed by the Inter-ministerial Group on Intellectual Property, we understand that an alteration in the legislation can prove enlightening.

There are two bills before the Chamber of Deputies on the issue: Bill H.R. 2511/2007, sponsored by Congressman Fernando Coruja (PPS/SC), and Bill H.R. 3395/2008, by Congressmen Paulo Teixeira (PT/SP) and Dr. Rosinha (PT/PR).

Despite being in line with the position defended in this Report, the original text proposed by the bills was not the most adequate for the issue as it incurred in conceptual deficiencies regarding the prohibition of new use patents - which is also valid for new forms of known substances. That is because, by including a new item in Article 18 of the Patent Act, which concerns non-patentable inventions, one supposes that there is in fact an invention but it is not, however, eligible for patenting.

As shown above, the claims to use, as well as new forms of known substances, are not inventions but mere discoveries. That is why they cannot be protected by means of a patent. Still, the text proposed by Bill 2511/2007 reinforced the argument adopted by some sectors of society according to which the Patent Act should expressly provide everything that is not considered patentable, establishing an exhaustive and categorical list.

However, we do not consider that the best legislative technique, having in mind that it is impossible for the legislator to predict everything that could be claimed in a patent application.

In that regard, the substitute in the Commission of Social Security and Family (CSSF), which deals with the issue by means of Article 10 of the Patent Act (about what the law does not accept as invention) instead of introducing the theme on Article 18 of the same 
Act, is indeed more appropriate to the goals of the above mentioned Bills, by the Patent Act and the Brazilian Constitution.

Based on the research undertaken in the scope of this Report, we understand that the best language is:

Art. 10. It shall not constitute an invention or utility model:

$\mathrm{X}$ - any new property or new use of a known substance, or the mere use of a known process, unless this known process results in a new product;

$\mathrm{XI}$ - new forms of known substances that do not result in an improvement in the known efficacy of the substance.

Sole paragraph. For the purposes of this Article, salts, esters, ethers, polymorphs, metabolites, pure form, size of particles, isomers, mixtures of isomers, complexes, combinations and other derivatives of a known substance shall be considered the same substance, unless they significantly differ in terms of properties regarding efficacy.

With the proposed alteration, the Patent Act will simply make explicit that new claims to use of known products and processes; as well as new forms of known substances that do not result in the improvement of the known efficacy of the substance, are mere discoveries and, as such, cannot be considered inventions - rendering them ineligible, therefore, to be patented.

Independently of the express exclusion suggested above, new uses and new forms of known substances lack patentability requirements and, therefore, cannot be patented.

\subsection{Recommendations}

\section{a) To Congress:}

Approve Bill H.R. 5402/2013 in order not to allow (i) patents for new forms of known substances that do not result in the improvement of the known efficacy of the substance, for they are mere discoveries and lack inventive step, and (ii) patents that claim any new property or new use of a known substance (new uses), for they are mere discoveries, lack novelty and industrial application, and for they are mere therapeutic methods, in order to promote greater legal certainty and to respect the Constitutional patent clause (see Art. 3 of Bill 5402/2013, attached, that amends Art. 10 of the Patent Act).

\section{b) To the Executive Branch:}

Immediately implement the Inter-ministerial Group on Intellectual Property (GIPI) resolution mentioned in this chapter in order to tackle the issue appropriately and to eliminate the present legal uncertainty. 


\section{b.2) to the Brazilian Patent Office (INPI):}

b.2.1) reject patents for new forms of known substances that do not result in the improvement of the know efficacy of the substance, as they are mere discoveries and lack inventive step;

b.2.2) reject patents that claim any new property or new use of a known substance (second and further uses), as they are mere discoveries, lack novelty and industrial application, besides being mere therapeutic methods; and

b.2.3) clearly indicate in the examination guidelines that it shall not be patentable (a) any new properties or uses of a known substance, as well as (b) new forms of known substances provided the latter do not result in improvement of the known efficacy of the substance.

\section{b.3) to the Sanitary Agency - ANVISA:}

Duly observe, in the prior consent procedures, the three patentability requirements, as well as the other two criteria established by the patent system - sufficiency of disclosure (enablement) and best mode.

\section{b.4) to the Competition Agency - CADE:}

Tackle anti-competitive and abusive practices caused by patents claiming any new properties or uses of a known substance, as well as new forms of known substances that do not result in the improvement of the substance's known efficacy. ${ }^{199}$ 


\section{THE SANITARY AGENCY'S (ANVISA) PRIOR CONSENT}

Ever since 1999, for a patent in the pharmaceutical field to be granted in Brazil, it must first get prior consent from the National Sanitary Agency (Agência Nacional de Vigilancia Sanitária - ANVISA), first by means of the Provisional Act, and then through the Patent Act. However, some issues arose regarding ANVISA's role in the exercise of previous consent, which has been weakening this institute of protection of public health and the development of the country. We believe that some amendments to the legislation may help eliminate any remaining doubt as well as strengthen ANVISA's participation in the process of granting patents to the benefit of social, economic and technological development in Brazil.

ANVISA's prior consent is a measure to protect public health and is in perfect accordance to the international patent rules. This measure is corroborated by the principles of the TRIPs agreement established in Articles 1 and $8^{200}$ and the WTO's dispute settlement body has already confirmed that countries are allowed to institute differentiated mechanisms of analysis of patent applications in certain fields, in order to implement national policies, and that it is not characterized as violation to the non-discrimination principle feature in Article 27 of TRIPs. ${ }^{201}$

It became mandatory for pharmaceutical patent applications to undergo analysis by ANVISA ever since the institution of Provisional Act 2006/1999, which created the prior consent mechanism. Prior consent was consolidated by Law no. 10196, of 2001, which amended Article 229 of the Patent Act - including item C:

\section{Article 229-C, Patent Act}

The granting of patents for pharmaceutical products and processes shall depend on the prior consent of the National Sanitary Agency - ANVISA.

Due to the essential nature of pharmaceutical products as well as the impact of a patent in the access to those goods, the Brazilian government understood that such a relevant matter deserved the most careful and technical examination available to the government.

200 TRIPs Agreement, Article 1. Members shall give effect to the provisions of this Agreement. Members may, but shall not be obliged to, implement in their law more extensive protection than is required by this Agreement, provided that such protection does not contravene the provisions of this Agreement. Members shall be free to determine the appropriate method of implementing the provisions of this Agreement within their own legal system and practice. Article 8 - Principles - 1 - Members may, in formulating or amending their laws and regulations, adopt measures necessary to protect public health and nutrition, and to promote the public interest in sectors of vital importance to their socio-economic and technological development, provided that such measures are consistent with the provisions of this Agreement.

201 WORLD TRADE ORGANIZATION. WT/DS114/R, March 17, 2000, paragraph 7.92. Beyond that, it is not true that Article 27 requires all Article 30 exceptions to be applied to all products. Article 27 prohibits only discrimination as to the place of invention, the field of technology, and whether products are imported or produced locally. Article 27 does not prohibit bona fide exceptions to deal with problems that may exist only in certain product areas. Available at www.wto.org/english/tratop_e/dispu_e/7428d.pdf. 
The explanatory statement for the provisional act that instituted prior consent makes it evident that its purpose is to establish collaboration between ANVISA and the Brazilian Patent Office aimed at a more efficient, and of superior quality, technical analysis.

8. As for Article 4, the granting of patents - of both process and product - by the Brazilian Patent Office will only be granted with the prior consent of the National Sanitary Agency (ANVISA). This joint work by the Brazilian Patent Office and ANVISA will ensure better technical standards in the decision process for pharmaceutical patents, similar to procedures employed by the most advanced systems of patent control and sanitary surveillance in force in more developed countries. (Inter-ministerial explanatory statement no. 92/99, for Provisional Act no. 2006/99)

The procedure of prior consent by ANVISA was regulated by Resolution RDC no. 45, of 23 June 2008, of the Collegiate Board of the National Sanitary Agency:

Article 3. The procedure of prior consent will occur as the Brazilian Patent Office forwards processes to ANVISA for knowledge and examination, may the Agency conclude to consent or not consent, by means of a substantiated decision.

Article 4. Upon receipt of patent applications forwarded by the Brazilian Patent Office, ANVISA will undertake its analysis as to consent evaluating the compliance of patentability requirements and other criteria established by law, in view of decisions embodied in technical opinions issued by the competent organizational unit within the Agency.

$\S 1$ During the examination, the applicant shall submit to ANVISA, whenever applicationed by the requirement:

I - documents necessary to regularize the process and examination of the application;

II - objections, searches for previous registrations and results of examination for the granting of corresponding applications in other countries, where priority is claimed, and

III - other documents necessary to answer questions arising during the examination.

$\$ 2$ By the end of the analysis of this Resolution, interested parties may file documents and information that support the examination by ANVISA.

Art. 5 When the technical opinion favors, in a preliminary basis, non-consent or formulates any demands, the applicant or their attorney will be notified through registered letter, to respond, within ninety days, counting from the date of the official notification or confirmation by the interested party.

$\$ 1$ When the demand is answered, even if not met, or its formulation is challenged, whether or not there was a response about patentability or framing, ANVISA will proceed to the examination.

Art. 6 When the ANVISA examination opts for consent, the application will return to the Brazilian Patent Office for the conclusion of the patent grant procedure. 
Art. 7 Decisions relative to the conclusion of the examination for prior consent will be published in the Official Gazette.

$\$ 1$ The decision denying consent to the application will be eligible for appeal to the Collegiate Board of ANVISA for a 60-day term [...].

$\$ 2$ After the appeal is tried, the application will return to the Brazilian Patent Office for the conclusion of the patent grant procedure.

\section{ANVISA RESOLUTION (RDC NO 45/2008)}

[...] Brazil ended up with a dual examination system in the area of pharmaceutical patents that looks something like this: a) the Brazilian Patent Office receives and examines a patent application; $\mathbf{b}$ ) if the Brazilian Patent Office determines that the patent should not be granted, then it is rejected; $\mathbf{c}$ ) if the Brazilian Patent Office judges that the patent should be granted, then it is passed to ANVISA where it undergoes a second assessment; d) ANVISA examines the application and the Brazilian Patent Office's decision, often applicationing additional material from the patent office and the applicants; e) ANVISA may deny or grant its prior consent to the patent, but even when it grants prior consent it may do so only after requiring that the applicant narrow some of the patent's claims; $f$ ) ANVISA's report is returned to the Brazilian Patent Office, which can formally grant the patent only if ANVISA has given its prior consent (SHADLEN, 2011).

Prior consent has, since then, caused tension between the institutions involved in the grant of patents and other interested parties. Ever since its adoption, several patent grants issued by the Brazilian Patent Office have been denied by ANVISA. In addition, among the granted patent, many had some of their rights granted by the Brazilian Patent Office restricted. Moreover, several granted patent applications had to provide better descriptions of the inventions so that the report was as complete as it could be, in accordance to the demands of the Patent Act in force (Art. 25).

The Brazilian Patent Office understands that they have exclusive competency to analyze the three patentability requirements, as well as two other social contract criteria established by the patent system - sufficiency of disclosure and best mode; and that, therefore, ANVISA should not, in their prior consent examination, evaluate whether those requirements had been fulfilled. According to the Brazilian Patent Office, ANVISA should focus on analyzing eventual risks to public health only.

ANVISA, on the other hand, has been holding on to the understanding that their analysis of possible risks to public health has to be done while observing the patentability criteria and the other necessary legal criteria for a legitimate patent. Patents that do not have novelty or non-obviousness (two of the patentability requirements), or that 
act against national public health by not having sufficiency of disclosure in its claims for the reproduction of product or process in situations of national emergency or government use, for instance, would put public health at risk and thus, according to ANVISA, those requirements should be part of their criteria when undertaking prior consent examinations.

By the end of the 2000's, the Brazilian Patent Office no longer recognized ANVISA's role in patent examination through administrative, legal and legislative channels by considering that ANVISA's role was to deal only with matters concerning health but not with patentability criteria.

In several moments, additional information about filed patents required by ANVISA were not supplied by the Brazilian Patent Office, hindering the continuity of the examination by the Agency. In the cases of denied prior consent, the Brazilian Patent Office adopted a position of not denying the patent application but freezing it instead with the goal of making time to wait for the end of ANVISA's power over this examination $^{202}$ (SHADLEN, 2011).

Many attorneys with foreign clients, the multinational pharmaceutical industry as well as the Brazilian Patent Office understand that ANVISA must not examine the three patentability requirements or the other two social contract criteria established by the patent system - sufficiency of disclosure and best mode. The World Health Organization (WTO), as well as other human rights advocates, on the other hand, are for a more extensive participation by ANVISA. The CIPR Report by the Government of the United Kingdom also understands that ANVISA “[...] may be in a better position to comment on, for example, the inventiveness of the claimed invention."203

According to Shadlen (2011), the national pharmaceutical industry initially approved prior consent, however, this support has weakened throughout the years. At present, its representatives seem to be torn over this issue, leaning towards not supporting ANVISA due to the development of growing training programs for the development of incremental innovation.

For Shadlen (2011), what is behind the conflict are substantive differences in the examination of patent applications. While the Brazilian Patent Office's examination guidelines could facilitate the patenting of incremental innovations, including new forms of known substances and new uses, ANVISA's approach would be more restrictive, only granting patents to proper innovations. To ANVISA, new forms of known substances

202 If the patent was denied by the Brazilian Patent Office, it could not be granted at a later date.

203 See United Kingdom, Commission on Intellectual Property Rights (CIPR), Integrating Intellectual Property Rights and Development Policy, London, 2002. 
lack inventive activity and new uses lack novelty. The agencies have irreconcilable differences regarding the merit of incremental innovation for patents.

The reaction of other government bodies to the dispute is not unanimous.

\section{DECISION OF THE BRAZILIAN INTER-MINISTERIAL GROUP ON INTELLECTUAL PROPERTY (GIPI)}

In December 2008, the Inter-ministerial Group on Intellectual Property (GIPI) declared a consensual position against granting patents for incremental pharmaceutical innovations. In that context, this declaration supported the presuppositions of ANVISA's examination. the Brazilian Patent Office, however, dismissed GIPI's resolution, declaring that they would not change their examination practices without an alteration on the Act itself (SHADLEN, 2011).

In short, there is a larger conflict behind the dispute between the promotion of incremental innovations through the patent system and the minimization of periods of market exclusivity, with direct impact in medical costs, technology diffusion and market competition.

\subsection{Prior consent: the legal debate}

The right to patent has a constitutional foundation. Upon existing novelty, nonobviousness and industrial application, as well as the observation of the other legal criteria, the subjective constitutional patent right is ascertained. Thus, there would be no space left for a discretionary manifestation to the Public Administration regarding patent grant. Those presuppositions are derived from the constitution and embodied in the Patent Act (Denis BARBOSA, 2009).

To Denis Barbosa (2009), prior consent is constitutional. The author cites Basso (2006), for whom, in the Brazilian Constitution, there is nothing appointing the Brazilian Patent Office as the only legitimate body for the examination of patent claims, which does not configure illegal activity in its shared function with ANVISA.

Carvalho (2002) clarifies that members of the WTO may bestow the responsibility of examining inventions to different agencies according to their fields of expertise. The Paris Convention, which was the first international agreement concerning patents, of which Brazil is signatory, indicates the need for an official body to communicate the patent grant to the public but not to examine it. 
Denis Barbosa (2009) mentions several legal decisions that confirm this position. As stated by one of them ${ }^{204}$ :

A correct interpretation of Article 229-C [of the Patent Act] leads us to the conclusion that ANVISA'sconsent for granting a patent in the pharmaceutical scope must correspond to the analysis of the patent requirements as the identification of whether or not a product or process is harmful to health was already part of ANVISA's Founding Act. Understanding otherwise is rendering the letter of the law void.

Denis Barbosa also remembers that, historically, a special regime has always been available for pharmaceutical patents, in consonance with the Constitution. Since 1883, the institutions that preceded ANVISA could be called upon to examine patents; therefore, the prudent two-fold examination of the object of pharmaceutical inventions is not, either now or in the past, a reflection of unconstitutionality.

Thus, according to the author, the legal standard that prevailed in the Brazilian system is now replicated through the two-fold examination of patent applications for pharmaceutical products and processes.

In short, Barbosa (2009) argues that the examination by ANVISA is provided by law and inevitable. With the creation of prior consent, "the examination prior to patent grant - without excluding pipeline patents -, it became mandatory for that autarchy to examine patent requirements."

Denis Barbosa reiterates that:

"all interested parties have the power of manifestation before a patent procedure; but ANVISA, in what concerns patent applications within its fields of expertise, has the legal duty to do so. In addition, the Brazilian Patent Office has the legal duty to heed all interested parties, ANVISA included, while deciding on such applications."

Faced with the absence of details in the legislation about the procedure to be adopted, or its effects, the institute of prior consent has been permeated by questions. The main one being whether ANVISA would have the attribution and competency to analyze the three patentability requirements, as well as other criteria from the social contract established by the patent system - sufficiency of disclosure and best mode. In this context, for each ANVISA denial, the Judicial Branch saw the appearance of demands questioning the role of the Sanitary Autarchy. 
In the administrative sphere, the Brazilian Patent Office initiated a formal investigation at the Office of the Attorney-General (Advocacia-Geral da União - AGU), that issued in 2009 the Opinion 210/PGF/AE/2009205, determining that both ANVISA and the Brazilian Patent Office should have roles in the processes of patent rights in the pharmaceutical field according to their attributions.

\section{THE PRIOR CONSENT CASE: OPINIONS BY THE OFFICE OF THE ATTORNEY-GENERAL}

The understanding of the Office of the Attorney-General is that it is not ANVISA's attribution to analyze the three patentability requirements, as that would be an attribution of the Brazilian Patent Office. ANVISA's role in the exercise of prior consent, according to the issued opinion, should be limited to the analysis of the harmful potential of the product towards human health.

At the time, ANVISA, the Minister of Health and the Minister of Science, Technology and Innovation ${ }^{206}$, along with civil society groups ${ }^{207}$, as well as other actors, required the review of Opinion no. 210/PGF/AE/2009.

AGU, however, confirmed their prior decision, by means of Opinion 337/PGF/ EA/2010208, published in January 2011. The new opinion did not accept the application for a review and went further in stating that ANVISA's prior consent should be limited to the mere presentation of inputs for the examination, which the Brazilian Patent Office could take into account or not.

The Opinion mentioned above has been highly criticized by some sectors, as it ignores the law. Article 229-C of the Patent Act determines that "granting patents for pharmaceutical products and processes depends on prior consent by ANVISA". "Depend" does not mean merely to consider, but that the patent application cannot be granted if there is no prior consent. Moreover, any interested party may put forth "inputs" to examination, in accordance to Article 31 of the Patent Act and, therefore, that must not have been what the legislator aimed for.

205 a) It is not ANVISA's competency to promote examinations (assessment/reassessment) of patentability technical criteria (novelty, non-obviousness and industrial application) when the action for prior consent is taking place (Article 229-C of Act No. 9279/1996, altered by Provisional Act No. 2006, December 12, 1999, later converted into Act No. 10.196/2001), as it is an assignment of the Brazilian Patent Office itself, as stated in the act itself (Article 2 of Act No. 5.648/1970);

b) ANVISA, for the purposes of Article 229-C, Act No.9.279/1996 must act in accordance with the institutional responsibilities (Article 6 of Act No. 9.782/1999): to prevent by health control the production and marketing of products and services that are potentially harmful to human health;

c) The role of ANVISA, with respect to prior consent, also involves processes relating to pipelines (Article 230 of Act No. 9.279/1996), according to Opinion No. AGU/MP-09/2006, dated July 2006 and Order No. 400/2008 by Federal Consultant General, dated October 28, 2008; "(Opinion No. 210/PGF/AE/2009, p. 13).

206 ESTADO DE SÃO PAULO. Ministérios da Saúde e de Ciência e Tecnologia intervêm por ANVISA no caso de patentes, 12 de agosto de 2010. Available at http://www.estadao.com.br/estadaodehoje/20100812/ not_imp593908,0.php.

207 Letter to the Federal Attorney General, Mr. Marcelo Siqueira, requiring that ANVISA maintains prior consent. Available at: http://www.petitiononline.com/gtpi2/petition.html.

208 AGU. Case no. 00407.005325/2007-71. Available at http://www.agu.gov.br/sistemas/site/Templatelmagem TextoThumb.aspx?idConteudo $=153676 \& i d$ site $=3$. 
The harmfulness of a pharmaceutical product is weighed by ANVISA when a sanitary record is required for its commercialization, when all necessary studies to back this analysis are produced. This examination of harmfulness to health happens at a later moment, after the patent grant. And it is already mandatory by law. Sanitary record has nothing to do with patent and, therefore, it makes no sense for the legislator to institute a new mechanism in the Patent Act for ANVISA to undertake the same analysis it would have otherwise undertaken at a later time, and with the same propriety.

In that context, it would be impossible for ANVISA experts to analyze the harmfulness of a product to human health with only the information contained in a patent application. That is because there are several typed of patent applications in the pharmaceutical sector, encompassing different phases of development of a medicine. For instance, protection can be applicationed for a compound with activity toward a certain disease without the realization of clinical tests and, even then, the invention may observe the three patentability requirements.

Moreover, it is possible to require protection for pharmaceutical molecules without a specific determined use, that is, in the patent application phase it is not yet possible to determine whether that molecule will really be used in the future for some medicines.

That is the understanding being put forth by ANVISA's examiners themselves while trying to apply legal decisions ${ }^{209}$ which, following the AGU orientations, determine that prior consent be limited to analyzing the risks for human health. In their own words ${ }^{210}$ :

the application for such verification in patent rights is new, and, due to the peculiarities that characterize an administrative process of patent application, it brings difficulties to the examiner that undertakes it, as, naturally, a patent application does not contain enough elements for the realization of an analysis of harmfulness to the human health.

And $^{211}$ :

Given that the characteristics of a patent application's text are regulated by administrative acts of the Brazilian Patent Office and the characteristics of the text of a patent application for registration of medicines are regulated by ANVISA, one can reach the conclusion that the analysis of prior consent

209 Court decision in the case file No. 2009.34.00.037368-5, 5th Federal Court of the Federal District Judiciary Section.

210 ANVISA, Parecer técnico de formulação de ciência a pedido de patente de produtos e processos farmacêuticos. Opinion no. 230/10/COOPI/GADIP/ANVISA. 10 December 2010. p. 1.

211 Idem. p. 1. 
based on weighing public health motivations, notably sanitary risk, renders all patent objects in the field of pharmaceutical products and processes carriers of potential immeasurable risk, as information considered fundamental for the analysis of a patent application differs from information necessary for the evaluation of sanitary risk.

In other opinion ${ }^{212}$ that reached the same conclusion:

The analysis of sanitary risk of a product (medicine) is a procedure that involves its own routine and depends on defined conditions and parameters by its constituents.

The analyzed patent application, therefore, does not hold all information necessary to weigh on the quality, safety or efficacy of the claimed object, reason by which it would be technically impossible for ANVISA to examine such requirements in the moment of the prior consent examination.

As a consequence of the technical impossibility of verifying the harmfulness of the product in question through documents contained in the patent application, ANVISA decided to deny prior consent, "due to the lack of definition of the claimed object as well as lack of information regarding safety and efficacy towards the intended use, it poses intrinsic risks of health damaging". ${ }^{213}$

Thus, in case the understanding that ANVISA must examine the risk of harmfulness for the human health in the exercise of prior consent upon pharmaceutical patent applications prevails, we can assume that all applications will be denied of consent, due to the implicit risk to health posed by a medicine and faced with a lack of necessary information to evaluate the actual risk posed by the product. Should ANVISA application that information during the examination of the patent application will be considered an insult to the WTO TRIPs Agreement as it would mean the creation of a fourth patentability requirement. This infringement could weigh heavily on the Brazilian government in case of the eventual establishment of a dispute settlement panel in that Organization.

We find it is still relevant to comment on the argument that it is not the institutional purpose of ANVISA to analyze the three patentability requirements themselves, as well as the other two social contract criteria established by the patent system - sufficiency of disclosure and best mode.

212 ANVISA, Parecer técnico de formulação de ciência a pedido de patente de produtos e processos farmacêuticos. Opinion no. 250/2010/COOPI/GADIP/ANVISA, of 19 November 2010, p. 6. Opinion prepared in compliance with the judicial decision in the case file No. 2009.34.00.037369-9.

213 Idem. p. 8. 
Law no. 9782/99 that created ANVISA provides its institutional purpose as such:

Art. $6^{\circ}$, Lei $\mathrm{n}^{\circ}$ 9.782/99. The Agency will have the institutional purpose of promoting the population's health by means of the sanitary control of production and commercialization of products and services under sanitary surveillance, including environments, processes, materials and related technologies, as well as the control of ports, airports and frontiers.

In other words, ANVISA's institutional purpose is to promote the protection of public health. It is important to understand protection of public health comprehensively. The right to access to medicines is contemplated in the right to health and it can be seen through different dimensions: (1) availability; (2) geographic accessibility; (3) acceptability; (4) quality of products and services; (5) affordability ${ }^{214}$.

By "affordability" we understand the relationship between the user's power of purchase of products and services and their price. Thus, protection to health is not limited to avoiding possible damages of a certain product to the health of a population, but also seeking the means to achieve affordability, such as the implementation of measures to avoid unjustifiable monopolies that will have an impact on prices.

The UN Special Rapporteur for the right to health ${ }^{215}$ highlights the negative effect of patent protection in the affordability dimension of the access to medicines:

Affordability of medicines correlates significantly with patents for pharmaceutical products. Patents confer legal rights and more importantly negative rights, on inventors over process or product inventions. Patentees can, therefore, prevent persons not authorized by them from making, using, offering for sale, selling or importing the patented invention. Patents create monopolies, limit competition and allow patentees to establish high prices. While product patents confer absolute monopolies, process patents lead to relative monopolies. In this regard, when patents are used to limit competition, they can have a significant impact on access to medicines.

Thus, by adopting an extensive concept of public health and recognizing the impacts of patents to health, it becomes evident that the examination of the three patentability requirements by ANVISA, as well as of the other two social contract criteria established by the patent system - sufficiency of disclosure and best mode; with the aim of avoiding the grant of inappropriate pharmaceutical patents is, indeed, part of the institutional

214 Luiza, V. L., 2003. Acesso a medicamentos essenciais no estado do Rio de Janeiro. Tese de doutorado. Rio de Janeiro: ENSP/FIOCRUZ; e OLIVEIRA, M.A. et al. Avaliação da assistência farmacêutica às pessoas vivendo com HIV/AIDS no Município do Rio de Janeiro. Cadernos de Saúde Pública; n. 18, v. 5, p. 1429-39, 2002.

215 Letter sent in 2009 to the then President of the Federal Supreme Court, Gilmar Mendes. Available at: http://www.abiaids.org.br/_img/media/Audiencia_STF.pdf. (translated from the original) 
attributions of this Agency. It is important to highlight that the Article 196 of the Brazilian Constitution supports this extensive concept of public health. ${ }^{216}$

\section{THE PATENT OFFICE'S NON-EXCLUSIVE POWER}

There is no law attributing the examination of patent applications and the observation of patentability requirements exclusively to the Brazilian Patent Office, or of the two other social contract criteria established by the patent system - sufficiency of disclosure and best mode. In the Constitution, there is nothing determining which organism is responsible for the examination and granting of patents in Brazil. There are no grounds, therefore, to raise the issue of exclusive power by the Patent Office.

The Brazilian Patent Office's leading attribution is the put into practice the norms regulating industrial property ${ }^{217}$, which does not mean that this is an attribution exclusive to the Autarchy. In fact, no law attributes to the Brazilian Patent Office the exclusive competency to examine and grant patent applications; not its founding act - Law no 5648/70 - nor the Patent Act.

The Patent Act ${ }^{218}$ only determines that patent applications follow the conditions established by the Brazilian Patent Office, which must undertake a preliminary examination about the observation of such conditions, but nowhere does the law provide that the Brazilian Patent Office must be responsible, least of all the sole responsible - for the technical examination and grant of such applications.

It is worth highlighting that in regard to industrial designs ${ }^{219}$, the Industrial Property Act expressly determined that the Brazilian Patent Office must issue an opinion of merit about the examination of the registration object, which does not occur in the chapter about patents.

216 Article 196. Health is a right of all and a duty of the State and shall be guaranteed by means of social and economic policies aimed at reducing the risk of illness and other hazards and the universal and equal access to actions and services for its promotion, protection and recovery.

217 Law No. 5.648/70, Article 2. the Brazilian Patent Office has as its main purpose to execute nationwide the rules that regulate industrial property, in view of its social, economic, legal and technical roles, as well as give its opinion on the convenience of signature, ratification and denunciation of conventions, treaties, covenants and agreements on industrial property.

218 Industrial Property Act, Article 19 - A patent application, in accordance with the conditions established by the Brazilian Patent Office, will contain: I-a application; II - a specification; III - claims; IV - drawings, if any; $\mathrm{V}$ - an abstract; and VI - proof of payment of the filing fee.

Industrial Property Act, Article 20 - Once presented, the application will be submitted to a formal preliminary examination and, if in due order, will be protocolled, the date of presentation being considered as the filing date.

Industrial Property Act Act, Article 21 - An application that does not formally meet the requirements of article 19, but which does contain data relating to the subject matter, the applicant and the inventor, may be delivered to the Brazilian Patent Office against a dated receipt which will establish the requirements to be met within a period of 30 (thirty) days, on pain of return or shelving of the documentation. Sole Paragraph Once the requirements have been met, filing will be considered to have been made on the date of the receipt.

219 Industrial Property Act, Article 111 - A registrant of an industrial design may, at any time during the term of registration, application examination as to novelty and originality of the object of the registration. Sole Paragraph - the Brazilian Patent Office will issue an opinion on merit that will serve as the basis for the ex officio institution of a post-grant opposition if it is concluded that at least one of the requirements provided for in articles 95 to 98 are absent. 
The WTO's TRIPs Agreement, in its Article 1.1220, establishes that countries may freely determine the appropriate way to implement the provisions of the Agreement in the scope of their own legal systems and practices. Nuno Pires de Carvalho explains ${ }^{221}$ :

A WTO member may also confer the authority to carry out the substantive examination of inventions to various agencies according to their expertise. The Paris Convention (Article 12) refers to a central office for the purposes of communication to the public of patents, not to examine them.

International rules, therefore, do not stipulate which organism must be in charge of the examination of patent applications nor even establish that only one organism must fulfill that role. Countries may, at their discretion, attribute the examination of patent rights to the organisms they deem more appropriate according to their national policies.

The Brazilian Constitution does not establish which is the organism responsible for granting patents, leaving that attribution for the Patent Act. There is no law establishing that a technical exam in patent applications, - and, therefore the analysis of the three patentability requirements, along with the other two social contract criteria established by the patent system: sufficiency of description and best mode - are the Brazilian Patent Office's attribution and much less, the exclusive attribution of this organism.

The Patent Act, in determining that the grant of pharmaceutical patents depended on prior consent by ANVISA, attributed to them the power/duty to analyze all requirements fixed by law for granting a patent - including the patentability requirements and other criteria established by law.

220 TRIPs Agreement. Article 1. Nature and Scope of Obligations. 1. Members shall give effect to the provisions of this Agreement. Members may, but shall not be obliged to, implement in their law more extensive protection than is required by this Agreement, provided that such protection does not contravene the provisions of this Agreement. Members shall be free to determine the appropriate method of implementing the provisions of this Agreement within their own legal system and practice.

221 CARVALHO, Nunes Pires. The TRIPs regime of patents rights. Kluwer Law International: The Hague, 2002. p. 161. 


\subsubsection{The public class action, and the complaint to the UN}

A public class action was filed against the AGU Opinion (46656-49.2011.4.01.3400) by the Federal Prosecutor Office, with the following order of merit: i) the declaration of invalidation of Opinion 210/2009; ii) the recognition of the legal attribution conferred by Article 229-C of the Patent Act to ANVISA, for the analysis of patentability requirements within the patent grant procedure for pharmaceutical products and processes in course at the Brazilian Patent Office; and iii) the declaration of the automatic application of the provision of the mentioned Article 229-C, rejecting any understanding to the contrary.

There was also the injunction application to lift the AGU Opinion, which was denied by a ruling of the $7^{\text {th }}$ Federal Court. Against this decision, a Bill of Review was filed, pending decision by the $6^{\text {th }}$ Chamber of the Federal Court of Appeals for the Federal District. The public class action remains without a decision on the merits.

Organizations of the civil society advocating for human rights filed a complaint to the UN Special Rapporteur towards the human right to health against the AGU's interpretation of ANVISA's role in the exercise of prior consent, arguing that it consisted of a regress in the protection to the right to health and was contrary to the obligation contracted with the UN of adopting all available measures for the actualization of the right to health in Brazil 222 . The complaint follows the regular procedures within the United Nations' framework.

\subsubsection{Inter-ministerial working group}

In the face of the mentioned discussion, through the Inter-ministerial Ordinance no. 1.956, of 16 August 2011, an Inter-ministerial Working Group (Grupo de Trabalho Interministerial - GTI) was created to harmonize the theme, with the participation of the Ministry of Health (MS), the Ministry of Development, Industry and Foreign Trade (MDIC), AGU, ANVISA and the Brazilian Patent Office. The initial results of this effort are embodied by the Inter-ministerial Ordinance no. 1065, of 24 May 2012, and in the final report produced by the GTI.

The Ministry of Science, Technology and Innovation, the Ministry of Foreign Affairs, and the Ministry of Justice did not take part in the Group. If they did, the result would most probably be different, more balanced, as it would involve more field experts and agents of the Brazilian State.

222 The full text of the complaint made by Brazilian society organizations against the interpretation of Article 229-C of the Patent Act, conferred by the National Attorney General (AGU), sent to the UN Special Rapporteur for the human right to health is available at: http://www.patentes.org.br/media/file/Urgent\%20 appeal\%20against\%20Brazil\%20-\%20by\%20GTPI\%20\%28with\%20annexes\%29.pdf. 
A new work-flow in the processing of applications was proposed:

I - the Brazilian Patent Office will undertake the formal initial examination of the documents filed by the patent applicant;

II - after the approval of the application upon formal examination, the Brazilian Patent Office will identify the type of product and process and send the applications for pharmaceutical products and processes to ANVISA;

III - ANVISA will proceed with the examination of applications sent by the Brazilian Patent Office and will publish its opinion, with or without its consent, in the Official Gazette;

IV - after the publication of their opinion, ANVISA will give back the applications to the Brazilian Patent Office;

V - (a) if ANVISA consents to an application, the Brazilian Patent Office will proceed to its technical examination and will publish the notice of patent grant or archiving of the application, according to their evaluation, in the Industrial Property Review (Revista de Propriedade Industrial); (b) if ANVISA does not consent to an application, the Brazilian Patent Office will archive the application and publish a notice about the archiving in the Industrial Property Review.

The GTI report highlights that the participation of ANVISA must necessarily take place by means of a prior consent prior to the Brazilian Patent Office's examination, considering ANVISA's technical-scientific capacity and based in pertinent and relevant criteria for its prior consent, with the objective of evaluating the impact of pharmaceutical products or processes in the market taking account of public health principles. Thus, the new work-flow improves the efficiency of the examination of patent applications by avoiding redundancy in examination in case of applications without ANVISA's consent.

This work-flow inversion, however (it is befitting to remember that ANVISA previously only examined applications that the Brazilian Patent Office understood as eligible for grant), will increase the number of applications sent to ANVISA, which must receive the necessary human and technological resources needed to properly meet the demand. Part of the legal uncertainty today may continue to exist in case some aspects are not clearly defined and circumscribed, such as:

1. What will be the deadlines for the analysis of each step, and the applicable appeals?

2. When and how will the existing and pending problems on examined or pending applications be resolved while this measure does not come into force? 
3. How will the interconnection of procedures between ANVISA and the Brazilian Patent Office take place?

\subsubsection{ANVISA's Public Consultation no. 66/2012}

In 24 October 2012, ANVISA initiated the Public Consultation no. 66/2012, with the duration of 60 days, to collect society's contributions regarding applications for pharmaceutical patents and the relationship between ANVISA and the Brazilian Patent Office over the matter of prior consent. The public consultation proposed the alteration of RDC 45/2008, that provides about the administrative procedure regarding ANVISA's prior consent for the grant of patents for pharmaceutical products and processes.

After ANVISA Resolution RDC 45/2008 has undergone public consultation, it was amended by Resolution RDC 21/2013, now reading as follows:

Article 1: Articles 2, 4, 5, 7 and 8 of Resolution RDC no. 45 of June 23, 2008 shall henceforth read as follows:

"Article 2: For the purposes of this Resolution the following definitions are adopted:

I - prior consent: deliberative act of ANVISA issued in the fulfillment of art. C-229 of Law no. 9279 of 1996, in which the agency examines the object of the patent application in light of public health;

(..)

Article 3: The Brazilian Patent Office shall forward the patent applications to ANVISA so that the latter may analyze the applications, and based on a reasoned decision, ANVISA will approve or deny approval of the patent application.

Article 4: Upon receipt of patent applications from the Brazilian Patent Office, ANVISA shall examine such applications in light of public health, upon decision embodied by a technical opinion issued by the competent organizational unit in the Agency's framework.

$\S 1$ A patent application shall be considered as contrary to public health, according to further regulation, where:

I - the product or pharmaceutical process in the patent application present a health risk, or

II - the patent application for pharmaceutical product or pharmaceutical process is of interest to an access to medicines policy or to a pharmaceutical care program under the National Health System - SUS, and provided that it does not meet the patentability requirements and the other criteria established by Act no. 9.279, of 1996 [the Patent Act].

$\$ 2$ There shall be risk to health when the pharmaceutical product, or the pharmaceutical process, result in substance whose use has been banned in the country.

$\$ 3$ The patent application for pharmaceutical product or process is considered to be of interest to drug policy or pharmaceutical services under SUS when it is part of, or result in, a substance that is part of the lists resulting from Ordinances of the 
Ministry of Health on strategic products to SUS, and the updated lists, or result in a substance belonging to a treatment listed on the above mentioned Ordinance.

$\$ 4$ The parameters for analysis of health risk and interest policies of medicines or pharmaceutical services under SUS will be detailed in the act itself.

$(\ldots)$

Article 6: REVOKED

Article 7: Any decision on the conclusion of the examination for prior consent will be published in the Official Gazette.

$\$ 1$ The decision to deny approval of the application may be appealed to the Board of ANVISA within sixty days (...).

$\$ 2$ After ANVISA's final decision, the application shall be returned to the Patent Office for the completion of the administrative procedure.

Article 8: Petitions and documents of this Resolution shall be received according to the protocol specific regulation on the ANVISA

Several attorneys of large multinational pharmaceutical companies, associations of attorneys and agents of intellectual property, the American Chamber of Commerce, the Intellectual Property Association of Japan, Interfarma (formed by multinational pharmaceutical industries), as well as national NGOs, government sectors and the national industry have manifested about the public consultation and the new proposed text.

Resolution RDC 45/2008 was amended by Resolution RDC 21/2013, which updates the processing of patent applications and establishes that ANVISA shall consider public health interest in two situations, and therefore reject patent applications that: (a) present a health risk, and (b) are of interest to the welfare policies of the National Health System (SUS) and do not meet the patentability requirements and other criteria set by the Patent Act.

In this sense, the products of interest to SUS will be those contained in the list of strategic goods from the Ministry of Health or the substances intended for therapeutic purposes of this list. ANVISA shall also examine applications where it deals with products banned in the country. 


\subsection{Restriction to patent applications under the pipeline mechanism}

Another proposal ${ }^{223}$ has been discussed about the participation of ANVISA in the process of grant of pharmaceutical patents: that prior consent could only prove necessary for patent applications filed under the mechanism known as pipeline. ${ }^{224}$

Pipeline patents are provided in the Articles 230 and 231 of the Patent Act. By means of this mechanism, the filing of patent applications in technological fields of expertise for which Brazil did not previously issue patents (mainly medicines and food) until 2006 (date of publication of the Patent Act) was made possible. The filing of a patent application through the pipeline mechanism was accepted only for the duration of one year, between May 19966 and May 1997. Pipeline patents would "revalidate" nationally the patents of medicines, foods and chemical-pharmaceutical products and processes issued abroad without undergoing technical examination of patentability requirements by the Brazilian Patent Office. A total 1,182 patent applications were filed through the pipeline mechanism.

Pipeline patents could only be filed for a certain period. Therefore, by linking ANVISA's prior consent to those types of applications only, prior consent would also only be valid for a certain period, becoming extinct after the examination of patents filed through the pipeline mechanism.

Those who advocate in favor of this limitation of prior consent employ as argument the fact that the Article 229-C, which instituted the mechanism, is located under the title "transitory and final provisions" of the Patent Act. This was the argument used by the Brazilian Patent Office when filing a review by the AGU regarding the time span of the prior consent (Opinion no. 337/PGF/EA/2010, p.2). In 2009, AGU issued an opinion that, among other things, stated that prior consent should apply to all pharmaceutical patent applications, not only pipeline, a position that was confirmed by AGU in 2010, after the application for reconsideration of their opinion.

The simple legislative topography cannot be used as argument to restrict the application of ANVISA's prior consent to patent applications filed under the pipeline mechanism. Despite the fact that the article which included prior consent was located under the transitory and final provisions title, that, in itself, does not imply that it is also a transitional provision. Other articles included in the same chapter also have permanent

223 Bill No. 3.709/08, by Congressman Rafael Guerra (PSDB/MG), and the Bill No. 7.965/10, by Congressman Moreira Mendes (PPS/RO) deal with the subject and are being discussed jointly at the Chamber of Deputies.

224 For more information on pipeline, see Chapter 6 of this Report and the Direct Action of Unconstitutionality - ADI 4234 (or Ação Direta de Inconstitucionalidade), proposed by the Federal Attorney General from represented civil society organizations challenging the constitutionality of the mechanism. The written application of the action, opinions of authorities and documents sent by different civil society actors on the topic can be found on the website of the Federal Supreme Court: www.stf.jus.br 
character. Article 240, for instance, which establishes the purpose of the Brazilian Patent Office, and Article 24l, authorizing the creation of special intellectual property courts, are not mere transitional provisions, despite being included under this title.

In order to avoid biased interpretation, we propose a legislative alteration aimed at making evident that ANVISA's prior consent is applicable to all types of patent applications in the pharmaceutical field and not just those filed under the pipeline mechanism.

\subsection{ANVISA's prior consent and its relevance to public health}

In this section we deal with ANVISA's participation on applications for the grant of pharmaceutical patents in order to make evident the importance of this participation for the protection of public health.

An important study conducted by ANVISA makes a qualitative analysis of the decisions issued in the exercise of prior consent for the period between 2001 and $2009^{225}$ and shows how the participation of the Agency in patent grant procedures has been proving relevant not only to avoid the grant of inappropriate patents but also to increase the quality of granted patents. It is important to remember that ANVISA only analyzed patent applications after examination by the Brazilian Patent Office and only when the latter considered the application ready for granting - as the Inter-ministerial Working Group had not yet gathered to deliberate about the procedures.

Between 2001 and 2009 (until October), ANVISA analyzed 1,346 patent applications. Out of those applications: i) 988 were granted consent; ii) 119 were denied consent; iii) 90 were barred by the Brazilian Patent Office after ANVISA's examination and iv) 149 were in other situations as of the conclusion of the study (such as waiting for ANVISA's examination or for the fulfillment of requirements by the applicant). The main reasons for denial of consent by ANVISA are shown in the following table.

225 Coordenação de Propriedade Intelectual - COOPI/GGMED/ANVISA. Technical opinion concerning Bill No. 3.709/2008. November 25, 2009. Available at:: http://www2.camara.gov.br/atividade-legislativa/ comissoes/comissoes-permanentes/cdeic/audiencias/audiencia-publica-24-11-2009/Parecer\%20 Tecnico\%20relativo\%20ao\%20PL3709-2008.pdf/at_download/file. 
Table 7 Reasons for denial of prior consent by ANVISA (2001 a 2009)

\begin{tabular}{|lrr|}
\hline Main reason for denial of prior consent & n. & $\%$ \\
\hline Absence of novelty (total or partial) & 57 & $47.9 \%$ \\
\hline Absence of inventive activity (non-obviousness) & 27 & $22.7 \%$ \\
\hline Insufficiency of disclosure & 19 & $16 \%$ \\
\hline Natural product & 7 & $5.9 \%$ \\
\hline Object vagueness & 6 & $5 \%$ \\
\hline Alterations in the application after the deadline & 2 & $1.7 \%$ \\
\hline Filing after the deadline & 1 & $0.8 \%$ \\
\hline Total & 119 & $100 \%$
\end{tabular}

According to the ANVISA study, concerning those 119 patent applications, the Brazilian Patent Office only denied patent for 6 cases and other 7 were archived. The other 106 applications were put on the backburner and did not go further whichever way within the framework of the Brazilian Patent Office. It is important to clarify that ANVISA cannot directly deny patent. ANVISA, after their final decision about the consent, sends the patent application back to the Brazilian Patent Office, which is in charge of the final decision about the patent application and its subsequent publication.

Thus, in the cases for which ANVISA has denied consent, the Brazilian Patent Office should publish their refusal - which has not been the case. Legally, from this refusal there are legal and administrative appeals available for the patent applicant. However, what has been taking place is a situation of uncertainty that brings consequences for the society as a whole, since the Brazilian Patent Office is keeping those applications open; in other words, it does not deny or grant the patent application.

\section{THE BRAZILIAN PATENT OFFICE INERTIA CAUSES LEGAL UNCERTAINTY AND CREATES DE FACTO MONOPOLY}

In practice, the inertia on the Brazilian Patent Office's part means that the object of patent application does not enter the public domain - which would happened when the refusal was published - affecting potential competition for the applicant intending to explore the technology, as there is legal uncertainty about the case in point. One may say that the patent applicant enjoys a de facto monopoly, given that legal uncertainty may drive away the competition from entering the market, which would not be the case if the patent had already been officially refused. 
Besides, it is important to highlight that, out of the 988 applications that received prior consent by ANVISA, around $40 \%$ were only approved after they met some requirements posed by the Agency. According to the study, the better part of those requirements deflated the scope of the claims, faced with lack of novelty, inventive activity (non-obviousness) or encompassed non-patentable material. In other cases, the requirements were meant to clarify what the object of protection was, improving the quality of granted patents.

\section{BENEFITS OF ANVISA'S PRIOR CONSENT - INCLUDING ANALYSIS OF PATENTABILITY REQUIREMENTS}

In other cases, the participation of ANVISA in the process led the Brazilian Patent Office to change its view on the grant of a patent application that would have been issued if not for ANVISA. That happened in 90 cases. One of the emblematic cases that shows how the collaboration of ANVISA and the Brazilian Patent Office in the examination of applications of pharmaceutical patents can protect public health is the one concerning docetaxel, a drug used mainly in cancer treatments.

the Brazilian Patent Office had issued their preliminary decision for granting the patent application filed by Aventis Pharma S/A226, but ANVISA denied it prior consent based on lack of inventive activity. the Brazilian Patent Office, after ANVISA's decision, altered their prior examination and denied the patent. The grant of this patent could have been of great detriment to public programs of distribution of medicines and for consumers at large, since the patent could be used to prevent competition in the supply of this product.

In conclusion, the participation of ANVISA in the analysis of pharmaceutical patent applications not only prevented the grant of several invalid patents, but also corrected dozens of imprecisions in applications that, in the Brazilian Patent Office's view, appeared ready to be granted, reducing or clarifying the reach of the object protected by patent and therefore, increasing the quality in the examination and grant of patents, affording more legitimacy to the patent system itself and yielding greater legal certainty.

It is not for any other reason that the collaboration of health-related regulatory agencies and patent offices in the analyses of pharmaceutical patent applications was appointed as a measure to improve patent examinations under the perspective of public health, as highlighted by publication by Professor Carlos Correa, with the seal of the World Health Organization (WHO) as well as the United Nations Conference on Trade and Development. $^{227}$

226 Patent application no. P19508789-3.

227 CORREA, Carlos (professor). Guidelines for the examination of pharmaceutical patents: Developing a public health perspective, WHO-ICTSD-UNCTAD. University of Buenos Aires: January 2007, p. 25. 
The WHO also highlighted the participation of the health sector in examination processes in the pharmaceutical area as beneficial to public health for their efforts to avoid granting inappropriate patents. ${ }^{228}$

\subsection{Legislative proposal229}

Having in mind the above arguments, we propose amendments to the two following Laws:

Law no. 9782/99:

Article 7. [The Sanitary Agency shall implement and enforce the provisions set forth under sections II through VII of Art. 2 of this Law, and the Agency shall:]

XXVIII - participate in the process of examination of patent applications for pharmaceutical products and processes, including the analysis of the patentability requirements and the other criterion set forth under the specific legislation.

Patent Act:

Art.229-C. The granting of patents for pharmaceutical products and processes shall depend on the prior consent from the National Sanitary Agency - ANVISA, that shall examine the object subject to the patent application in light of public health.

$\$ 1$ A patent application shall be considered as contrary to public health, according to further regulation, where:

I - the product or pharmaceutical process in the patent application present a health risk, or

II - the patent application for pharmaceutical product or pharmaceutical process is of interest to an access to medicines policy or to a pharmaceutical care program under the National Health System - SUS, and provided that it does not meet the patentability requirements and the other criteria established by this law.

$\S 2$ Following the prior consent examination and after the decision is published, ANVISA shall return the application to the Patent Office, that shall examine the approved application, and definitely archive the application that has not been approved.

228 Relatório final da Comissão sobre direitos da propriedade intelectual, inovação e saúde pública. $\mathrm{CIPIH} / 2006 / 1$, p. 134.

229 Bill 3943/2012, attached to PL 3709/2008, is being discussed at the Chamber of Deputies. Both deal with the same subject. 


\subsection{Recommendations}

\section{a) To Congress:}

Approve Bill H.R. 5402/2013 in order to promote legal certainty regarding the Sanitary Agency's attributions in giving prior consent, to eliminate the possibility of diverging interpretations regarding the Agency's attributions of examining the three patentability requirements, as well as the other two criteria established by the patent law - sufficiency of disclosure (enablement) and best mode (see Art. 3 of Bill 5402/2013, attached, that amends Art. 229C of the Patent Act, and as well as Art. 7 of the 9782/99 Act on the National Sanitary System).

b) To the Executive Branch:

b.1) Immediately implement the Inter-ministerial Intellectual Property Group's (GIPI) resolution, and

b.2) To the Inter-ministerial Working Group (GTI) created by the InterministerialOrdinanceno. 1956/2011: expressly includethe due observance of the three patentability requirements in the recommendations made by GTI, as well as the two other criteria established by the patent law sufficiency of disclosure (enablement) and best mode.

b.2) to the Brazilian Patent Office (INPI):

b.2.1) follow the procedures recommended by the Inter-ministerial Working Group (GTI), in order to make the process clearer and afford it greater legal certainty, and

b.2.2) publish the patent applications that are presently pending and that have been examined by the Sanitary Agency for prior consent.

\section{b.3) to the Sanitary Agency - ANVISA:}

Keep duly observing, in the procedures of prior consent, the three patentability requirements, as well as the other two criteria established by the patent law sufficiency of disclosure (enablement) and best mode, as established by ANVISA's Resolution RDC 21/2013. 


\section{UNDISCLOSED TEST DATA PROTECTION}

Another theme that has been the object of debate is the protection of non-publicized information, submitted for the approval of the commercialization of products, in the pharmaceutical field. World sanitary authorities, much like in Brazil, usually demand as condition for the authorization of commercialization registration of pharmaceutical products, the presentation of data regarding the quality, safety and efficacy (test data: pre-clinical and clinical study phases I, II e III) of medicines, as well as information about the composition and characteristics of the product.

These data are fundamental for a precise examination with a view to approving the commercialization of any medicine, including generic drugs that also must prove the equivalence of active principles and medicine efficacy, to attest that the generic is actually equivalent to the reference product. The reference pharmaceutical industry, however, has been making efforts to protect these test data with exclusivity, to avoid their use as comparative bases for the approval of third-party products - such as generics, for instance.

The TRIPs Agreement demands only that those test data be protected against unfair commercial use (Article 39.3) - but there is no demand, however, for exclusivity rights. Nevertheless, some countries with high capacity for technological production, such as the United States, began granting exclusivity rights to test data and subsequent commercialization exclusivity during the same period, and they have been pressuring other countries to do the same.

However, the demand in the cited Article is established a limited fashion, leaving countries with flexibility and autonomy in its implementation. Moreover, in the analysis the of the content and extension of the provisions of Art. 39.3 of the TRIPs Agreement, one must present the provisions of the Doha Declaration on the TRIPs Agreement and Public Health, of 14 November 2001:

We recognize that intellectual property protection is important for the development of new medicines. We also recognize the concerns about its effects on prices.

We agree that the TRIPS Agreement does not and should not prevent members from taking measures to protect public health. Accordingly, while reiterating our commitment to the TRIPS Agreement, we affirm that the Agreement can and should be interpreted and implemented in a manner supportive of WTO members' right to protect public health and, in particular, to promote access to medicines for all. ${ }^{230}$

230 The full declaration is available at http://www.wto.org/english/thewto_e/minist_e/min01_e/mindecl_ trips_e.htm. 


\section{DATA EXCLUSIVITY HINDERS THE ENTRY OF GENERIC MEDICINES IN THE MARKET}

The exclusivity rights over test data prevent their use as a comparative basis for the equivalence factor in the registration of third-party products and pose an obstacle to the authorization for the commercialization of generic medicines for the duration of their term. Exclusivity of test data is, therefore, a measure that goes beyond international agreements (it is, therefore, TRIPs-plus) and hampers the entry of generic medicines in the market, besides discouraging national production, preventing the access by the Brazilian population to low-cost medicines, and should not be adopted by the Brazilian legislation as it is contrary to public interest and to the patent clause of the Constitution concerning the social, economic and technological development of the country.

In Brazil, Act 10.603/2002 regulates the protection of test data, providing over the protection of non-publicized information submitted for the approval of the commercialization of products and preventing the utilization of information for the registration of third-party products for a certain period of time.

This act, however, is limited to pharmaceutical products for veterinary use, fertilizers, agrochemicals, their components and related products (Article 1), excluding pharmaceutical products for human use. The Patent Act, in its turn, sees the employment by third parties of non-disclosed test data presented to government bodies as condition for approval of the commercialization of products (Article 195, XIV) as a crime of unfair competition.

This Article of the Patent Act has recently come to be interpreted by some people and some instances of the Judicial Branch as a deterrent for the use of test data even by the Sanitary Agency itself for the authorization of commercialization of third-party products. In practice, this interpretation bestows exclusivity upon these data and, thus unduly amplifies what the Patent Act stipulates. This interpretation, which, in some cases, is adopted by the Judicial Branch, puts the policy of access to health and medicines in Brazil at risk and, for that, it should be reviewed.

The present proposal for legislative alteration, thus, aims at preventing an interpretation of the Brazilian legislation according to which the use of test data by the sanitary surveillance authority configures a crime of unfair competition. Strictly speaking, there is no need for alterations in the legislation on the subject.

However, given the growing number of lawsuits filed by pharmaceutical companies and legal decisions preventing the granting of generic medicine registrations based in this interpretation, as well as the serious risk it represents for the country's health public 
policies, we believe that the proposed alteration can afford greater security for the use of necessary test data for the market approval of generic medicines.

As previously explained, the granting of rights allowing the commercialization of a product in a situation of temporary legal monopoly - as is the case of patents and also test data exclusivity - makes a negative impact on the access to the protected product by limiting purchase options to one supplier and allowing the practice of elevated prices.

In case of pharmaceutical products, for instance, the granting of those rights encumbers the effective implementation of health public policies, besides restricting the access to proper treatment by a large portion of the population. In this context, generic medicines have fundamental importance, since they are quality products commercialized at much more accessible prices.

In case of pharmaceutical products, for instance, the granting of those rights encumbers the effective implementation of health public policies, besides restricting the access to proper treatment by a large portion of the population. In this context, generic medicines have fundamental importance, since they are quality products commercialized at much more accessible prices.

In that sense, measures that hamper the access to generic medicines and do not derive from obligations contracted internationally - as is the case of data exclusivity - should not be adopted in Brazil.

Recently, the United Nations Special Rapporteur, Anand Grover (UN, 2009) approached the theme of implementation of the TRIPs Agreement and, after reaching the conclusion that the international system of intellectual property was not achieving its goals and was hampering the access to medicines, he recommended that developing and least developed countries review their national legislations to encourage the full employment of the flexibilities of the Agreement as well as the exclusion of TRIPs plus measures, which are more restrictive and protective than those demanded by the WTO and end up worsening the problems mentioned. The already cited Resolution WHA 61.21 by the World Health Organization deals with this issue.

Data exclusivity, as we will explain in more detail below, is a TRIPs plus measure and, as such, should not be included in the Brazilian legislation, having in mind the social interest for access to protected technology as soon as possible, especially in the case of technologies that have an impact in the fulfillment of human rights, as is the case of medicines.

Moreover, the United Nations Development Program (UNDP, 2010, p. 25) recommended that developing countries do not provide exclusivity in their national legislations. 


\subsection{Registration of generic medicines in Brazil, and the impact of data exclusivity}

In Brazil, the authorization for the commercialization of a pharmaceutical product is granted through a sanitary registration, more precisely, the registration or market approval of a medicine, as set forth by Decree no. 79.094/77 (as amended by Decree no. 3.961/01), that regulates Law no. 6.360/76, as follows:

Art. 3 Decree no. 79.094/77. Effective in this Regulation, the following definitions are adopted:

XXI - Medicine Registry - Instrument through which the Ministry of Health, in the use of its specific attribution, determines the prior registration in the organism or competent body, upon examination of compliance of legal-administrative and technical-scientific character related to efficacy, safety and quality of those products, for their introduction in the market and their commercialization or consumption.

It consists, therefore, of an authorization from a competent sanitary autarchy, presently ANVISA (National Agency of Sanitary Surveillance), without which the medicine could not be commercialized, aimed at facilitating the follow-up, monitoring and quality, safety and efficacy control in the pharmaceutical field, regarding aspects of toxicity and harmfulness to public health.

Before the manufacturer files for the market approval, the product must undergo a series of studies with the aim of demonstrating its activity in the human body. Usually, during the development phase of a medicine that will be used for the first time (and could be called innovative, original or pioneering), the analyses to determine the product's activity are only conducted by the manufacturer after a series of laboratory studies (in vitro) and animal tests (in vivo). Those are called pre-clinical studies, as they do not involve people. During the clinical studies phase, the activity of the pharmaceutical form in question is then determined in the human organism itself (in vivo).

Firstly, the tests are conducted with a small group of healthy individuals. Afterwards, they are repeated with a small group of patients with the malady the product is intended to treat. Only then, for purposes of obtaining the market approval, clinical tests with a larger number of patients under controlled conditions, that is, with standardized and documented procedures and permanent medical attention, can be conducted.

During clinical studies, it is fundamental to follow the ethical aspects listed in the norms of ethics of research in human beings, chiefly to inform each patient about the adopted procedures and the possible consequences of participating in the study (MENDOZA RUIZ, 2008, p.25). 
In Brazil, the products known as generic medicines are those that present pharmaceutical equivalence and bioequivalence with innovative products, as provided by Act 6.360/76, altered by Act 9.787/99.

\section{BIOEQUIVALENCE TEST}

Companies interested in commercializing a generic medicine must present the competent authority with information demonstrating that their product is equivalent to the innovative product, without the need to prove that the product is safe and effective as required for the registration of the innovative product.

The reason is simple: it is a known and previously examined medicine, which indicates that it has been through all the mandatory steps towards registration physical and chemical as well as non-clinical and clinical studies. This eliminates the need to conduct those studies all over again, as it is not reasonable to duplicate tests that will generate information already available.

It is worth highlighting that much of the information presented by manufacturers of generics are the product of comparability tests, which invalidates the thesis that those manufacturers do not incur in efforts or expenses towards the market insertion of their products.

A series of documents must be presented by the manufacturer of generic medicines, among which: the production report, the report of quality control of raw materials, stability studies, data about primary packaging and dosage accessories, the report of pharmaceutical equivalence and the report of biopharmaceutical tests. ${ }^{231}$

In short, all those examples show that the manufacturer of generic medicines is only obligated to prove the quality of their products, besides chemical equivalence to the reference medicine. There is no need for applicants of market approval for generic medicines to produce all test results required for the registration of the reference medicine, especially regarding safety and proven efficacy upon human testing.

231 In accordance with Resolução RDC n 16, March 2, 2007, available at: http://www.crfsp.org.br/joomla/ index.php?option =com_content $\&$ view $=$ article $\&$ id $=614 \% 3$ Aresolucao-rdc-no-16-de-02-de-marco-de2007 \& catid $=113 \% 3$ Alegislacao\&Itemid $=75$. 


\section{THE REPETITION OF CLINICAL TESTS IS CONTRARY TO THE ETHICAL PRINCIPLES OF THE WORLD MEDICAL ASSOCIATION}

If the generic medicine underwent tests indicating that it is equivalent to the reference medicine, then it makes no sense to demand that other animal and human tests be conducted, as the medicine being registered in actually the same.

In case the regulating agency is forbidden to base their examinations on those test results, the generic manufacturer will have to either a) conduct all tests demanded for the reference medicine all over again, in spite of the results being known, as the very same tests have already been conducted for the approval of the innovative product, or rather b) wait until the period for which data exclusivity was defined comes to term.

The unnecessary repetition of clinical tests is not only unreasonable but also absolutely contrary to the ethical principles of research on human beings adopted by the World Medical Association (Declaration of Helsinki). ${ }^{232}$

In addition to that, the demand for repetition of clinical and non-clinical tests would represent an additional cost to the manufacturer of generic medicines, consequently increasing the price of commercialization of the product or decreasing incentives to manufacturers of generics to file for product registration.

Without this registration, the product cannot be commercialized in the country, which can hamper the access to generic medicine by part of the population.

As an example of the importance of the use of clinical test data from reference medicine by manufacturers of generic medicines to the promotion of the access to medicines, we highlight a case that took place in the U.S.. In 1984, the approval of the Drug Price Competition and Patent Term Restoration Act; also known as Hatch-Waxman Act), made possible the use of the patented invention on required tests for market approval (experimental use).

In addition, there was the exemption of safety and efficacy tests for the generic medicine, enabling the regulating agency to use the data provided by the first product applicant as a parameter.

Only data proving that the generic medicine had the same technical characteristics as the innovative product should be presented (the same active principle, the same administration method, dosage and bioequivalence) (CHAVES, 2006). There was a 
subsequent increase in the number of generic medicines in the country, favoring the access to medicines.

As we said before, for their registration, generics undergo strict quality control to ensure similar results to the reference medicine. Every laboratory that intends to produce a generic medicine must be submitted to inspection of good practices of manufacturing, which examines, for instance, structural and technical conditions of the industry. To ensure generic quality, ANVISA examines the results of the bioequivalence tests. The presentation of pre-clinical and clinical tests results is dismissed upon proven bioequivalence or, if not applicable, therapeutic equivalence by means of appropriate clinical pharmacology studies.

\section{ONLY THE SANITARY AGENCY USES TEST DATA - NOT THE COMPETITORS}

To show that their product is equivalent to the reference medicine, the manufacturer of generic medicine needs not, at any given time, have access to or use test data for safety and efficacy presented by the manufacturer of the reference medicine. Those data are used only as reference by the Sanitary Agency.

The use of those data, evidently, does not constitute an unfair competition offense such as typified in Article 195, XIV of the Patent Act. And the interpretation that aims at preventing ANVISA from granting market approval for generic medicine under that argument puts access to medicines at risk, as well as public policies all over the country.

\subsection{Undisclosed test data vs data exclusivity}

The Article 39 of the TRIPs Agreement covers the protection of confidential information and, in its item 3, approaches the specific issue of test data for the approval of the commercialization registration of pharmaceutical products. For consideration:

TRIPs Agreement, Article 39.3. Members, when requiring, as a condition of approving the marketing of pharmaceutical or of agricultural chemical products which utilize new chemical entities, the submission of undisclosed test or other data, the origination of which involves a considerable effort, shall protect such data against unfair commercial use. In addition, Members shall protect such data against disclosure, except where necessary to protect the public, or unless steps are taken to ensure that the data are protected against unfair commercial use. 
The TRIPs Agreement demands, thus, that countries adopt two measures regarding the protection of data submitted for obtaining market approval of medicines: i) protection against unfair commercial use and ii) protection against disclosure of data except when necessary for public protection, or when other measures have been adopted to ensure that the data are protected against unfair commercial use. The creation of a data exclusivity regime, therefore, is not mandatory.

TRIPs does not define "unfair commercial use", falling upon each country to adopt their own definitions. Thus, the adoption of a data exclusivity regime in Brazil is not mandatory; only the protection of data against unfair commercial use.

\section{TRIPS' NEGOTIATION HISTORY SHOWS THAT TEST DATA EXCLUSIVITY HAS BEEN EXCLUDED FROM THE AGREEMENT}

During the negotiations of the TRIPs Agreement, the U.S. presented a proposal that would demand that all WTO member countries prohibit any use of test data without the consent of the data holder or without payment of a reasonable remuneration, if the referred use led to a commercial or competitive benefit by the government or any person involved. This proposal would oblige countries to bar any practice that generates such benefits.

That proposal, however, has been rejected, and, therefore, was not included in the TRIPs Agreement. The final text only bears the expression "unfair commercial use". As explained by Correa (2002), the refusal of the proposal presented by the United States indicates that the countries have deliberately opted for the regulation of certain practices - those that are commercially unfair - and not for barring any practice based in its possible effects - the generation of commercial benefits. Thus, the main concern of Article 39.3 of the TRIPs Agreement is to prevent unfair competition in the use of data and not to benefit third parties.

The U.S. proposal also explicitly provided the prohibition of relying on test data presented by the manufacturer of the reference product. Nevertheless, this concept was not included in the final text of the TRIPs Agreement. In this context, the history of the negotiation of Article 39.3 of the TRIPs Agreement is clear and does not support the thesis that the Agreement would have the intention of granting exclusivity rights for test data, but, on the contrary, shows that such an idea has been rejected by the countries (CORREA, 2002).

The protection against unfair commercial use does not prevent, thus, the registration of an equivalent medicine to the innovative drug from being granted based on safety and efficacy data presented by the first manufacturer. As seen above, the manufacturer of the equivalent product never has access to the originally produced data. They must only show that the medicine for which the market approval is requested is equivalent to the original already approved. 
ANVISA, in its turn, does not publicize or make available any test data presented by the manufacturer of the reference product, but relies on them to infer that, once the safety and efficacy of a medicine are proven, all equivalents will also be safe and effective.

Data exclusivity, however, would keep the regulating agency from relying on the results of test data presented by the original manufacturer for the registration of equivalent medicines during the term of the exclusivity - and that would be an unreasonable measure, not to mention contrary to the national policy of extensive access to medicines, as well as contrary to social, technological and economic development in Brazil.

In short, data exclusivity would be an additional and unreasonable protection by manufacturers of innovative products that hinders the registration of generic medicines and, consequently, puts health public based on the access to affordable quality medicine policies at risk. This additional protection is not derived from international treaties signed by Brazil, therefore there is no plausible reason for its adoption in Brazil.

There is, however, an incorrect interpretation according to which the Patent Act would grant to the manufacturer of an innovative drug this additional protection regarding crimes of unfair competition. As elucidated by Pedro Barbosa (2009), "Law no. 9.279/96 [the Patent Act] does not encompass - within patent law - any obligation cast upon clinical data and tests, but, regarding tutelage about competition fairness, it protects undisclosed data and tests". (translated from the original)

This data protection is present in the provisions of Article 195, XIV, of the Patent Act:

Article 195, Patent Act - A crime of unfair competition is committed by he who:

XIV - divulges, exploits or uses, without authorization, the results of tests or other undisclosed data the elaboration of which involved considerable effort and which has been presented to government entities as a condition for approving the commercialization of products.

This legal device provides protection against the unfair use of test data, as required by Article 39.3 of the TRIPs Agreement, but does not allow for any exclusivity rights over data.

However, as Pedro Barbosa (2009) points out, there is a measure of legal uncertainty derived from legal demands proposed by test data holders against manufacturers of generic medicines and against ANVISA itself, seeking to bar the utilization of those data for the market approval by third parties, based on the provisions of Article 195, XIV, of the Patent Act. ${ }^{233}$ 


\section{UN BODIES STATE THAT USE OF TEST DATA BY REGULATING AGENCIES DOES NOT CHARACTERIZE UNFAIR COMMERCIAL USE}

Those litigations are based on the understanding that ANVISA, while relying on test data presented by the manufacturer of the reference drug to infer the safety and efficacy of generic medicines, is committing an unfair competition offense.

The World Health Organization (OMS) (WHO, 2006) has already expressed their understanding that the use of test data by regulating agencies does not characterize unfair commercial use. ${ }^{234}$

Similarly, the United Nations Conference on Trade and Development (UNCTAD, 1996, p. 48), upon their analysis of Article 39.3 of the TRIPs Agreement, declared that "authorities are not prevented from using the knowledge of such data, for example, to analyze subsequent claims made by third parties to the registration of similar products". (translated from a Portuguese version)

Thus, the incorrect interpretation of Article 195, XIV, of the Patent Act, that it would grant data exclusivity and prevent ANVISA from registering generic medicines by relying on test data presented by the manufacturer of the reference medicine is contrary to the text of the Act, contrary to health public policies, contrary to what is determined by the WTO TRIPs Agreement, as well as its negotiation history, and contrary to the understanding of UN bodies.

\subsection{Legislative proposal}

For the above-mentioned reasons, we suggest the creation of a new paragraph to Article 195 of the Patent Act, worded as follows:

[Art. 195. A crime of unfair competition is perpetrated by anyone who:]

[XIV. divulges, exploits, or utilizes, without authorization, results of tests or other undisclosed data whose preparation involves considerable effort and that were submitted to government agencies as a condition for obtaining approval to commercialize products.]

$\$ 3$ The provision set forth under item XIV does not apply to the use, by government bodies, of test results or other undisclosed data, for market approval of products equivalent to the product for which they were initially presented. 


\subsection{Recommendations}

a) To Congress:

Approve Bill H.R. 5402/2013 to promote legal certainty through an express guarantee that it is not illegal the use by government bodies, of undisclosed test data for marketing approval for equivalent products related to the products that have been previously presented (see Art. 3 of Bill 5402/2013, attached, that amends Art. 195 of the Patent Act).

b) To the Executive Branch:

b.1) to the Sanitary Agency - ANVISA:

Keep on using test data from the reference product for equivalence tests, without the fear that this practice may be argued as illicit.

\section{b.2) to the Competition Agency - CADE:}

Tackle anti-competitive and abusive practices caused by test data exclusivity that may block the entry of products in the market or harm market competition, and duly investigate and apply due sanctions. 


\section{SHAM LITIGATION}

The generic and similar medicines policy began in the United States in the 1980's and has been growing exponentially, making a deep impact on the dynamics of the pharmaceutical market all over the world. The introduction of generics plays a fundamental role in the expansion of and access to lower-priced medicines, and consists on an important policy with profound social impact; especially for the low-income portion of the population.

It was not different in Brazil, and policies encouraging generic medicines were included in the Brazilian legislation through the following acts: Law no. 6.360/76 (on the sanitary guidelines to which medicines are subject), the Patent Act (no. 9279/96) and the most scathing, Law no. 9.787/99 (Generic Medicines Act).

In this context, beginning in 2000, the year generic medicines were launched, the generics market has been growing substantially (with rates of over $10 \%$ a year) and, consequently, increasing their penetration in the Brazilian market. Thus, the introduction of this kind of medicine has been playing a strategic role in encouraging competition and the development of the pharmaceutical sector, promoting less disparity in the pharmaceutical sector market.

An European study on the pharmaceutical industry outlined those changes in market dynamics and pointed to a reactive movement by the large pharmaceutical companies to block or inhibit the entry of generic medicines. ${ }^{235}$

This reactive movement against generic medicines is well organized and outlined, with lawsuits in the administrative, legal, regulatory and economic (competition) spheres. Almost all great pharmaceutical companies systematically and simultaneously use those lawsuits with the goal of trying to block the entry of generic medicines.

Over the last few years there has been an intensification of those strategies, due to: i) generic sales increase, ii) expansion of competitive potential of manufacturers of generic medicines, iii) loss of market space by large pharmaceutical companies, iv) scarcity in the development of innovative medicine and, chiefly, v) the end of patent terms for highly relevant medicines.

The biggest and most visible issue caused by the practice of abusive lawsuits, also known as sham litigations, is the barrier it established against the full access to medicines, to the production of generics and to free competition. 
With the end of the monopoly of great pharmaceutical industries, which generated significant advances in competition in the pharmaceutical market, consequently, there was a noticeable increase in the number of unfair competition lawsuits in the sector.

The Brazilian legislation that deals with abusive market practices has not been preventing the reckless and indiscriminate use of the Brazilian legal system in lawsuits aimed at stalling the entry of generic medicines in the market and has been causing huge legal uncertainty for manufacturers of generics. Therefore, the limitation of competition in the pharmaceutical sector generates huge economic, social and technological losses for the country, whether by maintaining abusive prices, or by inhibiting the development of national companies in the market.

Abuse through lawsuits is not exclusive to the pharmaceutical-chemical field. The media has been reporting many disputes between Apple and Samsung regarding cellular telephone patents.

The Brazilian High Court of Justice (Superior Tribunal de Justiça - STJ) convicted Microsoft of abuse of surveillance rights. A technical services company was inspected upon Microsoft's application, which claimed that the company used Microsoft software illegally. After the surveillance, however, there was no irregularity in the more than 300 computer software programs used in the company. The company did not even use Microsoft software. It was, therefore, a crass mistake on Microsoft's part (Resp. 1114889).

The patent system was created as a means to encourage innovation and economic, social and technological development. As such, it must not be unduly employed to inhibit competition through reckless suits and/or abuse of rights.

\subsection{Recommendations}

\section{a) To the Executive Branch:}

\section{a.1) to the Competition Agency - CADE:}

Tackle anti-competitive practices and act energetically towards curbing anticompetitive behavior and abuses in the field of patents and related rights. 


\section{COMPULSORY LICENSE}

The patent system instituted by the TRIPs Agreement allows WTO member countries to adopt necessary measures to protect public health and to promote public interest in sectors of vital importance for their economic and technological development (Article 8). ${ }^{236}$ Compulsory license, usually known by the incorrect term "patent infringement", is one of those measures. ${ }^{237}$ Compulsory license can be used not just in cases of public interest but also as a market tool to restrain anti-competition practices or in cases of dependent patents, for instance - see chart in this chapter.

Compulsory license suspends the temporary legal monopoly created by the patent, allowing its object to be imported, produced or commercialized by any agents in the country without the authorization of the right holder, upon payment of royalties. Guise (2006, p. 103) defines it as follows: "compulsory license is the tool that, without implicating the suppression of the patent holder's rights, corrects the exercise of the abusive exclusivity rights and ensures the procurement of public interests".

TRIPs deals with compulsory licenses in its Article 31, which deals with "other use without authorization of the right holder". This article lists conditions that must be present for the use of a compulsory license and that must be defined by each member country in their respective national legislations, in accordance with each country's national interests (WTO, 1994).

The Art. 31 of the TRIPs is worded as follows:

TRIPs Agreement. Article 31. Other uses without authorization of the right holder.

Where the law of a Member allows for other use of the subject matter of a patent without the authorization of the right holder, including use by the government or third parties authorized by the government, the following provisions shall be respected:

(a) authorization of such use shall be considered on its individual merits;

(b) such use may only be permitted if, prior to such use, the proposed user has made efforts to obtain authorization from the right holder on reasonable commercial terms and conditions and that such efforts have not been successful within a reasonable period of time. This requirement may be waived

236 Article 8, Principles:

1. Members may, in formulating or amending their laws and regulations, adopt measures necessary to protect public health and nutrition, and to promote the public interest in sectors of vital importance to their socio-economic and technological development, provided that such measures are consistent with the provisions of this Agreement.

2. Appropriate measures, provided that they are consistent with the provisions of this Agreement, may be needed to prevent the abuse of intellectual property rights by right holders or the resort to practices which unreasonably restrain trade or adversely affect the international transfer of technology.

237 The expression "patent infringement" is technically incorrect because it gives an incomplete and wrong idea about compulsory licenses. These licenses do not constitute an infringement or termination of the rights of patent holders. After the compulsory license, ownership remains in the name of who owns the patent rights. What happens is that the use of the patent's subject matter does not depend anymore on prior authorization from the holder. But several requirements must be fulfilled so that the license is granted. In addition, the holder receives, indeed, remuneration for the use of the patent. 
by a Member in the case of a national emergency or other circumstances of extreme urgency or in cases of public non-commercial use. In situations of national emergency or other circumstances of extreme urgency, the right holder shall, nevertheless, be notified as soon as reasonably practicable. In the case of public non-commercial use, where the government or contractor, without making a patent search, knows or has demonstrable grounds to know that a valid patent is or will be used by or for the government, the right holder shall be informed promptly;

(c) the scope and duration of such use shall be limited to the purpose for which it was authorized, and in the case of semi-conductor technology shall only be for public non-commercial use or to remedy a practice determined after judicial or administrative process to be anti-competitive;

(d) such use shall be non-exclusive;

(e) such use shall be non-assignable, except with that part of the enterprise or goodwill which enjoys such use;

(f) any such use shall be authorized predominantly for the supply of the domestic market of the Member authorizing such use;

(g) authorization for such use shall be liable, subject to adequate protection of the legitimate interests of the persons so authorized, to be terminated if and when the circumstances which led to it cease to exist and are unlikely to recur. The competent authority shall have the authority to review, upon motivated application, the continued existence of these circumstances;

(h) the right holder shall be paid adequate remuneration in the circumstances of each case, taking into account the economic value of the authorization;

(i) the legal validity of any decision relating to the authorization of such use shall be subject to judicial review or other independent review by a distinct higher authority in that Member;

(j) Members are not obliged to apply the conditions set forth in subparagraphs (b) and (f) where such use is permitted to remedy a practice determined after judicial or administrative process to be anti-competitive. The need to correct anti-competitive practices may be taken into account in determining the amount of remuneration in such cases. Competent authorities shall have the authority to refuse termination of authorization if and when the conditions which led to such authorization are likely to recur;

(k) any decision relating to the remuneration provided in respect of such use shall be subject to judicial review or other independent review by a distinct higher authority in that Member;

(l) where such use is authorized to permit the exploitation of a patent ("the second patent") which cannot be exploited without infringing another patent ("the first patent"), the following additional conditions shall apply:

(i) the invention claimed in the second patent shall involve an important technical advance of considerable economic significance in relation to the invention claimed in the first patent; 
(ii) the owner of the first patent shall be entitled to a cross-license on reasonable terms to use the invention claimed in the second patent; and

(iii) the use authorized in respect of the first patent shall be non-assignable except with the assignment of the second patent.

\section{TYPES OF COMPULSORY LICENSES AVAILABLE IN BRAZIL238}

1. exercising patent rights in an abusive manner (Art. 68);

2. abusing of economic power by means of a patent (Art. 68);

3. failing to manufacture or insufficient manufacture of the patent object in Brazilian territory, or failing to use the entirety of the patented process except for cases of economic non-feasibility (Art. 68);

4. commercializing the patented product in such a way that it fails to meet market demand (Art. 68);

5. dependent patents (Art. 70);

6. national emergency declared by the Federal Executive Branch (Art. 71) ${ }^{239}$;

7. public interest declared by the Federal Executive Branch (Art. 71). ${ }^{240}$

There are a handful of bills (Bills H.R. 139/1999, 3562/2000, 303/2003, 5176/2009 and 2975/2004) at the Chamber of Deputies that aim at increasing the possibilities of use of compulsory licenses such as when there is canceling or temporary suspension of commercialization or production of medicines, or to extend its use to all cases in which there is no local working in the national territory, withdrawing the reservation of economic unfeasibility.

Two decrees have regulated the compulsory licensing provided by Article 71 of the Brazilian Patent Act. In 6 October 1999, then President Fernando Henrique Cardoso signed Decree 3.201, which allows the Ministries to issued compulsory licenses in cases of national emergency (Official Gazette, 1999, Article 3).

In 4 de September 2003, then President Luiz Inácio Lula da Silva edited Decree 4.830, with the introduction of important changes in the previous decree, allowing the import

238 Compulsory license is the technical term as provided for in the Patent Act. The press in Brazil usually refers to compulsory licenses as "patent infringement" (quebra de patente), although it is not correct from a legal standpoint. Referring to compulsory licenses as "patent infringement" is not correct as the patent remains valid and held by its patent holder. Moreover, a mandatory payment of royalties for the use of the compulsorily licensed patent is due, as well as several legal requirements shall be observed. The difference regarding patents that were not compulsorily licensed is that their use can only occur after previous authorization by its holder. As for compulsorily licensed patents, there is no need for previous authorization, although royalties must be paid for its use, and the requirements established by the legislation must also be observed.

239 The hypotheses of compulsory license grant stipulated in the Article 71 of the Patent Act were regulated by Decree 3.201/99.

240 Idem. 
of generic versions of compulsorily licensed products any time domestic production proves non-feasible and mandating the patent holder to reveal all necessary information for such production (Official Gazette, 2003). This Decree increased the Brazilian government's bargain power even more regarding pharmaceutical multinationals in the negotiation of the prices of patented antiretrovirals used in the treatment of AIDS.

The sustainability of the Brazilian AIDS treatment program, pioneering in the world for its gratuity and universality, has been ensured by the domestic production of generics, which not only allows for the replacement of imports of expensive antiretrovirals not patented in Brazil, but also encourages significant discounts from pharmaceutical multinationals for antiretrovirals patented in the country as this companies' responses to the government's threats of compulsorily licensing patents of medicines used in the treatment of AIDS.

While commenting on frequently abusive prices, or the fact that they are completely unrelated to expenses with R\&D, the Commission on Intellectual Property Rights of the Government of the United Kingdom alerted that " $\mathrm{t}]$ he patent system cannot stimulate inventions that are useful to society if the potential beneficiaries cannot pay for them, or someone else is not prepared to pay on their behalf." ${ }^{241}$

As a result of the discounts granted by pharmaceutical multinational companies, the Ministry of Health's expenses with antiretroviral therapies dropped from US\$336 million in 1999 to US\$ 167 million in 2002, in spite of the considerable increase in treated patients, from 79.245 to 119.500 . The increased competition between antiretrovirals suppliers generated by national production by Brazilian public laboratories gave way to considerable savings by the Government. ${ }^{242}$

241 See United Kingdom, Commission on Intellectual Property Rights (CIPR), Integrating Intellectual Property Rights and Development Policy, London, 2002.

242 The savings were not generated solely by the reduction on expenses with antiretroviral medicine but also by the significant drop on the number of hospital admittances related to AIDS. The ratio of hospitalizations and treated patients dropped from 1.65 in 1996 to 0.24 in 2001 (MELLO E SOUZA, 2007, p. 48). 


\section{THE EFAVIRENZ CASE}

Partly because of some pharmaceutical multinationals' discontinuation of satisfactory discounts on prices of patented antiretrovirals, in 4 May 2007, Brazil issued their first compulsory license, for the antiretroviral efavirenz, commercialized by the multinational laboratory Merck. This license was initially valid for fiver years and has been recently renewed for five more. It was the first case of compulsory licensing of an antiretroviral in the Americas; Thailand, however, had already established the precedent by issuing compulsory licenses for the same antiretroviral, efavirenz, in November 2006, and for the combination lopinavir/ritonavir, by the Abbott laboratory, in January 2007. ${ }^{243}$

This Brazilian compulsory license established remuneration to Merck of $1.5 \%$ over the final product price by way of royalties. The generic version of the drug was initially imported from India. In January 2009, however, the national production of efavirenz was announced by public laboratory Farmanguinhos. There was, however, an eight-month delay in the domestic production of the medicine - as its active principle is produced by a Brazilian consortium that includes the laboratories Nortec, Cristália and Globe. The price of the national version, although less than half Merck's price, is higher than the same generic's in India, which evidences the scarcity of investments in technological training in the Brazilian pharmaceutical sector.

With the compulsory licensing of efavirenz, the Ministry of Health saved over $\mathrm{R} \$ 200$ million between 2007 and 2011, an economy of 58,47\% in relation to what they would have spent on the purchase of Merck's patented product. ${ }^{244}$

Several NGOs and national, foreign and transnational activist groups, which had been suggesting the compulsory licensing of antiretrovirals in Brazil for about ten years, applauded the measure. The activists underlined the legality and legitimacy of the issued compulsory license and suggested that the suspension of the legal monopoly of some antiretroviral patents would help the propagation of the practice in the country and in other developing countries, prompting an increase in the offer of generics at affordable prices in the market and, consequently, the access to essential medicines. ${ }^{245}$ In contrast, pharmaceutical multinationals and the governments of some countries, chiefly the United States, considered the compulsory licensing of efavirenz unnecessary

243 For a discussion about compulsory licenses granted in Thailand, Brazil, Canada and Rwanda, see Laurence Helfer and Graeme Austin, "Human Rights and Intellectual Property: Mapping the Global Interface", Cambridge, 2011, pp. 127-138.

244 Francisco Viegas Neves DA SILVA; Ronaldo HALLAL and André GUIMARÃES. Compulsory License and Access to Medicines: Economics Savings of Efavirenz in Brazil. Presented during the XIX International AIDS Conference, 2012. Available at http://pag.aids2012.org/PAGMaterial/aids2012/PPT/940_3379/cl\%20 efv\%20final.pptx

245 See Abaixo assinado em Apoio à Emissão da Licença Compulsória do Medicamento Efavirenz, available in Portuguese at http://www.rebrip.org.br/_rebrip/pagina.php?id=1496. 
and threatened to cut back on investments in Brazil. According to the president of the U.S. Chamber of Commerce, Mark Smith, the measure would make it difficult to keep Brazil in the Generalized System of Preferences, a program of fiscal benefits through which Brazil exports a yearly US\$ 3,5 billion to the United States.

The compulsory license mechanism has been used in several situations and in several countries, including technologically developed countries. ${ }^{246}$ Although they are publicly against the issuance of compulsory licenses for the treatment of diseases such as AIDS, developed countries like the United States of America, for instance, have made use or threatened to use the mechanism of compulsory license several times when they were intended as a guarantee for their interests. ${ }^{247}$

\section{LOCAL WORKING REQUIREMENT}

In response to the actions of the Brazilian government regarding the production of highly profitable antiretroviral patented by or licensed exclusively to companies from the United States, the government of the U.S. initiated an inquiry at the WTO against Brazil in 1 February 2001. The stated reason was Article 68, § 1, item I, of the Brazilian Patent Act.

The Article in question determines that "the non-exploitation of the subject matter of the patent in the territory of Brazil, by lack of manufacture or incomplete manufacture of the product or, furthermore, by lack of complete use of a patented process, except in the case of non-exploitation due to economic unviability, when importation will be admitted" (Patent Act, 1996). In other words, if the object of patent is not locally produced or if it is produced only partially in Brazil, the patent can be compulsorily licensed. Which means, in practice, an incentive to technological training in Brazil in order to meet the demand of the patent clause of the Brazilian Constitution (Art. $\left.5^{\circ}, X X I X\right)$, that the patent system promotes the country's technological, economic and social development.

Brazil does not want to be a mere buyer of finished (and patented) products. It wants there to be technology transfer and technology training in the country. Otherwise, we will eternally be buyers of finished products without ever developing technology in our country. That is why the clause about local production is so important.

Representatives of the United States have argued, however, that this article violated Article 27.1 of TRIPs, according to which "patent rights [are] enjoyable without discrimination as to the place of invention, the field of technology and whether products are imported or locally produced."

246 See study by the Knowledge Ecology International - KEI, Recent examples of the use of compulsory licenses on patents available at http://www.keionline.org/misc-docs/recent_cls.pdf. Access: 22 January 2009.

247 The Government of the U.S. announced that they would use the compulsory license in the widely know case of the drug Cipro, by Bayer, in occasion of biological attacks with anthrax in the United States. See Adam B. JAFFE e Josh LERNER, Innovation and Its Discontents - How our Broken Patent System is Endangering Innovation and Progress, and What to Do About it, Princeton, 2004, p. 17. 
The United States Trade Representative argued that "Article 68 is not related to health and access to medicines, but everyone discriminates against imported products and favors Brazilian products. In summary, Article 68 represents a protectionist measure that aims to create jobs for Brazilian" (USTR, 2001, at 10). (translated from a Portuguese version)

Brazil expressed the counter-argument that our Patent Act follows the rulings of the Paris Convention, pointing to Article 2.1 of the TRIPs Agreement, which explains: "in respect of Parts II, III and IV of this Agreement, Members shall comply with Articles 1 through 12, and Article 19, of the Paris Convention (1967)" (WTO, 1994).

Without local manufacturing of the patent object, Brazil becomes a mere consumer and packer of others' technology. Using the patent as a tool for retaining exclusivity of rights, preventing the use, production and commercialization by third parties, without, however, the patent holder actually exploring the object in national territory, is clearly contrary to the patent clause of the Brazilian Constitution, as well as to the TRIPs Agreement (Articles 7 and 8), and to the goals of the Patent Act (Art. 2) and the patent system itself.

This practice (using the patent as a way of obtaining exclusivity of rights, barring the use, production and commercialization by third parties, without, however, the exploration of its object in national territory by the patent holder) is a clear form of abuse of rights which, in fact, is restrained by the national judicial order, besides being expressly dealt with both in the Patent Act (Art. 68) and the founding act of the Brazilian System of Competition Defense (Act 12.529/2011).

One way or another (whether through the absence or insufficiency of local production; whether by means of abuse of rights), the patent object that is not locally manufactured can and should, if necessary to rebalance public and private interests, be compulsorily licensed.

In that regard, China, in 2008, reviewed their patent act exactly to accommodate a similar measure to Brazil. If the patent holder, in that country, after three years from the granting date and four years after the filing date, still has not explored or sufficiently explores the patent object without justified reason, a compulsory license can be issued. ${ }^{248}$

Another issue regarding compulsory licenses is an additional obstacle imposed by TRIPs to global access to essential medicines. Relatively less developed countries that do not have pharmaceutical laboratories capable of producing compulsorily license medicines depend on their imports. However, Article 31 (f) of the TRIPs Agreement states that compulsory licensing in a member country can only be done with the aim of primary supply to this country's domestic market (WTO, 1994). That would 
mean, for instance, that countries such as Brazil and Thailand, that issued compulsory licenses for antiretrovirals, would not be able to export those antiretrovirals to countries that are incapable of producing them nationally in larger quantities than what is sold domestically.

The Doha Declaration has left this problem without a solution; however, in it Paragraph 6 , it recognizes that "WTO members with insufficient or no manufacturing capacities in the pharmaceutical sector could face difficulties in making effective use of compulsory licensing under the TRIPS Agreement" and determined that the Council for TRIPs "find an expeditious solution to this problem" (WTO, 2001).

In 30 August 2003, prior to the WTO Ministerial in Cancun, Brazil was one of the four developing countries to build an agreement about legal changes before the WTO that allowed least developed countries - which, therefore, had limited capacity or no capacity of production of essential medicines locally - to import generic and cheaper versions of those medicines produced by means of compulsory licensing in other countries. ${ }^{249}$

According to the agreement, which was adopted by the Council for TRIPs, those imports have to be approved by the WTO and the medicine in question has to be compulsorily licensed in both countries, the exporter and the importer, and the packaging must be clearly identifiable to avoid smuggling for other countries - which was severely criticized by specialists, who understand that such procedures have created excessively complex rules. ${ }^{250}$ In that context, the procedure provided in that agreement allowing the international trade of a compulsorily licensed medicine has only happened once so far, between Canada and Rwanda. ${ }^{251}$

In 6 December 2005, the WTO member countries agreed to make those legal changes permanent through a formal amendment to the TRIPs Agreement that will come into force after being ratified by two thirds of the 157 WTO members. Up until now, 43 countries and the European Union (representing 27 countries) have ratified the amendment. Brazil ratified the amendment in 13 November 2008. Until the amendment

249 See WORLD TRADE ORGANIZATION, Implementation of paragraph 6 of the Doha Declaration on the TRIPS Agreement and public health - Decision of the General Council of 30 August 2003, General Council, WT/L/540 and Corr.1, 1 September 2003, available at https://www.wto.org/english/tratop_e/trips_e/ implem_para6_e.htm. Access in 29 October 2012.

250 See Laurence HELFER and Graeme AUSTIN, op. cit., pp. 124-125, and Frederick M. ABBOTT and Jerome H. REICHMAN, Doha Round's Public Health Legacy: Strategies for the Production and Diffusion of Patented Medicines under the Amended TRIPs Provisions, 10 J. Intl. Econ, L. 921, 2007, pp. 921 e 932.

251 See William New, WTO General Council Extends Deadline For TRIPS Health Amendment, 01.12.2011, available at http://www.ip-watch.org/2011/12/01/wto-general-council-extends-deadline-for-trips-healthamendment/. Access: 29 October 2012. 
comes into force, with the ratification of two thirds of the WTO member countries, the decision of 30 August 2003 remain in full force in all member countries. ${ }^{252}$

The possibilities of use by Brazil of the mechanism agreed upon at the WTO in 20 August 2003 to import antiretrovirals compulsorily licensed in other countries are not very promising. The WTO's demands and the complexity of the mechanism are such as admit Canadian exporters themselves, which were the only ones using it so far - that it becomes too costly and impracticable, except as an emergency measure. ${ }^{253}$

Another independent option that is not directly related to the discussion above is the issuance of compulsory licenses based in anti-competition practices, which are exempt from the demands of Article 31(f) of the TRIPs Agreement. Article 3l(k) of the TRIPs Agreement states that " $[\mathrm{m}]$ embers are not obliged to apply the conditions set forth in subparagraphs (b) and (f) where such use is permitted to remedy a practice determined after judicial or administrative process to be anti-competitive." (WTO, 1994).

Concerning the anti-competition aspects regarding technology and patents, Act 12.529/2011, establishing the Brazilian System for the Defense of Competition, lists several conducts that are characterized as infringements of the economic order (Art. 36. and items V, VIII, XI, XIV, XVIII, XIX), transcribed as follows:

Art. 36. The acts which under any circumstance have as an objective or may have the following effects shall be considered violations to the economic order, regardless of fault, even if not achieved:

I - to limit, restrain or in any way injure free competition or free initiative;

II - to control the relevant market of goods or services;

III - to arbitrarily increase profits; and

IV - to exercise a dominant position abusively.

$\$ 1$ Achieving dominance in a market by natural process and by being the most efficient economic agent in relation to competitors does not characterize the tort set forth in item II of the caput of this article.

$\$ 2$ A dominant position is assumed when a company or group of companies is able to unilaterally or jointly change market conditions or when it controls $20 \%$ (twenty percent) or more of the relevant market, provided that such percentage may be modified by Cade for specific sectors of the economy.

$\$ 3$ The following acts, among others, to the extent to which they conform to the principles set forth in the caput of this article and its clauses, shall characterize violations of the economic order:

252 See WORLD TRADE ORGANIZATION, Members accepting amendment of the TRIPS Agreement, available at https://www.wto.org/english/tratop_e/trips_e/amendment_e.htm. Access: 29 October 2012, and WORLD TRADE ORGANIZATION, Members and Observers, available at https://www.wto.org/english/ thewto_e/whatis_e/tif_e/org6_e.htm. Access: 29 October 2012.

253 See Abbott e Reichman, op. cit., loc. cit. 
I - to agree, join, manipulate or adjust with competitors, in any way:

a) the prices of goods or services individually offered;

b) the production or sale of a restricted or limited amount of goods or the provision of a limited or restricted number, volume or frequency of services;

c) the division of parts or segments of a potential or current market of goods or services by means of, among others, the distribution of customers, suppliers, regions or time periods;

d) prices, conditions, privileges or refusal to participate in public bidding;

II - to promote, obtain or influence the adoption of uniform or agreed business practices among competitors;

III - to limit or prevent the access of new companies to the market;

IV - to create difficulties for the establishment, operation or development of a competitor company or supplier, acquirer or financier of goods or services;

$\mathrm{V}$ - to prevent the access of competitors to sources of input, raw material, equipment or technology, and distribution channels;

$\mathrm{VI}$ - to require or grant exclusivity for the dissemination of advertisement in mass - 14/34 - media;

VII - to use deceitful means to cause oscillation of prices for third parties;

VIII - to regulate markets of goods or services by establishing agreements to limit or control the research and technological development, the production of goods or services, or to impair investments for the production of goods or services or their distribution;

IX - to impose on the trade of goods or services to distributors, retailers and representatives, any resale prices, discounts, payment terms, minimum or maximum quantities, profit margin or any other market conditions related to their business with third parties;

$\mathrm{X}$ - to discriminate against purchasers or suppliers of goods or services by establishing price differentials or other operating conditions for the sale or provision of services;

$\mathrm{XI}$ - to refuse the sale of goods or provision of services for payment terms within normal business practice and custom;

XII - to hinder or disrupt the continuity or development of business relationships of undetermined term, because the other party refuses to abide by unjustifiable or anticompetitive terms and conditions;

XIII - to destroy, render useless or monopolize the raw materials, intermediate or finished products, as well as to destroy, disable or impair the operation of equipment to produce, distribute or transport them;

XIV - to monopolize or prevent the exploitation of industrial or intellectual property rights or technology;

$\mathrm{XV}$ - to sell goods or services unreasonably below the cost price;

XVI - to retain goods for production or consumption, except to ensure recovery of production costs; 
XVII - to partially or totally cease the activities of the company without proven just cause;

XVIII - to condition the sale of goods on the acquisition or use of another good or service, or to condition the provision of a service on the acquisition or use of another good or service; and

XIX - to abusively exercise or exploit intellectual or industrial property rights, technology or trademark.

(emphasis added)

The Competition Body (CADE), as well as the Judiciary, have legal grounds to prevent and punish anti-competition acts in the scope of patents and general technologies. In that regard, in fact, the U.S. has issued compulsory licenses in more than 100 anti-trust cases in that country. ${ }^{254}$

In spite of the benefits brought by the compulsory licensing of efavirenz, which resulted in economy of public resources from the purchase of generic medicines, this has been the only compulsory license granted in the country.

President Dilma Rousseff ${ }^{25}$, during a speech delivered at the High-Level Meeting about Non-Transmissible Chronic Diseases hosted in September 2011 by the United Nations and by the World Health Organization, defended the use of the TRIPs flexibilities also in the context of those diseases, going further than the case for HIV/AIDS. The compulsory license is a measure that can lessen the negative impacts made by the temporary legal monopoly on the access to essential medicines and should be used whenever necessary for the promotion of public interests. We suggest, however, that Brazil not only uses compulsory licenses, but also produces locally the medicines that are essential to the population.

254 See Commission on Intellectual Property Rights. Integrating intellectual property rights and developing policy, Report of the Commission on intellectual property rights, London, UK 2002.

255 Available at: http://www2.planalto.gov.br/imprensa/discursos/discurso-da-presidenta-da-republicadilma-rousseff-na-abertura-da-reuniao-de-alto-nivel-sobre-doencas-cronicas-nao-transmissiveis-novaiorque-eua. 


\subsection{Recommendations}

a) To the Executive Branch:

a.1) to the Competition Agency - CADE:

Tackle anti-competitive practices and act energetically towards curbing anticompetitive behavior and abuses in the field of patents and related rights, and recommend the issuance of compulsory licenses if necessary for the correction, in a case by case basis, of abusive or anti-competitive behavior.

\section{a.2) to the Inter-ministerial Group on Intellectual Property - GIPI:}

Create a workgroup to discuss all the possibilities of compulsory licensing in Brazil, as provided for in the Patent Act, in the Brazilian System of Competition Defense, as well as in the TRIPs Agreement, in order to lead a comparative study on how other countries, such as Thailand, India, Canada, United States and Argentina, for instance, have been applying in practice the compulsory license mechanism, in order for the GIPI to create guidelines, to support the Federal Executive Branch in taking measures related to compulsory licenses in the country.

\section{a.3) to the President's Office:}

In case there is no local production or insufficient local production of the patent, apply the provision as set forth in Art. 68 of the Patent Act and issue a compulsory license due to lack of local production - with the aim of promoting capacitybuilding and technology transfer. 


\section{GENETIC RESOURCES, TRADITIONAL KNOWLEDGE, AND BENEFIT SHARING}

The use of genetic resources and/or traditional knowledge of autochthonous populations is a highly relevant theme. While countries that are presently technologically developed seek to expand (increasingly so) patent rights and related rights, not just within their own countries, but also in the international sphere, those very technologically developed countries practice bio piracy in large scale. In other words, they appropriate genetic resources and/or traditional knowledge from countries with rich fauna, flora and natural resources and populations in possession of information about the use of the traditional knowledge, without, however, asking for previous authorization to use the genetic resources or traditional knowledge, and without equitable sharing of the accrued benefits.

There are several cases of improper and unauthorized use, also without equal sharing of the accrued benefits, precisely of genetic resources or traditional knowledge found in least technologically developed countries, where most of the fauna and flora of the plant is, and where a large part of traditional culture and knowledge transmitted from generation to generation are.

We do not advocate for the prohibition of use of genetic resources and traditional knowledge, but for a balanced use, not only in respect to the environment but also to local populations. To that end, an independent empirical study must be undertaken to map the situation and so that regulations in this field fulfill all interests involved in a balance and just manner.

That is the theme of this chapter.

\subsection{International legislations}

Some international regimes constitute a legal framework that regulates the protection and use of genetic resources in signatory countries. Among those regimes, the most relevant are the Trade-Related Aspects of Intellectual Property Rights (TRIPs), the International Union for the Protection of New Varieties of Plants (UPOV), the Convention on Biological Diversity (CDB), and the International Treaty on Plant Genetic Resources for Food and Agriculture of FAO - Food and Agriculture Organization (TIRFAA-FAO).

The United Nations Conference on Environment and Development, which took place in Rio de Janeiro in 1992 (the Earth Summit, or ECO-92), produced the Convention on Biological Diversity (CDB), which determines, already in the Paragraph $j$ of its Article 8 , that each contracting party must, 
[...] subject to its national legislation, respect, preserve and maintain knowledge, innovations and practices of indigenous and local communities embodying traditional lifestyles relevant for the conservation and sustainable use of biological diversity and promote their wider application with the approval and involvement of the holders of such knowledge, innovations and practices and encourage the equitable sharing of the benefits arising from the utilization of such knowledge, innovations and practices. ${ }^{256}$

Paragraph 5 of Article 15 of the Convention, in its turn, establishes that "[a]ccess to genetic resources shall be subject to prior informed consent of the Contracting Party providing such resources, unless otherwise determined by that Party." 257 The CBD connects, then, conservation and the sustainable use of the planet's biodiversity to the protection of traditional knowledge. Similarly, the Convention recognizes the rights of the communities that possess traditional knowledge of sharing their economic benefits as long as there is prior consent.

The CBD also proclaims the countries' sovereignty over biological resources found in their territories. Paragraph 1 of Article 15 recognizes "the sovereign rights of States over their natural resources, the authority to determine access to genetic resources rests with the national governments and is subject to national legislation." ${ }^{258}$ Paragraph 7 of the same Article establishes that

Each Contracting Party shall take legislative, administrative or policy measures, [...] with the aim of sharing in a fair and equitable way the results of research and development and the benefits arising from the commercial and other utilization of genetic resources with the Contracting Party providing such resources. Such sharing shall be upon mutually agreed terms. ${ }^{259}$

The recognition by the CBD of both the rights of communities in possession of traditional knowledge as well as the sovereign rights of the countries regarding the access to its genetic resources has been incurring on important political implications. A CBD was originally signed by 150 countries and subsequently ratified by 187 countries, which makes it one of the international agreements with the largest number of members (Secretariat of the Convention on Biological Diversity, 2000).

Most developed countries signed and ratified the Convention. The U.S., however, against the pleas and expectations of many environmentalist groups in 1994 (Simmons,

256 Convention on Biological Diversity, 1992. Available at http://www.cbd.int/doc/legal/cbd-en.pdf.

257 Op. cit, loc. cit.

258 Op. cit, loc. cit.

259 Op. cit, loc. cit. 
1998, p.82) and in response to the pressures of biotechnology industries, did not ratify the Convention, with the claim that it threatens patent and related rights guaranteed in that country and in the TRIPs Agreement (Cano, 1992, p.381; Coghlan, 1992), which is a clear rhetorical argument to protect their national industry and disrespect traditional knowledge and genetic resources of the other countries, as well as the evolution of the treatment of this issue in the international sphere.

Nonetheless, the Seventh Conference of the CBD Parties, which took place in Kuala Lumpur, in Malaysia, in February 2004, opted for the creation of a new workgroup with the specific mandate of negotiating the terms of a legally binding regime regarding the right of autochthonous and local communities to the control of the access to genetic resources and traditional knowledge, as well as over the sharing of benefits accrued from those resources and knowledge. ${ }^{260}$ During the eighth Conference of the Parties, which took place in 2006 in Curitiba, in Brazil, the members of CDB stipulated a final deadline for the year of 2010 for the negotiation of this regime.

At the tenth Conference of the Parties, which took place in 2010 in Nagoya, Japan, a protocol was approved recognizing the countries' sovereignty over genetic resources of their biodiversity and that the access to this biodiversity can only be granted upon consent from those countries. The agreement approaches the question of just and equitable sharing of the benefits accrued from the use of genetic resources, supported by the standpoint of technology transfer and proper financing, and representing, in the words issued by the Ministry of Foreign Relations, "an important step for the conservation of biodiversity in the global sphere and against bio piracy, with special relevance for countries such as Brazil, in possession of elevated biological piracy." Brazil signed the Protocol in 2 February 2011. ${ }^{261}$

In addition, in case the access results in the elaboration of a product, the profits yielded by its production and commercialization will necessarily be shared with the country of origin. However, the Nagoya Protocol did not guarantee facilitated access to justice in case of infringement or the denial of foreign patent applications for genetic resources and associated knowledge, as desired by many developing countries (Convention on Biological Diversity, 2010). As a result from this defeat for the countries in possession of a great range of the planet's biodiversity, such consent remains an obligation merely by national laws, and the sharing of benefits is done in a case by case basis.

260 The creation of the said international regime had already been recommended by Bonn's Good Practices Guide, adopted by the 6th Conference of the Parties to the CBD, as well as by the Implementation Plan approved during the World Summit on Sustainable Development, held in Johannesburg, South Africa, in 2002.

261 Ministry of Foreign Affairs (MRE), note 41, "Assinatura do Protocolo de Nagoia sobre Acesso e Repartição de Benefícios", available in Portuguese at http://www.itamaraty.gov.br/sala-de-imprensa/notas-a-imprensa/ assinatura-do-protocolo-de-nagoia-sobre-acesso-e-reparticao-de-beneficios and CDB, Protocolo de Nagoia sobre Acesso a Recursos Genéticos e a Repartição Justa e Equitativa dos Benefícios Advindos de sua Utilização, available in Portuguese at http://www.cbd.int/abs/text/. 
Regarding biological resources and biotechnology, Paragraph 3(b) of Article 27 of the TRIPs Agreement rules that members can deem non-patentable:

[...]plants and animals other than micro-organisms, and essentially biological processes for the production of plants or animals other than nonbiological and microbiological processes. However, Members shall provide for the protection of plant varieties either by patents or by an effective sui generis system or by any combination thereof. The provisions of this subparagraph shall be reviewed four years after the date of entry into force of the WTO Agreement. ${ }^{262}$

In the scope of the discussions relative to the review of Article 27.3(b), developing countries have been arguing that there is inconsistency between TRIPs and the CDB. The chief reason for concern of some of those countries in this respect is that the TRIPs Agreement does not demand from applicants of patents which include genetic material or traditional knowledge the fulfillment of the obligations agreed upon the CDB.

The demands for prior consent from the Contracting Party provider of genetic material and associated knowledge and the just and equitable sharing with this party of the benefits accrued from its utilization are absent from the TRIPs Agreement. With the goal of harmonizing the TRIPs Agreement and the CDB, the developing countries have been proposing in the Council of TRIPs the amendment of such agreement, but this proposal has been getting rejections from several developing countries (Plahe and Nyland, 2003; UNCTAD-ICTSD, 2005), in a clear situation of "two weights, two measuring units", seeing as, for the advanced technologies to which developing countries have training, the same would require more protection, but for genetic resources and involved traditional knowledge, present, for the most part, in developing countries, there is no requirement of prior consent, nor of just and equitable sharing.

As recognition of the inconsistencies between CDB and TRIPs grows, some developed countries have been supporting the search for an alternative solution in the scope of the World Intellectual Property Organization (WIPO), as, for those countries, WIPO has enough technical knowledge to offer this solution and the agenda of the Doha Round at the WTO is already too overloaded to accommodate new items. Part of this strategy, known as forum shifting, has the purpose of withdrawing discussions on the theme from the scope of the WTO, exactly where there are enforcement mechanisms by way of the Dispute Settlement Body, and moving the debates to the WIPO, that does not have this 
mechanism - thus, if the rules established by the WIPO are disobeyed, there is no way of demanding or imposing a counter-measure or sanction.

Although developing countries still wish for a solution at the WTO, for the belief that other institutions, including WIPO, would not offer the proper mechanisms for the implementation of the demanded rights, the negotiations with the Council for TRIPs have not been moving further (UNCTAD-ICTSD, 2005).

In 2000, the WIPO General Assembly created the Intergovernmental Committee on Intellectual Property and Genetic Resources, Traditional Knowledge and Folklore (CIG). Presently, the Committee is comprised of 250 representatives of States, indigenous and local communities and several NGOs and intergovernmental organizations, who went on to play a more effective role in the meetings since 2006. However, the CIG negotiations also found deadlocks, in spite of the yearly reunions since 2001.

The Table below seeks to summarize the main characteristics of the treaties and agreements regulating biotechnology internationally.

Table 8 Leading international regimes concerning genetic resources, traditional knowledge and biotechnology

\begin{tabular}{|c|c|c|c|c|c|}
\hline Regime & $\begin{array}{l}\text { Year it } \\
\text { came into } \\
\text { force }\end{array}$ & $\begin{array}{l}\text { Number of } \\
\text { member } \\
\text { countries }\end{array}$ & $\begin{array}{l}\text { Thematic } \\
\text { focus }\end{array}$ & $\begin{array}{l}\text { Enforcement } \\
\text { mechanism }\end{array}$ & $\begin{array}{l}\text { Conflict } \\
\text { with other } \\
\text { agreements or } \\
\text { treaties }\end{array}$ \\
\hline UPOV 1978 & 1978 & 10 & Agriculture & National & CDB \\
\hline UPOV 1991 & 1991 & 68 & Agriculture & National & CDB \\
\hline CDB & 1993 & 193 & Environment & Non-existent & TRIPs, UPOV \\
\hline TRIPs & 1995 & 153 & Commerce & $\begin{array}{l}\text { International } \\
\text { (WTO) }\end{array}$ & CDB, TIRFAA \\
\hline TIRFAA & 2004 & 56 & Agriculture & $\begin{array}{l}\text { Contracts } \\
\text { between } \\
\text { involved } \\
\text { members }\end{array}$ & TRIPs, UPOV \\
\hline
\end{tabular}

Source: own elaboration.

Table 9, as follows, presents the situation of Brazil and other countries regarding the above-mentioned international regimes. 
Table 9 Accession of selected countries in international regimes concerning genetic resources, traditional knowledge and biotechnology

\begin{tabular}{|c|c|c|c|c|c|}
\hline & TRIPs' & UPOV $1978^{2}$ & UPOV $1991^{2}$ & $\mathrm{CDB}^{3}$ & TIRFAA-FAO \\
\hline Brazil & 01 Jan 1995 & 23 Apr 1999 & --- & 28 Feb 1994 & $\begin{array}{l}\text { Signed and ratified } \\
\text { in } 22 \text { May } 2006\end{array}$ \\
\hline China & 11 Dec 2001 & 23 Apr 1999 & --- & 05 Jan 1993 & Did not sign \\
\hline U.S. & 01 Jan 1995 & 08 Nov 1981 & 22 Feb 1999 & 04 Jun 1993 & $\begin{array}{l}\text { Signed in } 01 \\
\text { Nov } 2002\end{array}$ \\
\hline India & 01 Jan 1995 & Not a member & --- & 18 Feb 1994 & $\begin{array}{l}\text { Signed and ratified } \\
\text { in } 10 \text { Jun } 2002\end{array}$ \\
\hline Japan & 01 Jan 1995 & 03 Sep 1982 & 24 Dec 1998 & 28 May 1993 & Did not sign \\
\hline EU & 01 Jan 1995 & 29 Jul 2005 & 29 Jul 2005 & 21 Dec 1993 & $\begin{array}{l}\text { Signed in } 06 \\
\text { Jun } 2002\end{array}$ \\
\hline
\end{tabular}

Source: Own elaboration based in WTO (2008) for TRIPs; UPOV (2011) for UPOV; CBD (2011) for CDB; and FAO (2011) for TIRFAA-FAO. Notes: 1. Date in which the country became a member of the WTO; 2 . Date in which the country became a member of UPOV; 3. Date of ratification (or approval) of CDB, except for the U.S., which present their signature date.

\subsection{The state of affairs in Brazil}

Brazil has been a signatory of the Convention on Biological Diversity since 28 February 1994 (CBD, 2011), and has ratified it. The Convention is, probably, the leading world forum in the definition of legal frameworks concerning biodiversity.

The Convention is structured on three main foundations - conservation of biological diversity, sustainable use of biodiversity and the just and equitable distribution of benefits accrued from the genetic resources - and refers to biodiversity regarding ecosystems, species and genetic resources. Its adoption was justified by the immense biodiversity present in the country, which historically suffers with bio piracy.

In 1995, through the Bill 306, the first discussion in the country on access to genetic resources and benefit sharing (ABS) was launched. However, it was not until 2001, by means of the Provisional Act (Medida Provisória - MP) 2.186-16 that the discussion actually gained a statutory body. The MP defined genetic heritage and demarcated its access in Brazil.

MP 2.186-16 was also responsible for the creation of the Brazilian Council for Genetic Heritage Management (CGEN). Attached to the Ministry of environment the CGEN is responsible for the evaluation of research projects involving access to 
genetic heritage and its associated traditional for scientific research, bio prospection and technological development. ${ }^{263}$

The legislation divided research themes according to three goals: i) scientific research, ii) bio prospection and iii) technological development, both towards access to genetic heritage and to associated traditional knowledge. The institution interested in researching and using assets from Brazilian biodiversity must produce the necessary documentation before the start of the research studies and apply for authorization with the competent organisms, to avoid being subject to the sanctions incident on cases of unauthorized access (SILVA and ESPINDOLA, 2011).

Foreign institutions that intend to access genetic resources must be associated to a national institution. Authorizations are granted exclusively by CGEN when the purpose of the access involves economic potential. If the potential is strictly scientific, authorizations are issued by IBAMA or CNPq (VÉLEZ, 2010).

CGEN deals with most of the applications but it has been given auxiliary branches since 2003. First it was IBAMA (Brazilian Institute for the Environment), which, in that very same year, began authorizing scientific researches. In 2007, the Chico Mendes Institute for the Conservation of Biodiversity (ICMBio) began analyzing collection applications by means of the System of Authorization and Information in Biodiversity (Sisbio).

In September 2011, the accreditation of the National Institute of Historical and Artistic Heritage (IPHAN) was approved for authorizations to scientific researches with access to traditional knowledge associated with genetic resources. And in January 2012, the tests that characterized the new phase of authorizations of access to genetic resources by $\mathrm{CNPq}$ - accredited institution for analysis of applications for scientific researches - were finalized. Scientific research is no longer authorized by CGEN, but rather by IPHAN (with associated traditional knowledge) and IBAMA or $\mathrm{CNPq}$ (without associated traditional knowledge).

The ICMBio authorizes the collection of genetic resources. But, for now, CGEN is the only one that can authorize a application involving both aspects: genetic resource (bio prospection and technological development) and associated traditional knowledge.

One of the demands for the authorization of access for bio prospection is the prior signature of a contract for the use of genetic heritage and benefit sharing, an instrument aimed at ensuring that the benefits accrued from the economic exploration of a product or process are shared among contracting parties, such as the user institution, the land owner (public or private) or representative of the indigenous or traditional community,

263 Besides that Provisional Act, Decrees 3.945/01 and 4.946/03, Article 19 of Act 5.197/67 (Fauna Act) and Decree $96.000 / 88$ are the main national laws that regulate legal access to genetic heritage in Brazil. That legislation is instrumentalized by means of resolutions or of decisions or technical guidelines by the Council for the Genetic Heritage Management (CGEN). 
as well as Brazilian governmental agencies or representatives of the local community. Such contracts come into force only after approval and registration at CGEN. When they do not involve resources from federal public areas, CGEN does not examine whether the benefits are fair or monitors their implementation, and is not obligated to revert those benefits towards the conservation of biodiversity (VÉLEZ, 2010).

There is a great number of resolutions pertaining to the administrative issue and/or of conducting field operations during access to genetic heritage in the country. The table summarizes the chief CGEN norms or those relative to the Council.

\section{CGEN norms or related}

\begin{tabular}{|c|c|c|c|c|}
\hline Type of regulation & $\mathrm{N}^{\circ}$ & Date & Core subject & Remark \\
\hline Law & 6.001 & 19.12 .1973 & Indian Statute & Related legislation \\
\hline Law & 9.279 & 14.05 .1996 & Industrial Property Law & Related legislation \\
\hline Law & 9.456 & 25.04 .1997 & Law for the protection of plant varieties & Related legislation \\
\hline Provisional measure & 2186-16 & 23.08.2001 & Convention on biological diversity & - \\
\hline Decree & 3.945 & 28.09 .2001 & Composition of CGEN and the regulation of the MP & Linked to MP 2186-16 \\
\hline Decree & 4.339 & 22.08 .2002 & National Policy on Biodiversity & Related legislation \\
\hline Decree & 4.946 & 31.12 .2003 & Regulation of the MP & Linked to MP $2186-16$ \\
\hline Deliberation & 101 & 22.03 .2005 & $\begin{array}{l}\text { Pre-analysis of the contracts on the use of the Genetic } \\
\text { Heritage and Benefit Sharing or the Terms of the } \\
\text { Previous Consent }\end{array}$ & $\begin{array}{l}\text { The Council will not } \\
\text { make assessment }\end{array}$ \\
\hline Decree & 5.459 & 07.06 .2005 & Regulation of the MP & Linked to MP 2186-16 \\
\hline Deliberation & 131 & 24.11 .2005 & $\begin{array}{l}\text { Inclusion of new projects in the portfolio of the Special } \\
\text { Access Authorization to the Genetic Heritage }\end{array}$ & . \\
\hline Resolution & 21 & $31.08 .200 \mathrm{G}$ & $\begin{array}{l}\text { Defines Research and Scientific Activities that does not } \\
\text { fit the concept of Access to the Genetic Heritage }\end{array}$ & Linked to MP 2186-16 \\
\hline Deliberation & 203 & 19.07 .2007 & $\begin{array}{l}\text { Delegates jurisdiction to the Executive Secretary for the } \\
\text { Accreditation of Institutions in charge of storing } \\
\text { samples of the genetic heritage }\end{array}$ & Linked to MP $2186-16$ \\
\hline Resolution & 26 & 30.08 .2007 & $\begin{array}{l}\text { Sugarcane varieties is not part of the genetic heritage } \\
\text { of the country }\end{array}$ & Linked to MP 2186-16 \\
\hline Resolution & 29 & 06.12 .2007 & $\begin{array}{l}\text { Describe how to classify fixed and essential oils in the } \\
\text { provisional measure }\end{array}$ & Linked to MP 2186-16 \\
\hline Resolution & 34 & 12.02 .2009 & $\begin{array}{l}\text { Establishes how to confirm the compliance to the } \\
\text { provisional measure for the sake of granting patents } \\
\text { in Brazil }\end{array}$ & Linked to MP 2186-16 \\
\hline Deliberation & 246 & 27.08 .2009 & $\begin{array}{l}\text { Accredit } \mathrm{CNPq} \text { to authorize other institutions to } \\
\text { make certain activities }\end{array}$ & $\begin{array}{l}\text { CNPq does not authorize } \\
\text { access to CTA }\end{array}$ \\
\hline
\end{tabular}

It is worthy of note that many of the resolutions featured on the table above refer to "development of scientific research with no potential economic use". This is a nontrivial identification element that can become subjective, as establishing whether a scientific research is free of economic use potential is no elementary task, especially because field activities may prove promising, contrary to initial expectations. Several institutions find it difficult to identify the benefits that could stem from the commercial development of a product. 
In many cases, the obstacle for the contract is the inability to identify the land owner or even the geographic origin of the genetic resource. In other cases, the collection of those resources has been done in the past, and no precise identification of geographic origin of the genetic resource remained. In cases in which bio prospection involves genetic resources collected in different places, the need for the elaboration of different contracts adds difficulty to the process.

\section{ACHEFLAN CASE - BALEEIRA HERB}

A well-known case involved the Ache laboratory, regarding the production of anti-inflammatory medication "Acheflan", using the extract of the erva-baleeira (baleeira herb), a plant traditionally used by natives in the coast of the State of São Paulo to treat contusions and inflammatory processes. One of the laboratory directors, residing in the coast of São Paulo, had the habit of playing soccer with members of the native community in the region and used the "garrafadas" (bottled ointments) to heal sports lesions. As reported, this director had the idea of transforming the local native knowledge in phytomedication. Researches were conducted from 1998 to 2004 to isolate the active principles of erva baleeira and, with the approval of ANVISA, the patent application was filed at the Patent Office in 2002. CGEN saw fit to examine the case because of the access to traditional knowledge involved. The Ache laboratory proceeded to file a court injunction to guarantee that the product would be launched without CGEN interference and succeeded. The product was launched and became a market leader (Mariot, 2010).

Such difficulties cast doubts over the operational logic of the existing legislation. The bridging of the benefits to the land owner generates elevated transaction costs, without guarantees that the benefits will be reverted to the conservation of biodiversity.

According to Benjamin Gilbert, senior technologist of Farmanguinhos/FIOCRUZ,

the CGEN set of 50 regulations involving prospection, access, transportation and other industrial operations of the transformation process of a medicinal plant into a phytomedication, if not strictly follow, results in weighty fines. They demand, for instance, a contract with the owner of the land of collection of the plant and another with a local community identified as owner of the associated knowledge that validates the plant as medicinal. Transporting the plant also requires authorization. (Abifina, 2011) (translated from the original) 
Thus, the Brazilian legislation would be achieving the opposite result it desired, punishing national researchers without preventing smuggling or bio piracy by foreigners. As mentioned, foreign institutions that intend to access genetic resources must be associated to a national institution. For some field experts, the present legislation ends up working as an incentive for companies to disregard the bureaucratic rules - which ends up encouraging bio piracy.

As proposed, the Brazilian accession to the Nagoya Protocol, which enables a foreigner to access a resource from a given country as an individual, without being associated to institutions, is under examination. Another point deals with the need to refrain from being prejudiced against the foreigner in favor of national researchers. Nonetheless, several experts defend the de-bureaucratization of the Brazilian regulatory framework with the aim of facilitating the work of national researchers, maintaining, however, the demand for partnerships with local institutions for foreigners.

The incorporation of CBD in the country also had an impact on Brazilian patenting. Regarding the access to the components sample of the Natural Genetic Heritage, determined by the Article 31 of MP 2.186-16, the Patent Office, from the CGEN Resolution 23, of 10 November 2006, launched Resolution 134/2006, in force since 2 January 2007, which institutes in its Art. 2 that the applicant must declare in a specific field of the patent application form or PCT form - entry in the national phase, if the object of patent application has been granted or not, as a result of the access to a component sample of the national genetic heritage, in case it took place after 30 June 2000. If affirmative, the authorization number and date must be informed, as well as the origin of the genetic material and the traditional knowledge, when applicable.

This measure resulted in several disputes and incompatibilities between the attempt to preserve Brazilian biodiversity and its use towards research and patenting in the country. The procedures for obtaining access authorization were considered complicated, worsened by the fact that the contract of benefit sharing had to be signed before the access, in case of potential commercial use.

As a result, few access authorizations were granted, and several patent applications are pending at the Patent Office, given the legal uncertainty involved in the whole process. It was not by chance that there was a noticeable increasing in the participation of the Judicial Branch in decisions regarding the patenting of biotechnologies and/or the access to local genetic heritage, whether as an entity demanded by directly interested agents in specific situations or in the as direct intervening actor, of which federal courts specializing in patent issues are practical examples.

Adjustments to this procedure rapidly became necessary. Several institutions were prevented from filing their patents for activities initiated without proper authorization. 
In response, the Resolutions 34 of CGEN and 207 of the Patent Office were created in 2009, determining that patent applications involving genetic resources and traditional knowledge now had to be accompanied by an additional form featuring the number of the corresponding access authorization or a declaration of non-use of resources obtained in areas in national jurisdiction.

The main adjustment concerned the time available to produce the access authorization to the Patent Office, given the large time span between patent filings and their granting - presently of about 8 to 10 years. The submittal of this form is now mandatory only in the technical examination stage, after the preliminary formal examination. If the form is not handed down within the required deadline (60 days), the filing is suspended. After those resolutions, the onus is shared between applicant and patent examiner.

It is imperative to regulate the use of genetic resources and traditional knowledge, including prior consent and the just and equitable sharing of benefits in order to, on one hand, facilitate the access of national companies that wish to develop products based on national biodiversity and/or traditional knowledge and, on the other had, establish a manner of just and equitable distribution of the economic result accrued from the use of those resources and knowledge. Simplifying the treatment of the subject is essential for its success as public policy and as regulation, both nationally and internationally, as well as for the sustainability of national biodiversity and autochthonous communities.

The Ministry of Environment created a norm in April 2011 to lessen the difficulties identified in the present scenario with the aim of enabling the access to genetic resources for research, prospection and technological development by CGEN. Until then, the legislation demanded that the authorization be applicationed to CGEN beforehand.

Not only there was a great quantity of accumulated processes, but the cases in which there was access to biodiversity resources without prior authorization were piling up without a possible solution. Ever since then, the cases in which the authorization was applicationed after the access became eligible for regularization ${ }^{264}$ (AGROSOFT, 2011).

According to the report of the $19^{\text {th }}$ Meeting of the National Biotechnology Committee, by the workgroup comprised of members of MDIC, MMA, the Patent Office and CGEN, among others, a proposal for a Provisional Act aimed at accelerating the access procedure was elaborated, focusing on the research undertaken by citizens and Brazilian

264 Due to changes in the Council for the Genetic Heritage Management (CGEN), Brazilian cosmetic producer Natura obtained consent for two applications concerning economic exploration of plants. Some time earlier the company had received fines which amounted to BRL 21 million because of the use of unauthorized genetic resources. 
institutions; on regularizing the issues of distribution of benefits accrued by the use of associated knowledge; and restricting the access of international research institutions.

\subsection{Recommendations}

a) To Congress:

Undertake an independent study in order to map out the Brazilian scenario concerning the use of genetic resources and traditional knowledge and its economic, social and legal implications for Brazil, to propose, with an empirical basis, recommendations and possible legislative proposals for a more balanced treatment of the issue in Brazil. 


\section{PRIZE SYSTEM AS AN ALTERNATIVE TO PROMOTE INNOVATION}

In addition to the traditional system of patent and related rights, there are recent proposals for the creation of a prize system, as well as an open model for research, development and innovation. Those proposals are briefly discussed as follows.

\subsection{Open research, development and innovation model}

Since 2003, the World Health Organization (WHO) has sheltered important initiatives that aim at studying the relationships between public health, technological innovation and intellectual property rights. Among the leading frameworks are the following three groups and commissions: the Commission on Intellectual Property Rights, Innovation and Public Health - CIPIH; ${ }^{265}$ the Intergovernmental Working Group on Public Health, Innovation and Intellectual Property - IGWG; ${ }^{266}$ the Expert Working Group on R\&D financing and coordination - EWG ${ }^{267}$ and the Consultative Expert Working Group on Research and Development: Financing and Coordination - CEWG. ${ }^{268}$

One of the main pillars of this rich process is Resolution WHA 61.21, known as Global strategy and plan of action on public health, innovation and intellectual property, that is the result of IGWG discussions and was approved in 2008 during the World Health Assembly, which is the highest decision-making body in the WHO.

The above-mentioned Resolution recognizes a complex scenario set up after the advent of the TRIPs Agreement of the World Trade Organization, and the need for an urgent solution by way of new incentives regarding a series of diseases that affect developing countries. It is an instrument of great political relevance, reflecting a long discussion about scientific research, innovation and the access to medicines. Historically, Brazil and the Union of South American Nations (Unasul), ${ }^{269}$ comprised of the 12 countries of South America, have been on the forefront of the WHO's discussions and the support to the Global Strategy was emphasized in President Dilma Rousseff's speech to the General Assembly of the United Nations in 2011.

The CEWG was constituted upon demand of the member states to tackle two great items of the Global Strategy: item 2 (promotion of research and development) and item

265 The group report can be accessed at http://www.who.int/intellectualproperty/en/.

266 Information about the group's work is available at http://www.who.int/phi/igwg/en/index.html.

267 Informations about the group and its report are available at http://www.who.int/phi/ewg/en/index.html.

268 The final group report is available at http://www.who.int/phi/cewg_report/en/index.html.

269 About Unasul, see http://www.itamaraty.gov.br/temas/america-do-sul-e-integracao-regional/unasul. 
7 (promotion of sustainable financial mechanisms). At the World Health Assembly in May 2012, the countries considered the CEWG report and approved the Resolution WHA 65.22, which allowed discussions about the report's recommendations to be maintained and the beginning of further, in-depth discussion about the two main themes: the financing of research about diseases that affect neglected populations and the coordination of researches, including through the monitoring of investment flow.

\section{INNOVATION CRISIS IN THE WORLD PHARMACEUTICAL INDUSTRY}

The innovation crisis in the world pharmaceutical industry is a highly impacting element of discussions. According to experts Light and Lexchin (2012), many of the new medicines launched over the last few years consist of slight alterations of existing products. According to the authors: "Out of 218 drugs approved by the FDA from 1978 to 1989, only 34 (15.6\%) were judged as important therapeutic gains. Covering a roughly similar time period (1974-94), the industry's Barral report on all internationally marketed new drugs concluded that only $11 \%$ were therapeutically and pharmacologically innovative. Since the mid-1990s, independent reviews have also concluded that about $85-90 \%$ of all new drugs provide few or no clinical advantages for patients."

The multinational pharmaceutical industry has been investing in research of medicines that are but new uses for known compounds, among other forms that are not necessarily innovative, among which the legal artifice of patent term extension, which ends up making a negative impact on the access to medicines, on national development and on innovation in the pharmaceutical field, as described in Chapters 4, 6, 7 and 8 of this Report.

\section{MARKET LOGICS AND NEGLECTED DISEASES}

Research and production in the pharmaceutical industry do not prove satisfactory regarding the development of technologies and health solutions of interest to neglected populations. As explained by Gadelha (2009), "in the articulation of the innovation dynamics with society, it can be said that the virtuous circle of investment in R\&D and marketing, innovation, profitability and growth has a perverse dimension in which the market logic detaches itself from health needs, especially in those countries and populations with less buying power and high incidence of neglected diseases."

The present system of promoting innovation based on patents has been proven inefficient for several countries, in two dimensions: innovation and access. As the present system is based on the sale of products at elevated prices with a view to the right to exclusivity, that 
hampers competition, guaranteed by patents or related rights, this system has allocated resources guided by market interests and not necessarily health needs.

That is why, among other motives, the present patent system has been inefficient in tackling several health issues in countries with populations with less purchasing power. On the other hand, when there are existing patents for medical products, the elevated prices have been working as a substantial barrier to access to medicines, which, in many cases, ends up excluding millions of people, in several countries, from the access to those medicines that are essential to health. Starting with this diagnosis, there has been a growing effort, presently led by the WHO, to identify alternatives that may be employed in directing research, development and innovation investments towards the real health needs, especially in less technologically advanced countries, and making the final medicines available at affordable prices.

Regarding research costs, in spite of the elevated figures publicized by the pharmaceutical industry and by some academics (Dimasi et al, 2003; Dimasi et al; 2007), data from the United States indicate that basic research, which yields results that are used by pharmaceutical companies for highly profitable commercial activities, is strongly subsidized by public coffers. According to Light and Lexchin (2012), over $80 \%$ of all basic research investment towards the development of new medicines and new vaccines comes from public sources.

\section{MARKETING EXPENDITURE ARE GREATER THAN R\&D}

A considerable part of the final price of medicines corresponds to marketing expenses, which are in fact greater than expenses with research and development (R\&D). Dr. Marcia Angell (2008), from Harvard University, calculates that marketing expenses increase pharmaceutical products' prices by about $30 \%$.

The argument of research cost recovery reflected in the prices of medicines frequently leads to unsustainable situations. This practice comes into deep conflict with the ability of less favored countries to tackle sums that are incompatible with their economic reality (Moon, Bermudez, t'Hoen, 2012). As explained by Fiani et al (2009), "excessively expensive medication can derail programs aimed at making essential medication available, both when those programs use public resources, which are scarce in least developed countries, and when the patients themselves must shoulder the costs, a situation that is frequent in poorer countries. The latter option is also grievous, as income per capita is lower in those countries."(translated from the original) Each year, millions of people die or deal with profound suffering from diseases that can be treated but the product is not available or can only be purchased at prohibitive prices. 
Högberg, Heddini and Cars (2010) point out to additional difficulties. The problem of antibiotic resistance is well reported in literature, and even in the press, resulting in enormous challenges for public health and international organizations. The health systems are facing the alarming increase in resistant bacteria to available drugs, as well as the decline of research and development investments, and the lack of interest of the pharmaceutical industry in this line of work. As admitted Martin Mackay, of the AstraZeneca research team, in interview to The Economist, in May 2012, "It is not our hottest area in terms of commercial return".

The pharmaceutical industry neglects areas with less than spectacular financial feedback. Faced with this preoccupying and unbalanced picture, the governments have the moral obligation of providing solutions to alleviate the suffering of populations as well as the legal duty to implement public policies for the promotion of the right to health. It is worth remembering that the right to health is part of the Constitutions of several countries (CORREA, 2012). Among developing countries, Brazil is known for having guaranteed the universal right to health and created the foundations for the formation of the National Health System, ruled by the ethical principles of humanism and solidarity (CARVALHEIRO, 1999).

From the standpoint of technological and economic development, the sale of medicines through mere import of the product or active principle makes those countries even more vulnerable, as, without providing access to fundamental technologies for their populations, they are at the mercy of frequently abusive prices and eventual shortages. In Brazil, we have seen over the last few years alarming episodes of shortage and fractioning of medicines used in the treatment of AIDS, for instance, that are part of one of the best structured health programs in the country, which is in fact a world model (GTPI, 2011). Those episodes could be minimized if the supply of medicines did not depend on a sole manufacturer, which is what happens when there is patent protection of the medicine.

It is not just about expanding resources destined to research activities, but also allocating them to tackle real needs regarding health and the development of the country and applying them to truly innovative models that are not exclusionary to maximize shared research knowledge and expand access.

The need for the implementation of mechanisms to disconnect research and development costs from the prices of medicines becomes quite clear. Over the last few years, this discussion was taken further at the World Trade Organization, in civil society as well as several international forums.

In that regard, public interest organizations of civil society in different countries, including the Doctors Without Borders and Oxfam, have sent a letter to WTO member 
countries proposing the creation of a global mechanism for the coordination and financing of research and development activities directed towards tackling the real health needs of the population. ${ }^{270}$

An article organized by Rottingen et al (2012) points out that one of the chief concerns is how to tackle the issue of under-financing of researches that aim at generating health solutions for underprivileged populations, given that market incentives and stimulus through the patent system appear to be insufficient and not very efficient to attend to those needs.

Welfare resources and other diverse initiatives (Medicines for Malaria Venture, among others $)^{271}$ established themselves over the last few years with the intention of facilitating access to medicines and seeking out new medicines of interest for developing countries. However, the present scenario is still lacking sustainable and sufficient solutions that guarantee the access to health products and bring scientific and technological ability to those countries. CEWG analyzed a wide-ranging set of proposals stemming from all sectors of society and from different countries, including Brazil, and produced an analysis by means of a report.

It is worth mentioning the example of DNDi - Drugs for Neglected Diseases initiative, which is also active in Brazil. DNDi was created in 2003 as a response to market and public policy flaws regarding the lack of innovation in medicines for the treatment of neglected diseases. Working in collaboration with public and private partners all over the world, DNDi developed six new medicines already available for neglected patients and counts on several candidates to new medicine in process of development; including two for the sleeping sickness and one for barber bug fever, in the phase of clinical studies. Up until this moment, DNDi reckons that the development cost will varies from 10 to 40 million Euro for improved treatments and from 100 to 150 million Euro for a new molecular entity (DNDi, 2012). The experience of DNDi and of other similar initiatives reveals that collaborative research models based in mechanisms of open innovation can lead to reduction of costs in the development of new drugs as well as facilitate the development of medicines that truly meet the health demands of populations with low purchasing power.

270 Available at http://www.essentialdrugs.org/edrug/archive/201211/msg00042.php.

271 More information about the public-private partnership available at http://www.mmv.org/. 


\section{CREATION OF AN OPEN, GLOBAL PUBLIC FUND}

The leading recommendations of the CEWG report seek to offer solutions of structuring character for financing and for research and development coordination. The CEWG report recommends regulations to promote public action in the generation of knowledge that are fundamentally deemed global public assets (Stiglitz, 1999). The CEWG report proposes a governmental contribution of $0,01 \%$ of the GDP for every country, with the aim of injecting new and unpredictable resources towards the well being of the populations and doubling the present investments. The issue is not just creating resources, but also explore them the best way possible. Thus, the intention is that these investments are applied to researches with free, open for sharing, results, feeding innovation and local production processes in all countries.

It is a paradigmatic change that results in a democratization of costs and benefits. Free of aiming at profits disconnected from social well being, the research will be able to prosper in a fertile environment of cooperation and technology transfer that is conducive to find solutions for a number of diseases that fall out of the interests of the multinational pharmaceutical industry, since they do not deliver the same financial feedback as the same industry blockbusters. The model proposed in the CEWG report does not replace or exclude the model of incentives via patent rights. It is a supplementary model and it is compatible with the dominant innovation model which seems to work relatively better in high income countries.

For Brazil, strengthening the public presence in health innovation by means of investments fixed as GDP percentage will certainly bring several advantages to the consolidation of the Industrial Health Complex and the National Health System, delving further in the notion of welfare State. The implementation of a free and open research and development model is completely compatible with the reigning model, according to which part of the knowledge is temporarily protected by the patent regime and correlated.

The sustainability of the proposition of minimum public financing is founded in another recommendation: the binding Global Convention on Research and Development. The adoption of a binding convention is not something new in the scope of global health. The World Health Organization recently hosted the Framework Convention on Tobacco Control, with encouraging results in many countries. After the phase of analysis of recommendations of the CEWG report, it is expected that member states open up negotiations for a very clear commitment: a multilateral binding instrument.

The creation of a minimum baseline of public global investments for research on neglected populations' interests and an improvement in the global coordination of research and development have some specific characteristics: (i) the predominating model in research and development and the pro-market orientation do not meet the 
health needs of neglected populations; (ii) it is not enough to strengthen innovation; it is necessary to guarantee the access to relevant products by severing the connection between research costs and product price; (iii) improving the monitoring of costs what is spent and how it is spent globally and defining research priorities having local needs in mind, with zeal and transparency, and with the active participation of interested countries (and not financial feedback priorities) will elevate the efficacy of the research on human health; and (iv) voluntary financing is welcome, but insufficient for the establishment of a free and open research and development model that values the free sharing of essential technological knowledge (Correa, 2012).

\subsection{Prize system}

In addition to the proposal of public financing from a GDP percentage, a relevant path to incentives in health innovation is the creation of prizes.

Nowadays, the global pharmaceutical scenario relies on incentives that involve market exclusivity (by means of patents and related rights) and elevated prices, creating important barriers for access, whether by direct purchase from the patient or via health insurance and public health systems.

Besides, market exclusivity leads to the application of huge sums in product marketing, which elevates its final price even further. Faced with the scarcity of researches for tropical diseases and other neglected diseases that yield low or uncertain financial return in comparison to top-selling medicines, it is necessary to think of alternative incentives (not via patents and related rights) to stimulate innovation and avoid exclusivity conditions that harm public health.

A prize system is a concrete alternative for the optimization and improvement of the innovation system. From Shavell and Tanguy's (2001) standpoint, "[r] eward systems (...) appear on reflection to hold promise as alternatives to our system of intellectual property rights, because there is no necessity to marry the incentive to innovate to conferral of monopoly power in innovations."

Prizes have been proving another alternative to reward research and innovation and to keep the final price within a balanced range. Prizes can be used to stimulate research with a previously defined priority (by the Ministry of Health, for instance) and encouraging work in truly needy areas. The implementation of funds can allow the government to have more control over what to develop, how much to spend in each research phase, how to use research results and how to distribute the products (medicines, vaccines, diagnosis kits, among others). 
In the prize system, research data can be freely used in other researches without the risk of disobeying clauses in technology contracts based in an exclusivity regime. In that sense, Stiglitz (2006) emphasizes that "the medical prize fund would ensure that we make the best possible use of whatever knowledge we acquire".

Competition would be stimulates, cooperation would increase and the government would tend to save on resources. There would be no expenses with legal battles because of patent or exclusivity contracts issues. On the other hand, the offer of prizes has to be very selective and precise. In areas in which the prize is not offered, the system of incentives via patents and related rights, if properly balances, can work very well.

In short, the implementation of stable public resources committed to a research and production model focused on free knowledge sharing, as well as a prize system, can help take less favored countries to another development level. The benefits can be many: scientific and technological training, local production, employment and income, formulation of own priorities, access to essential products and social justice.

\subsection{Recommendations}

a) To the Executive Branch:

\section{a.1) to the Executive Branch:}

a.1.1) elaborate a draft bill creating a minimum contribution of $0.01 \%$ of the Gross Domestic Product for the creation of a research and development fund for the area of neglected diseases and other national interest public health matters. Evaluate the convenience of using as a source of revenue, besides the GDP, part of the taxes from tobacco and alcoholic beverages. The research results stemming from this financial contribution would be placed under public domain or a mandatory open access scheme. Research must be conducted by Brazilian institutions or companies based on a definition of priorities coordinated by the Ministries of Health, and Science, Technology and Innovation; and

a.1.2) elaborate a draft bill for the creation of the Brazilian Health Innovation Prize, with the goal of encouraging health research under a non-exclusivity regime (open access scheme) based on the definition of priorities coordinated by the Ministries of Health, and of Science, Technology and Innovation. 


\section{a.2) to the Ministry of Foreign Affairs:}

Negotiate along with the World Health Organization and/or the World Trade Organization and/or the World Intellectual Property Organization the possibility of creating an international instrument for the creation and implementation of a global fund for the financing and incentive of health research under an open access regime. 


\section{SOFTWARE PATENTS}

In the beginning of 2012, IPNPI conducted a public consultation, for 60 days, about a proposal of a guideline about "procedures for the examinations of patent applications involving inventions implemented by computer software". 272

According to a study by jurists and computer experts from the University of São Paulo and the Getúlio Vargas Foundation, the European Commission

published a directive proposal for 2002 according to which a computer software would be patentable [...]. After five years of a an extensive indepth public debate, the proposal was voted and rejected by the European Parliament, the highest legislative sphere in the community scope. One of the chief bases for rejection was the risk of hindering software development in Europe [...]. ${ }^{273}$ (translated from the original)

Ten years after Europe extensively discussed the subject, in a public and inclusive manner, and for 5 years, the Patent Office conducts a public consultation for 60 days to discuss the same subject - which was massively rejected by the European Parliament due to the risks that such patents could offer to the European technology market.

There is no discussion about guidelines for examination of software patents without an extensive and inclusive debate about the risks and opportunities of such patenting, as well as independent studies about the eventual positive and negative impacts that the patents of inventions implemented through computer software can make in Brazil.

According to the World Trade Organization, the regime of intellectual protection of computer software's is the same conferred to literary works by the copyright law in force, according to Article 10.1 of the TRIPs Agreement. Software, therefore, is already protected by the Copyright Act (Act no. 9.610/98) and by specific legislation in Brazil (Act no. 9.609/98).

Software is a purely abstract conception, a mathematical method, and is not subject to industrial application. In other words, software is an idea, a mathematical formula. And ideas or purely abstract conceptions may not and cannot be patented, according to Article 10 of the Patent Act (Act no. 9.279/96).

Whether we consider software in itself or an invention implemented by software, which changes nothing about the public technology policy in practice. If one admits that a (supposed) invention may be implemented by computer software, the patent would

272 Public Consultation no. 1, published in the Official Gazette in 16 March 2012.

273 See Eros Roberto Grau, et. al., "Por um Brasil Inovador: Estudo da FGV e USP contra a Concessão de Patentes para Programas de Computador no Brasil", p. 6. 
be granted for the ensemble, including the computer software. In practice, the patent would be granted to the software.

So much so that many patent grants by Brazilian Patent Office were based on applications that, in order to avoid the legal impediment regarding computer software in itself, characterized computer software as industrial processes or methods, as demonstrated by the following examples:

\begin{tabular}{|c|c|c|c|}
\hline Patent number & Patent object & $\begin{array}{l}\text { Date of } \\
\text { granting }\end{array}$ & Holder \\
\hline PI 8606363-4 & $\begin{array}{l}\text { Method and equipment for the execution } \\
\text { of several applications concomitantly in a } \\
\text { processing system }\end{array}$ & 05 Mar 1994 & IBM (U.S.) \\
\hline PI 8806690-9 & Process for the development of software & 27 May 1997 & $\begin{array}{l}\text { Hitachi, Ltd. } \\
\text { (Japan) }\end{array}$ \\
\hline PI 8602558-9 & $\begin{array}{l}\text { Method for compression and } \\
\text { decompression of a data set }\end{array}$ & 06 Sep 1994 & IBM (U.S.) \\
\hline PI 9006933-1 & $\begin{array}{l}\text { Process and a set to effect an } \\
\text { approximate arithmetic division }\end{array}$ & 06 Oct 1998 & $\begin{array}{l}\text { T.L.M. Ericson } \\
\text { (Sweden) }\end{array}$ \\
\hline PI 9303047-9 & $\begin{array}{l}\text { Device and method to produce a } \\
\text { tridimensional object and method to } \\
\text { produce an object using a computer } \\
\text { database }\end{array}$ & 08 Jun 1999 & $\begin{array}{l}\text { Texas } \\
\text { Instruments, } \\
\text { Inc. (U.S.) }\end{array}$ \\
\hline
\end{tabular}

It can be observed that, even before the present Patent Act, which came into force in May 1997, the Brazilian Patent Office already granted software patents, provided they were described as industrial processes or methods.

This trend still goes on at the Patent Office, as exemplified in the following table:

\begin{tabular}{|llll} 
Patent number & Patent object & $\begin{array}{l}\text { granting } \\
\text { date }\end{array}$ & Holder \\
PI 9105295-5 & $\begin{array}{l}\text { Process to effect image processing and } \\
\text { device to effect image processing }\end{array}$ & 31 Oct 2000 & $\begin{array}{l}\text { Xerox } \\
\text { Corporation } \\
\text { (U.S.) }\end{array}$ \\
& $\begin{array}{l}\text { Multimedia computer system and } \\
\text { method to control the operation of a } \\
\text { multimedia tasks computer system }\end{array}$ & 08 Mar 2000 & Lenovo \\
& (Singapore)
\end{tabular}




\begin{tabular}{|c|c|c|c|}
\hline Patent number & Patent object & $\begin{array}{l}\text { granting } \\
\text { date }\end{array}$ & Holder \\
\hline PI 9407646-4 & $\begin{array}{l}\text { Device to optimize the relationship } \\
\text { between expenses and growth rate } \\
\text { for live creatures; process to operate } \\
\text { a computer; process to determine the } \\
\text { use of nutrient efficacy in a population; } \\
\text { and computer system to determine the } \\
\text { efficacy of nutrient use in a population } \\
\text { based on the theoretical average gain } \\
\text { for a time period for the population }\end{array}$ & 15 Feb 2005 & $\begin{array}{l}\text { American } \\
\text { Institute of } \\
\text { Nutrition and } \\
\text { Management } \\
\text { (U.S.) }\end{array}$ \\
\hline PI 9507311- 6 & $\begin{array}{l}\text { Interactively remote controlled system } \\
\text { and method of data exhibition for a } \\
\text { television programming guide on a } \\
\text { display screen }\end{array}$ & 15 Apr 2003 & $\begin{array}{l}\text { Prevue } \\
\text { International, } \\
\text { Inc. (U.S.) }\end{array}$ \\
\hline PI 9612772-4 & $\begin{array}{l}\text { Method and software device against } \\
\text { digital forgery }\end{array}$ & 12 Nov 2002 & $\begin{array}{l}\text { Graphic } \\
\text { Security } \\
\text { Systems } \\
\text { Corporation } \\
\text { (U.S.) }\end{array}$ \\
\hline PI 9611056-2 & $\begin{array}{l}\text { Method, system and computer program } \\
\text { to compress an original image; method, } \\
\text { system and computer program to } \\
\text { compress a data chain; and method, } \\
\text { system and computer program to } \\
\text { compress data }\end{array}$ & 25 Apr 2006 & $\begin{array}{l}\text { America } \\
\text { Online Inc. } \\
\text { (U.S.) }\end{array}$ \\
\hline PI 9700082-5 & $\begin{array}{l}\text { method and control system to control } \\
\text { change in an automated set system } \\
\text { for vehicle starting and product of a } \\
\text { computer program }\end{array}$ & 16 Apr 2002 & $\begin{array}{l}\text { Eaton } \\
\text { Corporation } \\
\text { (United } \\
\text { Kingdom) }\end{array}$ \\
\hline PI 9802354- 3 & $\begin{array}{l}\text { Method to prevent unauthorized } \\
\text { inspection of the source code of a } \\
\text { computer program }\end{array}$ & 01 Dec 2009 & $\begin{array}{l}\text { Dell U.S., L.P. } \\
\text { (U.S.) }\end{array}$ \\
\hline PI 9813922-3 & $\begin{array}{l}\text { Schematic generator and product of } \\
\text { a computer program for use with a } \\
\text { network of process control and process } \\
\text { of generation of a scheme in a network } \\
\text { of process control }\end{array}$ & 09 Feb 2010 & $\begin{array}{l}\text { Dell Fisher } \\
\text { Controls } \\
\text { International } \\
\text { LLC (U.S.) }\end{array}$ \\
\hline PI 9816281-0 & $\begin{array}{l}\text { System and method of equipment } \\
\text { management and means of registration } \\
\text { readable in computer with steps of the } \\
\text { method of equipment management } \\
\text { stored in it }\end{array}$ & 27 Dec 2011 & $\begin{array}{l}\text { Dell TLV } \\
\text { Company, Ltd } \\
\text { (Japan) }\end{array}$ \\
\hline
\end{tabular}

In practice, software patents are being granted, in clear confrontation of legislation and national interest - and, more than that, without any type of debate on the subject, whether with society, with the business sector, or with academic field experts, not even with the Ministries that are members of the Inter-ministerial Group on Intellectual Property (GIPI). 
The above-mentioned technical study by USP and FGV is categorical in explaining that

[the] Brazilian Patent Office proposal would have the mere goal of "helping with the technical examination of patent applications involving inventions implemented by computer programs"; however, in doing so, they admit, through a non-statutory diploma (resolution of the ministerial body), that the software is subject to the patent regime, which is the opposite of the regime adopted by the country's legislation. The contents of the "Guidelines" are made even more surprising by conferring extensive patentability to computer software encompassing technical effects both in the physical and virtual worlds, whether the software is embodied in a machine or not, and including computing processes such as optimization of text processors or benefits in the user interface. All that sits on the interpretation that the "software in itself" (which cannot be an invention by force of Art. 10, item $\mathrm{V}$ of the Industrial Property Act no. 9.279/96) would consist of just the software without a technical effect; all the others with technical application or utility being patentable. But practical usefulness is one of the dimensions of any software, which gives the the Patent Office Guidelines a potential impact in terms of software patentability even bigger than the U.S.'s, making space for any software description to have invention status and be eligible for patenting. ${ }^{274}$

The permission of software patenting in Brazil casts national software developing businesses into legal uncertainty, as each line of code developed in Brazil becomes subject to questioning over its origin and ownership.

Any citizen or company, large or small, users of software, would be potential targets of legal battles, in case the computer software in use violates third-party patents. Foreseeing or avoiding patent infringement is nearly impossible, especially in cases involving closed source-codes for the computer software that are secret and private to the supplier.

The most grievous issue is that software patents block competition and innovation in the information technology sector, since, in order to make competing software's, different businesses work towards tackling the same issues and, frequently, come up with similar or equal solutions. And, as the patent bestows rights of functionality, it does not matter whether a software developed by a competing business has been done entirely independently: infringement happens anyhow, if the functionalities are identical or very similar - even if the software programs were developed independently.

Innovation in the software industry, for its specific features, works in a sequential and cumulative manner. Computer software programs are not static reactions: they 
suffer constant adaptations and improvements. ${ }^{275}$ This sequential innovation "builds up cumulatively over other inventions, unlike the airtight innovation limited to other products in many other areas". ${ }^{276}$ At the same time, and for the same reason, computer software programs are frequently written based on concepts and subroutines of other pre-existing software, including usability and accessibility for persons with disabilities. ${ }^{277}$ That is the nature of the construction of computer program algorithms. However, the institute of patents is not appropriate for the software sector, at the risk of stifling innovation in the information technology field.

In the words of the respected Commission for Intellectual Property Rights of the Government of the United States, "the process of innovation may be cumulative, and iterative, drawing on a range of prior inventions invented independently, and feeding into further independent research processes by others. [...]The development of software is very much a case of building incrementally on what exists already." And the abovementioned Commission closes with the following recommendation: "[e]xclude from patentability computer programs and business methods". ${ }^{278}$

Professors at Harvard and Brandeis Josh Lerner and Adam Jaffe show that "the cumulative nature of innovation in several important industries puts multiple innovative firms in constant conflict with each other. The patent system seems increasingly to be a source of uncertainty and costs (...)." 279

The president of Financing Agency for Studies and Projects (Financiadora de Estudos e Projetos - Finep) and USP Professor Glauco Arbix expresses concerns with the improper use of the patent system by means of reckless lawsuits that would generate legal uncertainty and risk "inhibiting the creation of novelty. Thus, it shrinks the realm of user choices and poses more obstacles for bridging the gap that separates countries such as ours from the production of more advanced technologies." 280 That is exactly the risk posed by the granting of patents for a cumulative and sequential technology such as the software.

275 See testimony by the deputy chief attorney of Microsof before the Federal Trade Commission of the United States, The Evolving IP Market Place - Aligning Patent Notice and Remedies with Competition, 2011, pp. 44-45.

276 See Eros Roberto Grau, et. al., op. cit., p. 19.

277 See Julie Cohen e Mark Lemley, Patent scope and innovation in the software industry, California Law Review, Vol. 89, n. 1, Jan., 2001, p. 41.

278 See Reino Unido, Comissão para Direitos de Propriedade Intelectual (CIPR), "Relatório da Comissão para Direitos de Propriedade Intelectual - Integrando Direitos de Propriedade Intelectual e Política de Desenvolvimento", Londres, 2002, p. 112.

279 See Adam B. JAFFE e Josh LERNER, Innovation and Its Discontents - How our Broken Patent System is Endangering Innovation and Progress, and What to Do About it, Princeton, 2004, p. 76.

280 ARBIX, Glauco. Uma guerra global, um jogo de muitos bilhões in Valor. 11, 12, 13 and 14 October 2012, p. 11. 


\section{SMARTPHONE INDUSTRY SPENDS OVER US\$ 20 BILLION WITH LAWSUITS ON SOFTWARE PATENTS}

A Stanford University study showed that the smartphone sector spent, over the last two years, US $\$ 20$ billion in patent litigations and patent purchases; a sum equivalent to eight NASA Curiosity missions to Mars. ${ }^{281}$

The following graph illustrates "who is suing who" in the smartphone sector, for matters regarding software patents: ${ }^{282}$

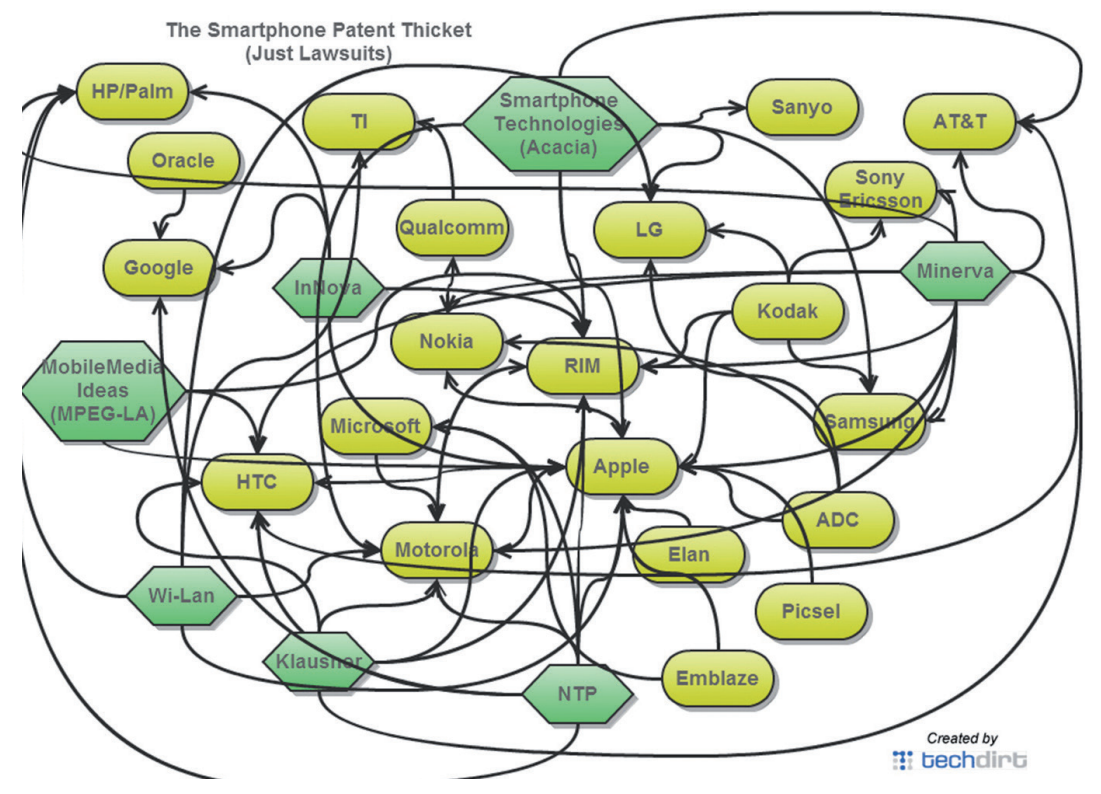

This patent cluster rounds up what is known as patent thickets, or a buildup of patents with overlapping ranges. This cluster of overlapping patents, if involving different patent holders, is what is conventionally known as gridlock, meaning a kind of jamming of several patents with different patent holders that bestow rights upon complementary technologies such as smartphone or even software technology.

Those patent thickets end up encouraging the use of the patent system for defense or strategic purposes, instead of being used to generate innovation and better products for society. As to the Hargreaves Report by the Government of the United Kingdom warns,

Strategic patenting behaviour has been further encouraged in some markets by an increase in the number of weak, low value patents. High transaction

281 See DUHIGG, Charles e LOHR, Steve. The Patent, Used as a Sword in New York Times. 7 de outubro de 2012. 282 See MASNIK, Mike. Why the Answer to Smartphone Patent Thickets is not a Patent Pool in Techdirt. 29 de outubro de 2010. 
costs, and the need to overcome strategic behaviours, cause firms to under invest in the commercialisation of downstream technologies resulting in a form of gridlock, sometimes referred to as a "tragedy of the anticommons" in which firms underuse new knowledge because too many owners can block each other. ${ }^{283}$

This behavior, evidently, is highly detrimental to society and contrary to the patent clause of the Constitution.

\section{APPLE AND GOOGLE SPEND MORE WITH SOFTWARE PATENT LAWSUITS THAT WITH R\&D}

In 2011, lawsuit expenses at Apple and Google, as well as patent purchase expenses, exceeded the companies' investments in research and development of new products. 284

In the U.S., from 1995 to 2011, software patent holders won less than $25 \%$ of court cases. And the more aggressive patent holders do even worse: among the most litigated patents - those in eight or more court cases -, holders have won less than $10 \%$ of the cases, ${ }^{285}$ which clearly shows that those patents are extremely weak and, in the majority, invalid and void, as they were granted in non-compliance with patentability requirements which results in strong legal uncertainty for society, and ends up stifling innovation, going against the goals of the patent system.

There was also in the United States - a country that, historically, puts pressure for software patenting -, in 2010, a re-evaluation of the matter. Their Supreme Court, during the Bilski v. Kappos case, change the concept of patenting in the software area, denying the argument that the software should be patented if it is implemented by a machine. It was a political decision seeking to restrict reckless patenting and the stifling of innovation in the technology field in that country. The decision of the Supreme Court obligated the United States Patent Office to publish an internal memorandum about the new patent examination procedure. ${ }^{286}$

283 See lan HARGREAVES, Digital Opportunity. A Review of Intellectual Property and Growth. An Independent Report by Professor lan Hargreaves, 2011, p. 57.

284 See Charles Duhigg e Steve Lohr. Op. cit.

285 See Adi KAMDAR e Daniel NAZER, Deep Dive: Software Patents and the Rise of Patent Trolls, 28.02.2013, available at https://www.eff.org/deeplinks/2013/02/deep-dive-software-patents-and-rise-patent-trolls.

286 See United States Patent and Brand name Office - USPTO, Interim Guidance for Determining Subject Matter Eligibility for Process Claims in View of Bikski v. Kappos, available at http://www.uspto.gov/patents/ law/exam/bilski_guidance_27jul2010.pdf 


\section{EUROPEAN PARLIAMENT REJECTS SOFTWARE PATENTS}

The impact of software patents in Brazil tends to be extremely detrimental for the still incipient national industry. Even in more developed markets such as the European Union, concerns with stifling innovation in the information technology field were the theme of an extensive public debate. In 2005, the European Parliament ${ }^{287}$ rejected software patents by 648 votes, with only 14 favorable votes, in an evident demonstration of the losses that such patents could bring to the European market.

The extremely high costs with litigation involving software patents, which in fact led Microsoft to support a reformation of the United States Patent Act, after having lost a court battle in 2010 that put the sale of its text processor Word at risk, must also be taken into account.

At the risk of enormous social-economic and technological losses for Brazil, no guideline for the examination of patent applications for inventions implemented by software should be adopted before extensive public consultation is conducted regarding the risks and eventual benefits that the practice can offer to Brazil, as well as independent studies in the area.

According to the USP and FGV study, "as the Brazilian Patent office examination guidelines intends to introduce software patents in Brazil when there is not even a national case law understanding about the subject, their 'Guidelines' have the pretense of a normative role, e.g. of law alteration, which is inadmissible for a resolution seat of a Public Administration body." 288 In other words, the Patent Office would be legislating on their own, without so much as a case law understanding about the subject in Brazil, and without any kind of debate or independent study about the risks and benefits of such patents.

Independent studies regarding impact on innovation, competition, balance of trade and social-economic and technological development in Brazil must also be undertaken before the discussion of criteria for examination of such patents. This has been the position of the Ministry of Foreign Affairs before the World Intellectual Property Organization, by means of the Development Agenda. Every, and any, discussion, especially when dealing with such sensitive issues, must be preceded by studies on the impact of new formulations. The position of the 2011 Hargreaves Report on intellectual property and growth by the Government of the United Kingdom goes along the same lines, ${ }^{289}$ as does the Federal Trade Commission of the United States. ${ }^{290}$ The prior realization of independent studies

287 Common Position (EC) n. 20/2005.

288 See Eros Roberto Grau, et. al., op. cit., pp. 7-8.

289 See lan HARGREAVES, Digital Opportunity. A Review of Intellectual Property and Growth. An Independent Report by Professor lan Hargreaves, May 2011.

290 See FEDERAL TRADE COMMISSION, The Evolving IP Market Place - Aligning Patent Notice and Remedies with Competition, 2011, pp. 14-15. 
on the impact of measures concerning sensitive subjects must precede any eventual ruling or regulation about patent rights.

Thus, we suggest that an extensive debate about software patents be conducted, as well as independent studies about the eventual positive and negative impacts that such patents may make on innovation and development in Brazil.

\subsection{Recommendations}

a) To the Executive Branch:

a.1) to the Inter-ministerial Group on Intellectual Property - GIPI:

a.1.1) commission independent technical studies on the potential risks and benefits arising from granting computer-implemented patents for the economy and the technological and social development of Brazil; and

a.1.2) after the consultation mentioned in the item above, debate and approve the Patent Office examination guideline for computerimplemented inventions.

a.2) to the Brazilian Patent Office (INPI):

a.2.1) propose new examination guidelines for computer-implemented inventions, observing, inclusively and necessarily, the patentability requirements standards recommended in this Report, as well as the result of the studies mentioned above, and the abundant national and international literature, and the contributions given by the public consultation of 2012. Launch a new public consultation on the new proposal for the examination guidelines; and

a.2.2) while the studies and the proposal for new guidelines are elaborated and discussed, suspend the examination of patent applications on computer-implemented inventions. 


\section{PATENT PROSECUTION HIGHWAY (PPH)}

Bilateral agreements known as Patent Prosecution Highways (PPHs) were created with the goal of accelerating the process of patent examination by means of collaboration between patent offices in signatory countries. A PPH consists of a fasttrack list among patent applications involving applicants from the signatory countries of a bilateral agreement.

During President Barack Obama’s visit to Brazil in March 2011, the signature of a PPH Agreement between the USPTO and the Brazilian Patent Office was announced. Its goal was to reduce the examination time for patents from the U.S. in Brazil and vice-versa, allowing the offices to rely on the work done by the office that received the first application. From the 13 agreements that were to be signed between the two countries during Obama's visit, the PPH was the only one that was not signed, given the controversy over a lack of debate about the subject in Brazil.

Adhesion to the PPH system is one of the Brazilian Patent Office's proposals to reduce their backlog, or delay in the examination of patent applications reaching for a four-year period of analysis for each patent goal until 2014 against the present eight to ten years for some technological fields such as pharmaceutical. This is a subject of extreme interest for the Brazil-U.S. Business Council, a private sector organization, which announced they are making efforts towards the signature of the PPH. ${ }^{291}$

According to the Brazilian Patent Office, PPH is a mechanism originally proposed by the Japanese as a solution to reduce backlog and avoid repetition of work efforts between offices all over the world. The following countries are said to have adopted it: Japan, South Korea, Australia, Denmark, Finland, Singapore, Hungary, Russia, Spain, Germany, United Kingdom, Austria and Mexico, besides the European Patent Office (EPO). China and Israel would be analyzing the adoption of PPH.

In case a company based in the United States ${ }^{292}$ wants to file a patent for its technology also at the Brazilian Patent Office, it would file the application at the Brazilian office, indicating the preference for the PPH route. It would then provide the entire documentation originally presented to the USPTO. The Brazilian examiner would analyze the U.S. application documents and would then be able to accept the work of the USPTO examiner based on the legislation and public policies of the original patent country.

291 More information at http://www.brazilcouncil.org/task-forces/innovation.

292 Not necessarily North American capital but they must be a legal entity from the United States and the first patent application must have been filed at the USPTO (InovaçãoUnicamp, 2011). 
One of the tasks the national examiner would be able to skip - if he judges the USPTO work sufficient - is the search, the research step where examiner survey several data base of patent offices worldwide to find out whether the application, in fact, is for a novel invention or if there is already a filed or granted patent for a similar invention.

Another step that the PPH advances is the analysis of claims. Usually, each patent application lists everything that the company or inventor wishes to protect. Each discriminated item in the application consists of a claim. The examiners analyze each claim, and are allowed to accept all of them or only some - or to reject the whole. With the PPH, the patent claim that arrives from the USPTO at the Brazilian Patent Office would already have claims previously analyzed by examiners from the U.S.

The Brazilian Network for the Integration of Peoples (Rede Brasileira pela Integração dos Povos - Rebrip), ${ }^{293}$ by means of the Intellectual Property Working Group (GTPI), comprised of 15 civil society public interest organizations such as the Brazilian Interdisciplinary AIDS Association - ABIA, the Brazilian Institute of Consumer Protection (IDEC), the National Federation of Pharmaceutics - FENAFAR, among others, has pronounced itself against this agreement and found great repercussion in the national press.

According to the position of the GTPI (2011), the adoption of this system would feed the the Brazilian Patent Office hopes of artificially decreasing Brazilian backlog. However, the increase in the number of qualified examiners would be the only way to actually reduce delays in the Brazilian examinations and prevent a quality drop, a fundamental item for the granting of patents to respect the constitutional precepts of observing economic, social and technological development in Brazil. In the U.S., there are over 6,000 examiners, while in Brazil there are 273. The report reinforced fears regarding a quality downfall in the examinations, given that the patentability criteria adopted by the USPTO are more wide-ranging. There is an evident disparity in public policies between Brazil and the U.S., bearing in mind, among other factors, the different technological development of both countries.

Therefore, the prior reliance on the examination from the U.S. could lead to the granting of patents for products or processes that, if judged by Brazilian criteria, would be denied. By means of PPH, applications resulting of this agreement would receive a privileged examination, jumping to a quicker line and cutting in front of applications from Brazil and other countries. This aspect would represent a clear advantage for the U.S., which is the leading applicant for patents internationally and in Brazil. In

293 Rebrip is a network that articulates non-governmental organizations, social movements, unions and autonomous professional associations and aims at the observation and criticism of initiatives and treaties about financial and commercial disregulation proposed by organisms such as the World Trade Organization (WTO), the Free Trade Area of the Americas (FTAA), and present in bilateral commercial agreements and between regions such as Mercosur - European Union. 
fact, this discriminatory procedure is contrary to one of the main pillars of the patent system: the principle of the most favored nation. If a benefit is granted to a WTO member country, it is mandatory that it be given to all the other countries (Art. 4 of the TRIPs Agreement).

The opposite, however, does not apply, given that there are still very few patent applications filed in the U.S. that originated in Brazil. Finally, the members of Rebrip claim that the U.S. only surveys English-languages databases for existing patents - in Brazil, other languages are included - and the Brazilian examiner would feel growing pressure towards not repeating the survey already done in the U.S., as the Brazilian Patent Office's clear intention is to reduce backlog. As a counter-argument, the Brazilian Patent Office emphasizes the possibility that there would be patents granted in the U.S. that would not be accepted over here, in which case they would be withdrawn.

The evident need to take the discussion about national interest concerning patents further, without losing sight of the constitutional clause, has led the Brazilian government to lift the signature of the agreement, initially expected to take place during the visit to Brazil of U.S. President Barack Obama in March 2011.

\subsection{Recommendations}

a) To the Executive Branch:

\section{a.1 to the President's Office:}

a.1.1) undertake independent studies prior to the signature of any agreement or partnership between countries or with public bodies of other countries, in order to identify possible positive and/or negative impacts that such agreements or partnerships may have in the economy and to the development of the Brazilian society;

a.1.2) submit patent and related rights issues for prior analysis by the Inter-ministerial Group on Intellectual Property (GIPI) before taking any decision on those matters; and

a.1.3) refrain from signing the PPH agreement as proposed, bearing in mind the previous evidence put forth by this Report.

\section{a.2) to the Patent Office - INPI:}

Submit to prior review and approval by the Inter-ministerial Group on Intellectual Property (GIPI) any proposal to implement collaboration schemes on the examination of patents or trademarks, including but not limited to possible "harmonization" with other Intellectual Property Offices from other countries, such as, but not limited to the e-PEC system. 


\section{PATENT BACKLOG AND PATENT QUALITY}

The Controller General (CGU) of Brazil's Presidency auditted the Brazilian Patent Office in 2011 and found that the Patent Office's indicator / methodology used to assess the backlog of patents (delay in granting patents) is riddled with addiction and therefore has "no usefulness and measurability". 294

The Controller General found that the methodology, nomenclature and data used and presented by the Brazilian Patent Office on the backlog of patents contain flaws that must be corrected. According to the Controller General, "the inclusion of archiving [filing away] decisions made in the denominator made the indicator lose the comparability feature throughout the years" and "the Patent Office has no indicator that displays the total number of patent applications (...) pending decision." 295

The Patent Office, even after the inconsistencies identified by the Controller General, has claimed that their patent backlog has decreased, despite the increase in patent applications pending examination and the decrease in the number of exams.

The amount of patent applications for the Brazilian Patent Office has been increasing year after year (see Table 1, in Chapter 1).

The contingent of patent examiners in the Institute has not been, however, increasing with the patent applications, which has been causing, among other reasons, a considerable delay on patent examinations - known as backlog. In other words, the average delays in the analysis (whether to grant it or deny it) of a patent.

The following graph indicated that the number of patents with pending examinations from 2005 to 2011 has grown 56\%, going from 110,854 applications pending analysis to 173,000 . 


\section{Evolution of Patents Filings with Pending Analyses ("backlog")}

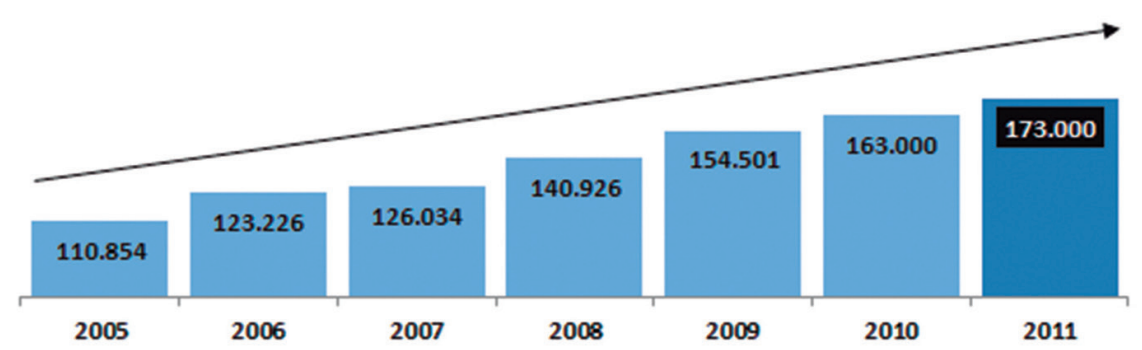

Source: Brazilian Patent Office.

From 2005 on, the number of the Brazilian Patent Office's examiners doubled, which constitutes a laudable improvement. Data from 2008 indicates that the Patent Office had 275 examiners that year. By the end of 2011, according to a management report from the Patent Board (DIRPA) at the Brazilian Patent Office, the number of patent examiners had dropped to 229. In 2012, through public statements from the Office, it is estimated that the Brazilian Patent Office had around 230 patent examiners - fewer in comparison to 2008 due to transfers to other boards, resignations, retirements, among other factors.

Everything points out to the insufficiency of this number of examiners to tackle, without detriment to quality, the growing patent applications filed at the Office.

In 2012, the Brazilian Patent Office published data on a supposed reduction of backlog in patent examinations. According to the Brazilian Patent Office, in 2006, the patent backlog was of 11.6 years. In 2011, still according to the Office, the backlog supposedly dropped to 5.4 years against 8.3 from the previous year, as shown in the following graph:

\section{Backlog of Patent Filings}

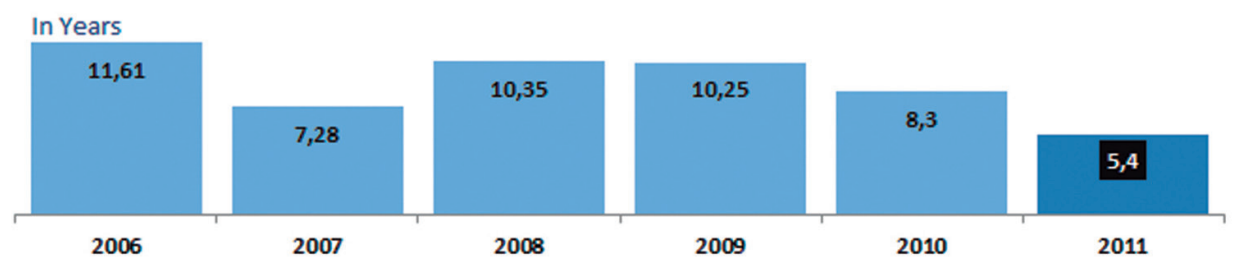


A simple comparison between the two graphs above evidences clearly that at least part of the presented data does not represent reality. The number of patents pending examination has been growing year after year, having reached 173,000 in 2011. Paradoxically, the average time span of applications (without increase in the number of examiners) had supposedly gone down from 8.3 years, in 2010, to 5.4 years, in 2011, according to data published by the Brazilian Patent Office.

The British magazine The Economist published a piece in November 2012 on the supposedly reduction of the patent backlog at the Brazilian Patent Office, relying on data sent by the Brazilian Patent Office itself. ${ }^{296}$ The piece found repercussion among field specialists, including patent attorneys, who suspected the data, since they know that the reality they are faced with everyday does not match the data presented by the Office.

Even before that information had been widely publicized by The Economist, the above-mentioned audit by the Controller General had already taken place, finding that the methodology, the nomenclature and the data used and presented by the Brazilian Patent Office had flaws and needed correction. With the alteration of the criteria the Patent Office used, from one year to another, it would no longer be possible to make a side-by-side comparison regarding backlog increase or decrease, according to Controller General auditors. ${ }^{297}$

As a result from the auditing, the Brazilian Patent Office was forced to recalculate and correct data.

Moreover, the management report of 2011, by the Patent Board (DIRPA) of the Brazilian Patent Office shows that the number of first examinations of patent applications has been decreasing throughout the years. According to the report, in 2009 9,973 first patent applications were examined. In 2010, 7,402 first patent applications were examined. And in 2011, 5,562 first patent applications were examined.

There is evidence, then, suggesting that patent backlog, contrary to what the Brazilian Patent Office publicized, is being increasing steadly instead of decreasing. Some patent attorneys suggest that the present backlog is around 8-10 years - nearly double the figure that the Patent Office was stating.

In any case, a very long delay in patent examination ends up causing legal uncertainty. Uncertainty not only for patent applicants but also for their potential competition, as well as to society as a whole. Applicants do not know if their patents will be granted and, on the meantime (which, nowadays, may last 10 years), they do not know whether they have or do not have exclusive rights to use the claims stated in the patent application.

296 See The Economist, Intellectual Property in Brazil: Owning Ideas - Getting Serious about Patents, 03.11.2012. 297 See Controladoria-Geral da União (CGU), Case: 52400.016890/2012-12, Report no. 201203764. 
The competitors do not know if they can explore the object of the patent application without being at risk of prosecution and fining. And society loses. It loses because it does not know if the one exploring the patent has or will have any rights over it, or if the competition may explore the same object. If there is exploration done by the competition, it may well be that on the next day a court order demands the withdrawal of all products from the market. The population loses. Everyone involved loses. Uncertainty is considerable.

Reducing patent backlog, that is, the time it takes to examine a patent application, is essential for the reduction of this legal uncertainty. For that to happen, more patent examiners need to be employed.

\section{QUALITY OF PATENT EXAMINATIONS}

Quantity does not necessarily mean quality. One of the essential requirements for the patent system not to lose its legitimacy before society is that it be a balanced system. Frivolous or even invalid patents are not suitable to support the legitimacy of the patent system. In that regard, the Federal Trade Commission warns: "[...] poor quality patents can discourage innovation by creating uncertainty and raising costs." 298

However, the quantity of examiners is not the only thing that must increase, but the quality of examinations must be rigorously observed. It is not enough to reduce backlog in patent examinations and, in fact, under that pretext, diminish the quality of examinations. If the quality of examinations is negatively affected, possibly caused by hurrying the examinations to reduce backlog, the patent system as a whole will be harmed and its legitimacy will be shaken.

About that, the Hargreaves Report, from the Government of the United States, is emphatic: "Increased pressure on patent offices to examine the large numbers of applications and reduce these backlogs may lead to the grant of even more low quality patents, worsening the costs of uncertainty." 299

Regarding the patentability requirements as well as the other criteria established by the Patent Act, those also can and should apply, in order to improve the quality of patents in Brazil and, additionally, promote the Constitutional of the patent system. ${ }^{300}$

298 See Federal Trade Commission, "The Evolving IP Market Place - Aligning Patent Notice and Remedies with Competition", 2011, p. 7.

299 See lan Hargreaves, "Digital Opportunity. A Review of Intellectual Property and Growth. An Independent Report by Professor lan Hargreaves", 2011, p. 55.

300 The patentability requirements are discussed in the next chapter. 
One of the several points that may collaborate with the quality in patent examination is the prior survey in other databases, so that an eventual invention that already exists elsewhere is duly identified. To achieve that, financial and technological investments are necessary, as well investment in people.

\subsection{Recommendations}

a) To the Executive Branch:

\section{a.1) to the Brazilian Patent Office (INPI):}

a.1.1) hire ad hoc patent examiners in order to reduce the patent backlog to a number of years considered ideal, within reason, and without detriment to the quality of examination; ${ }^{301}$

a.1.2) hire trained, and to be trained, new patent examiners to compose the permanent staff, with remuneration that complies with the strategic function that they will tackle for the country, so that the total number of examiners will suffice to properly address the large amount of patent applications;

a.1.3) invest in resources so that examiners have access to other patent databases, that will prove helpful in the analysis of the patentability requirements; and

a.1.4) apply high standards to the requirements of novelty, nonobviousness, industrial application, sufficiency of disclosure (enablement) and best mode, at the risk of granting frivolous or invalid patents. ${ }^{302}$

301 See proposal by Ronaldo Mota, Secretary of Technological Development and Innovation, for the Ministry of Science, Technology and Innovation (MCTI), in a lecture given in August 17, 2011, at the Chamber of Deputies, contained in annex $V$ of the Portuguese version of this Report.

302 This is one of the recommendations, in fact, from the respected Commission on Intellectual Property Rights (CIPR) study commissioned by the UK government on the intellectual property system in developing countries. See United Kingdom, Commission on Intellectual Property Rights (CIPR), Integrating Intellectual Property Rights and Development Policy, London, 2002. (http://www.iprcommission.org/papers/pdfs/ final_report/ciprfullfinal.pdf). See next chapter for a more detailed description on the recommendations of this Report prepared by the Chamber of Deputies' Center for Strategic Studies and Debate, in regard to which patentability requirement patterns must be applied. 


\section{CREATION OF THE COUNCIL OF INTELLECTUAL PROPERTY RIGHTS (CODiPI), AND THE ROLE OF THE INTER-MINISTERIAL GROUP ON IP (GIPI)}

There are matters not explicitly defined in the Patent Act that have been generating political and legal controversy among institutions; uncertainties for the stakeholders involved and an increase in intra and extra-governmental judicialization.

Some of those controversies have been exemplified in the present Report, such as the case of prior consent (Brazilian Patent Office - ANVISA), the case of new forms of known substances and new uses (Brazilian Patent Office - GIPI), and the PPH case (Brazilian Patent Office - President's Office/Ministry of Foreign Affairs), among others.

The solution to those controversies is connected to the need for more clarity regarding what kind of policy of patent and related rights the Brazilian State wants and should follow:

a) whether it is a policy based on the U.S., the European or Japanese model, without adjustments to the social-economic and technological reality of Brazil,

b) whether it is a policy that respects the international treaties signed by Brazil, but balanced enough to implement in the national legal framework the safeguards allowed by those treaties, with the aim of respecting other constitutionally established rights such as the fundamental rights and guarantees of access to health, to education, culture and information, as well as the patent clause in the Brazilian Constitution: to promote economic, social and technological development in Brazil.

It all comes down to balance. Balance between private and public interest. Where the Brazilian State grants legal monopoly for a limited time to the inventor, thereby creating rights for this inventor, the very same inventor, on the other hand, has Constitutional duties before society. Patent and related rights do not constitute an end in itself. They are a means to promote economic, social and technological development in Brazil, including training and technology transfer - as is, in fact, determined in the WTO TRIPs Agreement and in the Agreement between the World Intellectual Property Organization and the United Nations.

We seek to bring, through the analysis conducted in this Report, greater balance to the Brazilian patent system, in order to encourage an innovative and competitive market, on one hand, and, on the other hand, the society's access to knowledge goods. With that goal in mind, we present proposals for the improvement of the Patent Act. 
Beyond the proposals hereby presented in the legislative scope, there are several discussions about patent and related rights taking place at the Federal Executive Branch, including Ministries, autarchies and Public Administration organizations and bodies.

For the Brazilian State to have a clear and unified policy concerning patent and related rights, we recommend that the Inter-ministerial Group, following the reformulations hereby presented, becomes the forum in charge of coordinating and unifying the decisions of the several organisms and entities of the Federal Executive Branch regarding patent and related rights, yielding necessarily binding resolutions. In other words, the resolutions adopted by the new Council will no longer be mere suggestions or opinions, but must be binding, consequently, adopted as the country's policy regarding intellectual property and related rights.

If there is a lack of coordination and unification of the position, there is a risk of an installed state of political and legal uncertainty, with potential economic and social consequences that can prove extremely detrimental to the Brazilian State - and could even be explored by foreign States, at our expense.

In that context, the Inter-ministerial Group, in accordance with the reformulations presented as follows, seems to be the most appropriate forum in which to unify the position of the Federal Executive Branch, but, first of all, it is necessary that a political orientation be very clearly defined so that each of the organisms that integrate or may come to integrate the new Council will effectively collaborate in its implementation.

Presently, the GIPI is presided by the President of Camex and comprises 11 Ministries.

The present mission of GIPI, created by a Presidential Decree in 21 August 2001, as revised in 2005 and 2008, is as follows:

Art. 1 It is founded, in the scope of CAMEX - Chamber of Foreign Trade, the Inter-ministerial Group on Intellectual Property - GIPI, with the attribution of proposing governmental action towards the conciliation of internal and external policies with a view to the foreign trade of goods and services concerning intellectual property [...]. (emphasis added)

Camex, in its turn, "is an organism that integrates the Government Council of the Presidency of the Republic and aims at formulating, adopting, implementing and coordinating policies and activities regarding the foreign trade of goods and services, including tourism." 303 (emphasis added; translated from the original)

Camex consists on an organism of foreign trade, eminently. It deals with trade, from the international standpoint. Dealing with promotion of science and technological innovation per se is not among Camex's competencies. Let alone education and culture, or health. Camex's competency concerns commercial aspects, or rather, foreign 
trade. Camex is not competent, therefore, to deal with the promotion of science and technological innovation, or with education, culture, and health.

The commercial relevance, both from the national and the international standpoint, of intellectual property rights, as well as patent rights and copyright is unquestionable. In fact, they possess enormous commercial relevance. In that regard, see data from the Brazilian balance of trade deficit, according to the Central Bank, in Chapter 1 of this Report.

Ever since 1995, the rights of patents, as well as the other knowledge goods such as utility models, industrial designs, integrated circuit topographies, brand names, copyright, geographic indications, computer software's, among others, are part of the Agreement that founded the World Trade Organization - WTO. The commercial character of those rights is undeniable.

The patent and related rights are bestowed by the State, in order to encourage inventive and creative activities, with the final goal of promoting economic, cultural, technological and social development.

Thus, those intellectual property rights serve a specific purpose: to promote scientific, economic, cultural, technological and social progress. The purpose of patent rights, as well as other knowledge goods, is not commercial. The patent clause of the Brazilian Constitution is clear in that respect (Art. 5, XXIX), as are the goals and principles of the WTO TRIPs Agreement itself (Articles 7 and 8). Patent and related rights are a means to promote the development of society. The generation of wealth and commerce are natural consequences, if those knowledge goods are well balanced, but their goal is scientific and technological progress - as well as cultural, in the case of copyright.

In that light, dealing with patents (promotion of science and technological innovation), copyright (culture and education) or patented medicines (health), under the coordination or within an organism that works towards the formulation, adoption, implementation and coordination of policies and activities concerning foreign trade does not appear to us prudent or appropriate.

Leaving the policy of knowledge goods under the coordination of Camex, a strictly commercial body, puts the decisions of the Federal Executive Branch regarding the patent system and knowledge goods in the country at risk of imbalance. There is the risk of not affording due discretion when analyzing other fundamental rights and guarantees provided in the Brazilian Constitution such as access to health, culture, education and related rights.

As demonstrated extensively in this Report, for the patent and knowldege goods system to be balanced, the other constitutional rights and guarantees must be weighed up. Leaving patent and knowledge goods under the auspices of Camex would be a partial 
decision by the Executive Branch. It does not appear to us that the Executive Branch intends to deal with the copyright of didactic books, so important for the promotion of education in Brazil, under the strategic coordination of an eminently commercial body. It does not appear to use either that the Executive Branch wants to deal with medicine patents, for instance, that directly affect the Government programs of access to health programs, within an eminently commercial scope.

According to the Ministry of Development, Industry and Foreign Trade (MDIC), the embryo of the present GIPI arose “in the midst of the 1980's, when there was a need for the coordination of government positions towards the negotiations of intellectual property in the Uruguay Round of GATT" 304 , which culminated in the creation of the WTO, of which the TRIPs Agreement is an integral part. "Pressured by the United States - that had determined unilateral commercial retaliations -, the Brazilian government decides to give in to all demands from the U.S. On a rite of perfection, the Patent Act $[\ldots]$ is written in English and then translated." ${ }^{305}$ Ironically, our present Patent Act was written in English, for foreign commercial interests.

As evident, the origins of GIPI themselves and their continued role that focuses on foreign trade cast light on the risks of bestowing the competency of coordination of such an important area in Brazil upon an organism with essentially commercial goals.

We therefore suggest that the Inter-ministerial Group in charge of discussing and designing public policies regarding intellectual property rights in Brazil be extinct, to give way to the creation of a Council of Intellectual Property Rights housed at the.

\subsection{Legislative proposal}

In face of these considerations, we propose the following Presidential Decree for the creation of the Council of Intellectual Property Rights, housed by the President's Office, with very similar attributions to those of the present GIPI, but with some improvements, such as a clearer objective that the Council shall be guided by the social interest and technological, scientific, cultural, educational and economic development of Brazil; that is, it shall not act eminently under the foreign trade perspective.

Art. 1. The Council of Intellectual Property Rights [Conselho de Direitos de Propriedade Intelectual - CoDiPI] is hereby created under the President's Office.

304 See http://www.desenvolvimento.gov.br/sitio/interna/interna.php?area=3\&menu=1779. translated from the original.

305 See César Benjamin, "Lei de Patentes: Como o Brasil foi vencido", in Atenção, ano 2, n. 4, 1996. translated from the original. According to the Ministry of Development, Industry and Foreign Trade, by means of Inter-ministeriala Ordinance no. 346, of 1990, a commission was created to elaborate the Executive Branch bill aimed at altering the 1971 Patent Act, which resulted in Act 9.279, of 1996. In 1995 GIPI was consolidated in the III CAMEX Meeting. See http://www.desenvolvimento.gov.br/sitio/interna/interna. php?area $=3 \&$ menu=1779. (in Portuguese) 
Art. 2. Considering the social interest and the country's technological, scientific, cultural, educational and economic development, CoDiPI shall:

I - provide stock for the definition of guidelines for the policy of intellectual property rights and related matters;

II - propose the planning for a coordinated action of the bodies in charge of the implementation of the aforementioned policy;

III - issue its resolution beforehand regarding the norms, guidelines and legislation for intellectual property rights and related matters;

IV - appoint technical parameters for bilateral and multilateral negotiations on intellectual property rights and related matters;

$\mathrm{V}$ - propose a coordinated government action directed at the conciliation of internal and external policies;

VI - provide stock on intellectual property rights and related matters towards the formulation and implementation of other public policies;

VII - promote inter-ministerial coordination on subjects tackled by CoDiPI;

VIII - consult with academic institutions of higher learning, with the private sector and non-governmental organizations on intellectual property rights issues and related matters; and

IX - instruct and report on matters concerning intellectual property rights and related matters.

Art. 3. CoDiPI shall be comprised of representatives from the following government bodies:

I - Chief of Staff of the President's Office, who shall be CoDiPI's president;

II - Ministry of Science, Technology and Innovation;

III - Ministry of Development, Industry and Foreign Trade;

IV - Ministry of Culture;

$\mathrm{V}$ - Ministry of Foreign Affairs;

VI - Ministry of Health;

VII - Ministry of Agriculture, Livestock and Food Supply;

VIII - Ministry of Education;

IX - Ministry of Treasury;

X - Secretariat of Strategic Affairs of the Presidency of the Republic;

XI - Ministry of Environment; and

XII - Ministry of Justice.

$\S 1$ The Brazilian Patent Office - INPI, the National Sanitary Agency ANVISA, the Competition Body - CADE, the Brazilian Council for Genetic Heritage Management - CGEN, the Brazilian Institute of the Environment and Renewable Natural Resources - IBAMA, or any other body or entity of the Public Administration, may be heard whenever the subject matter lies within their sphere of competence. 
$\$ 2$ Representatives of other bodies or Public Administration entities as well as field experts may be invited to participate on CoDiPI meetings, in accordance to its regulation.

Art. 4. CoDiPI shall deliberate in plenary sessions, with the possibility of setting up thematic subgroups whenever it is necessary.

$\$ 1$ Both the meetings of thematic subgroups and non-deliberative plenary sessions may have the participation of other members of the Ministries appointed in Article 3, provided that the President of CoDiPI is notified in advance, in accordance to its regulation.

$\$ 2$ CoDiPI shall deliberate through binding resolutions, by simple majority, fulfilling the minimum quota of two thirds of its members, with the casting vote held by the President.

$\$ 3 \mathrm{CoDiPI}$ shall establish its regulation and complementary norms, that shall be approved by absolute majority.

$\$ 4$ The ordinary deliberative meetings of the Council shall be called upon with a minimum of 10 days in advance.

Art. 5. The Executive Secretariat of CoDiPI shall be exercised in accordance to its regulation.

Art. 6. The formulation and implementation of legal norms, guidelines or international instruments on intellectual property rights and related matters by government bodies shall be evaluated and previously approved by CoDiPI, by means of a resolution.

Art. 7. The Inter-ministerial Group on Intellectual Property - GIPI, linked to the Chamber of Foreign Trade - Camex, shall be extinct.

$\$ 1$ The decisions adopted by GIPI shall remain in force.

$\$ 2$ CoDiPI shall restore ongoing discussions at GIPI.

Art. 8. The Decree of 21 August 2001, that created GIPI, shall be revoked.

Art. 9. This Decree comes into force at the date of its publication.

\subsection{Recommendations}

\section{a) To the Executive Branch:}

\section{a.1) to the President's Office:}

a.1.1) evaluate the convenience of signing the Decree proposed above, for the creation of the Council of Intellectual Property Rights CoDiPI, housed by the President's Office.

a.1.2) evaluate the convenience of making the new Council's resolutions binding. 


\section{THE BRAZILIAN PATENT OFFICE (INPI): HEADQUARTERS IN THE FEDERAL DISTRICT}

The Federal Law that created the Brazilian Patent Office (INPI), Law no. 5648 of 11 December 1970, establishes that the Office shall have its "headquarters and fora in the Federal District".

Its present headquarters are in the capital of the State of Rio de Janeiro, which is therefore, illegal.

The transfer of the Patent Office (INPI) to the Federal District has positive aspects, as well as negative. It is undeniable that Rio de Janeiro is a focal point of activities related to the operations of the Patent Office, such as specialized law practices and agents of industrial properties, as well as specialized Court Branches of the Federal Court. Over the last few years, the Brazilian Patent Office began to invest on new premises, as its headquarters building was in poor conditions. Those are the arguments in favor of keeping the Brazilian Patent Office in Rio de Janeiro.

On the other hand, public policy decisions cannot happen away from the Federal District. Bearing in mind that the patent system influences economic, technological and social development in the entire country, it makes no sense for the Brazilian Patent Office to operate in any other locality but the Federal Capital. And that is precisely what is ordered by the Founding Act of the Brazilian Patent Office.

If, by any chance, it is understood that an immediate move of the Patent Office to the Federal District will cause disruptions, we suggest that at least its Presidency, boards and area coordination offices are immediately transferred to the Federal District in order to be close to the public policy decision-making center in the country.

As the years go by, total and complete transition can be undertaken through the reallocation of positions to the Federal District. The law practices and industrial property agents in the area of patents and related rights can file their suit by electronic means, without the need to be in the Federal District. That is already the case with all cases coming from the larges economic and industrial center in the country: São Paulo - as the headquarters are presently in Rio de Janeiro.

In the beginning of the transition to the Federal Capital, the structure of examination, analysis and brand name registrations, patents, geographic indications, computer software and other competency areas of the Patent Office could remain in Rio de Janeiro, while the Presidency, the boards and the area coordination offices would be immediately transferred to the Federal District. As the years go by, further evaluation about the integral transference of the Brazilian Patent Office to the Federal District can be undertaken, as ordered by law. 
The main goal of this proposal is not to enforce the Founding Act of the Brazilian Patent Office but to bring the decision-making activities closer to the Ministries that deal with the subjects related to industrial property rights, as well as to the Presidency of the Republic, in order to promote a policy convergent with national interests of scientific, technological, economic and social development in the country.

\subsection{Recommendations}

\section{a) To the President's Office:}

Consider issuing a Decree establishing that the Brazilian Patent Office's President, Directors, and area Coordinators shall exercise their functions from and in the country's capital, Brasília. 


\section{EXECUTIVE SUMMARY}

Patent law, if duly balanced with other fundamental rights provided by Article 5 of the Brazilian Constitution, should promote technological innovation do Brasil aimed at scientific, technological, economic and social development. The patent system must, therefore, encourage technological innovation as well as, on the other hand, the access to those innovations and to technology training, keeping the balance between exclusivity and competition. ${ }^{306}$ In this regard, the Federal Trade Commission of the United States of America is clear:

Invalid or overbroad patents disrupt that balance by discouraging follow-on innovation, preventing competition, and raising prices through unnecessary licensing and litigation. ${ }^{307}$

Without proper balance, the patent system fails to exercise its constitutional role and consequently must be reformed (by the Legislative Branch), reinterpreted (by the Judicial Branch), and its public policies must be reconsidered (by the Executive Branch), so as to achieve the balance needed for the promotion of economic, social and technological development in Brazil, meeting the demand of the patent clause of the Brazilian Constitution (Art. 5., XXIX).

The Prime Minister of the United Kingdom, at the time of the commission of the Hargreaves Review of Intellectual Property and Growth, in 2011, came up with the following question for Professor Ian Hargreaves, in charge of the Review: "Could it be true that laws designed more than three centuries ago with the express purpose of creating economic incentives for innovation by protecting creators' rights are today obstructing innovation and economic growth? The short answer is: yes." 308

Ultimately, in light of national interest, this Report aims at: i) providing stock for a legislative review in the field of patent law and related rights; ii) proposing recommendations for interpreting and applying the sector legislation by the Brazilian Patent Office, among others, and iii) helping on decision-making processes regarding public policies for national development.

306 A position shared by the Federal Trade Commission of the U.S. (the equivalent government body in Brazil is Conselho Administrativo de Defesa Econômica - CADE) in their report entitled The Evolving IP Market Place - Aligning Patent Notice and Remedies with Competition, 2011, p. 1. Available at http://www.ftc.gov/ os/2011/03/110307patentreport.pdf.

307 See Federal Trade Commission, The Evolving IP Market Place - Aligning Patent Notice and Remedies with Competition, 2011, p. 1.

308 See lan Hargreaves, Digital Opportunity. A Review of Intellectual Property and Growth. An Independent Report by Professor lan Hargreaves, 2011, p. 1. 


\section{Incentive to innovation through patent rights}

The patent system was not conceived as an end within itself. Protecting patents is not the objective of the patent system. The objective is promoting non-obviousness, technological advancement as well as technological training and transference, with equitable remuneration for the inventor and a view to a bigger goal: that of promoting the scientific, economic, social and technological development. It is, therefore, a means, and not and end in itself.

The Gowers Report by the Government of the United Kingdom makes itself clear by stating that, even the minimum standards for intellectual property rights provided by TRIPs "have proven very burdensome for some developing countries". ${ }^{309}$ Let us talk about TRIPs-plus clauses, then, that is, clauses that go beyond the minimum standards demanded by TRIPs, such as pipeline patents, patents for new uses and forms (new uses and new forms of known substances), as well as exclusive rights to test data; themes treated on Chapters 6, 7 and 9, respectively, in this Report.

According to the Gowers Report, it is true that a relationship between strong patent rights and elevate growth has been proven, but not a cause and effect relationship. ${ }^{310}$

\section{IMITATION WAS ESSENTIAL TO TODAY'S DEVELOPED COUNTRIES}

According to Chang (2001 and 2009), the historical experience of countries that are today developed reveals that a strong protection to patents was not an essential condition to their economic development. Most of them adopted a lighter, incomplete, system of protection until they caught up with the advanced stages of development, and many violated other countries' patent rights. ${ }^{311}$

Holland, for instance, has integrally revoked their patent act for 47 years, from 1869 until 1910, so that the country could freely imitate the inventions in the chemistry field from Germany, their neighbor. ${ }^{312}$

And, after consolidating their technological position, those countries that had adopted weak protection, or even abolished their patent laws, took their turn in perfecting the international system of patent protection and demanding protective parity from countries that had not yet matured, and that had not achieved a substantial level of technological development according to the standards set by the now developed nations.

309 See UNITED KINGDOM, Gowers Review of Intellectual Property, report by the Government of the United Kingdom, 2006, p. 59.

310 See Reino Unido, "Gowers Review of Intellectual Property", relatório do governo do Reino Unido, 2006, p. 58.

311 See also, Fábio Konder COMPARATO, A transferência empresarial de tecnologia, 1984.

312 See Adam B. JAFFE and Josh LERNER, Innovation and Its Discontents - How our Broken Patent System is Endangering Innovation and Progress, and What to Do About it, Princeton, 2004, pp. 86-90. 
WORLD BANK CONCLUDES THAT THERE IS NO SET RELATIONSHIP BETWEEN FOREIGN DIRECT INVESTMENT AND PATENT PROTECTION

The World Bank, in a 2005 Report, concluded that "[e]vidence is inconclusive about the responsiveness of FDI to intellectual property regimes". ${ }^{313}$

\section{WORLD BANK: PRODUCTION OF PATENTED PHARMACEUTICALS HAPPENING OUTSIDE DEVELOPING COUNTRIES IN SPITE OF PATENT EXISTING IN THOSE COUNTRIES}

Patent protection drove several multinational pharmaceutical companies to stop or refrain to start production and investment in developing countries and instead supply these markets with products from the North. ${ }^{314}$

\section{BRAZILIAN LABORATORIES TRIED TO WARN ABOUT SERIOUS ISSUES INVOLVING the Patent Act When it Was under negotiation in the 1990's}

According to Carlos Alexandre Geyer, President of the Association of National Pharmaceutical Industries (Alanac), during the negotiations that took place in the 1990s on the present Patent Act, associations representing the Brazilian pharmaceutical industry such as the Brazilian Association of Chemical and Biotechnology Industries and its Specialties (Associação Brasileira das Indústrias de Química Fina, Biotecnologia $e$ suas Especialidades - Abifina) and Alanac tried to "convince society and the congresspersons that what they were going to approve, mainly due to a demand by the United States, would certainly bring trouble in the future for our [Brazilian] industry (...). We've had some success in the Chamber of Deputies but, when the project reached the Senate, it was completely amended under pressure to fulfill demands mainly from the United States (...). We, as opposite to, for instance, Argentina, and presently India, did not take advantage of the safeguards allowed by international legislations. (...) In some ways, the present Patent Act in Brazil is even more rigorous that the United States' legislation (...). Unfortunately, our pharmaceutical industry has been trashed. (...) The great majority of congressional representatives who voted for the present patent legislation was not aware of its fundamental objectives, of which they were voting for. Nowadays I believe that society has evolved in that regard, outside of the pressures we feel from other industry sectors, from other exporting industries in Brazil. In the State of Rio Grande do Sul, in spite of the good intentions from the directors of the

313 WORLD BANK, Global Economic Prospects 2005. Washington, 2005. p. 110. Apud JAGUARIBE, Roberto et al. Propriedade intelectual: espaços (...), op cit. p. 292.

314 WORLD BANK, Global Economic Prospects 2005, op. cit. Apud JAGUARIBE, Roberto et al. Propriedade intelectual: espaços (...), op cit. p. 292. 
Federation of Industries of the State of Rio Grande do Sul (Federação das Indústrias do Estado do Rio Grande do Sul - FIERGS) and in spite of the fact that the then president of FIERGS was from the pharmaceutical industry, we could not get enough support to our struggle, to our claim for a suitable patent legislation, because the leather and footwear sector, which is extremely strong in Brazil, was under a threat from the government of the United States that they would cease to import Brazilian shoes. (...) The Brazilian society was used, industrial sectors, exporters at that time, were used as pressure tools for this patent legislation to get approval." 315

\section{Statistics evidence that the present Patent System HAS BEEN MORE BENEFICIAL TO FOREIGNERS}

After the Patent Act came into force in 1997, the participation of "non-residents" has increased and remained around 75-80\% of the patent filings in Brazil (Table 1), which shows, among other things, that the costs of maintenance of the patent system in Brazil is being directed, as a priority, to the protection of foreign, instead of national, patents.

It is important to highlight that foreign companies with legally established offices in Brazil are included in the concept of the expression "residents". Therefore, "resident" does not refer to the national industry, but to the sum of national businesses and foreign businesses with legally established branches in Brazil.

A research conducted by Reis (2012) evidences that "six countries dominate $90.5 \%$ of the total patent filings for antiretroviral medicines in Brazil, with companies from the United States being the chief patent holders, with $62 \%$ of patents. Brazil corresponds for $2.3 \%$ of the filings." 316

\section{The Patent System is being used as a mechanism of transfer of Resources FROM LESS TECHNOLOGICALLY DEVELOPED COUNTRIES TO WEALTHY COUNTRIES}

In 1993, the Brazilian deficit in intellectual property rights reached US\$ 86 million. In 2012, after the creation of the WTO and after the Patent Act came into force, this sum

315 See comments by Carlos Alexandre Geyer, President of Alanac (National Pharmaceutical Laboratories Association) during the roundtable "Harmonização internacional: o futuro do tratado substantivo da Lei de Patentes e suas implicações para os países em desenvolvimento" (in Portuguese), from the Patents, Innovation and Development International Seminar (Seminário Internacional Patentes, Inovação e Desenvolvimento - SIPID), held by Abifina (Brazilian Association of Chemical and Biotechnology Industries and its Specialties) in 5 and 6 July 2007, in Rio de Janeiro, available at http://www.abifina.org.br/arquivos/ II_sipid_3_hormonizacao.pdf.

316 See Renata REIS, Panorama Patentário dos Medicamentos Antirretrovirais no Brasil. Ongoing doctoral thesis from the Graduate Program in Public Policies, Strategies and Development of the Institute of Economy, Federal University of Rio de Janeiro, 2012. 
reached US\$ 3.1 billion, according to data from the Central Bank of Brazil - which indicates losses of over 3,600\% (three thousand and six hundred per cent).

This data suggests that the intellectual property rights regime is functioning as a mechanism of income transfer from developing and least developed countries to economically central countries, in the opposite flow than the stipulated by its goals and by the reasoning used by more technologically developed countries during the TRIPs negotiations at the WTO.

In the words of Joseph Stiglitz, Nobel Prize laureate in economics, "the patent system is a distortionary and, with the huge transfers that might result from the poor countries to the rich, a potentially inequitable system of funding research. The huge transfers clearly can have an adverse effect on development." 317

\section{BRAZIL HOLDS LESS THAN $0.3 \%$ OF PATENT APPLICATIONS IN THE WORLD}

After ten years from the introduction of the Patent Act, there has not been an evolution of the Brazilian participation in the world scenario regarding patent filings. The participation of Brazilian filings regarding the world total has remained at $0.28 \%$, which means less than 0.5 per cent. ${ }^{318}$ That figure remains the same.

\section{Foreigners have benefitted more from the Patent System in the PHARMACEUTICAL FIELD THAN THE NATIONAL INDUSTRY}

Among the 278 pharmaceutical patents granted by the Brazilian Patent Office between 2003 and 2008 identified by the above-mentioned study, only one is held by a Brazilian.

\section{TECHNOLOGY TRANSFER CONTRACTS IN THE PHARMACEUTICAL FIELD DROPPED BY ALMOST 70\% AFTER TRIPS ENTERED INTO FORCE}

FIOCRUZ evidences that there was an almost $70 \%$ decrease in the number of technology transfer contracts in the pharmaceutical field, dropping from 110 in 1992 to 34 in $2001 .^{319}$

317 STIGLITZ, Joseph E. Towards a pro-development and balanced intellectual property regime. WIPO: Seoul, 2004. p. 10.

318 Considering Brazilian filings in national and international offices, against the total world filings. The average was $0.39 \%$, including filings from Brazilian residents (which comprise foreign businesses with legally established branches in Brazil) against total filings from residents in the world between 1997 and 2007.

319 See OLIVEIRA, M.A.; BERMUDEZ, J.A.Z.; CHAVES, G.C. et al., op. cit. 


\section{COMPETITION WITH GENERIC MEDICINES FORCES AIDS DRUG PRICES TO DROP FROM US\$ 10,439 TO US\$ 67}

In the case of AIDS treatment, due to competition from generic medicines, the price of the first line triple therapy (estavudine, lamivudine and nevirapine) dropped from US\$ 10,43900 per patient per year in 2000 (lower original price) to US\$ 67 per patient per year (lower international price - generic Aurobindo, Matrix and Cipla) in 2010.320

\section{BRAZIL SAVED OVER US\$ 1 BILLION WITH GENERIC ANTIRETROVIRALS}

In Brazil, a study conducted in the end of 2007 suggested savings of public resources of over US\$ 1 billion from 2001 to 2005 regarding the purchase of six antiretroviral drugs alone, due to the negotiation of prices in an international competition scenario made possible by the existence of generic medicines. ${ }^{321}$

\section{The patentability requirements and patent quality}

The three patentability requirements present today in the Brazilian Patent Act, novelty, non-obviousness and industrial application - as well as the other two criteria of the social contract established by the patent system, sufficiency of disclosure and best mode -, must be rigorously observed both by the Brazilian Patent Office and the Judicial Branch, as invalid or frivolous patents - therefore lacking in quality - could otherwise be granted. ${ }^{322}$

The three requisites are: (a) novelty, that is, it is imperative that the invention is different from everything that has become accessible to the public before the filing date of the patent application, by written or oral description, by use or any other means, in Brazil or abroad; (b) non-obviousness, by which it is understood that the invention cannot be considered evident or obvious by a person skilled in the art and (c) industrial application, which is the possibility that the invention may be used in any kind of industry. As already mentioned, in addition to the traditional requirements, there are other two criteria that are part of the social contract established by the patent

320 DOCTORS WITHOUT BORDERS (DWB), Untangling the Web, 2010. Available at www.utw.access.org.

321 NUNN, Amy S. et al. Evolution of antiretroviral drugs costs in Brazil in the context of free and universal access to AIDS treatment, PLOS Medicine: November 2007, Volume 4, Issue 11, e305, p1804. Available at http://www.plosmedicine.org/article/info:doi/10.1371/journal.pmed.0040305. Access in 4 February 2009.

322 In this regard, the recommendation contained in the Hargreaves Report, by the government of the United Kingdom, is that it must be ensured that only high quality patents are granted. See lan Hargreaves. Digital Opportunity. A Review of Intellectual Property and Growth. An Independent Report by Professor lan Hargreaves, 2011, p 58. 
system to create a balance between the personal interests of the patent holders and the public interest in access to patented technologies: (d) sufficiency of disclosure, which demands that the product or process for which the patent is filed is clearly and sufficiently describe so that a person skilled in the art can be fully capable of producing the patent and, lastly, (e) best mode, which demands that the best mode of execution of the invention is expressly detailed under risk of invalidation that the best mode of execution of the filed invention is expressly detailed under risk of ingringement. ${ }^{323}$

The CIPR Report commissioned by the government of the United Kingdom, while analyzing which are the best measures to be adopted by developing countries for their respective patent systems, recommended that the patentability requirements be applied according to "higher standards of patentability than those currently provided in many developed countries". ${ }^{324}$ That is precisely what emerging States such as India and China did recently with the revisions of their Patent Acts in 2005 and 2008, respectively. ${ }^{325}$

\section{Novelty}

We recommend that Brazil continue to adopt and apply the regime of absolute novelty, to prevent non-innovative patents from being unduly granted. In fact, in a truly globalized world in which the WHO exists, it does not come off as sensible to adopt the principle of relative novelty.

\section{NON-OBVIOUSNESS}

The requisite of non-obviousness is crucial for the employment of public policies consistent with the present stage of technological development in Brazil, and also so that patent system respects the Constitutional patent clause for promoting technological, economic and social development (art. 5, XXIX, of the Brazilian Constitution).

In that regard, the Gowers Report, by the government of the United Kingdom, recommends: "the removal of poor quality patents will improve the quality of the stock

323 Novelty is provided in Articles 11 and 12; non-obviousness, in Art. 13, combined with Articles 11 and 12; industrial application is provided in Art. 15; sufficiency of disclosure, in Art. 24, and best mode of execution in Art. 24, all articles from Act 9.279/96.

324 See United Kingdom, Commission for Intellectual Property Rights (CIPR), Integrating Intellectual Property Rights and Development Policy, London, 2002. Available at <http://www.iprcommission.org/papers/pdfs/ final_report/ciprfullfinal.pdf>.

325 India reviewed its Patent Act in 2005 and implemented higher patentability requirements. See Feroz Ali Khader, The Law of Patents - With a Special Focus on Pharmaceuticals in India, LexisNexis Butterworths, 2007, and Srividhya Ragavan and Feroz Ali Khader, Proof of Progress: The Role of the Obviousness Standard in the Indian Patent Office, Global Perspectives on Patent Law, 2012. China reviewed its patent act in 2008 and implemented higher patentability requirements. See EU-China Project on the Protection of Intellectual Property Rights (IPR2), Third Revision of China's Patent Law: Legal texts and documents on the drafting process 2006-2008, 2010. 
of patents. [...] This can be achieved by a stringent application of the novelty test and the inventive step test $[\ldots]$ "..326

The non-obviousness requirement should be used towards encouraging sequential innovation, also known as follow-on innovation, or improvements over an initial innovation.

The Federal Trade Commission of the U.S. suggests, for instance, that the nonobviousness requirement should be applied with a certain degree of rigor, even in their country, which boasts a high level of technological development; and gives the following recommendation for the ideal application of the non-obviousness requirement: if the invention that is the object of analysis was already going to arise (and be commercially explored and publicized) very soon, then this invention does not deserve to be patented.227

\section{SUFFICIENCY OF DISCLOSURE}

In the chapter about the patent application, the Brazilian Patent Act makes itself clear in demanding that " $[\mathrm{t}]$ he report must describe the object clearly and sufficiently, enabling its production by a field expert, and also indicate, when applicable, the best mode of execution." (emphasis added - Art. 24). In addition to the sufficiency of disclosure in the report, claims must mandatorily be justified, with indication of the specificities of the application, defining clearly and precisely the object-matter of protection. (Art. 25) ${ }^{328}$ (translated from the original)

The insufficiency of disclosure of a patent object is contrary to the Constitutional patent clause (Art. 5, XXIX). If there is no sufficiency of disclosure, the competition will be harmed and, consequently, there will be damages to consumers and society. The patent system was designed with a careful balance in mind: on one hand, the State grants temporary legal monopoly to the inventor and, on the other hand, the inventor must describe exactly and clearly their invention, enough to enable a field expert to execute or produce the invention that the patent object, in order to promote technological qualification. If there is insufficiency of disclosure, the patent is unconstitutional and invalid. ${ }^{329}$

326 See United Kingdom, Gowers Review of Intellectual Property, report by the government of the United Kingdom, 2006, p. 82.

327 See Federal Trade Commission, op. cit., Chapter 4, p. 6.

328 Article 25 - "The claims must be based on the specification, characterising the particularities of the application and defining clearly and precisely the subject matter to be protected."

329 According to Articles 46 and 48 of the Patent Act, the patent granted in contradiction with the provisions of the Act will be invalid, and its invalidity will be effective from the application filing date. 


\section{BEST MODE}

Another point to be observed that complements the integral description of the invention (sufficiency of disclosure) is the disclosure of the best mode of execution, in line with the U.S.'s ruling. Along with the contents claimed in the patent application, the best mode of proceeding towards the production of the invention must be integrally described; otherwise, the patent can be deemed invalid.

Art. 24 of the Brazilian Patent Act demands that "[t]he report must describe the object clearly and sufficiently, to enable its production by a field expert, as well as indicate, if applicable, the best mode of execution." (emphasis added; free translation)

Thus, in order that the Constitutional patent clause be respected, the criterion of best mode for an invention must necessarily be observed, or the patent will otherwise be deemed invalid - otherwise, the social contract established by the patent system would not be observed, disrupting the balance created between private and public interests.

The adoption of higher standards in the patentability requirements is an incentive to capacitation and technological development in Brazil, since, considering we are less developed than, for instance, the U.S., Europe, Japan and South Korea, we will have the legal possibility (without infringement of foreign patents) and the time needed to increase our level of technological development. This was precisely the public policy adopted by both South Korea and Taiwan, for their technological development: first, imitate technologies developed by other countries and then develop own technologies.

\section{Recommendations}

a) To Congress:

a.1) approve Bill H.R. 5402/2013 to encourage sequential and incremental innovation through an increase in the quality of patents, and through the application of a high standard for the inventive step requirement (see Art. 3 of Bill 5402/2013, attached, that amends Articles 13 and 14 of the Patent Act).

b) To the Executive Branch:

\section{b.1) to the Brazilian Patent Office (INPI):}

b.1.1) apply the sufficiency of disclosure criterion so that the description of the object and the patent claims is, necessarily, sufficient, clear and complete to allow for all aspects of the invention to be executed, in a precise manner, by a person having ordinary skill in the art, at risk of the patent being invalid and unconstitutional otherwise; 
b.1.2) apply with due rigor the best mode criterion to ensure that the patent applicant does not hold on to information that could be useful to third parties, at the risk of the patent being invalid and unconstitutional otherwise;

b.1.3) apply with due rigor the absolute novelty requirement, to prevent the grant of patents that are not truly innovative, at the risk of the patent being invalid and unconstitutional otherwise; and

b.1.4) apply with due rigor the non-obviousness requirement to prevent frivolous patents from being granted, aimed at stimulating sequential or incremental innovation.

\section{b.2) to the Sanitary Agency - ANVISA:}

b.2.1) apply the sufficiency of disclosure criterion so that the description of the object and the patent claim in the health field are, necessarily, sufficient, clear and complete to allow for all aspects of the invention to be executed, in a precise manner, by a person having ordinary skill in the art, at the risk of the patent being invalid and unconstitutional otherwise;

b.2.2) apply with due rigor the best mode criterion to ensure that the patent applicant in the health field does not hold on to information that would be useful to third parties, at the risk of the patent being invalid and unconstitutional otherwise;

b.2.3) apply with due rigor the absolute novelty requirement, to prevent patents in the health field from being granted when they are not truly innovative, at the risk of the patent being invalid and unconstitutional otherwise; and

b.2.4) apply with due rigor the non-obviousness requirement, so that frivolous patents in the health field are not granted, in order to encourage sequential or incremental innovation. 


\section{Pre-grant opposition}

\section{RENOWNED STUDIES RECOMMEND PRE-GRANT OPPOSITION}

Professors from Harvard and Brandeis universities Josh Lerner and Adam Jaffe recommend the creation of an opposition system before the granting of patents in their country. ${ }^{330}$ The CIPR Report by the Government of the United Kingdom makes the same suggestion. ${ }^{331}$

\section{SOCIETY PARTICIPATION IN THE PRE-GRANT OPPOSITION MECHANISM}

The 1969 Act went beyond and required, in case of opposition by third parties, an additional examination, letting the Brazilian Patent Office decide whether to consult with persons having skill in the art such as university professors. This is an exemplary procedure and runs side by side with the natural evolution of society, consisting of a collaborative and peer-reviewed work. This measure tends to increase the quality in patent examination and, consequently, the quality of granted patents - which would leave less room for invalid or void patents and legal uncertainty.

\section{PRE-GRANT OPPOSITION: \\ WORLDWIDE TENDENCY TO IMPROVE THE QUALITY OF PATENTS}

There is a worldwide movement for the adoption of pre-grant opposition to patents. As mentioned before, both India, in 2005, and China, in 2008, have altered their patent acts to implement the pre-grant opposition to patents. Despite the fact that the U.S., for instance, do not adopt a pre-grant opposition to patents process, they provide for a re-examination administrative procedure after granting the patent. For some years now there has been an ongoing debate and tentative planning for a system of pre-grant opposition to patents in the U.S., precisely aimed at increasing the quality of granted patents and consequently avoiding long and costly litigation processes as well as great legal uncertainty prompted by the existence of too many invalid patents.

330 See Adam B. Jaffe and Josh Lerner, Innovation and Its Discontents - How our Broken Patent System is Endangering Innovation and Progress, and What to Do About it, Princeton, 2004, pp. 180-183.

331 COMMISSION ON INTELLECTUAL PROPERTY RIGHTS. Integrating intellectual property rights and developing policy, Report of the Commission on intellectual property rights, London, UK 2002. 


\section{Recommendations}

\section{a) To Congress:}

a.1) approve Bill H.R. 5402/2013 to implement a pre-grant opposition mechanism - that will increase the quality of patents and substantially decrease legal uncertainty caused by frivolous or invalid patents (see Articles 3 and 4 of Bill 5402/2013, attached, that amends Art. 31 and creates Art. 31-A of the Patent Act).

\section{b) To the Executive Branch:}

\section{b.1) to the Brazilian Patent Office (INPI):}

b.1.1) invest in and improve the Brazilian patent database in order to offer, through open standards, open access to precise and detailed results on the evolution of all patent applications and the status of every granted patent to all;

b.1.2) implement, as soon as possible, search methods allowing for swift and easy access to all documents about chemical-pharmaceutical and biotechnological products and processes.

\section{b.2) to the Ministry of Science, Technology \& Innovation:}

Develop a program to enhance the participation of experts (professors, students, or any interest party), in the process of patent examination, in order to improve the patent quality, and to help the Brazilian Patent Office examiners in identifying the state of the art (non-obviousness requirement), as well as the novelty requirement, aimed at increasing the patent quality.

\section{Non-extension of the patent term}

A patent term must, as high impact factor in the access to patented goods and so that the patent system remains duly balanced, consist of the time that is strictly necessary to allow for the financial recovery of the investment made by the patent holder - not a day less, nor a day more.

As the granting of a patent may have a negative impact in the access to the patented object because it can limit competition as well as buying options to a sole supplier, which leads to elevated prices due to the temporary legal monopoly, some checks and balances must be employed. In the case of pharmaceutical products, for instance, the patent grant gets in the way of health oriented public policies, besides limiting access to proper treatment by a large part of the population because of high prices stipulated by the patent holder. Thus, the patent term must be limited to what is established in international agreements between countries, without allowing for extensions. 
The WTO TRIPs Agreement established a minimum patent term of 20 years. Any longer term would alter the exchange system between public and private interest established between society and the patent holder and goes beyond what was stipulated by international agreements signed by Brazil concerning patents.

The extension of the patent term because of a delayed grant is a TRIPs-plus measure and, as such, must be excluded from the Brazilian Patent Act, with a view to the social interest in accessing patented technology as soon as the 20-year term expires, especially for technologies that make an impact on the actualization of human rights, as is the case of medicines.

The present Brazilian Patent Act fixes the term of a patent in 20 years from the filing date or 10 years from grant date, in case it is delayed (Sole paragraph of Article 40 of the Patent Act).

In other words, if there is a difference of more than 10 years between the filing date and the grant date, the patent term will be of more than 20 years from the filing date. The sole paragraph of the Article 40 of the Patent Act, then, creates, based on the ineffectiveness of the Brazilian Patent Office, the possibility of an unreasonable extension in the protection term afforded by the patent, to the detriment of public interest.

It is worth stressing that the WTO TRIPs Agreement does not demand this minimum protection of 10 years counting from the patent application date.

There are attempts to extend the patent terms for several years beyond the maximum protection term of 20 years. There was a plea for the extension of the term for the Bifentrina patent, which was filed in 1979, which means a 37-year term, which means 17 years beyond the usual term for a patent. ${ }^{332}$

The most important move is to equip the Brazilian Patent Office with the necessary conditions to fulfill their fundamental role within reasonable deadlines instead of creating conditions to increase protection term depending on the present ineffectiveness of the Brazilian Patent Office in examining all filed patent applications in a swift manner.

\section{Recommendations}

a) To Congress:

Approve Bill H.R. 3.944/2012, sponsored by Congresswoman Jandira Feghali and others, proposing the revocation of the Patent Act Article 40's sole paragraph (see also Art. 2 of Bill H.R. 5402/2013, attached). 


\section{Public non-commercial uses}

By means of the government use mechanism, also known as public non-commercial uses, the State has the right to use, or to authorize the use by third parties in their name and for specific non-commercial ends, any patent granted, whether of a product or process, after communicating the patent holder and fixing proper remuneration, according to the provision of the WTO TRIPs Agreement. It is important to highlight that the government use also applies in case a private entity produces a good destined to be exclusively purchased by the State (CORREA, 2002).

This remuneration is not equivalent to the royalties usually fixed for voluntary or compulsory licensing with commercial purposes. It is about establishing remuneration to the patent holder that is not attached to profit aspects, as the technology that is subject to government use serves the public interest and is not employed in obtaining profits.

This institute gives the State the opportunity to correct certain situations in which patent and industrial creations rights hamper the access to essential technology.

The Brazilian Patent Act contemplates the many safeguards while being remiss regarding the important safeguard that is government use. Despite being absent in the Patent Act, the institute of government use is not a stranger to the Brazilian legal framework as it is present on Act 11.484, from 31 May 2007, regarding the protection to integrated circuit topography, also known as chips.

The inclusion of the public non-commercial uses safeguard in the Brazilian law regulation patent and related rights can offer society and the public interest an important tool for balance, as provided and authorized by the multilateral rules of the WTO, to propel public policies aimed at meeting important social demands regarding national defense, education, food security, technological development, as well as public health.

As established by the WTO TRIPs Agreement itself, in case of non-commercial public use, for instance, there is no obligation of prior negotiation with the patent holder, with the other conditions remaining valid, including mandatory remuneration of the patent holder. In cases of government use, there is not even the obligations of emitting a license; remuneration of the patent holder being the only obligation. (LOVE, 2002, p. 74).

In general terms, if compared to the emission of a compulsory license, government use of patents is similar, but it is a much more direct and less restrictive sort of permission of use without previous holder authorization which can be perfectly adjusted to society's interests that lack, for instance, drugs priced reasonably according to local purchase power, as well as the need for access to technology towards local production (LOVE, 2002, p.75). It befits to point out that not only can local production of goods be authorized by the government but importing the product for government use is also 
permitted (LOVE, 2002, p.75), as it is possible for a private organization to produce a good for the exclusive use by the State (CORREA, 2002).

The Brazilian legislation established several foundations for the emission of compulsory licenses; however, it has not established a simpler method for the government use of patents as many other countries' legislations have. In Brazil, the Patent Act, in its Article 68 , provides that the holder will be subject to have their patent compulsorily licensed if they enjoy their rights in an abusive manner or if the patent is used towards the abuse of economic power.

Following the example of several technologically developed countries, a more simplified and less restrictive mechanism for the governmental or public non-commercial use of patents must be adopted by Brazil, as permitted by the WTO, independently of the compulsory license issuance hypotheses, which will remain ruled by existing legislation.

\section{EXAMPLES OF COUNTRIES THAT AUTHORIZE GOVERNMENT USE OF PATENTS}

According to James Love (2002), several countries have solid laws for the public use of patents. In the United States (Section 28 of the United States Code, paragraph 1.498), for instance, the government can use a patent or authorize third-party use for practically any public use without previous negotiation. Patent holders do not have the right to question the validity of such use, and may only question the established remuneration. ${ }^{333}$ Similar mechanisms were adopted by the legislations of several countries such as Australia, Ireland, Italy, Germany, New Zealand, Philippines, Malaysia, Singapore, among many others (Love, 2002).

The United Kingdom has also adopted a similar mechanism to allow the use of a patented invention by the government or third parties authorized by the government (Article 55 concerning the use of patented inventions by the Crown). ${ }^{334}$ In India, the government or any authorized person may use a patented invention for government purposes, upon remuneration. (Article 100). ${ }^{335}$ Canada, Spain and China also integrate the extensive list of countries that provide for public non-commercial use of patents in their legislations. ${ }^{336}$

The U.S. are the country that most extensive and intensively employs the government use of patents, especially for government programs concerning defense and energy, but also in the health protection field, of which the cases of Meprobamate and Tamiflu.

333 Oliveira, Marcos. Medicamentos essenciais e licenças governamentais. Facto Abifina, 5th edition, Jan/Feb 2007.

334 Oliveira, Marcos. op. cit.

335 Idem.

336 Idem. 
The American law institutes government use on Section 28, Paragraph 1.498 of the U.S. Code.

The dispositions listed on Article 31 of the TRIPs Agreement do not refer exclusively to the use of compulsory license, but also non-commercial public use. This differentiation is important from the legal framework standpoint, as there are substantive differences between compulsory licenses and governmental or non-commercial public uses. That is why we propose improvements to the Patent Act.

\section{Recommendations}

\section{a) To Congress:}

Approve Bill H.R. 5402/2013 in order to implement in the Patent Act the noncommercial public use safeguard provided for by the WTO TRIPs Agreement (see Art. 4 of Bill 5402/2013, attached, that creates Art. 43-A of the Patent Act).

\section{Pipeline patents (or revalidation patents)}

Pipeline patents are also known as revalidation patents.

Pipeline patents introduced the possibility of filing patents in technological areas (chiefly medicines and foodstuffs) for which Brazil did not previously grant patents until the present Patent Act came info force, as provided in Articles 230 and 231, of Act 9.279/96.

Those patents underwent a different processing mechanism from the other patents applicationed in Brazil. By this mechanism, the pipeline patent application could be filed at the Brazilian Patent Office for a year after the Act came into force, between May 1996 and May 1997, and would "revalidate" nationally patents for medicines, foodstuffs and chemical-pharmaceutical products granted in other countries.

Those applications coming from abroad only went through a formal analysis and followed the conditions of the patent granted abroad, skipping a technical analysis of the patentability requirements of the Brazilian Patent Office. In that regard, Brazil forfeited the ability to interpret the patentability requirements according to its own criteria and interests.

Pipeline patent applications as described had already been filed in other countries. Information disclosed by patents had already been published in industrial property magazines and other media. 
The adoption of the pipeline mechanism extrapolated the obligations contracted internationally before the WTO. Brazil was not obligated to adopt this kind of patent, as the TRIPs Agreement did not demand it.

During this one-year period, 1,182 patent applications were filed in Brazil under the pipeline mechanism.

\section{PIPELINE PATENTS ARE VOID AND UNCONSTITUTIONAL}

When those applications were filed in Brazil, they were already infringing the novelty requirement, since the information was already in public domain and, as such, were part of the state of the art. Those patents, then, could never have been granted, since they did not meet one of the patentability requirements. They are, therefore, invalid patents. ${ }^{337}$

Not only are they invalid, but pipeline patents are also unconstitutional, since they violate the patent clause ${ }^{338}$ determined by the Brazilian Constitution ensuring that the temporary privilege of exploration for industrial creations may only be granted with a view to social interest and the technological and economic development of the country (Article 5, XXIX). ${ }^{339}$

In that regard, according to Professor and jurist Denis Borges Barbosa, the granting of pipeline patents violates the principle of non-withdrawal of the public domain and affronts the vested rights of the society. ${ }^{340}$ Indeed, knowledge that enters the public domain can never be withdrawn from it. Its admission into public domain renders a certain asset a common good and the society is vested with the right of maintaining its availability, preventing its individual appropriation.

\section{Former Minister of Health José Serra Admits: Pipeline patents are unNeCessary and haVe not beEn mandated BY THE WTO TRIPS AGREEMENT}

The then Ministry of Health, Mr. José Serra, at the time of the negotiations of the Patent Act, recognized that: "the introduction of the pipeline mechanism in the Patent Act was an unnecessary concession by Brazil, as it was not a TRIPs demand, and is still a target for criticism."

337 According to Articles 46 and 48 of the Patent Act, the patent that opposes the provisions of the Act is invalid, and its invalidity shall be effective from the date of the patent filing.

338 Barbosa, Denis B. Inconstitucionalidade das patentes pipeline, 2006.

339 See António José Avelã Nunes et al. A inconstitucionalidade das patentes 'pipeline' brasileiras, in Revista Eletrônica do Instituto Brasileiro de Propriedade Intelectual (IBPI), Patentes Pipeline, special edition, November 2009.

340 Idem. 
The adoption of a mechanism such as the pipeline was once proposed by the United States during the negotiation process of the TRIPs Agreement, and was rejected by the other countries for its incompatibility with the international system being created $^{341}$. The WTO itself has spoken up regarding the absence in the TRIPs Agreement of protection to inventions with pipeline patents. ${ }^{342}$

\section{EXAMPLES OF MEDICINES THAT HAVE BEEN PATENTED VIA PIPELINE AND THAT CAUSED SUBTANTIAL PREJUDICE TO BRAZIL}

Some medicines used in AIDS treatment such as Efavirenz, Abacavir, Amprenavir, Lopinavir, Lopinavir/Ritonavir and Nelfinavir were patented through the pipeline mechanism and, therefore, prevented the population and the government from having access to such medicines without having paid royalties to the (supposed) patent holders. medicines for the treatment of cancer, Alzheimer's, Parkinson's and schizophrenia have also been patented by means of the pipeline mechanism, and some of them are included in the Program for Exceptional Medicines, subsidized by the Ministry of Health and managed by the State or Municipal Secretariats of Health Assistance.

Those medicines have taken their toll on the public health system in an absolutely excessive manner by rendering it impossible for the country to acquire cheaper generic versions available in the international market or producing them locally at more accessible prices.

In the case of the medicine Imatinib Mesylate (Glivec $\left.{ }^{\circledR}\right)$ by the company Novartis, used for the treatment of chronic myeloid leukemia, the Brazilian government cannot buy cheaper versions, although there are generic versions commercialized at substantially lower prices in the international market, as this drug is protected in Brazil under a pipeline patent.

The cost per patient/year, of the drug Glivec, paid by the National Health System (SUS) of Brazil and offered in its generic version in India, in 2008, exemplifies the losses generated by pipeline patents for the Brazilian government: US\$29.612,00 (SUS costs) x US\$1.642,00 (cost of generics in India).

341 See lectures by Nuno Pires de CARVALHO, Advisory Director at the Department of Economic Development of the World Intellectual Property Organisation (WIPO) and by Denis BARBOSA, professor at PUC/RJ, in Seminário de Estudos Jurídicos sobre a Propriedade Industrial, Brasília, Conselho da Justiça Federal, 2006. pharma_ato186_e.htm. Acesso em: 14 nov. 2007. 


\section{Damages Caused by pipeline patents}

A technical opinion by the Institute of Economy of the Federal University of Rio de Janeiro (UFRJ) reckons that the losses caused by the adoption of the pipeline mechanism in Brazil for governmental purchases between 2001 and 2007 of five antiretroviral drugs used in the treatment of AIDS were of US\$ 420 or 519 million, compared to WHO or Doctors Without Borders (DWB) prices, respectively (HASENCLEVER et. al., 2010).

Considering that the sums presented in the following graph encompass only the total amount of the purchase of five antiretroviral drugs in the period between 2001 and 2007, and that the number of patents applicationed through the pipeline mechanism, mentioned before, goes up to 1,182 , the same technical opinion by the Institute of Economy of UFRJ estimates that Brazil has had losses of the billion dollar with the granting of pipeline patents (Hasenclever et. al., 2010, p. 177). ${ }^{343}$

\section{Study estimates that the BraZilian PHARMACEUtical INDUSTRY LOST NEARLY US\$ 1 BILLION IN EARNINGS}

In that same regard, a study by Abifina - the Brazilian Association of Chemical and Biotechnology Industries and its Specialties ${ }^{344}$ reveals that, in 2003, the chemical industry, with yearly imports of 7.5 billion dollars, was the chief trigger of the Brazilian commercial deficit, especially the fine chemicals sub-sector, with imports of around 3.5 billion dollars.

The study concludes that, as a consequence, the potential earnings of almost one billion dollars a year are forfeited by the national pharmaceutical-chemical park, a sum that expresses present imports and is five times the total exports, resulting in an elevated deficit in the segment's balance of trade, not to mention the major reduction in highly qualified jobs.

In 2009, the then Attorney-General of the Republic, Antônio Fernando Barros e Silva de Souza, proposed to the Brazilian Supreme Court an ADI concerning Articles 230

343 HASENCLEVER, Lia; LOPES, Rodrigo; CHAVES, Gabriela Costa; REIS, Renata; VIEIRA, Marcela Fogaça. O Instituto de patentes pipeline e o acesso a medicamentos: aspectos econômicos e jurídicos deletérios à economia da saúde. In Revista de Direito Sanitário, São Paulo v. 11, n. 2 p. 164-188, Jul/Oct. 2010.

344 ABIFINA. A indústria farmoquímica no Brasil. Apresentação à Subcomissão Especial de Assistência Farmacêutica e outros Insumos da Comissão de Seguridade Social e Família da Câmara dos Deputados. June 2003. Available at http://www.abifina.org.br/arquivos/abf_publicacoes/A_industria_farmo.pdf. Access: 14 November 2008. 
and 231 of the Patent Act. ${ }^{35}$ The action was filed under the number 4,234 and handed over to Minister Cármen Lúcia Antunes Rocha. The rapporteur Minister determined the application of information to the National congress and to the President of the Republic and, soon after, a review to the Advocate-General and a pronouncement by the Attorney-General.

The respective information and pronouncement were duly served in the case, and reactions were put forth by several civil society, governmental and industry organization, in the quality of amicus curiae ${ }^{346}$. The ADI is still awaiting trial by the Brazilian Supreme Court. If the pipeline mechanism is declared unconstitutional by Brazilian Supreme Court, the technologies protected by pipeline patents will return to public domain in Brazil, since those patents would be considered invalid. Being invalid, technically and legally, their royalties should be returned, since they have been paid for a legally nonexistent object.

\section{THE VIAGRA CASE}

The most publicized case in Brazil was the application for the extension of the Viagra patent. The Brazilian Patent Office managed to overturn the extension of the patent term of its active ingredient: the Second Chamber of the High Court of Justice understood that the patent should be in force until June 2010, and not June 2011, as Pfizer had managed to win in lower courts.

The rapporteur, Justice Mr. João Otávio de Noronha, voted in favor of the appeal filed by the Brazilian Patent Office jointly with the Federal Attorney-General Office, defending the end of the patent term in the original shorter period. Upon his vote, the rapporteur stated that the protection term for pipeline patents such as Viagra should be counted from the first filing abroad, even if it is abandoned, and mentioned the principle of independence of patents to show that the term is not always the same between countries. In the case of Viagra, its first filing was in 1990, in Great Britain, but it was abandoned in favor of a later application.

In March 2012, a legal decision invalidated the patent of lopinavir, one of the active ingredients of the drug Kaletra, owned by Abbott, which is part of the anti-AIDS cocktail offered by the Federal Government. Federal judge Daniela Madeira stated that the patent should not be valid due to lack of examination by ANVISA, the National

345 For a detailed analysis on the main arguments brought in ADI 4234 (Ação Direta de Inconstitucionalidade - Direct Action of Unconstitutionality), see Vieira, Marcela Cristina Fogaça. Proteção patentária para produtos e processos farmacêuticos: a questão da constitucionalidade das patentes pipeline. Paper for the lato sensu Specialization in Intellectual Property Law and the New Information Technologies. Fundação Armando Álvares Penteado - FAAP. 2010.

346 All procedural documents are available for consultation at the Federal Supreme Court website (www.stf. jus.br), under the procedural ADI 4234. 
Sanitary Agency, before its grant by the Patent Office and due to the unconstitutionality of the pipeline mechanism itself.

This patent was granted in 2000, therefore it should have undergone examination by ANVISA. The revalidation through pipeline should be considered unconstitutional for it granted a monopoly to a medicine that was already in the public domain, according to Cristália's attorney challenging the patent.

The adoption of the pipeline mechanism has been rejected by several countries and was declared invalid by the countries that adopted it for its incompatibility with the concept of absolute novelty and the priority principle adopted by international treaties regulating patent rights.

\section{Considerations}

Whereas some patents are in force due to this pipeline mechanism that exists due to a transitional provision in the Brazilian Patent Act, that reaches only patents filed between May 1996 and May 1997, and considering that there is a pending constitutional suit before the Brazilian Supreme Court, challenging the validity of the pipeline mechanism and all patents granted through this mechanism, it rests with the Supreme Court to rule on the constitutionality of the pipeline mechanism and all patents granted through this mechanism.

\section{New Forms of Known Substances and New}

\subsection{New forms of known substances}

\section{Polymorphism}

Polymorphism is the quality of a chemical substance of presenting itself in it solid state in one or more crystalline structures, resulting from the crystallization process itself. In other words, polymorphs are different crystalline forms of the same substance. Each crystalline form is distinct from the original substance (amorphous form) and may or may not have distinct properties, which can be viable for therapeutic use.

Polymorphs are intrinsic properties of molecules and cannot, therefore, be considered a human invention, consisting instead of discoveries. Discoveries are not considered 
inventions and, therefore, are not patentable, in accordance with Article 10, I, of the Patent Act.

Moreover, the search for the most adequate polymorph to improve stability, solubility, bioavailability and processability of the solid form of a certain substance may already be described in the state of the art and, therefore, if that is the case, will not be characterized as non-obvious - one of the essential patentability requirements.

\section{PATENTABility REQUiREMENTS ARE FREelY ESTABLISHED BY EACH COUNTRY'S PUBLIC POLICIES}

The issue of patentability of new uses and polymorphic forms is connected to the interpretation by a given country of the patentability requirements and other criteria provided by law. As already mentioned, the WTO TRIPs Agreements allows members to adopt their own interpretations of the patentability requirements - novelty, nonobviousness and industrial application - as well as the other criteria provided by law. In summary, it is not just a technical decision but, above all, a political decision regarding how Brazil wishes to interpret and apply patentability criteria in the country, with the aim of promoting economic, social and technological development, as established by the Constitutional patent clause (Art. 5, of the Brazilian Constitution).

The new processes for obtaining a new polymorphic form may eventually be patentable, provided they fulfill the requirements of novelty, non-obviousness and best mode. The resulting products, most importantly, are not eligible for patenting according to the arguments mentioned above, but solely the processes.

THE INDIAN SOLUTION: IMPROVEMENT OF KNOWN EFFICACY

India has adopted a path that does not reject polymorph patenting entirely. That country which follows the middle path, deciding that if there is an improvement in the known efficacy of the substance, the resulting product may eventually be patented, if it meets the three patentability requirements, as well as the other two criteria of the social contract established by the patent system - sufficiency of disclosure and best mode.

The patenting of new forms of known substances may result in: (a) the extension of the patent legal monopoly for certain active substances; (b) a delay or difficulty in the introduction of new generic medicines in the Brazilian market; and (c) problems with the access of the population to medicines and treatments, as the extension of patent monopolies keeps prices unduly elevated, resulting in purchasing problems for the National Health System (SUS). Thus, the granting of trivial patents can introduce 
serious hindrances to the politics of innovation and technological modernization in course, in addition to directly harming accessibility to medicines and important agricultural materials such as crop protection chemicals and seeds.

\section{Argentina, Brazil, Chile, Paraguay and Uruguay adopt measure TO AVOID NEGATIVE IMPACT ON ACCESS TO MEDICINES}

Brazil is not the only one beginning to realize that those kinds of inadequate patenting attempts are harmful to health and to technological, economic and social development; but also the Ministries of Health of Chile, Argentina, Uruguay and Paraguay, which, along with the Brazilian Ministry of Health, have signed the Agreement "Patentability Criteria, Access to Medicines and Public Health" as it is their understanding that

the fulfillment and application of the patentability criteria in our region raises concerns due to the proliferation of patent applications on matters that do not properly constitute an invention or are marginal developments. These difficulties have been highlighted in several studies evidencing the negative effects to access to medicines and public health in the granting of patents for medicines based on these types of claims. ${ }^{347}$

This is the understanding sanctioned by the World Health Organization - WHO on the Guidelines for the examination of pharmaceutical patents: developing a public health perspective, elaborated by Dr. Carlos Correa, Professor at the University of Buenos Aires (CORREA, 2007, p. 10-11).

\section{The Ritonavir CASe}

The example of the antiretroviral drug Ritonavir, which is in public domain in Brazil, shows us in practice the effects of polymorph patents. There are patent applications for polymorphs of the Ritonavir active principle that, if granted, would hinder the production of the corresponding generic medicines.

\section{GRANTING PATENTS TO NEW FORMS OF KNOWN SUBSTANCES, WITHOUT IMPROVEMENT OF KNOWN EFFICACY, IS DETRIMENTAL TO BRAZIL}

The line of reasoning that defends that the national industry could be harmed in case polymorph patents are not allowed is used with a certain frequency. Those who defend this argument maintain that developing countries (Brazil included) should only be 
holders of incremental patents, considering our still limited capacity for innovation. However, it is worth stressing that, if the granting of polymorph patents was technically possible, they would only be granted to the holder of the first patent, as other patents would constitute an infringement of the original patent by being actually the same substance only with a different arrangement.

Thus, even if there was any kind of advantage for the encouragement of national industrialization in patenting new forms of known substances, if this kind of patenting was authorized, it would only bring about the consolidation of the legal monopoly of companies that already hold patents for amorphous substances; most of them transnational companies.

In the United States, the Federal Trade Commission has been criticizing their Patent Office for not paying due attention to the issue of new forms of known substances and, consequently, adopting weak patentability criteria that result in anti-competition consequences. $^{348}$

According to this reasoning, the Brazilian Association of Chemical and Biotechnology Industries and its Specialties (Abifina) ${ }^{349}$ has been adopting the opposite attitude towards the patenting of new forms of known substances by understanding that those patents do not meet the requirements of novelty and non-obviousness. Accordingly, the Oswaldo Cruz Foundation (FIOCRUZ) as well as ANVISA have also adopted a contrary position towards the patenting of new forms of known substances. ${ }^{350}$

\subsection{New uses}

The second medical use (which can include a third, fourth or fifth use, and so on) constitutes a new therapeutic application of a new compound that already has a therapeutic use.

\section{New uses are mere discoveries}

New uses of a known product are, in reality, discoveries of a new effect of this product, given that nothing has been altered in the product; there is no sense in talking of a new invention, but only a new use for an existing invention, and new discoveries are not patentable according to the Patent Act (Art. 10, I).

348 Federal Trade Commission (FTC). To promote innovation: the proper balance of competition and patent law policy. 2003.

349 Abifina, Comitê de Propriedade Industrial, Patenteabilidade de polimorfos. 2007.

350 See participation in the cycle of technical discussions conducted by the Brazilian Patent Office. Available at: https://www.inpi.gov.br/menu-esquerdo/patente/discussoes-tecnicas/index_html/. Access: 3 April 2011. 


\section{NEW USE PATENTS AFFRONT FREE COMPETITION}

The new use patent becomes a mechanism to inadequately and illegally extend a patent term for a reference medicine.

From the moment the 20-year term of the patent of a reference or innovative drug ends, the right guaranteed by TRIPs comes into force, which allows other pharmaceutical companies to enjoy the possibility of manufacturing and commercializing the product with an expired term that can therefore be commercialized such as, for instance, the generic medication.

Companies that are patent holders of reference or innovative medicines, with the aim of keeping the commercial monopoly of the product and/or making the introduction of competition more difficult, application the granting of patents for new processes of synthesis, new forms of known substances, pharmaceutical compound, second medical use and so on, seeking to appropriate the technology regarding that medication - in clear dishonor of competition principles.

\section{Report by the Government of the United Kingdom WARNS AGAINST THE PATENTING OF NEW USES}

The CIPR Report by the Government of the United Kingdom is clear: “[...] we caution against developing countries simply taking over from the comparatively recent European jurisprudence the counter-intuitive notion that a product may be regarded as new, if a new use is identified for it. Such an approach is not required by TRIPS [...]."351

\section{NEW USES ARE MERE THERAPEUTIC METHODS}

The claim for a new use patent is aimed at protecting the effect of the compound in the organism and not the product in itself or its manufacturing methods. In that sense, such claims are substantially equivalent to claims to treatments or therapeutic methods, which are expressly excluded from patenting in accordance to the Art. 10 VIII of the Patent Act.

This is the understanding sanctioned by the World Health Organization - WHO, already mentioned in the Guidelines for the examination of pharmaceutical patents: developing a public health perspective elaborated by Dr. Carlos Correa, Professor at the University of Buenos Aires. 
Whether it is for their status as discoveries and therapeutic methods or for their noncompliance with the novelty or industrial application requirements, patents of use and new use must not be protected as new inventions. Admitting their patentability means unduly extending protection to cases in which nothing new has been developed, which favors the patent holder to the detriment of competition and the national public interest, in direct confrontation of the Brazilian Constitution (Art. 5, XXIX).

By unduly extending the temporary legal monopoly of a previous patent, the new use patent hinders the production of generic medicines, harming the population and the federal, state and municipal bodies in charge of the free distribution of those medicines. They would also pose a threat to companies waiting for the patent to come to term in order to enter the generic market for that medicine. All to the detriment of public health, competition laws, as well as the goals of the patent system provided by the Brazilian Constitution.

\section{"ONe SIZE does nOt FIT ALL:}

DIFFERENT TREATMENTS ARE THE PRINCIPLE OF JUSTICE"

It becomes evident that the most advanced countries in the chemical field are nowadays issuing second medical use patents one way or the other, since they already have sufficient knowledge in the area. We see fit to remember, however, that many of those countries were not even protecting pharmaceutical products until recently, when they did not yet have technological ability in the chemical field. It was not until their capacitation in the chemical field that they began to change their laws to appropriate those new uses. In fact, some countries such as Holland even abolished their patent system entirely as they understood that it was detrimental to their economy. 352

The one size does not fit all motto reminds us that a certain regulation, for a certain country, will not necessarily be beneficial to another country, especially if they have different degrees of development in the area under comparison. Thus, Brazil should not adopt similar regulations to other countries, if our technological development in a certain area is not sufficiently advance to result in more social and economic benefits than losses to the country.

Thus, processes of copy and imitation, in case Brazil is not internationally obligated to adopt a certain regulation (such as issuing new use patents, for instance), are essential to the development of technological ability, with resulting social and economic benefits for

352 The Netherlands abolished its patent system entirely from 1869 to 1910 . See Adam B. JAFFE and Josh LERNER, Innovation and Its Discontents - How our Broken Patent System is Endangering Innovation and Progress, and What to Do About it. Princeton, 2004, pp. 86-90. 
the country. In fact, it was through copy and imitation that countries that are presently developed manage to evolve.

In that regard, the Gowers Review by the Government of the United Kingdom is emphatic: "The economic evidence and, in particular, the history of currently developed countries suggest that a single one-size-fits-all approach is inappropriate. (...) Given that different IP regimes are more appropriate at different stages of development, it would make sense to allow individual nations to choose when to strengthen their IP regimes, rather than to seek to enforce a certain perspective."

\section{The granting of new use patents contradicts the Mercosur Ministers of Health Agreement, the WTO Doha Declaration and the WhO Resolution}

The facilitated granting of polymorph and new use patents goes against the Agreement between Mercosur Ministers of Health, ${ }^{353}$ as mentioned above, as well as the text of the Doha Declaration on the TRIPs Agreement and Public Health, produced in the WTO's ministerial conference of 2001. Similarly, the World Health Organization resolution WHA61.21, approved at the 61 ${ }^{\text {st }}$ World Health Assembly contemplates the principles by which the intellectual property rights cannot and must not hinder member countries from taking measures for the promotion of public health, which would be directly challenged in case of inappropriate extension of the term or legal monopoly of a chemical substance of importance to public health.

\section{ARgentinA'S PATENT GUIDELINES}

Argentina, in accordance to the understanding adopted by Mercosur and other multilateral bodies mentioned above, has altered, in May 2012, their guidelines for patent examination in the chemical-pharmaceutical field. ${ }^{354}$ Concerning new uses, those are considered treatment methods, and, therefore, are not eligible for patenting. The same understanding is adopted in regard to new dosages and combinations. As for polymorphs (as well as pseudo-polymorphs - hydrates and solvates), the new guidelines exclude the possibility of patenting by not considering them new inventions, since they are intrinsic properties of matter - therefore, mere discoveries. They also exclude the possibility of patenting processes for obtaining new forms of known substances, as they constitute routine experiments in the field.

The new Argentinian guidelines also encompass other forms of variations of a single substance such as salts, esters, amides, enantiomers and other derivatives, excluding

353 See MERCOSUR, Reunião de Ministros da Saúde (MERCOSUR/RMS/ACORDO No 09/09).

354 Available at http://www.inpi.gov.ar/templates/novedades/res118-546-107.pdf. 
the possibility of patenting as the substance is already known. New formulations and compounds are also excluded from patentability as they are considered obvious and, therefore, do not meet the non-obviousness requirement.

\subsection{The Brazilian Patent Office's examination guidelines, and the decision of the Inter-ministerial Group on Intellectual Property}

The Guidelines for the examination of patent applications in the biotechnology and pharmaceutical fields filed before 31 December 1994 of the Brazilian Patent Office INPI do admit the granting of polymorph and claim to use patents, especially through a legal artifice forged in Europe known as "Swiss claim". 355 By this device, use patents are made equal to process patents.

In regard to new forms of known substances, the guidelines presently in force are remiss, but the Brazilian Patent Office has been accepting the granting of patents for new crystalline forms. ${ }^{356}$

In June 2007, the Brazilian Patent Office organized a cycle of technical debates aimed at discussing the patentability conditions of new forms of known substances to support the new examination guidelines in the pharmaceutical field.

By means of the new proposed examination guidelines, the Brazilian Patent Office considers that new forms of known substances may have novelty and non-obviousness, as long as they meet certain criteria. They also consider that some pharmaceutical compounds that present new forms of known substances may be eligible for patenting. The guidelines also make possible the granting of patents for new processes for obtaining new forms of known substances.

It is paradoxical for the Brazilian Patent Office to consider that new forms of known substances meet the non-obviousness criterion while the CIPR Report by the Government of the United Kingdom clarifies that, when the standard for non-obviousness is low and, for instance, allows the patenting of new forms of known substances, if applied to developing countries, this standard becomes detrimental to research. And the same study goes on to recommend measures to developing countries such as Brazil: "The

355 Fórmula suíça ou "swiss claim" é a reivindicação do uso de um composto farmacêutico conhecido, para a produção de composições farmacêuticas nas quais o composto apresenta atividade terapêutica anteriormente desconhecida. A reivindicação é feita de uma forma que abarque a descoberta de um uso médico subsequente, de uma substância conhecida. A "aspirina" é um exemplo clássico: foi primeiramente comercializada como analgésico, mas depois se descobriu que possui, também, propriedades de depuração do sangue. See Feroz Ali Khader, "The Law of Patents - With a Special Focus on Pharmaceuticals in India", LexisNexis Butterworths, 2007, p. 76.

356 Soares, Jaqueline Mendes et al. op. cit. p. 47. 
objective of any standard should be to ensure that routine increments to knowledge, involving minimal creative input, should not generally be patentable."357

\section{THE BRAZILIAN INTER-MINISTERIAL GROUP ON INTELLECTUAL PROPERTY ISSUEd A RESOlUtion AgAinst the PATENTING OF NEW USES AND NEW FORMS OF KNOWN SUBSTANCES}

Considering the different views and the importance of the theme for the social, economic and technological development in the country, the Inter-ministerial Group on Intellectual Property ${ }^{358}$, which is the organism in charge of harmonizing the positions of the Federal Executive Branch and its bodies about patent and related rights, has issued a decision in December 2008 expressing a position by the Federal Government contrary to the extension of patent protection to new uses and new forms of known substances. the Brazilian Patent Office, however, expressed that, in case such impediments came into force, an alteration in the Patent Act would prove necessary so that they could be contemplated.

Strictly speaking, there would not be the need for law alterations to prevent new use and polymorph patents from being granted. However, keeping in mind the position adopted by the Brazilian Patent Office making possible the granting of those patents, even going against the Federal Government's decision, which is expressly contrary to those patents, as conveyed by the Inter-ministerial Group on Intellectual Property, we understand that an alteration in the legislation can prove enlightening.

\section{Recommendations}

\section{a) To Congress:}

Approve Bill H.R. 5402/2013 in order not to allow (i) patents for new forms of known substances that do not result in the improvement of the known efficacy of the substance, for they are mere discoveries and lack inventive step, and (ii) patents that claim any new property or new use of a known substance, for they are mere discoveries, lack novelty and industrial application, and for they are mere therapeutic methods, in order to promote greater legal certainty and to respect the Constitutional patent clause (see Art. 3 of Bill 5402/2013, attached, that amends Art. 10 of the Patent Act).

357 See UNITED KINGDOM, Commission on Intellectual Property Rights (CIPR), Integrating Intellectual Property Rights and Development Policy, London, 2002.

358 MDIC. Inter-ministerial Group on Intellectual Property (Grupo Interministerial de Propriedade Intelectual) publishes summary of meeting minute. December 19, 2008. Available at: http://www.mdic.gov.br/arquivos/ dwnl_1229696044.pdf. Access: April 11, 2011. 


\section{b) To the Executive Branch:}

Immediately implement the Inter-ministerial Group on Intellectual Property (GIPI) resolution mentioned in this chapter in order to tackle the issue appropriately and to eliminate the present legal uncertainty.

\section{b.2) to the Brazilian Patent Office (INPI):}

b.2.1) reject patents for new forms of known substances that do not result in the improvement of the know efficacy of the substance, as they are mere discoveries and lack inventive step;

b.2.2) reject patents that claim any new property or new use of a known substance (second and further uses), as they are mere discoveries, lack novelty and industrial application, besides being mere therapeutic methods; and

b.2.3) clearly indicate in the examination guidelines that it shall not be patentable (a) any new properties or uses of a known substance, as well as (b) new forms of known substances provided the latter do not result in improvement of the known efficacy of the substance.

\section{b.3) to the Sanitary Agency - ANVISA:}

Duly observe, in the prior consent procedures, the three patentability requirements, as well as the other two criteria established by the patent system sufficiency of disclosure (enablement) and best mode.

\section{b.4) to the Competition Agency - CADE:}

Tackle anti-competitive and abusive practices caused by patents claiming any new properties or uses of a known substance, as well as new forms of known substances that do not result in the improvement of the substance's known efficacy. ${ }^{359}$

\section{The sanitary agency's (ANVISA) prior consent}

For a patent in the pharmaceutical field to be granted in Brazil, it must first get prior consent from the National Agency of Sanitary Surveillance (Agência Nacional de Vigilância Sanitária - ANVISA), first by means of the Provisional Act, and then through the Patent Act. However, some issues arose regarding ANVISA's role in the exercise of previous consent, which has been weakening this institute of protection of public health 
and the development of the country. We believe that some alterations in the legislation can help eliminate any remaining doubts as well as strengthen ANVISA's participation in the process of examining patents to the benefit of social, economic and technology development in Brazil.

It became mandatory for pharmaceutical patent applications to undergo analysis by ANVISA ever since the institution of Provisional Act 2.006/1999, which created the legal figure of prior consent. Prior consent was consolidated by Act 10.196, of 2001, which altered the Article 229 of the Patent Act - including Paragraph C:

Article 229-C, Patent Act

The granting of patents for pharmaceutical products and processes depends on the prior consent of the National Agency of Sanitary Surveillance - ANVISA.

ANVISA's prior consent is a measure to protect public health and is in perfect accordance to the international patent rules. This measure is corroborated by the principles of the TRIPs agreement established in Articles 1 and $8^{360}$ and the WTO's dispute settlement organism has already confirmed that countries are allowed to institute differentiated mechanisms of analysis of patent applications in certain fields, in order to implement national policies, and that it is not characterized as violation to the non-discrimination principle feature in Article 27 of TRIPs. ${ }^{361}$

\section{ANVISA RESOLUTION (RDC N $\left.{ }^{\circ} 45 / 2008\right)$}

By adopting this system, patent examination in the pharmaceutical field is now guided by the following steps: a) the Brazilian Patent Office receives and examines a patent application; b) if the Brazilian Patent Office determines that the patent should not be granted, then it is rejected; c) if the Brazilian Patent Office judges that the patent should be granted, then it is passed to ANVISA where it undergoes a second assessment; d) ANVISA examines the application and the Brazilian Patent Office's decision, often applicationing additional material from the patent office and the applicants; e) ANVISA may deny or grant its prior consent to the patent, but even when it grants prior consent

360 TRIPs Agreement, Article 1. Members shall give effect to the provisions of this Agreement. Members may, but shall not be obliged to, implement in their law more extensive protection than is required by this Agreement, provided that such protection does not contravene the provisions of this Agreement. Members shall be free to determine the appropriate method of implementing the provisions of this Agreement within their own legal system and practice. Article 8 - Principles - 1-Members may, in formulating or amending their laws and regulations, adopt measures necessary to protect public health and nutrition, and to promote the public interest in sectors of vital importance to their socio-economic and technological development, provided that such measures are consistent with the provisions of this Agreement.

361 WORLD TRADE ORGANIZATION. WT/DS114/R, March 17, 2000, paragraph 7.92. Beyond that, it is not true that Article 27 requires all Article 30 exceptions to be applied to all products. Article 27 prohibits only discrimination as to the place of invention, the field of technology, and whether products are imported or produced locally. Article 27 does not prohibit bona fide exceptions to deal with problems that may exist only in certain product areas. Available at www.wto.org/english/tratop_e/dispu_e/7428d.pdf. 
it may do so only after requiring that the applicant narrow some of the patent's claims; f) ANVISA's report is returned to the Brazilian Patent Office, which can formally grant the patent only if ANVISA has given its prior consent (SHADLEN, 2011).

Prior consent has, since then, caused tension between the institutions involved in the examination of patents and other interested parties. Ever since its adoption, several patent grants issued by the Brazilian Patent Office have been denied by ANVISA. In addition, among the granted patent, many had some of their rights granted by the Brazilian Patent Office restricted. Moreover, several granted patent applications had to provide better descriptions of the inventions so that the report was as complete as it could be, in accordance to the demands of the Patent Act in force (Art. 25).

The Brazilian Patent Office understands that they have exclusive competency to analyze the three patentability requirements, as well as two other social contract criteria established by the patent system - sufficiency of disclosure and best mode; and that, therefore, ANVISA should not, in their prior consent examination, evaluate whether those requirements had been fulfilled. According to the Brazilian Patent Office, ANVISA should focus on analyzing eventual risks to public health only.

ANVISA, on the other hand, has been holding on to the understanding that their analysis of possible risks to public health has to be done while observing the patentability criteria and the other necessary legal criteria for a legitimate patent system. Patents that do not have novelty or non-obviousness (two of the patentability requirements), or that act against national public health by not having sufficiency of disclosure in its claims for the reproduction of product or process in situations of national emergency or government use, for instance, would put public health at risk and thus, according to ANVISA, those requirements should be part of their criteria when undertaking prior consent examinations.

By the end of the 2000's, the Brazilian Patent Office no longer recognized ANVISA's role in patent examination through administrative, legal and legislative channels by considering that ANVISA's role was to deal only with matters concerning health but not with patentability criteria.

In several moments, additional information about filed patents required by ANVISA were not supplied by the Brazilian Patent Office, hindering the continuity of the examination by the Agency. In the cases of denied prior consent, the Brazilian Patent Office adopted a position of not denying the patent application but freezing it instead with the goal of making time to wait for the end of ANVISA's power over this examination $^{362}$ (SHADLEN, 2011). 
Many attorneys with foreign clients, the multinational pharmaceutical industry as well as the Brazilian Patent Office understand that ANVISA must not examine the three patentability requirements or the other two social contract criteria established by the patent system - sufficiency of disclosure and best mode. The World Health Organization (WTO), as well as other human rights advocates, on the other hand, are for a more extensive participation by ANVISA. The CIPR Report by the Government of the United Kingdom also understands that ANVISA “[...] may be in a better position to comment on, for example, the inventiveness of the claimed invention." ${ }^{363}$

\section{Decision of the Inter-Ministerial Group on Intellectual Property (GIPI)}

In December 2008, the Inter-ministerial Group on Intellectual Property (GIPI) declared a consensual position against the granting of patents for incremental pharmaceutical innovations. In that context, this declaration supported the presuppositions of ANVISA's examination. the Brazilian Patent Office, however, dismissed GIPI's resolution, declaring that they would not change their examination practices without an alteration on the Act itself (SHADLEN, 2011).

\subsection{Prior Consent: The Legal Debate}

To Denis Barbosa (2009), prior consent is constitutional. The author cites Basso (2006), for whom, in the Brazilian Constitution, there is nothing appointing the Brazilian Patent Office as the only legitimate body for the examination of patent claims, which does not configure illegal activity in its shared function with ANVISA.

Carvalho (2002) clarifies that members of the WTO may bestow the responsibility of examining inventions to different agencies according to their fields of expertise.

For each ANVISA denial, the Judicial Branch saw the appearance of demands questioning the role of the Sanitary Autarchy.

In the administrative sphere, the Brazilian Patent Office initiated a formal investigation at the Office of the Attorney-General (Advocacia-Geral da União - AGU), that issued in 2009 the Opinion 210/PGF/AE/2009. 


\section{UNDERSTANDING THE PRIOR CONSENT CASE: history of opinions by the OfFice of the Attorney-General}

The understanding of the Office of the Attorney-General is that it is not ANVISA's attribution to analyze the three patentability requirements, as that would be an attribution of the Brazilian Patent Office. ANVISA's role in the exercise of prior consent, according to the issued opinion, should be limited to the analysis of the harmful potential of the product towards human health.

At the time, ANVISA, the Minister of Health and the Minister of Science and Technology $y^{364}$, along with civil society groups ${ }^{365}$, as well as other actors, required the review of Opinion no. 210/PGF/AE/2009.

AGU, however, confirmed their prior decision, by means of Opinion 337/PGF/ EA/2010 366 , published in January 2011. The new opinion did not accept the application for a review and went further in stating that ANVISA's prior consent should be limited to the mere presentation of inputs for the examination, which the Brazilian Patent Office could take into account or not.

The Opinion mentioned above has been highly criticized by some sectors, as it ignores the law. Article 229-C of the Patent Act determines that the "granting of patents for pharmaceutical products and processes depends on prior consent by ANVISA". "Depend" does not mean merely to consider, but that the patent application cannot be granted if there is no prior consent. Moreover, any interested party may put forth "inputs" to examination, in accordance to Article 31 of the Patent Act and, therefore, that must not have been what the legislator aimed for.

The harmfulness of a pharmaceutical product is weighed by ANVISA when a sanitary record is required for its commercialization, when all necessary studies to back this analysis are produced. This examination of harmfulness to health happens at a later stage, after the patent is granted. And it is already mandatory by law. Sanitary record has nothing to do with patent and, therefore, it makes no sense for the legislator to institute a new mechanism in the Patent Act for ANVISA to undertake the same analysis it would have otherwise undertaken at a later time, and with the same propriety.

In that context, it would be impossible for ANVISA experts to analyze the harmfulness of a product to human health with only the information contained in a patent application.

364 ESTADO DE SÃO PAULO. Ministérios da Saúde e de Ciência e Tecnologia intervêm por ANVISA no caso de patentes, 12 de agosto de 2010. Available at http://www.estadao.com.br/estadaodehoje/20100812/ not_imp593908,0.php.

365 Letter to the Federal Attorney General, Mr. Marcelo Siqueira, requiring that ANVISA maintains prior consent. Available at: http://www.petitiononline.com/gtpi2/petition.html.

366 AGU. Case no. 00407.005325/2007-71. Available athttp://www.agu.gov.br/sistemas/site/TemplatelmagemTextoThumb.aspx?idConteudo=153676\&id_site $=3$. 
That is because there are several typed of patent applications in the pharmaceutical sector, encompassing different phases of development of a medicine. For instance, protection can be applicationed for a compound with activity toward a certain disease without the realization of clinical tests and, even then, the invention may observe the three patentability requirements.

That is the understanding being put forth by ANVISA's examiners themselves while trying to apply legal decisions ${ }^{367}$ which, following the AGU orientations, determine that prior consent be limited to analyzing the risks for human health. In their own words ${ }^{368}$ :

the application for such verification in patent rights is new, and, due to the peculiarities that characterize an administrative process of invention application, it brings difficulties to the examiner that undertakes it, as, naturally, an invention application does not contain enough elements for the realization of an analysis of harmfulness to the human health.

And $^{369}$ :

Given that the characteristics of a patent application's text are regulated by administrative acts of the Brazilian Patent Office and the characteristics of the text of a application for registration of medicines are regulated by ANVISA, one can reach the conclusion that the analysis of prior consent based on weighing public health motivations, notably sanitary risk, renders all patent objects in the field of pharmaceutical products and processes carriers of potential immeasurable risk, as information considered fundamental for the analysis of an invention application differs from information necessary for the evaluation of sanitary risk.

In other opinion ${ }^{370}$ that reached the same conclusion:

The analysis of sanitary risk of a product (medicine) is a procedure that involves its own routine and depends on defined conditions and parameters by its constituents.

The analyzed invention application, therefore, does not hold all information necessary to weigh on the quality, safety or efficacy of the claimed object,

367 Court decision in the case file No. 2009.34.00.037368-5, 5th Federal Court of the Federal District Judiciary Section.

368 ANVISA, Parecer técnico de formulação de ciência a pedido de patente de produtos e processos farmacêuticos. Opinion no. 230/10/COOPI/GADIP/ANVISA. 10 December 2010. p. 1.

369 Idem. p. 1.

370 ANVISA, Parecer técnico de formulação de ciência a pedido de patente de produtos e processos farmacêuticos. Opinion no. 250/2010/COOPI/GADIP/ANVISA, of 19 November 2010, p. 6. Opinion prepared in compliance with the judicial decision in the case file No. 2009.34.00.037369-9. 
reason by which it would be technically impossible for ANVISA to examine such requirements in the moment of the prior consent examination.

\section{Non-exclusive competency by the Brazilian Patent Office}

There is no law attributing the examination of patent applications and the observation of patentability requirements exclusively to the Brazilian Patent Office, or of the two other social contract criteria established by the patent system - sufficiency of disclosure and best mode. In the Brazilian Constitution, there is nothing determining which organism is responsible for the examination and granting of patents in Brazil. There are no grounds, therefore, to talk about exclusive competency by the Brazilian Patent Office.

the Brazilian Patent Office's leading attribution is the put into practice the norms regulating industrial property ${ }^{371}$, which does not mean that this is an attribution exclusive to the Autarchy. In fact, no law attributes to the Brazilian Patent Office the exclusive competency to examine and grant patent applications; not its founding act Act $n^{\circ} 5.648 / 70$ - nor the Patent Act.

The Patent Act ${ }^{372}$ only determines that patent applications follow the conditions established by the Brazilian Patent Office, which must undertake a preliminary examination about the observation of such conditions, but nowhere does the law provide that the Brazilian Patent Office must be responsible, least of all the sole responsible for the technical examination and granting of such applications.

The WTO's TRIPs Agreement, in its Article 1.173, establishes that countries may freely determine the appropriate way to implement the provisions of the Agreement in the scope of their own legal systems and practices. Nuno Pires de Carvalho explains ${ }^{374}$ :

371 Act No. 5.648/70, Article 2. the Brazilian Patent Office has as its main purpose to execute nationwide the rules that regulate industrial property, in view of its social, economic, legal and technical roles, as well as give its opinion on the convenience of signature, ratification and denunciation of conventions, treaties, covenants and agreements on industrial property.

372 Industrial Property Act, Article 19 - A patent application, in accordance with the conditions established by the Brazilian Patent Office, will contain: I- a application; II - a specification; III - claims; IV - drawings, if any; $\mathrm{V}$ - an abstract; and VI - proof of payment of the filing fee.

Industrial Property Act, Article 20 - Once presented, the application will be submitted to a formal preliminary examination and, if in due order, will be protocolled, the date of presentation being considered as the filing date. Industrial Property Act Act, Article 21 - An application that does not formally meet the requirements of article 19, but which does contain data relating to the subject matter, the applicant and the inventor, may be delivered to the Brazilian Patent Office against a dated receipt which will establish the requirements to be met within a period of 30 (thirty) days, on pain of return or shelving of the documentation. Sole Paragraph Once the requirements have been met, filing will be considered to have been made on the date of the receipt.

373 TRIPs Agreement. Article 1. Nature and Scope of Obligations. 1. Members shall give effect to the provisions of this Agreement. Members may, but shall not be obliged to, implement in their law more extensive protection than is required by this Agreement, provided that such protection does not contravene the provisions of this Agreement. Members shall be free to determine the appropriate method of implementing the provisions of this Agreement within their own legal system and practice.

374 CARVALHO, Nunes Pires. The TRIPs regime of patents rights. Kluwer Law International: The Hague, 2002. p. 161. 
A WTO member may also confer the authority to carry out the substantive examination of inventions to various agencies according to their expertise. The Paris Convention (Article 12) refers to a central office for the purposes of communication to the public of patents, not to examine them.

International rules, therefore, do not stipulate which organism must be in charge of the examination of patent applications nor even establish that only one organism must fulfill that role. Countries may, at their discretion, attribute the examination of patent rights to the organisms they deem more appropriate according to their national policies.

The Brazilian Constitution does not establish which is the organism responsible for the examination of patents, leaving that attribution for the Patent Act. There is no law establishing that the patent examination, - and, therefore the analysis of the three patentability requirements, and the other criteria established by the patent law: sufficiency of disclosure and best mode - are the Brazilian Patent Office's attribution and much less, the exclusive attribution of that Office.

The Patent Act, in determining that the granting of pharmaceutical patents depended on prior consent by ANVISA, attributed to them the power/duty to analyze all requirements fixed by law for the examination of a patent - including the patentability requirement and other criteria established by law.

\subsubsection{The public class action, and the complaint to the UN}

A public class action was filed against the AGU Opinion (46656-49.2011.4.01.3400) by the Federal Prosecutor Office, with the following order of merit: i) the declaration of invalidity of Opinion 210/2009; ii) the recognition of the power/duty set forth by Article 229-C of the Patent Act to ANVISA, for the analysis of the patentability requirements for patent applications for pharmaceutical products and processes in course at the Brazilian Patent Office; and iii) the declaration of the automatic application of the provision of the mentioned Article 229-C, rejecting any understanding to the contrary.

Organizations of the civil society advocating for human rights filed a complaint to the UN Special Rapporteur towards the human right to health against the AGU's interpretation of ANVISA's role in the exercise of prior consent, arguing that it consisted of a regress in the protection to the right to health and was contrary to the obligation contracted with the UN of adopting all available measures for the actualization of the 
right to health in Brazil ${ }^{375}$. The complaint follows the regular procedures within the United Nations' framework.

\subsubsection{Grupo de Trabalho Interministerial}

An Inter-ministerial Working Group (Grupo de Trabalho Interministerial - GTI) was created to harmonize the theme, with the participation of the Ministry of Health (MS), the Ministry of Development, Industry and Foreign Trade (MDIC), AGU, ANVISA and the Brazilian Patent Office. The initial results of this effort are embodied by the Inter-ministerial Ordinance no. 1.065, of 24 May 2012, and in the final report produced by the GTI.

The Ministry of Science, Technology and Innovation, the Ministry of Foreign Affairs and the Ministry of Justice did not take part in the Group. If they did, the result would most probably be different, more balanced, as it would involve more field experts and agents of the Brazilian State.

The GTI report highlights that the participation of ANVISA must necessarily occur by means of previous analysis by the Brazilian Patent Office, considering their technicalscientific capacitation and based in pertinent and relevant criteria to prior consent, with the aim of evaluating the impact of the pharmaceutical product or process with a view towards public health.

\subsubsection{ANVISA's Public Consultation no. 66/2012}

In 24 October 2012, ANVISA initiated the Public Consultation no. 66/2012, with the duration of 60 days, to collect society's contributions regarding applications for pharmaceutical patents and the relationship between ANVISA and the Brazilian Patent Office over the matter of prior consent. The public consultation proposed the alteration of RDC 45/2008, that sets forth the administrative procedure regarding ANVISA's prior consent for the granting of patents for pharmaceutical products and processes.

ANVISA proposes a new resolution, stating clearly that it will examine the patentability requirements, as well as the other criteria provided in the Patent Act.

375 The full text of the complaint made by Brazilian society organizations against the interpretation of Article 229-C of the Patent Act, conferred by the National Attorney General (AGU), sent to the UN Special Rapporteur for the human right to health is available at: http://www.patentes.org.br/media/file/Urgent\%20 appeal\%20against\%20Brazil\%20-\%20by\%20GTPI\%20\%28with\%20annexes\%29.pdf. 


\subsection{Restriction to the patent applications under the pipeline mechanism}

Another proposal ${ }^{376}$ has been discussed about the role of ANVISA in the examination process of pharmaceutical patents: that prior consent could only prove necessary for patent applications filed under the mechanism known as pipeline. ${ }^{377}$

Pipeline patents are provided in the Articles 230 and 231 of the Patent Act. By means of this mechanism, the filing of patent applications in technological fields of expertise for which Brazil did not previously issue patents (mainly medicines and food) until 2006 (date of publication of the Patent Act) was made possible. The filing of a patent application through the pipeline mechanism was accepted only for the duration of one year, between May 19966 and May 1997. Pipeline patents would "revalidate" nationally the patents of medicines, foods and chemical-pharmaceutical products and processes issued abroad without undergoing technical examination of patentability requirements by the Brazilian Patent Office.

Pipeline patents could only be filed for a certain period. Therefore, by linking ANVISA's prior consent to those types of applications only, prior consent would also only be valid for a certain period, becoming extinct after the examination of patents filed through the pipeline mechanism.

Those who advocate in favor of this limitation of prior consent employ as argument the fact that the Article 229-C, which instituted the mechanism, is located under the title "transitory and final provisions" of the Patent Act. This was the argument used by the Brazilian Patent Office when applicationing a review by the AGU regarding the time span of the prior consent (Opinion no. 337/PGF/EA/2010, p.2). In 2009, AGU issued an opinion that, among other things, stated that prior consent should apply to all pharmaceutical patent applications, not only pipeline, a position that was confirmed by AGU in 2010, after the application for reconsideration of their opinion.

Despite the fact that the article which included prior consent was located under the transitory and final provisions title, that, in itself, does not imply that it is also a transitional provision. Other articles included in the same chapter also have permanent character. Article 240, for instance, which establishes the purpose of the Brazilian Patent Office, and Article 24l, authorizing the creation of special intellectual property courts, are not mere transitional provisions, despite being included under this title.

376 Bill No. 3.709/08, by Congressman Rafael Guerra (PSDB/MG), and the Bill No. 7.965/10, by Congressman Moreira Mendes (PPS/RO) deal with the subject and are being discussed jointly at the Chamber of Deputies.

377 For more information on pipeline, see Chapter 6 of this Report and the Direct Action of Unconstitutionality - ADI 4234 (or Ação Direta de Inconstitucionalidade), proposed by the Federal Attorney General from represented civil society organizations challenging the constitutionality of the mechanism. The written application of the action, opinions of authorities and documents sent by different civil society actors on the topic can be found on the website of the Federal Supreme Court: www.stf.jus.br 
In order to avoid biased interpretation, we propose a legislative alteration aimed at making evident that ANVISA's prior consent is applicable to all types of patent applications in the pharmaceutical field and not just those filed under the pipeline mechanism.

\subsection{ANVISA's prior consent and its relevance to public health}

Between 2001 and 2009 (until October), ANVISA analyzed 1,346 patent applications. Out of those applications: i) 988 were granted consent; ii) 119 were denied consent; iii) 90 were barred by the Brazilian Patent Office after ANVISA's examination and iv) 149 were in other situations as of the conclusion of the study (such as waiting for ANVISA's examination or for the fulfillment of requirements by the applicant). The main reasons for denial of consent by ANVISA are shown in the following table.

Table 10 Reasons for denial of prior consent by ANVISA (2001 a 2009)

\begin{tabular}{|lrr|}
\hline Main reason for denial of prior consent & $\mathbf{n .}$ & $\%$ \\
\hline Absence of novelty (total or partial) & 57 & $47.9 \%$ \\
\hline Absence of inventive activity (non-obviousness) & 27 & $22.7 \%$ \\
\hline Insufficiency of disclosure & 19 & $16 \%$ \\
\hline Natural product & 7 & $5.9 \%$ \\
\hline Object vagueness & 6 & $5 \%$ \\
\hline Alterations in the application after the deadline & 2 & $1.7 \%$ \\
\hline Filing after the deadline & 1 & $0.8 \%$ \\
\hline Total & 119 & $100 \%$
\end{tabular}

According to the ANVISA study, concerning those 119 patent applications, the Brazilian Patent Office only denied patent for 6 cases and other 7 were archived. The other 106 applications were put on the backburner and did not go further whichever way within the framework of the Brazilian Patent Office. It is important to clarify that ANVISA cannot directly reject a patent application. After ANVISA's final prior consent decision, the patent application is sent back to the Brazilian Patent Office, which is in charge of publishing the final decision.

Thus, in the cases for which ANVISA has denied consent, the Brazilian Patent Office should publish their refusal - which has not been the case. Legally, from this refusal there are legal and administrative appeals available for the patent applicant. However, what has been taking place is a situation of uncertainty that brings consequences for the 
society as a whole, since the Brazilian Patent Office is keeping those applications open; in other words, it does not deny or grant the patent application.

\section{The Brazilian Patent Office inertia causes legal UNCERTAINTY AND CREATES DE FACTO MONOPOLY}

In practice, the inertia on the Brazilian Patent Office's part means that the object of patent application does not enter the public domain - which would happened when the refusal was published - affecting potential competition for the applicant intending to explore the technology, as there is legal uncertainty about the case in point. One may say that the patent applicant enjoys a de facto monopoly, given that legal uncertainty may drive away the competition from entering the market, which would not be the case if the patent had already been officially refused.

\section{BENEFITS OF ANVISA'S PRIOR CONSENT - INCLUDING ANALYSIS OF PATENTABILITY REQUIREMENTS}

In other cases, the participation of ANVISA in the process led the Brazilian Patent Office to change their view on the granting of a patent application that would have been issued if not for ANVISA. That happened in 90 cases. One of the emblematic cases that shows how the collaboration of ANVISA and the Brazilian Patent Office in the examination of applications of pharmaceutical patents can protect public health is the one concerning docetaxel, a medicine used mainly in cancer treatments.

The Brazilian Patent Office had issued their preliminary decision for the granting of the patent application filed by Aventis Pharma S/A ${ }^{378}$, but ANVISA denied it prior consent based on lack of inventive activity. the Brazilian Patent Office, after ANVISA's decision, altered their prior examination and denied the patent. The granting of this patent could have been of great detriment to public programs of distribution of medicines and for consumers at large, since the patent could be used to prevent competition in the supply of this product.

The participation of ANVISA in the analysis of pharmaceutical patent applications not only prevented the granting of several invalid patents, but also corrected dozens of imprecisions in applications that, in the Brazilian Patent Office's view, appeared ready to be granted, reducing or clarifying the reach of the object protected by patent and therefore, increasing the quality in the examination and granting of patents, affording more legitimacy to the patent system itself and yielding greater legal certainty. 
It is not for any other reason that the collaboration of health-related regulatory agencies and patent offices in the analyses of pharmaceutical patent applications was appointed as a measure to improve patent examinations under the perspective of public health, as highlighted by publication by expert Dr. Carlos Correa, with the seal of the World Health Organization (WHO) as well as the United Nations Conference on Trade and Development. $^{379}$

The WHO also highlighted the participation of the health sector in examination processes in the pharmaceutical area as beneficial to public health for their efforts to avoid the granting of inappropriate patents. ${ }^{380}$

\section{Recommendations}

\section{a) To Congress:}

Approve Bill H.R. 5402/2013 in order to promote legal certainty regarding the Sanitary Agency's attributions in giving prior consent, to eliminate the possibility of diverging interpretations regarding the Agency's attributions of examining the three patentability requirements, as well as the other two criteria established by the patent law - sufficiency of disclosure (enablement) and best mode (see Art. 3 of Bill 5402/2013, attached, that amends Art. 229-C of the Patent Act, and as well as Art. 7 of the 9782/99 Act on the National Sanitary System).

\section{b) To the Executive Branch:}

b.1) Immediately implement the Inter-ministerial Intellectual Property Group's (GIPI) resolution, and

b.2) To the Inter-ministerial Working Group (GTI) created by the Inter-ministerial Ordinance no. 1956/2011: expressly include the due observance of the three patentability requirements in the recommendations made by GTI, as well as the two other criteria established by the patent law - sufficiency of disclosure (enablement) and best mode.

\section{b.2) to the Brazilian Patent Office (INPI):}

b.2.1) follow the procedures recommended by the Inter-ministerial Working Group (GTI), in order to make the process clearer and afford it greater legal certainty, and

379 CORREA, Carlos (professor). Guidelines for the examination of pharmaceutical patents: Developing a public health perspective, WHO-ICTSD-UNCTAD. University of Buenos Aires: January 2007, p. 25. CIPIH/2006/1, p. 134. 


\section{b.2.2) publish the patent applications that are presently pending and that} have been examined by the Sanitary Agency for prior consent.

\section{b.3) to the Sanitary Agency - ANVISA:}

Keep duly observing, in the procedures of prior consent, the three patentability requirements, as well as the other two criteria established by the patent law sufficiency of disclosure (enablement) and best mode, as established by ANVISA's Resolution RDC 21/2013.

\section{Undisclosed test data protection}

World sanitary authorities, much like in Brazil, usually demand as condition for the authorization of commercialization registration of pharmaceutical products, the presentation of data regarding the quality, safety and efficacy (test data: pre-clinical and clinical studies phases I, II e III) of medicines, as well as information about the composition and characteristics of the product.

These data are fundamental for a precise examination with a view to approving the commercialization of any medicine, including generic medicine that also must prove the equivalence of active principles and medicine efficacy, to attest that the generic is actually equivalent to the reference product.

The reference pharmaceutical industry, however, has been making efforts to protect these test data with exclusivity, to avoid their use as comparative bases for the approval of third-party products - such as generics, for instance.

The WTO TRIPs Agreement demands only that those test data be protected against unfair commercial use (Article 39.3) - but there is no demand, however, for exclusivity rights. Nevertheless, some countries with high capacity for technological production, such as the United States, began granting exclusivity rights to test data and subsequent commercialization exclusivity during the same period, and they have been pressuring other countries to do the same.

\section{DATA EXCLUSIVITY HINDERS THE ENTRY OF GENERIC MEDICINES IN THE MARKET}

The exclusivity rights over test data prevent their use as a comparative basis for the equivalence factor in the registration of third-party products and pose an obstacle to the authorization for the commercialization of generic medicines for the duration of their term. Exclusivity of test data is, therefore, a measure that goes beyond international 
agreements (it is, therefore, TRIPs-plus) and hampers the entry of generic medicines in the market, besides discouraging national production, preventing the access by the Brazilian population to low-cost medicines, and should not be adopted by the Brazilian legislation as it is contrary to public interest and to the patent clause in the Constitution concerning the social, economic and technological development of the country.

The Patent Act, in its turn, sees the employment by third parties of non-disclosed test data presented to government bodies as condition for approval of the commercialization of products (Article 195, XIV) as a crime of unfair competition.

This Article of the Patent Act has recently come to be interpreted by some people and some instances of the Judicial Branch as a deterrent for the use of test data even by the Sanitary Agency itself for the authorization of commercialization of third-party products. In practice, this interpretation bestows exclusivity upon these data and, thus unduly amplifies what the Patent Act stipulates. This interpretation, which, in some cases, is adopted by the Judicial Branch, puts the policy of access to health and medicines in Brazil at risk and, for that, it should be reviewed.

Data exclusivity is a TRIPs-plus measure and, as such, should not be included in the Brazilian legislation, given the social interest in accessing protected technology as soon as possible, especially when it comes to technology that impact the realization of human rights, as is the case with medicines.

The United Nations Development Program (UNDP, 2010, p. 25) recommended that developing countries do not provide exclusivity in their national legislations.

\subsection{Registration of generic medicines in Brazil, and the impact of data exclusivity}

\section{Bioequivalence Test}

Companies interested in commercializing a generic medicine must present the competent authority with information demonstrating that their product is equivalent to the innovative product, without the need to prove that the product is safe and effective as required for the registration of the innovative product.

The reason is simple: it is a known and previously examined medicine, which indicates that it has been through all the mandatory steps towards registration - physical and chemical as well as non-clinical and clinical studies. This eliminates the need to conduct those studies all over again, as it is not reasonable to duplicate tests that will generate information already available. 


\section{The Repetition of Clinical Tests is Contrary to the Ethical Principles of the World Medical Association}

If the generic medicine underwent tests indicating that it is equivalent to the reference drug, then it makes no sense to demand that other animal and human tests be conducted, as the medicine being registered in actually the same.

In case the regulating agency is forbidden to base their examinations on those test results, the generic manufacturer will have to either a) conduct all tests demanded for the reference medicine all over again, in spite of the results being known, as the very same tests have already been conducted for the approval of the innovative product, or rather b) wait until the period for which data exclusivity was defined comes to term.

The unnecessary repetition of clinical tests is not only unreasonable but also absolutely contrary to the ethical principles of research on human beings adopted by the World Medical Association (Declaration of Helsinki).

\section{Only the Sanitary Agency uses test data - not the COMpetition}

To show that their product is equivalent to the reference medicine, the manufacturer of generic medicines needs not, at any given time, have access to or use test data for safety and efficacy presented by the manufacturer of the reference drug. Those data are used only as reference by the Sanitary Agency.

The use of those data, evidently, does not constitute an unfair competition offense such as typified in Article 195, XIV of the Patent Act. And the interpretation that aims at preventing ANVISA from granting market approval for generic medicines under that argument puts the access to medicines at risk, as well as public policies all over the country.

\subsection{Undisclosed test data vs data exclusivity}

\section{THE HISTORY OF NEGOTIATION OF THE TRIPs AGREEMENT SHOWS THAT TEST DATA EXCLUSIVITY WAS EXCLUDED FROM THE AgREEMENT}

During the negotiations of the TRIPs Agreement, the U.S. presented a proposal that would demand that all WTO member countries prohibit any use of test data without the consent of the data holder or without payment of a reasonable remuneration, if the referred use led to a commercial or competitive benefit by the government or any person involved. This proposal would oblige countries to bar any practice that generates such benefits. 
That proposal, however, has been rejected, and, therefore, was not included in the TRIPs Agreement. The final text only bears the expression "unfair commercial use". The main concern of Article 39.3 of the TRIPs Agreement is to prevent unfair competition in the use of data and not possible benefits to third parties.

The U.S. proposal also explicitly provided the prohibition of relying on test data presented by the manufacturer of the reference product. Nevertheless, this concept was not included in the final text of the TRIPs Agreement. In this context, the history of the negotiation of Article 39.3 of the TRIPs Agreement is clear and does not support the thesis that the Agreement would have the intention of granting exclusivity rights for test data, but, on the contrary, shows that such an idea has been rejected by the countries (Correa, 2002).

ANVISA, in its turn, does not publicize or make available any test data presented by the manufacturer of the reference product, but relies on them to infer that, once the safety and efficacy of a medicine are proven, all equivalents will also be safe and effective.

Data exclusivity, however, would keep the regulating agency from relying on the results of test data presented by the original manufacturer for the registration of equivalent medicines during the term of the exclusivity - and that would be an unreasonable measure, not to mention contrary to the national policy of extensive access to medicines, as well as contrary to social, technological and economic development in Brazil.

Article 194, XIV, of the Patent Act provides protection against the unfair use of undisclosed test data, as required by Article 39.3 of the TRIPs Agreement, but it does not confer exclusivity rights over data.

\section{UN BODIES STATE THAT USE OF TEST DATA BY REGULATING AGENCIES DOES NOT CHARACTERIZE UNFAIR COMMERCIAL USE}

Those litigations are based on the understanding that ANVISA, while relying on test data presented by the manufacturer of the reference medicine to infer the safety and efficacy of generic medicines, is committing an unfair competition offense.

The World Health Organization (OMS) (WHO, 2006) has already expressed their understanding that the use of test data by regulating agencies does not characterize unfair commercial use. ${ }^{381}$

Similarly, the United Nations Conference on Trade and Development (UNCTAD, 1996, p. 48), upon their analysis of Article 39.3 of the TRIPs Agreement, declared that "authorities are not prevented from using the knowledge of such data, for example, to 
analyze subsequent claims made by third parties to the registration of similar products". (translated from a Portuguese version)

Thus, the incorrect interpretation of Article 195, XIV, of the Patent Act, that it would grant data exclusivity and prevent ANVISA from registering generic medicines by relying on test data presented by the manufacturer of the reference medicine is contrary to the text of the Act, contrary to health public policies, contrary to what is determined by the WTO TRIPs Agreement, as well as its negotiation history, and contrary to the understanding of UN bodies.

\section{Recommendations}

\section{a) To Congress:}

Approve Bill H.R. 5402/2013 to promote legal certainty through an express guarantee that it is not illegal the use by government bodies, of undisclosed test data for marketing approval for equivalent products related to the products that have been previously presented (see Art. 3 of Bill 5402/2013, attached, that amends Art. 195 of the Patent Act).

\section{b) To the Executive Branch:}

\section{b.1) to the Sanitary Agency - ANVISA:}

Keep on using test data from the reference product for equivalence tests, without the fear that this practice may be argued as illicit.

\section{b.2) to the Competition Agency - CADE:}

Tackle anti-competitive and abusive practices caused by test data exclusivity that may block the entry of products in the market or harm market competition, and duly investigate and apply due sanctions.

\section{Sham litigation}

The biggest and most visible issue caused by the practice of abusive lawsuits, also known as sham litigation, is the barrier it established against the full access to medicines, to the production of generics and to free competition.

With the end of the monopoly of great pharmaceutical industries, which generated significant advances in competition in the pharmaceutical market, consequently, there was a noticeable increase in the number of unfair competition lawsuits in the sector. 
Abuse through lawsuits is not exclusive to the pharmaceutical-chemical field. The media has been reporting many disputes between Apple and Samsung regarding cellular telephone patents.

The patent system was created as a means to encourage innovation and economic, social and technological development. As such, it must not be unduly employed to inhibit competition through reckless suits and/or abuse of rights.

\section{Recommendations}

a) To the Executive Branch:

a.1) to the Competition Agency - CADE:

Tackle anti-competitive practices and act energetically towards curbing anticompetitive behavior and abuses in the field of patents and related rights.

\section{Compulsory license}

Compulsory license suspends the temporary legal monopoly created by the patent, allowing its object to be imported, produced or commercialized by any agents in the country without the authorization of the right holder, upon payment of royalties.

The Patent System instituted by the TRIPs Agreement allows WTO member countries to adopt the necessary measures to protect public health and promote public interest in sectors of vital importance for economic and technological development (Article 8). Compulsory license, usually known as the technically incorrect expression "patent infringement", is one of those measures. ${ }^{382}$ Besides public interest cases, the compulsory license can also be used as a market tool, to hinder anti-competition practices or in case of dependent patents, for instance - see chart in this chapter.

TRIPs deals with compulsory licenses in its Article 31, which deals with "other use without authorization of the right holder". This article lists conditions that must be present for the use of a compulsory license and that must be defined by each member country in their respective national legislations, in accordance with each country's national interests (WTO, 1994).

382 Compulsory license is the technical term as provided for in the Patent Act. The press in Brazil usually refers to compulsory licenses as "patent infringement" (quebra de patente), although it is not correct from a legal standpoint. Referring to compulsory licenses as "patent infringement" is not correct as the patent remains valid and held by its patent holder. Moreover, a mandatory payment of royalties for the use of the compulsorily licensed patent is due, as well as several legal requirements shall be observed. The difference regarding patents that were not compulsorily licensed is that their use can only occur after previous authorization by its holder. As for compulsorily licensed patents, there is no need for previous authorization, although royalties must be paid for its use, and the requirements established by the legislation must also be observed. 


\section{Cases liable of Compulsory license in the Brazilian Legislation}

1. exercising patent rights in an abusive form (art. 68);

2. exercising, by means of the patent, abuse of economic power (art. 68);

3. not manufacturing or incompletely manufacturing the object of patent in the Brazilian territory, or not wholly using the patented process - excepting economic unfeasibility cases (art. 68);

4. commercializing the patented product without meeting market needs (art. 68);

5. dependent patents (art. 70);

6. national emergency declared in public act of the Federal Executive Branch $(\text { art. } 71)^{383}$

7. public interest declared in act of the Federal Executive Branch (art. 71).

Two decrees have regulated the compulsory licensing provided by Article 71 of the Brazilian Patent Act. In 6 October 1999, then President Fernando Henrique Cardoso signed Decree 3.201, which allows the Ministries to issued compulsory licenses in cases of national emergency. Decree 4.830/2003 was signed by then President Luiz Inácio Lula da Silva, with the introduction of important changes in the previous decree, allowing the import of generic versions of compulsorily licensed products any time domestic production proves unviable and obligating the patent holder to reveal all necessary information for such production (Official Gazette, 2003). This Decree increased the Brazilian government's bargain power even more regarding pharmaceutical multinationals in the negotiation of the prices of patented antiretrovirals used in the treatment of AIDS.

As a result of the discounts granted by pharmaceutical multinational companies, the Ministry of Health’s expenses with antiretroviral therapies dropped from US\$336 million in 1999 to US\$ 167 million in 2002, in spite of the considerable increase in treated patients, from 79.245 to 119.500 . The increased competition between antiretrovirals suppliers generated by national production by Brazilian public laboratories gave way to considerable savings by the Government. ${ }^{384}$

383 Hypothetical situations in which compulsory licenses may be granted, stipulated in Article 71 of the Patent Act, are regulated by Decree 3.201/99.

384 The savings were not generated solely by the reduction on expenses with antiretroviral medicine but also by the significant drop on the number of hospital admittances related to AIDS. The ratio of hospitalizations and treated patients dropped from 1.65 in 1996 to 0.24 in 2001 (MELLO E SOUZA, 2007, p. 48). 


\section{The EfAVIREnZ CASE}

Due to some pharmaceutical multinationals' discontinuation of satisfactory discounts on prices of patented antiretrovirals, in 4 May 2007, Brazil issued their first compulsory license, for the antiretroviral efavirenz, commercialized by the multinational laboratory Merck. This license was initially valid for fiver years and has been recently renewed for five more. It was the first case of compulsory licensing of an antiretroviral in the Americas; Thailand, however, had already established the precedent by issuing compulsory licenses for the same antiretroviral, efavirenz, in November 2006, and for the combination lopinavir/ritonavir, by the Abbott laboratory, in January 2007.385

This Brazilian compulsory license established remuneration to Merck of $1.5 \%$ over the final product price by way of royalties. The generic version of the medicine was initially imported from India. In January 2009, however, the national production of efavirenz was announced by public laboratory Farmanguinhos. There was, however, an eightmonth delay in the domestic production of the medicine - as its active principle is produced by a Brazilian consortium that includes the laboratories Nortec, Cristália and Globe. The price of the national version, although less than half Merck's price, is higher than the same generic's in India, which evidences the scarcity of investments in technological training in the Brazilian pharmaceutical sector.

With the compulsory licensing of efavirenz, the Ministry of Health saved over R\$ 200 million between 2007 and 2011, an economy of 58,47\% in relation to what they would have spent on the purchase of Merck's patented product. ${ }^{386}$

The compulsory license mechanism has been used in several situations and in several countries, including technologically developed countries. ${ }^{387}$ Although they are publicly against the issuance of compulsory licenses for the treatment of diseases such as AIDS, developed countries like the United States of America, for instance, have made use or threatened to use the mechanism of compulsory license several times when they were intended as a guarantee for their interests. The Government of the U.S. announced that they would use the compulsory license mechanism in the widely known case with the drug Cipro, by Bayer, in the occasion of the biological attacks with anthrax in that country.

385 For a discussion about compulsory licenses granted in Thailand, Brazil, Canada and Rwanda, see Laurence Helfer and Graeme Austin, "Human Rights and Intellectual Property: Mapping the Global Interface", Cambridge, 2011, pp. 127-138.

386 Francisco Viegas Neves da Silva; Ronaldo Hallal and André Guimarães. Compulsory License and Access to Medicines: Economics Savings of Efavirenz in Brazil. Presented during the XIX International AIDS Conference, 2012. Available at http://pag.aids2012.org/PAGMaterial/aids2012/PPT/940_3379/cl\%20 efv\%20final.pptx

387 See study by the Knowledge Ecology International - KEI, Recent examples of the use of compulsory licenses on patents available at http://www.keionline.org/misc-docs/recent_cls.pdf. Access: 22 January 2009. 


\section{LOCAL PRODUCTION REQUIREMENT}

In response to the actions of the Brazilian government regarding the production of highly profitable antiretroviral patented by or licensed exclusively to companies from the United States, the government of the U.S. initiated an inquiry at the WTO against Brazil in 1 February 2001. The stated reason was Article 68, § 1, item I, of the Brazilian Patent Act.

The Article in question determines that "the non-exploitation of the subject matter of the patent in the territory of Brazil, by lack of manufacture or incomplete manufacture of the product or, furthermore, by lack of complete use of a patented process, except in the case of non-exploitation due to economic unviability, when importation will be admitted" (Patent Act, 1996). In other words, if the object of patent is not locally produced or if it is produced only partially in Brazil, the patent can be compulsorily licensed. Which means, in practice, an incentive to technological training in Brazil in order to meet the demand of the patent clause of the Brazilian Constitution (Art. $5^{\circ}$, XXIX), that the patent system promotes the country's technological, economic and social development.

Brazil does not want to be a mere buyer of finished (and patented) products. It wants there to be technology transfer and technology training in the country. Otherwise, we will eternally be buyers of finished products without ever developing technology in our country. That is why the clause about local production is so important.

Representatives of the United States have argued, however, that this article violated Article 27.1 of TRIPs, according to which "patent rights [are] enjoyable without discrimination as to the place of invention, the field of technology and whether products are imported or locally produced."

The United States Trade Representative argued that "Article 68 is not related to health and access to medicines, but everyone discriminates against imported products and favors Brazilian products. In summary, Article 68 represents a protectionist measure that aims to create jobs for Brazilian” (USTR, 2001, at 10). (translated from a Portuguese version)

Brazil expressed the counter-argument that our Patent Act follows the rulings of the Paris Convention, pointing to Article 2.1 of the TRIPs Agreement, which explains: "in respect of Parts II, III and IV of this Agreement, Members shall comply with Articles 1 through 12, and Article 19, of the Paris Convention (1967)" (WTO, 1994).

Without local manufacturing of the patent object, Brazil becomes a mere consumer and packer of others' technology. Using the patent as a tool for retaining exclusivity of rights, preventing the use, production and commercialization by third parties, without, however, the patent holder actually exploring the object in national territory, is clearly 
contrary to the Constitutional patent clause, as well as to the TRIPs Agreement (Articles 7 and 8), and to the goals of the Patent Act (Art. 2) and the patent system itself.

This practice (using the patent as a way of obtaining exclusivity of rights, barring the use, production and commercialization by third parties, without, however, the exploration of its object in national territory by the patent holder) is a clear form of abuse of rights which, in fact, is restrained by the national judicial order, besides being expressly dealt with both in the Patent Act (Art. 68) and the founding act of the Brazilian System of Competition Defense (Act 12.529/2011).

One way or another (whether through the absence or insufficiency of local production; whether by means of abuse of rights), the patent object that is not locally manufactured can and should, if necessary to rebalance public and private interests, be compulsorily licensed. In that regard, China, in 2008, reviewed their patent act exactly to accommodate a similar measure to Brazil. If the patent holder, in that country, after three years from the granting date and four years after the filing date, still has not explored or sufficiently explores the patent object without justified reason, a compulsory license can be issued.

\section{ANTI-COMPETITION PRACTICES}

Another independent option that is not directly related to the discussion above is the issuance of compulsory licenses based in anti-competition practices, which are exempt from the demands of Article 31(f) of the TRIPs Agreement. Article 31(k) of the TRIPs Agreement states that " $[\mathrm{m}]$ embers are not obliged to apply the conditions set forth in subparagraphs (b) and (f) where such use is permitted to remedy a practice determined after judicial or administrative process to be anti-competitive." (WTO, 1994).

Concerning the anti-competition aspects regarding technology and patents, Act 12.529/2011, establishing the Brazilian System for the Defense of Competition, lists several conducts that are characterized as infringements of the economic order (Art. 36. and items V, VIII, XI, XIV, XVIII, XIX).

The Administrative Council for Economic Defense (CADE), as well as the Judicial Branch, have legal grounds to prevent and punish anti-competition acts in the scope of patents and general technologies. In that regard, in fact, the U.S. has issued compulsory licenses in more than 100 anti-trust cases in that country. ${ }^{388}$

In spite of the benefits brought by the compulsory licensing of efavirenz, which resulted in economy of public resources from the purchase of generic medicines, this has been the only compulsory license granted in the country.

388 See Commission on Intellectual Property Rights. Integrating intellectual property rights and developing policy, Report of the Commission on intellectual property rights, London, UK 2002. 
President Dilma Rousseff ${ }^{389}$, during a speech delivered at the High-Level Meeting about Non-Transmissible Chronic Diseases hosted in September 2011 by the United Nations and by the World Health Organization, defended the use of the TRIPs flexibilities also in the context of those diseases, going further than the case for HIV/AIDS. The compulsory license is a measure that can lessen the negative impacts made by the temporary legal monopoly on the access to essential medicines and should be used whenever necessary for the promotion of public interests. We suggest, however, that Brazil not only uses compulsory licenses, but also produces locally the medicines that are essential to the population.

\section{Recommendations}

a) To the Executive Branch:

\section{a.1) to the Competition Agency - CADE:}

Tackle anti-competitive practices and act energetically towards curbing anticompetitive behavior and abuses in the field of patents and related rights, and recommend the issuance of compulsory licenses if necessary for the correction, in a case by case basis, of abusive or anti-competitive behavior.

\section{a.2) to the Inter-ministerial Group on Intellectual Property - GIPI:}

Create a workgroup to discuss all the possibilities of compulsory licensing in Brazil, as provided for in the Patent Act, in the Brazilian System of Competition Defense, as well as in the TRIPs Agreement, in order to lead a comparative study on how other countries, such as Thailand, India, Canada, United States and Argentina, for instance, have been applying in practice the compulsory license mechanism, in order for the GIPI to create guidelines, to support the Federal Executive Branch in taking measures related to compulsory licenses in the country.

\section{a.3) to the President's Office:}

In case there is no local production or insufficient local production of the patent, apply the provision as set forth in Art. 68 of the Patent Act and issue a compulsory license due to lack of local production - with the aim of promoting capacitybuilding and technology transfer. 


\section{Genetic resources, traditional knowledge, and benefit sharing}

While countries that are presently technologically developed seek to expand (increasingly so) patent rights and related rights, not just within their own countries, but also in the international sphere, those very technologically developed countries practice bio piracy in large scale. In other words, they appropriate genetic resources and/or traditional knowledge from countries with rich fauna, flora and natural resources and populations in possession of information about the use of the traditional knowledge, without, however, asking for previous authorization to use the genetic resources or traditional knowledge, and without equitable sharing of the accrued benefits.

We do not advocate for the prohibition of use of genetic resources and traditional knowledge, but for a balanced use, not only in respect to the environment but also to local populations. To that end, an independent empirical study must be undertaken to map the situation and so that regulations in this field fulfill all interests involved in a balance and just manner.

The TRIPs Agreement does not include demands of prior consent from the provider of genetic material and associated knowledge and of the just and equitable distribution of benefits accrued from their use. With the goal of conciliating the TRIPs Agreement and the Convention on Biological Diversity (CBD), developing countries have been proposing an amendment to the TRIPs Council, but this proposal is being rejected by several developed countries, in a situation of "two weights, two measuring units", as the developed countries demand the protection of advanced technologies that they are capable of developing, but not for genetic resources and traditional knowledge largely from developing countries, denying them prior consent as well as just and equitable sharing.

In 1995, through the Bill 306, the first discussion in the country on access to genetic resources and benefit sharing (ABS) was launched. However, it was not until 2001, by means of the Provisional Act (Medida Provisória - MP) 2.186-16 that the discussion actually gained a statutory body. The MP defined genetic heritage and demarcated its access in Brazil.

MP 2.186-16 was also responsible for the creation of the Brazilian Council for Genetic Heritage Management (CGEN). Attached to the Ministry of environment the CGEN is responsible for the evaluation of research projects involving access to genetic heritage and its associated traditional for scientific research, bio prospection and technological development. 


\section{ACHEFLAN CASE - BALEEIRA HERB}

A well-known case involved the Ache laboratory, regarding the production of antiinflammatory medication "Acheflan", using the extract of the erva-baleeira (baleeira herb), a plant traditionally used by natives in the coast of the State of São Paulo to treat contusions and inflammatory processes. One of the laboratory directors, residing in the coast of São Paulo, had the habit of playing soccer with members of the native caiçara community in the region and used the "garrafadas" (bottled ointments) to heal sports lesions. As reported, this director had the idea of transforming the caiçara knowledge in phytomedication. Researches were conducted from 1998 to 2004 to isolate the active principles of erva baleeira and, with the approval of ANVISA, the patent application was filed with the Brazilian Patent Office in 2002. CGEN saw fit to examine the case because of the access to traditional knowledge involved. The Ache laboratory proceeded to file a court injunction to guarantee that the product would be launched without CGEN interference and succeeded. The product was launched and became a market leader (Mariot, 2010).

It is imperative to regulate the use of genetic resources and traditional knowledge, including prior consent and the just and equitable sharing of benefits in order to, on one hand, facilitate the access of national companies that wish to develop products based on national biodiversity and/or traditional knowledge and, on the other had, establish a manner of just and equitable distribution of the economic result accrued from the use of those resources and knowledge. Simplifying the treatment of the subject is essential for its success as public policy and as regulation, both nationally and internationally, as well as for the sustainability of national biodiversity and autochthonous communities.

\section{Recommendations}

a) To Congress: undertake an independent study in order to map out the Brazilian scenario concerning the use of genetic resources and traditional knowledge and its economic, social and legal implications for Brazil, to propose, with an empirical basis, recommendations and possible legislative proposals for a more balanced treatment of the issue in Brazil. 


\section{Prize system as an alternative to promote innovation}

In addition to the traditional system of patent and related rights, there are recent proposals for the creation of a prize system, as well as an open model for research, development and innovation. Those proposals are briefly discussed as follows.

\section{INNOVATION CRISIS IN THE WORLD PHARMACEUTICAL INDUSTRY}

The innovation crisis in the world pharmaceutical industry is a highly impacting element of discussions. According to experts Light and Lexchin (2012), many of the new medicines launched over the last few years consist of slight alterations of existing products. According to the authors: "Out of 218 drugs approved by the FDA from 1978 to 1989, only 34 (15.6\%) were judged as important therapeutic gains. Covering a roughly similar time period (1974-94), the industry's Barral report on all internationally marketed new drugs concluded that only $11 \%$ were therapeutically and pharmacologically innovative. Since the mid-1990s, independent reviews have also concluded that about $85-90 \%$ of all new drugs provide few or no clinical advantages for patients."

\section{MARKet LOGIC AND NEGLECTED DISEASES}

Research and production in the pharmaceutical industry do not prove satisfactory regarding the development of technologies and health solutions of interest to neglected populations. As explained by Gadelha (2009), "in the articulation of the innovation dynamics with society, it can be said that the virtuous circle of investment in R\&D and marketing, innovation, profitability and growth has a perverse dimension in which the market logic detaches itself from health needs, especially in those countries and populations with less buying power and high incidence of neglected diseases."

The present system of promoting innovation based on patents has been proven inefficient for several countries, in two dimensions: innovation and access. As the present system is based on the sale of products at elevated prices with a view to the right to exclusivity, that hampers competition, guaranteed by patents or related rights, this system has allocated resources guided by market interests and not necessarily health needs.

That is why, among other motives, the present patent system has been inefficient in tackling several health issues in countries with populations with less purchasing power. On the other hand, when there are existing patents for medical products, the elevated prices have been working as a substantial barrier to access to medicines, which, in 
many cases, ends up excluding millions of people, in several countries, from the access to those medicines that are essential to health. Starting with this diagnosis, there has been a growing effort, presently led by the WHO, to identify alternatives that may be employed in directing research, development and innovation investments towards the real health needs, especially in less technologically advanced countries, and making the final medicines available at affordable prices.

Regarding research costs, in spite of the elevated figures publicized by the pharmaceutical industry and by some academics (Dimasi et al, 2003; Dimasi et al; 2007), data from the United States indicate that basic research, which yields results that are used by pharmaceutical companies for highly profitable commercial activities, is strongly subsidized by public coffers. According to Light and Lexchin (2012), over 80\% of all basic research investment towards the development of new medicines and new vaccines comes from public sources.

\section{MARKETING EXPENSES ARE GREATER THAN R\&D}

A considerable part of the final price of medicines corresponds to marketing expenses, which are in fact greater than expenses with research and development (R\&D). Dr. Marcia Angell (2008), from Harvard University, calculates that marketing expenses increase pharmaceutical products' prices by about $30 \%$.

\section{PRIZE SYSTEM}

In addition to the proposal of public financing from a GDP percentage, a relevant path to incentives in health innovation is the creation of prizes.

Besides, market exclusivity leads to the application of huge sums in product marketing, which elevates its final price even further. Faced with the scarcity of researches for tropical diseases and other neglected diseases that yield low or uncertain financial return in comparison to top-selling medicines, it is necessary to think of alternative incentives (not via patents and related rights) to stimulate innovation and avoid exclusivity conditions that harm public health.

Prizes have been proving another alternative to reward research and innovation and to keep the final price within a balanced range. Prizes can be used to stimulate research with a previously defined priority (by the Ministry of Health, for instance) and encouraging work in truly needy areas. The implementation of funds can allow the government to have more control over what to develop, how much to spend in each research phase, how to use research results and how to distribute the products (medicines, vaccines, diagnosis kits, among others). 
In the prize system, research data can be freely used in other researches without the risk of disobeying clauses in technology contracts based in an exclusivity regime. In that sense, Stiglitz (2006) emphasizes that "the medical prize fund would ensure that we make the best possible use of whatever knowledge we acquire".

In short, the implementation of stable public resources committed to a research and production model focused on free knowledge sharing, as well as a prize system, can help take less favored countries to another development level. The benefits can be many: scientific and technological training, local production, employment and income, formulation of own priorities, access to essential products and social justice.

\section{Recommendations}

a) To the Executive Branch:

a.1) to the Executive Branch:

a.1.1) elaborate a draft bill creating a minimum contribution of $0.01 \%$ of the Gross Domestic Product for the creation of a research and development fund for the area of neglected diseases and other national interest public health matters. Evaluate the convenience of using as a source of revenue, besides the GDP, part of the taxes from tobacco and alcoholic beverages. The research results stemming from this financial contribution would be placed under public domain or a mandatory open access scheme. Research must be conducted by Brazilian institutions or companies based on a definition of priorities coordinated by the Ministries of Health, and Science, Technology and Innovation; and

a.1.2) elaborate a draft bill for the creation of the Brazilian Health Innovation Prize, with the goal of encouraging health research under a non-exclusivity regime (open access scheme) based on the definition of priorities coordinated by the Ministries of Health, and of Science, Technology and Innovation.

\section{a.2) to the Ministry of Foreign Affairs:}

Negotiate along with the World Health Organization and/or the World Trade Organization and/or the World Intellectual Property Organization the possibility of creating an international instrument for the creation and implementation of a global fund for the financing and incentive of health research under an open access regime. 


\section{Software patents}

In the beginning of 2012, IPNPI conducted a public consultation, for 60 days, about a proposal of a guideline about "procedures for the examinations of patent applications involving inventions implemented by computer software". 390

According to a study by jurists and computer experts from the University of São Paulo and the Getúlio Vargas Foundation, the European Commission

published a directive proposal for 2002 according to which a computer software would be patentable [...]. After five years of a an extensive indepth public debate, the proposal was voted and rejected by the European Parliament, the highest legislative sphere in the community scope. One of the chief bases for rejection was the risk of hindering software development in Europe [...]..$^{391}$ (translated from the original)

Ten years after Europe extensively discussed the subject, in a public and inclusive manner, and for 5 years, the Brazilian Patent Office conducts a public consultation for 60 days to discuss the same subject - which was massively rejected by the European Parliament due to the risks that such patents could offer to the European technology market.

There is no discussion about guidelines for examination of software patents without an extensive and inclusive debate about the risks and opportunities of such patenting, as well as independent studies about the eventual positive and negative impacts that the patents of inventions implemented through computer software can make in Brazil.

According to the World Trade Organization, the regime of intellectual protection of computer software's is the same conferred to literary works by the copyright law in force, according to Article 10.1 of the TRIPs Agreement. Software, therefore, is already protected by the Copyright Act (Act no. 9.610/98) and by specific legislation in Brazil (Act no. 9.609/98).

Software is a purely abstract conception, a mathematical method, and is not subject to industrial application. In other words, software is an idea, a mathematical formula. And ideas or purely abstract conceptions may not and cannot be patented, according to Article 10 of the Patent Act (Act no. 9.279/96).

Whether we consider software in itself or an invention implemented by software, which changes nothing about the public technology policy in practice. If one admits that a (supposed) invention may be implemented by computer software, the patent would

390 Public Consultation no. 1, published in the Official Gazette in 16 March 2012.

391 See Eros Roberto Grau, et. al., "Por um Brasil Inovador: Estudo da FGV e USP contra a Concessão de Patentes para Programas de Computador no Brasil", p. 6. 
be granted for the ensemble, including the computer software. In practice, the patent would be granted to the software.

So much so that many patent grants by the Brazilian Patent Office were based on applications that, in order to avoid the legal impediment regarding computer software in itself, characterized computer software as industrial processes or methods.

In practice, software patents are being granted, in clear confrontation of legislation and national interest - and, more than that, without any type of debate on the subject, whether with society, with the business sector, or with academic field experts, not even with the Ministries that are members of the Inter-ministerial Group on Intellectual Property (GIPI).

The above-mentioned technical study by USP and FGV is categorical in explaining that [the] Brazilian Patent Office's proposal would have the mere goal of "helping with the technical examination of patent applications involving inventions implemented by computer programs"; however, in doing so, they admit, through a non-statutory diploma (resolution of the ministerial body), that the software is subject to the patent regime, which is the opposite of the regime adopted by the country's legislation. The contents of the "Guidelines" are made even more surprising by conferring extensive patentability to computer software encompassing technical effects both in the physical and virtual worlds, whether the software is embodied in a machine or not, and including computing processes such as optimization of text processors or benefits in the user interface. All that sits on the interpretation that the "software in itself" (which cannot be an invention by force of Art. 10, item V of the Industrial Property Act no. 9.279/96) would consist of just the software without a technical effect; all the others with technical application or utility being patentable. But practical usefulness is one of the dimensions of any software, which gives the the Brazilian Patent Office Guidelines a potential impact in terms of software patentability even bigger than the U.S.'s, making space for any software description to have invention status and be eligible for patenting. ${ }^{392}$

The permission of software patenting in Brazil casts national software developing businesses into legal uncertainty, as each line of code developed in Brazil becomes subject to questioning over its origin and ownership.

The most grievous issue is that software patents block competition and innovation in the information technology sector, since, in order to make competing software's, 
different businesses work towards tackling the same issues and, frequently, come up with similar or equal solutions. And, as the patent bestows rights of functionality, it does not matter whether a software developed by a competing business has been done entirely independently: infringement happens anyhow, if the functionalities are identical or very similar - even if the software programs were developed independently.

Innovation in the software industry, for its specific features, works in a sequential and cumulative manner. Computer software programs are not static reactions: they suffer constant adaptations and improvements. ${ }^{393}$ This sequential innovation "builds up cumulatively over other inventions, unlike the airtight innovation limited to other products in many other areas". ${ }^{394}$ At the same time, and for the same reason, computer software programs are frequently written based on concepts and subroutines of other pre-existing software, including usability and accessibility for persons with disabilities. ${ }^{395}$ That is the nature of the construction of computer program algorithms. However, the institute of patents is not appropriate for the software sector, at the risk of stifling innovation in the information technology field.

In the words of the respected Commission for Intellectual Property Rights of the Government of the United States, "the process of innovation may be cumulative, and iterative, drawing on a range of prior inventions invented independently, and feeding into further independent research processes by others. [...]The development of software is very much a case of building incrementally on what exists already." And the abovementioned Commission closes with the following recommendation: "[e]xclude from patentability computer programs and business methods". ${ }^{396}$

Professors at Harvard and Brandeis Josh Lerner and Adam Jaffe show that "the cumulative nature of innovation in several important industries puts multiple innovative firms in constant conflict with each other. The patent system seems increasingly to be a source of uncertainty and costs (...)." 397

393 See testimony by the deputy chief attorney of Microsof before the Federal Trade Commission of the United States, The Evolving IP Market Place - Aligning Patent Notice and Remedies with Competition, 2011, pp. 44-45.

394 See Eros Roberto Grau, et. al., op. cit., p. 19.

395 See Julie Cohen e Mark Lemley, Patent scope and innovation in the software industry, California Law Review, Vol. 89, n. 1, Jan., 2001, p. 41.

396 See Reino Unido, Comissão para Direitos de Propriedade Intelectual (CIPR), "Relatório da Comissão para Direitos de Propriedade Intelectual - Integrando Direitos de Propriedade Intelectual e Política de Desenvolvimento", Londres, 2002, p. 112.

397 See Adam B. JAFFE e Josh LERNER, Innovation and Its Discontents - How our Broken Patent System is Endangering Innovation and Progress, and What to Do About it, Princeton, 2004, p. 76. 


\section{SMARTPHONE INDUSTRY SPENDS OVER US\$ 20 BILLION WITH LAWSUITS ON SOFTWARE PATENTS}

A Stanford University study showed that the smartphone sector spent, over the last two years, US\$ 20 billion in patent litigations and patent purchases; a sum equivalent to eight NASA Curiosity missions to Mars. ${ }^{398}$

\section{ApPle AND GOOgle SPEND MORE WITH SOFTWARE PATENT LAWSUITS THAT WITH R\&D}

In 2011, lawsuit expenses at Apple and Google, as well as patent purchase expenses, exceeded the companies' investments in research and development of new products. ${ }^{399}$ In the U.S., from 1995 to 2011, software patent holders won less than $25 \%$ of court cases. And the more aggressive patent holders do even worse: among the most litigated patents - those in eight or more court cases -, holders have won less than $10 \%$ of the cases ${ }^{400}$ which clearly shows that those patents are extremely weak and, in the majority, invalid, as they were granted in non-compliance with patentability requirements - which results in strong legal uncertainty for society, and ends up stifling innovation, going against the goals of the patent system.

\section{European Parlament Rejects Software Patents}

The impact of software patents in Brazil tends to be extremely detrimental for the still incipient national industry. Even in more developed markets such as the European Union, concerns with stifling innovation in the information technology field were the theme of an extensive public debate. In 2005, the European Parliament ${ }^{401}$ rejected software patents by 648 votes, with only 14 favorable votes, in an evident demonstration of the losses that such patents could bring to the European market.

398 See DUHIGG, Charles e LOHR, Steve. The Patent, Used as a Sword in New York Times. 7 de outubro de 2012.

399 See Charles Duhigg e Steve Lohr. Op. cit.

400 See Adi KAMDAR e Daniel NAZER, Deep Dive: Software Patents and the Rise of Patent Trolls, 28.02.2013, available at https://www.eff.org/deeplinks/2013/02/deep-dive-software-patents-and-rise-patent-trolls.

401 Common Position (EC) n. 20/2005. 


\section{Recommendations}

a) To the Executive Branch:

a.1) to the Inter-ministerial Group on Intellectual Property - GIPI:

a.1.1) commission independent technical studies on the potential risks and benefits arising from granting computer-implemented patents for the economy and the technological and social development of Brazil; and

a.1.2) after the consultation mentioned in the item above, debate and approve the Patent Office examination guideline for computerimplemented inventions.

a.2) to the Brazilian Patent Office (INPI):

a.2.1) propose new examination guidelines for computer-implemented inventions, observing, inclusively and necessarily, the patentability requirements standards recommended in this Report, as well as the result of the studies mentioned above, and the abundant national and international literature, and the contributions given by the public consultation of 2012. Launch a new public consultation on the new proposal for the examination guidelines; and

a.2.2) while the studies and the proposal for new guidelines are elaborated and discussed, suspend the examination of patent applications on computer-implemented inventions.

\section{Patent Prosecution Highway (PPH)}

Bilateral agreements known as Patent Prosecution Highways (PPHs) were created with the goal of accelerating the process of patent examination by means of collaboration between patent offices in signatory countries. A PPH consists of a fast-track list among patent applications involving applicants from the signatory countries of a bilateral agreement.

During President Barack Obama's visit to Brazil in March 2011, the signature of a PPH Agreement between the USPTO and the Brazilian Patent Office was announced. Its goal was to reduce the examination time for patents from the U.S. in Brazil and vice-versa, allowing the offices to rely on the work done by the office that received the first application. From the 13 agreements that were to be signed between the two countries during Obama's visit, the PPH was the only one that was not signed, given the controversy over a lack of debate about the subject in Brazil. 
Adhesion to the PPH system is one of the the Brazilian Patent Office proposals to reduce their backlog, or delay in the examination of patent applications reaching for a four-year period of analysis for each patent goal until 2014 against the present eight to ten years for some technological fields such as pharmaceutical. This is a subject of extreme interest for the Brazil-U.S. Business Council, a private sector organization, which announced they are making efforts towards the signature of the $\mathrm{PPH}^{402}$

In case a company based in the United States ${ }^{403}$ wants to require a patent for its technology also at the Brazilian Patent Office, it would file the application at the Brazilian office, indicating the preference for the PPH route. It would then provide the entire documentation originally presented to the USPTO. The Brazilian examiner would analyze the U.S. application documents and would then be able to accept the work of the USPTO examiner based on the legislation and public policies of the original patent country.

With the PPH, the patent claim that arrives from the USPTO at the Brazilian Patent Office would already have claims previously analyzed by examiners from the U.S.

According to the position of the GTPI (2011), the adoption of this system would feed the the Brazilian Patent Office hopes of artificially decreasing Brazilian backlog. However, the increase in the number of qualified examiners would be the only way to actually reduce delays in the Brazilian examinations and prevent a quality drop, a fundamental item for the granting of patents to respect the Constitutional patent clause of promoting economic, social and technological development in Brazil. In the U.S., there are over 6,000 examiners, while in Brazil there are 273. The report reinforced fears regarding a quality downfall in the examinations, given that the patentability criteria adopted by the USPTO are more wide-ranging. There is an evident disparity in public policies between Brazil and the U.S., bearing in mind, among other factors, the different technological development of both countries.

402 More information at http://www.brazilcouncil.org/task-forces/innovation.

403 Not necessarily North American capital but they must be a legal entity from the United States and the first patent application must have been filed at the USPTO (InovaçãoUnicamp, 2011). 


\section{Recommendations}

a) To the Executive Branch:

a.1) to the President's Office:

a.1.1) undertake independent studies prior to the signature of any agreement or partnership between countries or with public bodies of other countries, in order to identify possible positive and/or negative impacts that such agreements or partnerships may have in the economy and to the development of the Brazilian society;

a.1.2) submit patent and related rights issues for prior analysis by the Inter-ministerial Group on Intellectual Property (GIPI) before taking any decision on those matters; and

a.1.3) refrain from signing the PPH agreement as proposed, bearing in mind the previous evidence put forth by this Report.

\section{a.2) to the Patent Office - INPI:}

Submit to prior review and approval by the Inter-ministerial Group on Intellectual Property (GIPI) any proposal to implement collaboration schemes on the examination of patents or trademarks, including but not limited to possible "harmonization" with other Intellectual Property Offices from other countries, such as, but not limited to the e-PEC system.

\section{Patent backlog and patent quality}

The contingent of patent examiners in the Institute has not been, increasing with the patent applications, which has been causing, among other reasons, a considerable delay on patent examinations - known as backlog. In other words, the average delays in the analysis (whether to grant it or deny it) of a patent.

The number of patents with pending examinations from 2005 to 2011 has grown 56\%, going from 110,854 applications pending analysis to 173,000.

From 2005 on, the number of the Brazilian Patent Office patent examiners doubled, which constitutes a laudable improvement. Data from 2008 indicates that the Brazilian Patent Office had 275 examiners that year. By the end of 2011, according to management report from the Patent Board (DIRPA) at the Brazilian Patent Office, the number of patent examiners had dropped to 229. In 2012, through public statements from the Institute, as well as by a sample from the internal system, it is estimated that the Brazilian Patent Office has around 230 patent examiners - fewer in comparison to 2008 due to transfers to other boards, resignations, retirements, among other factors. 
Everything points out to the insufficiency of this number of examiners to tackle, without detriment to quality, the growing patent applications filed at the autarchy.

In 2012, the Brazilian Patent Office published data about a supposed reduction of backlog in patent examinations. According to the Brazilian Patent Office, in 2006, the patent application examination backlog was of 11.6 years. In 2011, still according to the Institute, the backlog supposedly dropped to 5.4 years against 8.3 from the previous year, 2010 .

A simple comparison between the two graphs above shows clearly that at least part of the presented data is not in accord with reality. The number of patents pending examination has been growing year after year, having reached 173,000 in 2011. Paradoxically, the average time span of applications (without increase in the number of examiners) had supposedly gone down by 8.3 years, in 2010, to 5.4 years, in 2011, according to data publicized by the Brazilian Patent Office.

The British magazine The Economist published a piece in November 2012 about the reduction of patent backlog at the Brazilian Patent Office, relying on data sent by the Brazilian Patent Office itself.404 The piece found repercussion among field specialists, including patent attorneys, who suspected the data, since they know that the reality they are faced with everyday does not match the data presented by the Institute.

Even before that information had been widely publicized by The Economist, the Comptroller-General (CGU), linked to the Presidency of the Republic, conducted an auditing of the Brazilian Patent Office and found that the methodology, the nomenclature and the data used and presented by the Brazilian Patent Office has flaws that needed correction. According to the CGU, the Brazilian Patent Office started including decisions for patent archiving along with the data. In the words of CGU, "it is worth highlighting that the inclusion of archiving decisions in the denominator made the indicator lose the comparability feature throughout the years."

As a result from the auditing, the Brazilian Patent Office was forced to recalculate and correct data.

There is evidence, then, indicating that patent backlog, contrary to what the Brazilian Patent Office publicized, has only been increasing instead of decreasing. Some patent attorneys suggest that the present backlog is 10 years.

In any case, a very long delay in patent examination ends up causing legal uncertainty. Uncertainty not only for patent applicants but also for their potential competition, as well as to society as a whole. Applicants do not know if their patents will be granted and, on the meantime (which, nowadays, may last 10 years), they do not know whether they have or do not have exclusive rights to use the claims stated in the patent application. 
The competition does not know if they can explore the object of patent application without being at risk of prosecution and fining. And society loses. It loses because it does not know if the one exploring the patent has or will have any rights over it, or if the competition may explore the same object. If there is exploration done by the competition, it may well be that on the next day a court order demands the withdrawal of all products from the market. The population loses. Everyone involved loses. Uncertainty is considerable.

\section{QuALITY OF PATENT EXAMINATIONS}

Quantity does not necessarily mean quality. One of the essential requirements for the patent system not to lose its legitimacy before society is that it be a balanced system. Frivolous or even invalid patents are not suitable to support the legitimacy of the patent system. In that regard, the Federal Trade Commission warns:, "[...] poor quality patents can discourage innovation by creating uncertainty and raising costs." 405

However, the quantity of examiners is not the only thing that must increase, but the quality of examinations must be rigorously observed. It is not enough to reduce backlog in patent examinations and, in fact, under that pretext, diminish the quality of examinations. If the quality of examinations is negatively affected, possibly caused by hurrying the examinations to reduce backlog, the patent system as a whole will be harmed and its legitimacy will be shaken.

About that, the Hargreaves Report, from the Government of the United States, is emphatic: "Increased pressure on patent offices to examine the large numbers of applications and reduce these backlogs may lead to the grant of even more low quality patents, worsening the costs of uncertainty."

Regarding the patentability requirements as well as the other criteria established by the Patent Act, those also can and should apply, in order to improve the quality of patents in Brazil and, additionally, promote the Constitutional of the patent system. ${ }^{407}$

405 See Federal Trade Commission, "The Evolving IP Market Place - Aligning Patent Notice and Remedies with Competition", 2011, p. 7.

406 See lan Hargreaves, "Digital Opportunity. A Review of Intellectual Property and Growth. An Independent Report by Professor lan Hargreaves", 2011, p. 55.

407 The patentability requirements are discussed in the next chapter. 


\section{Recommendations}

a) To the Executive Branch:

\section{a.1) to the Brazilian Patent Office (INPI):}

a.1.1) hire ad hoc patent examiners in order to reduce the patent backlog to a number of years considered ideal, within reason, and without detriment to the quality of examination; ${ }^{408}$

a.1.2) hire trained, and to be trained, new patent examiners to compose the permanent staff, with remuneration that complies with the strategic function that they will tackle for the country, so that the total number of examiners will suffice to properly address the large amount of patent applications;

a.1.3) invest in resources so that examiners have access to other patent databases, that will prove helpful in the analysis of the patentability requirements; and

a.1.4) apply high standards to the requirements of novelty, nonobviousness, industrial application, sufficiency of disclosure (enablement) and best mode, at the risk of granting frivolous or invalid patents. ${ }^{409}$

\section{Creation of the Council of Intellectual Property Rights (CoDiPI), and the role of the Inter-ministerial Group on IP (GIPI)}

Some of those controversies have been exemplified in the present Report, such as the case of prior consent (Brazilian Patent Office - ANVISA), the case of new forms of known substances and new uses (Brazilian Patent Office - GIPI), and the PPH case (Brazilian Patent Office - MRE/Presidency of the Republic), among others.

The solution to those controversies is connected to the need for more clarity regarding what kind of policy of patent and related rights the Brazilian State wants and should follow:

408 See proposal by Ronaldo Mota, Secretary of Technological Development and Innovation, for the Ministry of Science, Technology and Innovation (MCTI), in a lecture given in August 17, 2011, at the Chamber of Deputies, contained in annex $\mathrm{V}$ of the Portuguese version of this Report.

409 This is one of the recommendations, in fact, from the respected Commission on Intellectual Property Rights (CIPR) study commissioned by the UK government on the intellectual property system in developing countries. See United Kingdom, Commission on Intellectual Property Rights (CIPR), Integrating Intellectual Property Rights and Development Policy, London, 2002. (http://www.iprcommission.org/papers/pdfs/ final_report/ciprfullfinal.pdf). See next chapter for a more detailed description on the recommendations of this Report prepared by the Chamber of Deputies' Center for Strategic Studies and Debate, in regard to which patentability requirement patterns must be applied. 
a) whether it is a policy based on the U.S., the European or Japanese model, without adjustments to the social-economic and technological reality of Brazil,

b) whether it is a policy that respects the international treaties signed by Brazil, but balanced enough to implement in the national legal framework the safeguards allowed by those treaties, with the aim of respecting other constitutionally established rights such as the fundamental rights and guarantees of access to health, to education, culture and information, as well as the patent clause in the Brazilian Constitution: to promote economic, social and technological development in Brazil.

For the Brazilian State to have a clear and unified policy concerning patent and related rights, we recommend that the Inter-ministerial Group, following the reformulations hereby presented, becomes the forum in charge of coordinating and unifying the decisions of the several organisms and entities of the Federal Executive Branch regarding patent and related rights, yielding necessarily binding resolutions. In other words, the resolutions adopted by the new Council will no longer be mere suggestions or opinions, but must be binding, consequently, adopted as the country's policy regarding intellectual property and related rights.

If there is a lack of coordination and unification of the position, there is a risk of an installed state of political and legal uncertainty, with potential economic and social consequences that can prove extremely detrimental to the Brazilian State - and could even be explored by foreign States, at our expense.

Presently, the GIPI is presided by the President of Camex and comprises 11 Ministries. Camex, in its turn, "is an organism that integrates the Government Council of the Presidency of the Republic and aims at formulating, adopting, implementing and coordinating policies and activities regarding the foreign trade of goods and services, including tourism." ${ }^{410}$ (emphasis added; translated from the original)

Camex consists on an organism of foreign trade, eminently. It deals with trade, from the international standpoint. Dealing with promotion of science and technological innovation per se is not among Camex's competencies. Let alone education and culture, or health. Camex's competency concerns commercial aspects, or rather, foreign trade. Camex is not competent, therefore, to deal with the promotion of science and technological innovation, or with education, culture, and health.

Thus, those intellectual property rights serve a specific purpose: to promote scientific, economic, cultural, technological and social progress. The purpose of patent rights, as well as other knowledge goods, is not commercial. The Constitutional patent clause is clear in that respect (Art. 5, XXIX), as are the goals and principles of the WTO 
TRIPs Agreement itself (Articles 7 and 8). Patents and knowledge goods are a means to promote the development of society. The generation of wealth and commerce are natural consequences, if those knowledge goods are well balanced, but their goal is scientific and technological progress - as well as cultural, in the case of copyright.

In that light, dealing with patents (promotion of science and technological innovation), copyright (culture and education) or patented medicines (health), under the coordination or within an organism that works towards the formulation, adoption, implementation and coordination of policies and activities concerning foreign trade does not appear to us prudent or appropriate.

Leaving the policy of knowledge goods under the coordination of Camex, a strictly commercial body, puts the decisions of the Federal Executive Branch regarding the patent system and knowledge goods in the country at risk of imbalance. There is the risk of not affording due discretion when analyzing other fundamental rights and guarantees provided in the Brazilian Constitution such as access to health, culture, education and related rights.

It does not appear to us that the Executive Branch intends to deal with the copyright of didactic books, so important for the promotion of education in Brazil, under the strategic coordination of an eminently commercial body. It does not appear to use either that the Executive Branch wants to deal with patented medicines, for instance, that directly affect the Government programs of access to health programs, within an eminently commercial scope.

According to the Ministry of Development, Industry and Foreign Trade (MDIC), the embryo of the present GIPI arose “in the midst of the 1980's, when there was a need for the coordination of government positions towards the negotiations of intellectual property in the Uruguay Round of GATT"411, which culminated in the creation of the WTO, of which the TRIPs Agreement is an integral part. "Pressured by the United States - that had determined unilateral commercial retaliations -, the Brazilian government decides to give in to all demands from the U.S. On a rite of perfection, the Patent Act $[\ldots]$ is written in English and then translated." ${ }^{12}$ Ironically, our present Patent Act was written in English, for foreign commercial interests.

411 See http://www.desenvolvimento.gov.br/sitio/interna/interna.php?area=3\&menu=1779. translated from the original.

412 See César Benjamin, "Lei de Patentes: Como o Brasil foi vencido", in Atenção, ano 2, n. 4, 1996. translated from the original. According to the Ministry of Development, Industry and Foreign Trade, by means of Inter-ministeriala Ordinance no. 346, of 1990, a commission was created to elaborate the Executive Branch bill aimed at altering the 1971 Patent Act, which resulted in Act 9.279, of 1996. In 1995 GIPI was consolidated in the III CAMEX Meeting. See http://www.desenvolvimento.gov.br/sitio/interna/interna. php?area $=3 \&$ menu=1779. (in Portuguese) 
As evident, the origins of GIPI themselves and their continued role that focuses on foreign trade cast light on the risks of bestowing the competency of coordination of such an important area in Brazil upon an organism with essentially commercial goals.

\section{Recommendations}

a) To the Executive Branch:

a.1) to the President's Office:

a.1.1) evaluate the convenience of signing the Decree proposed above, for the creation of the Council of Intellectual Property Rights CoDiPI, housed by the President's Office.

a.1.2) evaluate the convenience of making the new Council's resolutions binding.

\section{The Brazilian Patent Office (INPI): headquarters in the Federal District}

The Federal Law that created the Brazilian Patent Office (INPI), Law no. 5648 of 11 December 1970, establishes that the Office shall have its "headquarters and fora in the Federal District".

Its present headquarters are in the capital of the State of Rio de Janeiro, which is therefore, illegal.

The transfer of the Patent Office (INPI) to the Federal District has positive aspects, as well as negative. It is undeniable that Rio de Janeiro is a focal point of activities related to the operations of the Patent Office, such as specialized law practices and agents of industrial properties, as well as specialized Court Branches of the Federal Court. Over the last few years, the Brazilian Patent Office began to invest on new premises, as its headquarters building was in poor conditions. Those are the arguments in favor of keeping the Brazilian Patent Office in Rio de Janeiro.

On the other hand, public policy decisions cannot happen away from the Federal District. Bearing in mind that the patent system influences economic, technological and social development in the entire country, it makes no sense for the the Brazilian Patent Office to operate in any other locality but the Federal Capital. And that is precisely what is ordered by the Founding Act of the Brazilian Patent Office. 
In the beginning of the transition to the Federal Capital, the structure of examination, analysis and brand name registrations, patents, geographic indications, computer software and other competency areas of the Patent Office could remain in Rio de Janeiro, while the Presidency, the boards and the area coordination offices would be immediately transferred to the Federal District. As the years go by, further evaluation about the integral transference of the Brazilian Patent Office to the Federal District can be undertaken, as ordered by law.

The main goal of this proposal is not to enforce the Founding Act of the Brazilian Patent Office but to bring the decision-making activities closer to the Ministries that deal with the subjects related to industrial property rights, as well as to the Presidency of the Republic, in order to promote a policy convergent with national interests of scientific, technological, economic and social development in the country.

\section{Recommendations}

\section{a) To the President's Office:}

Consider issuing a Decree establishing that the Brazilian Patent Office's President, Directors, and area Coordinators shall exercise their functions from and in the country's capital, Brasília. 


\section{BIBLIOGRAPHY}

Abifina. Revista Facto, Ano V, No 30, Jul/Set, 2011.

"O impacto das importações no setor produtivo químico-farmacêutico do Brasil”. 2005. Available at <http://www.abifina.org.br/arquivos/abf_publicacoes/O_ Impacto.pdf>. Access: November 14, 2008.

" "Comitê de Propriedade Industrial, Patenteabilidade de polimorfos". 2007. Available at http://www.abifina.org.br/arquivos/POLIMORFISMO_Agosto_2007.pdf.

"A indústria farmoquímica no Brasil". Presentation to the Special Subcommittee for Pharmaceutical Assistance and other Inputs of the Chamber of Deputies' Social Security and Family Commission (Subcomissão Especial de Assistência Farmacêutica e outros Insumos da Comissão de Seguridade Social e Família da Câmara dos Deputados). June 2003. Available at <http://www.abifina.org. br/arquivos/abf_publicacoes/A_industria_farmo.pdf $>$. Access: November 14, 2008.

ABBOTT, Frederick M. “The JudgmentIn Novartisv. India: What The Supreme CourtOf India Said", in IP-Watch, Apr. 4, 2013, available at http://www.ip-watch.org/2013/04/04/ the-judgment-in-novartis-v-india-what-the-supreme-court-of-india-said/.

ABBOTT, Frederick M. and Reichman, Jerome H., "Doha Round's Public Health Legacy: Strategies for the Production and Diffusion of Patented Medicines under the Amended TRIPs Provisions", 10 J. Intl. Econ, L. 921, 2007.

AGROSOFT. Legislação trava pesquisas científicas e tecnológicas da biodiversidade. Edição de 12/08/2011.

ANGELL, Marcia. A verdade sobre os laboratórios farmacêuticos. Rio de Janeiro: Record, 2008.

ARBIX, Glauco. “Uma guerra global, um jogo de muitos bilhões", Valor, 11, 12, 13 e 14 de outubro de 2012, p. 11.

WORLD HEALTH ASSEMBLY. Resolution WHA61.21. Global strategy and plan of action on public health, innovation and intellectual property. In: The Sixty-first World Health Assembly, 19-24 May 2008.

BARBOSA, Denis Borges. Proposta para introduzir o uso público não comercial das patentes no direito brasileiro, 2010. Available at http://www.denisbarbosa.addr.com/ arquivos/200/economia/proposta_uso_patentes.pdf. Access: April 25, 2011.

.O papel da Anvisa na concessão de patentes. Available at http://denisbarbosa. addr.com/papelanvisa.pdf. 2009. 
"Inconstitucionalidade das patentes pipeline", 2006. Available at http://www. denisbarbosa.addr.com/arquivos/200/constitucional/pipeline.pdf.

“Usucapião de Patentes”. Rio de Janeiro: Lúmen Júris, 2006

BARBOSA, Pedro Marcos Nunes. A proteção dos dados de testes sigilosos submetidos à regulação estatal. Rio de Janeiro: Revista da EMARF, Volume 12, agosto 2009.

"O art. 40 da LPI como propulsor de uma patente perene", in Revista Facto - Associação Brasileira das Indústrias de Química Fina, Biotecnologia e suas Especialidades, 9a Edição, Setembro/Outubro 2007, available at http://www.abifina. org.br/factoNoticia.asp?cod=215.

BASSO, M. A Anvisa e a concessão de patentes farmacêuticas. Instituto de Tecnologia do Paraná (TECPAR) e Agência Paranaense de Propriedade Industrial (APPI). Available at http://www.deolhonaspatentes.org.br/media/file/Publicacoes/Basso_appi_itp_anvisa. pdf. 2004.

BENJAMIN, César. "Lei de Patentes: Como o Brasil foi vencido", in Atenção, ano 2, n. 4, 1996.

BRASIL, Nelson. Available at the document "Cronologia do desenvolvimento científico, tecnológico e industrial brasileiro - 1938-2003”, Brasília, Ministério do Desenvolvimento, Indústria e Comércio Exterior, 2005. Available at <http://www.desenvolvimento.gov.br/ arquivo/se/Cronologia1938_2003.pdf.

BUSS, P., Chamas, Claudia. Um novo modelo para a pesquisa em saúde global, Valor Econômico, 2012.

CANO, G.J. La producción y La transferencia de tecnologia: la protección de La propiedad Intelectual y el desarrollo sostenible en el contexto de La Conferencia CNUMAD 92. Revista del Derecho Industrial. Buenos Aires, n.41, p.373-388, 1992.

CARVALHEIRO, J.R. Os desafios para a saúde. Estud. Av., v.13, n.35, p.7-10, 1999.

CBD, "Nagoya Protocol on Access to Genetic Resources and the Fair and Equitable Sharing of Benefits Arising from their Utilization”, available at http://www.cbd.int/abs/ text/. Access: October 29, 2012.

CHANG, Ha-Joon. "Maus Samaritanos - mito do livre comércio e a história secreta do capitalismo", Rio de Janeiro: Elsevier, 2009.

"Intellectual property rights and economic development: historical lessons and emerging issues", TWN, 2001.

CHAVES, Gabriela Costa. Patentes farmacêuticas: por que dificultam o acesso a medicamentos?, org. Renata Reis et al.. Rio de Janeiro: ABIA, 2006. Available at http:// www.patentes.org.br/media/file/Publica\%C3\%A7\%C3\%B5es/cartilha_patentes.pdf 
COGHLAN, A. Biodiversity convention a 'lousy deal', says US. New Scientist. London, July 4, 1992. Available at http://www.newscientist.com/article/mg13518281.500biodiversityconvention-a-lousy-deal-says-us-.html

COHEN, Julie, e Lemley, Mark. "Patent scope and innovation in the software industry", California Law Review, Vol. 89, n. 1, Jan., 2001

COMITÊ NACIONAL DE BIOTECNOLOGIA - CNB. Ata da XIX Reunião; 29 de Novembro de 2011;

COMMISSION ON INTELLECTUAL PROPERTY RIGHTS. "Integrating intellectual property rights and developing policy", Report of the Commission on intellectual property rights, London, UK 2002. Available at http://www.iprcommission.org/papers/pdfs/final_ report/ciprfullfinal.pdf.

COMPARATO, Fabio Konder. "A transferência empresarial de tecnologia”, Volume 4 de Cadernos CEDEC: Centro de Estudos de Cultura Contemporânea (CEDEC), 1984.

CONTROLADORIA-GERAL DA UNIÃO (CGU), Processo: 52400.016890/2012-12, Relatório n 201203764.

CONVENTION ON BIOLOGICAL DIVERSITY (CDB). 1992. Available at http:// www.cbd.int/convention/convention.shtml.

CONVENTION ON BIOLOGICAL DIVERSITY (CDB), 2010. Nagoia Protocol on Access to Genetic Resources and the Fair and Equitable Sharing of Benefits Arising from their Utilization to the Convention on Biological Diversity. Available at http://www.cbd. int/decision/cop/?id=12267.

CONVENTION ON BIOLOGICAL DIVERSITY (CBD), 2011. List of Parties. Available at http://www.cbd.int/information/parties.shtml?tab=0. Access: March 15, 2011.

COSENZA, APF. O Uso Governamental das Patentes: Uma possibilidade para a Saúde Pública no Brasil. Dissertação de Mestrado, PPED/UFRJ, 2010.

CORREA, Carlos María. Towards a new model for pharmaceutical research. Bull World Health Organ [online]. 2012, vol.90, n.11.

. "Pharmaceutical Innovation, Incremental Patenting and Compulsory Licensing". Geneva, South Center, 2011, available at http://www.southcentre.org/index. php?option=com_docman\&task=doc_download\&gid=2071\&Itemid=182\&lang=en .

Guidelines for the examination of pharmaceutical patents: developing a public health perspective. 2007. p. 10-11. Available at http://www.iprsonline.org/resources/docs/ Correa_Patentability\%20Guidelines.pdf. 
Protection of Data Submitted for the Registration of Pharmaceuticals: Implementing theStandards of the Trips Agreement. South Centre, University of Buenos Aires and Department of Essential Drugs and Medicines Policy of the World Health Organization. 2002. Disponível em: http://www.who.int/medicines/areas/policy/ protection_of_data.pdf.

Implications of the Doha Declaration on the TRIPS Agreement and Public Health. Geneva: WHO; 2002.

DIMASI, J.A., Hansen, R. W., e Grabowski, H.G.. The price of innovation: New estimates of drug development costs. Journal of Health Economics 22, 151-185, 2003.

DIMASI, J. A., and Grabowski, H. G.. The cost of Biopharmaceutical RED: Is Biotech Different? Managrial and Decision Economics 28, 469-479, 2007.

DNDi - Drugs for Neglected Diseases initiative. "Transformando Sucessos Individuais em Mudanças Sustentáveis para Garantir a Inovação em Saúde para Pacientes Negligenciados: Por que é necessária uma convenção sobre P\&D essencial em saúde?”, 2012, available at http://www.dndi.org.br/images/stories/pdf/dndi_policy_port.pdf

DRAHOS, Peter; Braithwaite, John. "Information Feudalism: who owns the knowledge economy?”, The New Press, New York, 2003.

DUHIGG, Charles; Lohr, Steve. “The Patent, Used as a Sword”, New York Times, October 7, 2012. Available at https://www.nytimes.com/2012/10/08/technology/patentwars-among-tech-giants-can-stifle-competition.html?pagewanted=all\&_r=0

ECONOMIST, The. "Intellectual Property in Brazil: Owning Ideas - Getting Serious about Patents", November 3, 2012. Available at http://www.economist.com/news/ americas/21565606-getting-serious-about-patents-owning-ideas.

EU-China Project on the Protection of Intellectual Property Rights (IPR2), "Third Revision of China's Patent Law: Legal texts and documents on the drafting process 20062008”, 2010.

FAO. InternationalTreatyonPlantGeneticResourcesforFoodandAgriculture, disponível em: http://www.fao.org/Legal/treaties/033s-e.htm, 2011

FEDERAL TRADE COMMISSION. “The Evolving IP Market Place - Aligning Patent Notice and Remedies with Competition", 2011, available at www.ftc.gov/ os/2011/03/110307patentreport.pdf

"To promote innovation: the proper balance of competition and patent law and policy". 2003, disponível em: http://www.ftc.gov/os/2003/10/innovationrpt.pdf. 
"Generic drug entry prior to patent expiration: an FTC study". Washington, DC, United States Federal Trade Commission, July 2002. Available at http://www.ftc. gov/os/2002/07/genericdrugstudy.pdf

FIANI, R, Vater, C.. O debate econômico internacional da propriedade intelectual: aspectos relevantes para a saúde brasileira. R. Eletr. de Com. Inf. Inov. Saúde. Rio de Janeiro, v.3, n.4, p.180-190, Dec. 2009.

FURTADO, Gustavo Guedes. “Tranferência de Tecnologia no Brasil: Uma Análise de Condições Contratuais Restritivas”, Masters’ dissertation. Programa de Pós Graduação em Políticas Públicas, Estratégias e Desenvolvimento, Instituto de Economia, Universidade Federal do Rio de Janeiro, 2011.

GADELHA, C. Perspectivas do investimento em saúde. Rio de Janeiro: UFRJ, 2009.

GEYER, Carlos Alexandre, "Harmonização internacional: o futuro do tratado substantivo da Lei de Patentes e suas implicações para os países em desenvolvimento", comments made during the Patents, Innovation and Development International Seminar (Seminário Internacional Patentes, Inovação e Desenvolvimento-SIPID), held by Brazilian Association of Chemical and Biotechnology Industries and its Specialties (Associação Brasileira das Indústrias de Química Fina, Biotecnologia e suas Especialidades-Abifina), in 5 and 6 July 2007, in Rio de Janeiro, available at http://www. abifina.org.br/arquivos/II_sipid_3_hormonizacao.pdf.

GUISE, Mônica Steffen. "Comércio Internacional, Patentes e Saúde Pública”, dissertation submitted to the Federal University of Santa Catarina (Universidade Federal de Santa Catarina), Post-Graduate Law, Area of Concentration in International Relations, to obtain a Master's degree in Law, Florianópolis, 2006.

GRAU, Eros Roberto, et. al., "Por um Brasil Inovador: Estudo da FGV e USP contra a Concessão de Patentes para Programas de Computador no Brasil”, p. 17, available at http://observatoriodainternet.br/wp-content/uploads/2012/05/Estudo-Patentes-deSoftware-USP-FGV.pdf

GRUPO DE TRABALHO SOBRE PROPRIEDADE INTELECTUAL - GTPI (Working Group on Intellectual Property). Letter to the Brazilian Minister of Health concerning a shortage of atazanavir medicine, 2011, available at http:// www.deolhonaspatentes.org.br/media/file/Notas\%20GTPI\%20-\%202011/Carta\%20 sobre\%20desabastecimento\%20do\%20Atazanavir.pdf.

GUIMARÃES, R; SOUZA, LEPF; SANTOS, LMP; SERRUYA, S. Não há saúde sem pesquisa: avanços no Brasil de 2003 a 2010. Revista Baiana de Saúde Pública v.36(1), JanMar. 2012. 
HARGREAVES, Ian. "Digital Opportunity. A Review of Intellectual Property and Growth. An Independent Report by Professor Ian Hargreaves”, May 2011, available at www.ipo.gov.uk/ipreview-finalreport.pdf.

HASENCLEVER, Lia; Lopes, Rodrigo; Chaves, Gabriela Costa; Reis, Renata; Vieira, Marcela Fogaça. "O Instituto de patentes pipeline e o acesso a medicamentos: aspectos econômicos e jurídicos deletérios à economia da saúde”. In Revista de direito Sanitário, São Paulo v. 11, n 2 p. 164-188, Jul/Oct.2010.

HELFER, Laurence; Austin, Graeme. "Human Rights and Intellectual Property: Mapping the Global Interface”, Cambridge, 2011.

HÖGBERG LD, HEDDINI A, CARS O. The global need for effective antibiotics: challenges and recent advances. Trends Pharmacol Sci. 2010 nov. 31(11): 509-15.

HUNT, P. Neglected diseases: a human rights analysis. Special Topics in Social, Economic and Behavioural Research Series: n. 6. World Health Organization, 2007.

JAFFE, Adam B., e Lerner, Josh. "Innovation and Its Discontents - How our Broken Patent System is Endangering Innovation and Progress, and What to Do About it", Princeton, 2004.

JANNUZZI, Anna Haydée Lanzillotti; Vasconcellos, Alexandre Guimarães; Souza, Cristiana Gomes de. Especificidades do patenteamento no setor farmacêutico: modalidades e aspectos da proteção intelectual. Cadernos de Saúde Pública, Rio de Janeiro, 24(6): 1205-1218. June 2008.

KAMDAR, Adi e NAZER, Daniel. "Deep Dive: Software Patents and the Rise of Patent Trolls", February 28, 2013. Available at https://www.eff.org/deeplinks/2013/02/ deep-dive-software-patents-and-rise-patent-trolls.

KHADER, Feroz Ali. "The Law of Patents - With a Special Focus on Pharmaceuticals in India", LexisNexis Butterworths, 2007.

LIGHT DW, Lexchin JR. Pharmaceutical research and development: what do we get for all that money? BMJ 2012; 345.

LOVE, James. Access to Medicine and Compliance with the WTO TRIPS Accord: Models For State Practice In Developing Countries. In Drahos, Peter e Mayne, Ruth (ed.). Global Intellectual Property Rights: knowledge, access, and development. Palgrave Macmillan, 2002.

MARIOT, G. Conhecimento tradicional e sistema da proteção da propriedade intelectual. Available at http://www.mbek.com.br/artigos/Conhecimento_tradicional.pdf

MASKUS, Keith, e Reichman, Jerome H., "International Public Goods and Transfer of Technology - Under a Globalized Intellectual Property Regime”, Cambridge University Press, 2005. 
MASNIK, Mike. "Why the Answer to Smartphone Patent Thickets is not a Patent Pool", Techdirt, 29.10.2010, available at https://www.techdirt.com/ articles/20101028/09595211635/why-the-answer-to-the-smartphone-patent-thicket-isnot-a-patent-pool.shtml

MELO, Milena Barbosa de; Barros, Lucília Napoleão. Os Direitos de Propriedade Intelectual e o Evergreening. In: Âmbito Jurídico, Rio Grande, 93, 01/10/2011, available at http://www.ambito-juridico.com.br/site/index.php?n_link=revista_artigos_ leitura\&artigo_id=10459. Access: April 3, 2012.

MENDOZA Ruiz, Adriana; Osório-de-Castro, Claudia Garcia Serpa. Medicamentos: falando de qualidade; org. Gabriela Costa Chaves et al., Rio de Janeiro: ABIA, 2008. p. 25. Available at http://www.abiaids.org.br/_img/media/Cartilha_Medicamentos.pdf.

MERCOSUR, Meeting of Ministers of Health, Agreement MERCOSUR/RMS/ ACORDO No 09/09.

MINISTÉRIO DAS RELAÇÕES EXTERIORES (MRE), nota 41, de 02.02.2011, "Assinatura do Protocolo de Nagoia sobre Acesso e Repartição de Benefícios", available at http://www.itamaraty.gov.br/sala-de-imprensa/notas-a-imprensa/assinatura-do-protocolode-nagoia-sobre-acesso-e-reparticao-de-beneficios. Access: October 29, 2012.

MINISTÉRIO DO DESENVOLVIMENTO, INDÚSTRIA E COMÉRCIO EXTERIOR (MDIC), Brasília, DF. Available at http://www.mdic.gov.br/arquivos/ dwnl_1325680533.pdf

MOON S, Bermudez J, 't Hoen, Ellen. Innovation and Access to Medicines for Neglected Populations: Could a Treaty Address a Broken Pharmaceutical RGD System? PLoS Med 9(5), 2012.

MORAIS, G. Acesso a Biodiversidade - Panorama Legal no Brasil. Apresentação realizada no Morel, Carlos. The road to recovery. Outlook neglected diseases. Nature, vol. 449, 2007.

MULLIN, Joe. "Even Obama knows patent trolls are "extorting" money", Ars Technica, February 14, 2013, available at http://arstechnica.com/tech-policy/2013/02 even-obama-knows-patent-trolls-are-extorting-money/.

NEW, William. "WTO General Council Extends Deadline For TRIPS Health Amendment", 01.12.2011, available at http://www.ip-watch.org/2011/12/01/wto-generalcouncil-extends-deadline-for-trips-health-amendment/. Access: October 29, 2012.

NUNES, António José Avelã et al. "A inconstitucionalidade das patentes 'pipeline’ brasileiras", in Revista Eletrônica do Instituto Brasileiro de Propriedade Intelectual (IBPI), Patentes Pipeline, edição especial, novembro de 2009, available at http://www. wogf4yvlu.homepage.t-online.de/media/155123c1662385b4ffff819cacl44221.pdf. 
OLIVEIRA, Marcos. "Medicamentos essenciais e licenças governamentais". Facto Abifina, edição n ${ }^{\circ}$ 5, jan/fev 2007. Available at http://www.abifina.org.br/factoNoticia. asp?cod=169.

OLIVEIRA, Rodrigo Borges. "A patenteabilidade do segundo e dos posteriores usos médicos no Brasil". Doctorate Thesis. Post-Graduation Program in Public Policies, Strategies and Development, Institute of Economy, Rio de Janeiro Federal University (Programa de Pós Graduação em Políticas Públicas, Estratégias e Desenvolvimento, Instituto de Economia, Universidade Federal do Rio de Janeiro), 2012. Available at http://www.ie.ufrj.br/images/pos-graducao/pped/defesas/Tese_-_Rodrigo_Borges_-_ Verso_Final_com_ficha_catalogrfica_-_Ps_-defesa.pdf.

PARK, Chan, and PRABHALA, Achal. “TRIPs flexibilities, access to medicines and the domestic pharmaceutical industry in South Africa: An analysis of patents, competition and medicines law", United Nations Development Programme, Regional Service Centre for Southern \& Eastern Africa, Nov. 2007.

PRABHALA, Achal \& Krishnaswamy, Sudhir. "Why Novartis case will help innovation”, in The Hindu, Apr. 15, 2013, available at http:/www.thehindu.com/opinion/lead/whynovartis-case-will-help-innovation/article4617473.ece.

. “The Law That Saved a Billion Lives", in Open, May 4, 2013, available at http://www.openthemagazine.com/article/nation/the-law-that-saved-a-billion-lives.

WORLD INTELLECTUAL PROPERTY ORGANIZATION (WIPO), "Agreement between the United Nations and the World Intellectual Property Organization", available at http://www.wipo.int/treaties/en/agreement/index.html. Access: October 29, 2012.

WORLD HEALTH ORGANIZATION (WHO). Research and development to meet health needs in developing countries: strengthening global financing and coordination. Report of the Consultative Expert Working Group on Research and Development: Financing and Coordination. Geneva: World Health Organization; 2012.

UNITED NATIONS (UN). Promotion and protection of all human rights, civil, political, economic, social and cultural rights, including the right to development. Report of the Special Rapporteur on the right of everyone to the enjoyment of the highest attainable standard of physical and mental health, Anand Grover. Genebra: UN, 2009. $\mathrm{A} / \mathrm{HRC} / 11 / 12$.

WORLD TRADE ORGANIZATION (WTO), “The Agreement on Trade-Related Aspects of Intellectual Property Rights",1994, available at http://www.wto.org/english/ tratop_e/trips_e/t_agm0_e.htm.

, "Members accepting amendment of the TRIPS Agreement", available at https:// www.wto.org/english/tratop_e/trips_e/amendment_e.htm. Access: October 29, 2012. 
"Members and Observers", available at https://www.wto.org/english/ thewto_e/whatis_e/tif_e/org6_e.htm. Access: October 29, 2012.

, "Implementation of paragraph 6 of the Doha Declaration on the TRIPS Agreement and public health - Decision of the General Council of 30 August 2003", General Council, WT/L/540 and Corr.1, September 1, 2003, available at https://www. wto.org/english/tratop_e/trips_e/implem_para6_e.htm. Access: October 29, 2012.

"Understanding the WTO: the Organization -MembersandObservers", 2008, available at http://www.wto.org/english/thewto_e/whatis_e/tif_e/org6_e.htm. Access: March 15, 2011.

, Briefing note on access to medicines. Data excludability and other TRIPs plus measures. 2006. Available at http://www.searo.who.int/LinkFiles/Global_Trade_ and_Health_GTH_No3.pdf

PARK, Chan. PARK, Chan. Challenging pharmaceutical patents: the case of India. p. 107. In WORLD HEALTH ORGANIZATION. Regional Office for South-East Asia. Intellectual property and access to medicines: papers and perspectives. India, 2010, pp. 108109. Available at http://apps.who.int/medicinedocs/documents/s1752len/s1752len.pdf.

PLAHE, J.K.; NYLAND, C. The WTO and patenting of lifeforms: policy options for developing countries.London, Third World Quarterly, v. 24, n.1, pp. 29-45, 2003.

REICHMAN, Jerome H. "Intellectual Property in the Twenty-First Century: Will the Developing Countries Lead or Follow?”, Houston Law Review, Vol. 46, No. 4, 2009

UNITED KINGDOM, Gowers Review of Intellectual Property, report by the Government of the United Kingdom, 2006.

Commission on Intellectual Property Rights (CIPR), CIPR Report "Integrating Intellectual Property Rights and Development Policy", London, 2002, available at http://www.iprcommission.org.

REIS, Renata, "Panorama Patentário dos Medicamentos Antirretrovirais no Brasil”. Doctorate Thesis in progress. Post-Graduation Program in Public Policies, Strategies and Development, Institute of Economy, Rio de Janeiro Federal University (Programa de Pós Graduação em Políticas Públicas, Estratégias e Desenvolvimento, Instituto de Economia, Universidade Federal do Rio de Janeiro), 2012.

REVISTA CONSULTOR JURÍDICO. Available at file:///F:/Propriedade\%20 Intelectual/Desafios\%20em\%20PI/Anvisa-INPI_CONJUR.htm. 2011

RØTTINGEN, JA; Buss, P; Davies, S \& Touré, O. Global-health research architecture-time for mergers? The Lancet. s 193- 195, 2009. 
RØTTINGEN J-A, Chamas, Claudia. A New Deal for Global Health RఠD? The Recommendations of the Consultative Expert Working Group on Research and Development (CEWG). PLoS Med 9(5), 2012.

SAEZ, Catherine. "WTO: Wide Support For LDC TRIPS Extension, With A Hitch”, IP-Watch, 06.03.2013, available at http://www.ip-watch.org/2013/03/06/ wto-wide-support-for-ldc-trips-transition-extension-with-a-hitch!.

SALOMÃO Filho, Calixto. Direito industrial, direito concorrencial e interesse público. Revista de Direito Público da Economia, Belo Horizonte, ano 2, n. 7, 2.004

SECRETARIAT OF THE CONVENTION ON BIOLOGICAL DIVERSITY. Sustaining life on earth. How the Convention on Biological Diversity promotes nature and human well-being. Secretariat of the Convention on Biological Diversity, Apr. 2000. Available at http://www.cbd.int/doc/publications/cbd-sustain-en.pdf.

SHADLEN, K.C. The Rise and Fall of "Prior Consent" in Brazil. The WIPO Journal: Analysis of Intellectual Property Issues.Vol3, Issuel, 2011.

SILVA, F.; ESPINDOLA, L. Access legislation on genetic resources patrimony and traditional knowledge. Revista Brasileira de Farmacognosia; 21(1): Jan./Feb. 2011.

SIMMONS, P.J. Learning to live with NGOs. Foreign Policy. Washington D.C., n.112, pp.82-96, 1998.

SOARES, Jaqueline Mendes; CORREA, Marilena Cordeiro Dias Villela; LAGE, Liane Elizabeth Caldeira. Patentes de Formas Polimórficas na Área de Fármacos no Brasil e o Impacto na Saúde Pública. RECIIS - R. Eletr. de Com. Inf. Inov. Saúde. Rio de Janeiro, v.4, n.2, p.43-52, Jun., 2010.

SOCIETY FOR ECONOMIC AND SOCIAL STUDIES, Public Health Safeguards in the Indian Patents Act and Review of Mailbox Applications. New Delhi, Society for Economic and Social Studies, set.2007.

SHAVELL, S., e TANGUY VY. "Rewards Versus Intellectual Property Rights," Journal of Law and Economics, v44, 02, Oct, 2001, 525-547.

RAGAVAN, Srividhya, e KHADER, Feroz Ali. "Proof of Progress: The Role of the Obviousness Standard in the Indian Patent Office”, Global Perspectives on Patent Law, 2012.

STIGLITZ, Joseph. "Scrooge and Intellectual Property Rights: A Medical Prize Fund Could Improve the Financing of Drug Innovations", 333 British Medical Journal 1279, 1279-80, 2006.

Knowledge as a global public good. In: Kaul I, Grunberg I, Stern MA, editors.

Global public goods: international cooperation in the 21st century. New York: Oxford University Press; 1999. 
TEMPORÃO, J. G.. O complexo industrial da saúde: público e privado na produção e consumo de vacinas no Brasil. Doctorate Thesis, Rio de Janeiro: Universidade do Estado do Rio de Janeiro, 2002 (Rio de Janeiro State University).

UNCTAD-ICTSD. Resource book on TRIPs and development. London, Cambridge University Press, 2005.

UNITED NATIONS. COMMISSION ON HUMAN RIGHTS. "Access to medication in the context of pandemics such as HIV/AIDS". E/CN.4/RES/2001/33. Available at http://ap.ohchr.org/documents/E/CHR/resolutions/E-CN_4-RES-2001-33.doc.

UNITED NATIONS. Committee on Economic, Social and Cultural Rights. General Comment $n$. 17. The right of everyone to benefit from the protection of the moral and material interests resulting from any scientific, literary or artistic production of which he or she is the author (art. 15). par. 35. Available at http://daccess-dds-ny.un.org/doc/ UNDOC/GEN/G08/422/35/PDF/G0842235.pdf?OpenElement.

UNITED NATIONS. SUBSTANTIVE ISSUES ARISING IN THE IMPLEMENTATION OF THE INTERNATIONAL COVENANT ON ECONOMIC, SOCIAL AND CULTURAL RIGHTS. Follow-up to the day of general discussion on article 15.1 (c), Monday, 26 November 2001. Human rights and intellectual property. Statement by the Committee on Economic Social and Cultural Rights. E/C.12/2001/15, par. 12. Available at http://www.unhchr.ch/tbs/doc.nsf/0/lelf4514f8512432cl256ba6003 b2cc6/\$FILE/G0146641.pdf

UNITED NATIONS HIGH COMMISSIONER FOR HUMAN RIGHTS. "Intellectual property rights and human rights. Sub-Commission on Human Rights Resolution 2000/7". Available at http://www.unhchr.ch/Huridocda/Huridoca.nsf/0/c4 62b62cf8a07bl3cl2569700046704e?Opendocument.

UNITED NATIONS CONFERENCE ON TRADE AND DEVELOPMENT (UNCTAD). Using Intellectual Property Rights to Stimulate Pharmaceutical Production in Developing Countries: A Reference Guide. New York and Geneva, 2011. Available at http://unctad.org/en/Docs/diaepcb2009d19_en.pdf

UNITED NATIONS CONFERENCE ON TRADE AND DEVELOPMENT (UNCTAD). The TRIPs Agreement and developing Countries, UNCTAD/ITE/1, New York and Geneva. 1996.

UNITED NATIONS DEVELOPMENT PROGRAMME (UNDP). Good practice guide: improving access to treatment by utilizing public health flexibilities in the WTO TRIPs Agreement. New York, 2010. 
United States Patent and Brand name Office - USPTO, "Interim Guidance for Determining Subject Matter Eligibility for Process Claims in View of Bikski v. Kappos", available at http://www.uspto.gov/patents/law/exam/bilski_guidance_27jul2010.pdf

USTR. USTR Special 301 Report. 2001. Washington D.C.

UPOV, Members of the International Union for the Protection of New Varieties of Plants, 2011, available at http://www.upov.int/export/sites/upov/members/en/pdf/pub423.pdf.

VIEIRA, Marcela Cristina Fogaça. "Proteção patentária para produtos e processos farmacêuticos: a questão da constitucionalidade das patentes pipeline". Monograph of completion of the lato sensu Post-Graduate Course in Intellectual Property Law and the New Information Technologies. Fundação Armando Álvares Penteado - FAAP. 2010.

VÉLEZ, E. Brazil's Practical Experience with Access and Benefit Sharing and the Protection of Traditional Knowledge. ICTSD Project on Genetic Resources. Policy Brief Number 8. Jun 201.

VILLARES, Fábio (org.). Propriedade intelectual: tensões entre o capital e a sociedade. São Paulo: Paz e Terra, 2007.

WATAL, Jayashree, "Intellectual Property Rights in the WTO and Developing Countries", Oxford, New Delhi, 2003.

WORLD HEALTH ORGANIZATION (WHO). Briefing note: access to medicines. Data excludability and other TRIPs-plus measures. March 2006. Available at http://www.wpro. who.int/hiv/documents/docs/BriefingNote2DataexcludabilityMarch2006_47A0.pdf.

WORLD HEALTH ASSEMBLY. Intellectual property rights, innovation and public health. WHA56.27. 28 May 2003. Available at http://apps.who.int/gb/archive/ pdf_files/WHA56/ea56r27.pdf.

WORLD MEDICAL ASSOCIATION- WMA Declaration of Helsinki - Ethical Principles for Medical Research Involving Human Subjects. Available at http://www. wma.net/en/30publications/10policies/b3/. 


\title{
ANNEX I
}

\section{Bill no. H.R. 5402/2013}

(Dr. Newton Lima, and Dr. Rosinha)

\begin{abstract}
Amends the Patent Act no. 9279/96, of 14 May 1996, to revoke the sole paragraph of Art. 40, modify Articles 10, 13, 14, 31, 195 and 229-C, and add Articles 31-A and 43-A; and amends Article 7 of Law no. 9782, of 26 January 1999.
\end{abstract}

The National Congress enacts:

Art. 1. This law revokes the sole paragraph of Art. 40; amends Articles 10, 13, 14, 31, 195 and 229-C; and adds Articles 31-A and 43-A, all in Law no. 9279/96, of 14 May 1996; and amends Art. 7 of Law no. 9782, of 26 January 1999.

Art. 2. The sole paragraph of Art. 40 of Law no. 9279 of 14 May 1996 is revoked.

[Sole Paragraph. The term shall not be less than 10 (ten) years for patents and 7 (seven) years for a utility model, beginning on the date of granting, unless the INPI has been prevented from examining the merits of the application by a proven pending judicial dispute or for reasons of force majeure.]

Art. 3. Articles 10, 13, 14, 31, 195 and 229-C of Law no. 9279 of 14 May 1996 shall be amended as follows:

"Art. 10. [The following are not considered to be inventions or utility models:]

$\mathrm{X}$ - any new property or new use of a known substance, or the mere use of a known process, unless this known process results in a new product;

$\mathrm{XI}$ - new forms of known substances that do not result in an improvement in the known efficacy of the substance.

Sole paragraph. For the purposes of this Article, salts, esters, ethers, polymorphs, metabolites, pure form, size of particles, isomers, mixtures of isomers, complexes, combinations and other derivatives of a known substance shall be considered the same substance, unless they significantly differ in terms of properties regarding efficacy." (new text) 
"Art. 13. The invention carries inventive activity when, for a person skilled in the art, it does not derive in an obvious or evident manner from the state of the art, and provided it represents a significant technical advance in regards to the state of the art." (new text) "Art. 14. The utility model carries inventive activity when, for a person skilled in the art, it does not derive in a common or vulgar fashion from the state of the art, and provided it represents a technical advance in regards to the state of the art." (new text)

"Art. 31. From the publication of the patent application until the end of the exam, any interested party may file an opposition.

$\$ 1$ The applicant shall be notified of the opposition through publication in the official gazette, and may respond within 60 days from the publication of the opposition.

$\$ 2$ In cases where an opposition to a patent application is filed, the Brazilian Patent Office may commission technical opinions from the Public Administration, from organizations recognized by the Government as consultancy bodies, and from university professors and students.

$\$ 3$ After the opposition is filed, the examiner may, upon justified demand, application any additional clarification he/she deem necessary, as well as the presentation of supplementary documents.

$\$ 4$ The examiner shall mandatorily respond to each filed opposition, indicating the reason by which he/she accepts or rejects the arguments presented. ." (new text)

“Art. 195. [A crime of unfair competition is perpetrated by anyone who:]

[XIV. divulges, exploits, or utilizes, without authorization, results of tests or other undisclosed data whose preparation involves considerable effort and that were submitted to government agencies as a condition for obtaining approval to commercialize products.]

$\$ 3$ The provision set forth under item XIV does not apply to the use, by government bodies, of test results or other undisclosed data, for market approval of products equivalent to the product for which they were initially presented." (new text)

"Art. 229-C. The granting of patents for pharmaceutical products and processes shall depend on the prior consent from the National Sanitary Agency - ANVISA, that shall examine the object subject to the patent application in light of public health.

$\S 1$ A patent application shall be considered as contrary to public health, according to further regulation, where: 
I - the product or pharmaceutical process in the patent application present a health risk, or

II - the patent application for pharmaceutical product or pharmaceutical process is of interest to an access to medicines policy or to a pharmaceutical care program under the National Health System - SUS, and provided that it does not meet the patentability requirements and the other criteria established by this law.

$\$ 2$ Following the prior consent examination and after the decision is published, ANVISA shall return the application to the Patent Office, that shall examine the approved application, and definitely archive the application that has not been approved." (new text)

Art. 4. Articles 31-A and 43-A shall be added to Law no. 9279 of 14 May 1996:

Art. 31-A. The Brazilian Patent Office shall offer an intuitive electronic channel, of easy access, connected to the Internet, for any person to present, free of charge, evidence or proof of previous existence, in Brazil or abroad, of the related invention or state of the art.

Sole paragraph. It shall be allowed the presentation of evidence or proof of prior existence, in Brazil or abroad, of the related invention or state of the art, even after a patent is granted, and especially during the opposition and the post-grant opposition procedures.

Art. 43-A. The Government, by Ordinance from the Minister of State concerned, may use the subject matter of a patent or of a patent application, for non-commercial purposes, without consent or authorization from the patent holder or patent applicant, directly or upon contract or authorization to third parties, for public interest purposes, including national defense and social interest.

$\S 1$ Should the invention be a process, the public non-commercial use of the patent or patent application shall include the use in relation to any product that may be obtained by the process that is protected by the patent or the patent application;

$\$ 2$ The Government shall notify the patent holder or patent applicant upon public noncommercial use;

$\S 3$ Public non-commercial uses shall meet the following conditions:

I - not hinder the full exercise of the other rights of the patent holder or patent applicant;

II - be non-exclusive, and not admit sub-licensing;

III - be undertaken exclusively to serve the goals of the Ordinance that authorized it, resting assured that any other use that, without the character of public non-commercial use, would constitute an infringement of Art. 42 of this Act, is hereby prohibited; 
$\$ 4$ The remuneration for public non-commercial use shall be set by the Government, taking into account the circumstances of each use, shall take into account the percentage that would customarily incur upon a voluntary license between independent parties, applied over the cost for the Government resulting from the use of the subject matter of a patent or patent application, and weighed according to the collaboration supplied by the patent holder in the transfer of technology;

$\S 5$ In the case of patent applications, the remuneration shall be legally deposited until the granting of the patent;

$\S 6$ The Judiciary shall not, in regards of public non-commercial use, decide whether public interest purposes apply;

$\S 7$ Public non-commercial uses shall not be lifted, limited or interrupted by legal appeal over the appointed remuneration.

Art. 5. Article 7 of Law no. 9782 of 26 January 1999 shall be amended as follows:

"Art. 7. [The Sanitary Agency shall implement and enforce the provisions set forth under sections II through VII of Art. 2 of this Law, and the Agency shall:]

XXVIII - participate in the process of examination of patent applications for pharmaceutical products and processes, including the analysis of the patentability requirements and the other criterion set forth under the specific legislation.

Art. 6. This law shall come into force within one hundred and twenty (120) days from the date of its publication. 


\section{ANNEX II}

PRESIDENTIAL DECREE No.

2013

Creates, under the President's Office, the Council of Intellectual Property Rights CoDiPI; extinguishes the Inter-ministerial Group on Intellectual Property - GIPI, linked to the Chamber of Foreign Trade - CAMEX; and revokes the Decree of 21 August 2001, which creates GIPI.

The PRESIDENT OF THE REPUBLIC, in the use of her attributions conferred by Article 84, caput, item VI, “a”, of the Constitution, DICTATES:

Art. 1. The Council of Intellectual Property Rights [Conselho de Direitos de Propriedade Intelectual - CoDiPI] is hereby created under the President's Office.

Art. 2. Considering the social interest and the country's technological, scientific, cultural, educational and economic development, CoDiPI shall:

I - provide stock for the definition of guidelines for the policy of intellectual property rights and related matters;

II - propose the planning for a coordinated action of the bodies in charge of the implementation of the aforementioned policy;

III - issue its resolution beforehand regarding the norms, guidelines and legislation for intellectual property rights and related matters;

IV - appoint technical parameters for bilateral and multilateral negotiations on intellectual property rights and related matters;

$\mathrm{V}$ - propose a coordinated government action directed at the conciliation of internal and external policies;

VI - provide stock on intellectual property rights and related matters towards the formulation and implementation of other public policies;

VII - promote inter-ministerial coordination on subjects tackled by CoDiPI; 
VIII - consult with academic institutions of higher learning, with the private sector and non-governmental organizations on intellectual property rights issues and related matters; and

IX - instruct and report on matters concerning intellectual property rights and related matters.

Art. 3. CoDiPI shall be comprised of representatives from the following government bodies:

I - Chief of Staff of the President's Office, who shall be CoDiPI's president;

II - Ministry of Science, Technology and Innovation;

III - Ministry of Development, Industry and Foreign Trade;

IV - Ministry of Culture;

$\mathrm{V}$ - Ministry of Foreign Affairs;

VI - Ministry of Health;

VII - Ministry of Agriculture, Livestock and Food Supply;

VIII - Ministry of Education;

IX - Ministry of Treasury;

X - Secretariat of Strategic Affairs of the Presidency of the Republic;

XI - Ministry of Environment; and

XII - Ministry of Justice.

$\S 1$ The Brazilian Patent Office - INPI, the National Sanitary Agency - ANVISA, the Competition Body - CADE, the Brazilian Council for Genetic Heritage Management - CGEN, the Brazilian Institute of the Environment and Renewable Natural Resources - IBAMA, or any other body or entity of the Public Administration, may be heard whenever the subject matter lies within their sphere of competence.

$\$ 2$ Representatives of other bodies or Public Administration entities as well as field experts may be invited to participate on CoDiPI meetings, in accordance to its regulation.

Art. 4. CoDiPI shall deliberate in plenary sessions, with the possibility of setting up thematic subgroups whenever it is necessary.

$\$ 1$ Both the meetings of thematic subgroups and non-deliberative plenary sessions may have the participation of other members of the Ministries appointed in Article 3, provided that the President of CoDiPI is notified in advance, in accordance to its regulation. 
$\$ 2$ CoDiPI shall deliberate through binding resolutions, by simple majority, fulfilling the minimum quota of two thirds of its members, with the casting vote held by the President.

$\$ 3$ CoDiPI shall establish its regulation and complementary norms, that shall be approved by absolute majority.

$\$ 4$ The ordinary deliberative meetings of the Council shall be called upon with a minimum of 10 days in advance.

Art. 5. The Executive Secretariat of CoDiPI shall be exercised in accordance to its regulation.

Art. 6. The formulation and implementation of legal norms, guidelines or international instruments on intellectual property rights and related matters by government bodies shall be evaluated and previously approved by CoDiPI, by means of a resolution.

Art. 7. The Inter-ministerial Group on Intellectual Property - GIPI, linked to the Chamber of Foreign Trade - Camex, shall be extinct.

$\S 1$ The decisions adopted by GIPI shall remain in force.

$\S 2$ CoDiPI shall restore ongoing discussions at GIPI.

Art. 8. The Decree of 21 August 2001, that created GIPI, shall be revoked.

Art. 9. This Decree comes into force at the date of its publication. 


\title{
ANNEX III
}

\section{LAW No. 9279, OF MAY 14, $1996^{413}$}

\author{
Regulates Rights And Obligations Regarding \\ Industrial Property.
}

The President of the Republic

Let it be known that the National Congress decrees and I sanction the following Law:

\section{PRELIMINARY PROVISIONS}

1. This Law regulates rights and obligations regarding industrial property.

2. The protection of industrial property rights, considering the social interest and the technological and economic development of this country, is afforded by means of:

I - the granting of invention and utility model patents;

II - the granting of a registration of an industrial design;

III - the granting of a registration of a trademark;

IV - the repression of false geographical indication; and

$\mathrm{V}$ - the repression of unfair competition.

3. The provisions of this Law also apply to:

I - applications for patents or for registrations originating from abroad and filed in this country by a party that enjoys protection under a treaty or convention in force in Brazil; and

II - to nationals of or persons domiciled in a country that assures Brazilians or persons domiciled in Brazil reciprocity of equal or equivalent rights.

4. The provisions of treaties in force in Brazil are equally applicable to natural and legal persons who are nationals of or domiciled in this country.

5. For legal effects, industrial property rights are deemed to be movable property.

\section{TITLE I PATENTS}

\section{CHAPTER I}

OWNERSHIP

6. It shall be assured to the author of an invention or a utility model the right to obtain a patent that guarantees his property, under the conditions established in this Law.

413 Source: WIPO, available at http://www.wipo.int/wipolex/en/details.jsp?id=515 
(1) In the absence of proof to the contrary, the applicant is presumed to be legitimately entitled to obtain the patent.

(2) A patent may be applied for in the author's own name, by the heirs or successors of the author, by the assign or by whomever the law or the employment or services contract determines to be the owner.

(3) In the case of an invention or utility model created jointly by two or more persons, the patent may be applied for by all or any of them, by means of naming and identifying the others, to safeguard the respective rights.

(4) The inventor shall be named and identified, and may application that his name not be disclosed.

7. If two or more authors have created the same invention or utility model, acting independently of each other, the right to obtain the patent shall be assured to the one who proves the oldest filing date, regardless of the dates of invention or creation.

Sole Paragraph. The withdrawal of an earlier filing before it has produced any effect shall confer priority on the immediately subsequent filing.

\section{CHAPTER II}

\section{PATENTABILITY}

\section{Section I}

\section{Patentable Inventions and Utility Models}

8. An invention is patentable if it satisfies the requirements of novelty, inventive step, and industrial application.

9. An object of practical use, or part thereof, is patentable as utility model if it is susceptible of industrial application, has a new form or arrangement, and involves an inventive act, that results in functioning improvement in its use or manufacture.

10. The following are not considered to be inventions or utility models:

I - discoveries, scientific theories, and mathematical methods;

II - purely abstract conceptions;

III - commercial, accounting, financial, educational, advertising, raffling, and inspection schemes, plans, principles or methods;

IV - literary, architectural, artistic and scientific works, or any aesthetic creation;

$\mathrm{V}$ - computer programs perfse;

VI - presentation of information;

VII - rules of games;

VIII - surgical techniques and methods, as well as therapeutic or diagnostic methods, for application to human or animal body; and 
IX - all or part of natural living beings and biological materials found in nature, even if isolated therefrom, including the genome or germoplasm of any natural living being, and the natural biological processes.

11. An invention and a utility model are considered to be new if they are not part of the state of the art.

(1) The state of the art consists of everything that became accessible to the public prior to the filing date of the patent application, by means of a written or oral description, by use or by any other means, in Brazil or abroad, except as provided in Articles 12, 16, and 17.

(2) For the purposes of determining novelty, the entire content of an application filed in Brazil, and not yet published, shall be considered to be state of the art from the date of filing or of claimed priority, provided that it comes to be published, even subsequently.

(3) The provisions of the preceding Paragraph shall apply to an international patent application filed according to a treaty or convention in force in Brazil, provided that there is national processing.

12. The disclosure of an invention or utility model shall not be considered to be state of the art if it occurred during the 12 (twelve) months preceding the date of filing or of priority of the patent application, if made:

I - by the inventor;

II - by the Instituto Nacional da Propriedade Industrial-INPI (National Institute of Industrial Property), by means of official publication of the patent application filed without the consent of the inventor, based on information obtained from him or as a consequence of actions taken by him; or

III - by third parties, based on information obtained directly or indirectly from the inventor or as a consequence of actions taken by him.

Sole Paragraph. The INPI may require from the inventor a statement related to the disclosure, accompanied or not by proofs, under the conditions established in regulations.

13. An invention is endowed with inventive step provided that, to a technician versed in the subject, it is not derived in an evident or obvious way from the state of the art.

14. A utility model is endowed with inventive act provided that, to a technician versed in the subject, it is not derived in a common or ordinary way from the state of the art.

15. An invention and a utility model are not considered susceptible of industrial application when they can be used or produced in any kind of industry. 


\section{Section II \\ Priority}

16. A patent application filed in a country that maintains an agreement with Brazil, or in an international organization, and that produces the effect of a national filing, shall be assured the right of priority, within the time limits established in the agreement, and the filing shall not be invalidated or prejudiced by events occurring within such time limits.

(1) The claim of priority shall be made at the time of filing, and may be supplemented within 60 (sixty) days by other priorities prior to the filing date in Brazil.

(2) The claim of priority shall be proven by a proper document from the country of origin, containing the number, date, title, specifications and, if applicable, claims and drawings, accompanied by a free translation of the filing certificate or equivalent document, containing identifying information on the application, for which content the applicant is solely responsible.

(3) If not submitted at the time of filing, the proofs must be submitted within up 180 (one hundred and eighty) days of the date of filing.

(4) For international applications filed under a treaty in force in Brazil, the translation referred to in Paragraph 2 must be submitted within a period of 60 (sixty) days of the date of entry into national processing.

(5) If an application filed in Brazil is faithfully reproduced in the document from the country of origin, a statement by the applicant about that shall be sufficient to replace the free translation.

(6) When priority is obtained by assignment, the corresponding document must be submitted within 180 (one hundred and eighty) days of the filing date or, if applicable, within up 60 (sixty) days of the date of entry into national processing, and consular legalization in the country of origin shall not berequired.

(7) Failure to provide proof within the time limits provided for in this Article shall result in the loss of priority.

(8) In the case of an application filed along with a claim of priority, the application for early publication must be accompanied of the proof of priority.

17. An application for an invention or utility model patent originally filed in Brazil, without claiming priority and not yet published, shall assure the right of priority for the subsequent application on the same subject matter filed in Brazil by the same applicant or by successors, within a period of 1 (one) year.

(1) The priority shall be admitted only for the subject matter disclosed in the earlier application, and does not extend to any new subject matter that is introduced.

(2) An earlier application that is still pending shall be considered as definitively dismissed. 
(3) A patent application originating from the division of an earlier application may not serve as the basis for claiming priority.

\section{Section III \\ Non-Patentablef Inventions and Utility Models}

18. The following are not patentable:

I - anything contrary to morals, standards of respectability and public security, order and health;

II - substances, materials, mixtures, elements or products of any kind, as well as the modification of their physical-chemical properties and the respective processes for obtainment or modification, when resulting from the transformation of the atomic nucleus; and

III - all or part of living beings, except transgenic microorganisms that satisfy the three requirements of patentability-novelty, inventive step and industrial application-provided for in Article 8 and which are not mere discoveries.

Sole Paragraph. For the purposes of this Law, transgenic microorganisms are organisms, except for all or part of plants or animals, that express, by means of direct human intervention in their genetic composition, a characteristic normally not attainable by the species under natural conditions.

\section{CHAPTER III \\ PATENT APPLICATIONS}

\section{Section I \\ Filing of Application}

19. A patent application, in accordance with the conditions established by the INPI, shall contain:

I - the application;

II - the specifications;

III - the claims;

IV - drawings, if applicable;

$\mathrm{V}$ - the abstract; and

VI - proof of payment of the filing fee.

20. Once the application has been submitted, it shall undergo a formal preliminary examination and, if found to be properly documented, shall be docketed, the date of submission shall be considered as the date of filing.

21. An application that does not formally satisfy the provisions of Article 19, but that contains data relating to the object, to the applicant and to the inventor, may be submitted, 
against dated receipt, to the INPI, which shall stipulate the requirements to be satisfied, within a period of 30 (thirty) days, under penalty of having the documentation returned or the application dismissed.

Sole Paragraph. Upon satisfaction of the requirements, the filing shall be considered as having occurred on the date of the receipt.

\section{Section II \\ Conditions of the Application}

22. An invention patent application must refer to a single invention or group of inventions interrelated in such a way as to comprise a single inventive concept.

23. A utility model patent application must refer to a single principal model, which may include a plurality of distinct additional elements or constructive or configurative variants, provided that the technical-functional and corporeal unity of the object is maintained.

24. The specifications shall clearly and sufficiently describe the object, so as to permit its reproduction by a technician versed in the subject, and shall indicate, when applicable, the best way of doing it. Sole Paragraph. In the case of biological material that is essential to the practical execution of the object of the application, which cannot be described in accordance with this Article and which is not accessible to the public, the specifications shall be supplemented by the deposit of the material with an institution authorized by the INPI or indicated in an international agreement.

25. The claims shall be substantiated in the specifications, characterizing the particulars of the application, and clearly and precisely defining the subject matter that is the object of the protection.

26. A patent application may be divided into two or more applications, ex officio or at the application of the applicant, up to the end of the examination, provided that the divided application:

I - makes specific reference to the original application; and

II - does not exceed the subject matter disclosed in the original application.

Sole Paragraph. The application for division not in accordance with the provisions of this Article shall be dismissed.

27. The divided applications shall bear the filing date of the original application and have the benefit of priority thereof, if applicable.

28. Each divided application shall be subject to payment of the corresponding fees.

29. A patent application that has been withdrawn or abandoned must be published. 
(1) The application for withdrawal shall be submitted within up 16 (sixteen) months of the date of filing or of the oldest priority.

(2) The withdrawal of an earlier filing that has not produced any effect shall confer priority on the immediately subsequent filing.

\section{Section III}

\section{Processing and Examination of the Application}

30. A patent application shall be kept secret for 18 (eighteen) months from the date of filing or of the oldest priority, if any, after which it shall be published, except as provided for in Article 75.

(1) The publication of the application may be anticipated at the application of the applicant.

(2) The publication shall contain data identifying the patent application, and a copy of the specifications, claims, abstract and drawings shall remain available to the public at the INPI.

(3) In the case referred to in the Sole Paragraph of Article 24, the biological material shall become available to the public upon the publication referred to in this Article.

31. After publication of the application and up to the end of the examination, interested parties may submit documents and data to assist the examination. Sole Paragraph. The examination shall not begin before 60 (sixty) days from the publication of the application.

32. In order to better clarify or define a patent application, the applicant may make changes until the time of the application for examination, provided these are limited to the subject matter initially disclosed in the application.

33. The examination of a patent application must be applicationed by the applicant or by some other interested party, within a period of 36 (thirty six) months of the date of filing, under penalty of having the application dismissed. Sole Paragraph. A patent application may be reinstated, if the applicant so applications, within 60 (sixty) days of the date it was dismissed, upon payment of a specific fee, under penalty of having the application definitively dismissed.

34. After the examination has been applicationed, the following must be submitted, within a period of 60 (sixty) days, whenever applicationed, under penalty of having the application dismissed:

I - objections, search for prior art and results of examination for granting of a corresponding application in other countries, when priority is claimed;

II - documents necessary to regularize the processing and examination of the application; and 
III - free translation of the proper document referred to in Paragraph 2 of Article 16, if it was replaced by the statement referred to in Paragraph 5 of the same Article.

35. At the time of the technical examination, a report of search and an opinion shall be prepared with respect to:

I - patentability of the application;

II - appropriateness of the application given the nature claimed;

III - reformulation or division of the application; or

IV - technical requirements.

36. When the opinion ascertains the non-patentability of the application or the incompatibility of the application to the nature claimed, or makes some demand, the applicant shall be notified to submit comments within a period of 90 (ninety) days.

(1) If there is no response to the demand, the application shall be definitively dismissed.

(2) If there is response to the demand, even if it has not been satisfied, or its formulation is contested, and whether or not comments on patentability or compatibility have been submitted, the examination shall be continued.

37. Once the examination has been concluded, a decision shall be handed down, either approving or rejecting the patent application.

\section{CHAPTER IV \\ GRANTING AND TERM OF THE PATENT}

\section{Section I \\ Granting of the Patent}

38. A patent shall be granted after the application is approved, and proof of payment of the corresponding fee has been furnished, by means of issuing the respective patent certificate.

(1) The payment of the fee and its respective proof of payment must be done within a period of 60 (sixty) days of approval.

(2) The fee provided for in this Article may also be paid and proven within 30 (thirty) days of the time limit referred to in the preceding Paragraph, independently of any notification, upon payment of a specific fee, under penalty of having the application definitively dismissed.

(3) A patent shall be deemed to have been granted on the date of publication of the respective act.

39. The patent certificate shall contain its number, title and nature, the name of the inventor, with due regard for the provisions of Paragraph 4 of Article 6, the identification 
and domicile of the titleholder, the term, the specifications, the claims, and the drawings, as well as the data regarding priority.

\section{Section II \\ Term of the Patent}

40. An invention patent shall remain in force for a period of 20 (twenty) years, and a utility model patent for a period of 15 (fifteen) years from the date of filing. Sole Paragraph. The term shall not be less than 10 (ten) years for an invention patent and 7 (seven) years for a utility model patent, beginning on the date of granting, unless the INPI has been prevented from examining the merits of the application by a proven pending judicial dispute or for reasons of force majeure.

\section{CHAPTER V \\ PROTECTION CONFERRED BY THE PATENT}

\section{Section I \\ Rights}

41. The scope of the protection conferred by the patent shall be determined by the content of the claims, and interpreted on the basis of the specifications and drawings.

42. A patent confers on its titleholder the right to prevent a third party from, without his consent, producing, using, offering for sale, selling or importing for these purposes: I - a product that is the object of the patent;

II - a process or a product directly obtained by a patented process.

(1) The patentholder is further assured the right to prevent third parties from contributing to the perpetration by others of the acts referred to in this Article.

(2) A process patent right, referred to in Item II, shall be deemed to have occurred when the possessor or owner does not prove, by a specific judicial ruling, that his product was obtained by a manufacturing process different than the one protected by the patent.

43. The provisions of the previous Article do not apply:

I - to acts carried out by unauthorized third parties, privately and without commercial purposes, provided these acts do not prejudice the economic interests of the patentholder; II - to acts carried out by unauthorized third parties for experimental purposes, in connection with scientific or technological studies or researches;

III - to the preparation of a medicine in accordance with a medical prescription for individual cases, carried out by a qualified professional, as well as to the medicine so prepared;

IV - to a product manufactured in accordance with a process or product patent that has been introduced onto the domestic market directly by the patentholder or with his consent; 
$\mathrm{V}$ - to third parties who, in the case of patents related to living material, use the patented product, without economic intent, as an initial source of variation or propagation to obtain other products; and VI - to third parties who, in case of patents related to living material, use, place in circulation, or market a patented product that has been legally introduced into commerce by the patentholder or the holder of a license, provided that the patented product is not used for commercial multiplication or propagation of the living material in question.

44. The patentholder is assured the right to obtain indemnification for improper exploitation of the object of his patent, including that which occurs between the date of publication of the application and the date of granting of the patent.

(1) If the transgressor obtained, by any means, knowledge of the content of the filed application prior to the publication, the period of improper exploitation, for purposes of indemnification, shall be calculated beginning with the date of the start of the exploitation.

(2) When the object of the patent application refers to biological material, deposited as provided in the Sole Paragraph of Article 24, the right to indemnification shall be recognized only when the biological material has become available to the public.

(3) The right to obtain indemnification for improper exploitation, including that related to the period prior to the granting of the patent, is restricted to the content of its object, as provided for in Article 41.

\section{Section II \\ Prior User}

45. A person who in good faith, prior to the filing or priority date of a patent application, was exploiting the object thereof in this country, shall be assured the right to continue the exploitation, without onus, in the same manner and under the same conditions as before. (1) The right conferred under this Article may only be assigned together with the business or company, or part thereof that is directly related to the exploitation of the object of the patent, by transfer or leasing.

(2) The right referred to in this Article shall not be assured to a person who gained knowledge of the object of the patent through disclosure, in accordance with Article 12, provided that the application has been filed within 1 (one) year of the disclosure. 


\section{CHAPTER VI \\ NULLITY OF A PATENT}

\section{Section 1 \\ General Provisions}

46. A patent granted contrary to the provisions of this Law is null.

47. Nullity may not apply to all the claims, and the condition of partial nullity is the fact that the subsisting claims in themselves constitute patentable subject matter.

48. Nullity of a patent shall produce effects from the filing date of the application.

49. In the case of non-compliance with the provisions of Article 6, the inventor may, alternatively, demand, in judicial proceedings, adjudication of the patent.

\section{Section II \\ Administrative Nullity Proceedings}

50. Nullity of a patent shall be administratively declared when:

I - any of the legal requirements were not satisfied;

II - the specifications and claims did not comply with the provisions of Articles 24 and 25 , respectively;

III - the object of the patent extends beyond the contents of the application filed originally; or

IV - any of the essential formalities that are indispensable to granting has been omitted during the processing thereof.

51. Nullity proceedings may be instituted either ex officio or at the application of any person having a legitimate interest, within a period of 6 (six) months of the granting of the patent. Sole Paragraph. Nullity proceedings shall continue even if the patent has been extinguished.

52. The titleholder shall be notified to submit comments within a period of 60 (sixty) days.

53. After the time limit established in the preceding Article has elapsed, whether or not comments were submitted, the INPI shall issue an opinion and notify the titleholder and the applicant to submit their comments within the common period of 60 (sixty) days.

54. After the time limit established in the preceding Article has elapsed, even if no comments have been submitted, the case shall be decided by the President of the INPI, whereupon the administrative jurisdiction shall be ended.

55. The provisions of this Section apply, where applicable, to certificates of addition. 


\section{Section III \\ Judicial Nullity Proceedings}

56. Judicial nullity proceedings may be proposed, at any time during the term of the patent, either by the INPI or by any person having a legitimate interest.

(1) Nullity of a patent may be argued at any time as a matter of defense.

(2) The judge may, as a preventive or incidental measure, order the suspension of the effects of the patent, provided that the proper procedural requirements have been satisfied.

57. Patent judicial nullity proceedings shall be filed within the Federal Court forum, and the INPI, when not the plaintiff, shall participate in them.

(1) The time limit for a response by the defendant who is the patentholder shall be 60 (sixty) days.

(2) Once the decision on the judicial nullity proceedings has become final, the INPI shall publish the entry thereof, so that third parties be informed.

\section{CHAPTER VII \\ ASSIGNMENT AND ENTRIES}

58. A patent application or a patent, the contents of both being indivisible, may be assigned in whole or in part.

59. The INPI shall make the following entries:

I - assignment, stating full identification of the assignee;

II - any limitation or onus that applies to the application or the patent; and

III - changes in the name, headquarter, or address of the applicant or the titleholder.

60. Entries shall become effective with regard to third parties beginning on the date of their publication.

\section{CHAPTER VIII}

LICENSES

\section{Section I \\ Voluntary Licenses}

61. The patentholder or the applicant may enter into a licensing contract for exploitation. Sole Paragraph. The licensee may be invested by the titleholder with full powers to take action to defend the patent.

62. The license contract must be recorded with the INPI so that it becomes effective regarding third parties.

(1) The recording shall become effective with regard to third parties beginning on the date of its publication. 
(2) For the purposes of validating proof of use, the license contract shall not need to be recorded with the INPI.

63. An improvement introduced in a licensed patent shall belong to the party that makes the improvement, and the other party is entitled to a preferential right to the licensing thereof.

\section{Section II \\ Offer of License}

64. The patentholder may ask the INPI to offer it with a view to its exploitation.

(1) The INPI shall arrange for publication of the offer.

(2) No voluntary license contract of an exclusive nature shall be recorded with the INPI unless the titleholder has desisted from the offer.

(3) A patent that is under voluntary license on an exclusive basis may not be the object of an offer.

(4) The titleholder may, at any time prior to the express acceptance of his terms by the interested party, withdraw the offer, and the provisions of Article 66 shall not apply.

65. In the absence of an agreement between the titleholder and the licensee, the parties may ask the INPI to arbitrate the remuneration.

(1) For the purposes of this Article, the INPI shall observe the provisions of Paragraph 4 of the Article 73.

(2) The remuneration may be revised after 1 (one) year has elapsed since it was established.

66. The patent subject to offer shall have the annual fee reduced to one-half during the period between the offer and the granting, by whatever means, of the first license.

67. The patentholder may application cancellation of a license if the licensee does not begin effective exploitation within 1 (one) year of the date of granting, if exploitation is interrupted for a period of more than 1 (one) year, or if the conditions for exploitation have not been satisfied.

\section{Section III Compulsory License}

68. The titleholder shall be subject to having the patent licensed on a compulsory basis if he exercises his rights derived therefrom in an abusive manner, or by means thereof engages in abuse of economic power, proven pursuant to law in an administrative or judicial decision.

(1) The following also occasion a compulsory license: 
I - non-exploitation of the object of the patent within the Brazilian territory for failure to manufacture or incomplete manufacture of the product, or also failure to make full use of the patented process, except cases where this is not economically feasible, when importation shall be permitted; or II - commercialization that does not satisfy the needs of the market.

(2) A license may be applicationed only by a person having a legitimate interest and having technical and economic capacity to effectively exploit the object of the patent, that shall be destined predominantly for the domestic market, in which case the exception contained in Item I of the previous Paragraph shall be extinguished.

(3) In the case that a compulsory license is granted on the grounds of abuse of economic power, the licensee who proposes local manufacture shall be assured a period, limited to the provisions of Article 74, to import the object of the license, provided that it was introduced onto the market directly by the titleholder or with his consent.

(4) In the case of importation to exploit a patent and in the case of importation as provided for in the preceding Paragraph, third parties shall also be allowed to import a product manufactured according to a process or product patent, provided that it has been introduced onto the market by the titleholder or with his consent.

(5) The compulsory license that is the subject of Paragraph 1 shall only be required when 3 (three) years have elapsed since the patent was granted.

69. A compulsory license shall not be granted if, on the date of the application, the titleholder:

I - justifies the non-use based on legitimate reasons;

II - proves that serious and effective preparations for exploitation have been made;

III - justifies the failure to manufacture or to market on grounds of an obstacle of legal nature;

70. The compulsory license shall also be granted when all the following circumstances apply:

I - there is a situation of dependency of one patent with regard to another;

II - the object of the dependent patent constitutes a substantial technical progress with regard to the earlier patent; and

III - the titleholder fails to reach agreement with the patentholder of the dependent patent on the exploitation of the earlier patent.

(1) For the purposes of this Article, a dependent patent is considered to be a patent whose exploitation necessarily depends on the use of the object of an earlier patent.

(2) For purposes of this Article, a process patent may be considered dependent on the respective product patent, and likewise, a product patent may be dependent on a process patent. 
(3) The patentholder licensed pursuant to the provisions of this Article shall have the right to a crossed compulsory license on the dependent patent.

71. In cases of national emergency or of public interest, as declared in an act of the Federal Executive Power, and provided the patentholder or his licensee does not fulfill such need, a temporary and non-exclusive compulsory license for exploiting the patent may be granted, ex officio, without prejudice to the rights of the respective titleholder. Sole Paragraph. The act of granting the license shall establish its term and the possibility of extension.

72. Compulsory licenses shall always be granted on a non-exclusive basis, and sublicensing shall not be permitted.

73. The application for a compulsory license shall be formulated upon indication of the conditions offered to the patentholder.

(1) After an application for a license has been submitted, the titleholder shall be notified to submit comments within a period of 60 (sixty) days, at the end of which, if the titleholder has not submitted comments, the proposal shall be deemed to have been accepted under the conditions offered.

(2) An applicant for a license who alleges abuse of patent rights or abuse of economic power must attach documentation that proves it.

(3) In the case that the compulsory license is applied for on grounds of failure to exploit, the patentholder shall prove the exploitation.

(4) If the application is contested, the INPI may conduct the necessary inquires, including the establishment of a committee, which may include specialists who are not on the staff of that autarky, to arbitrate the remuneration to be paid to the titleholder.

(5) The agencies and entities of direct or indirect, federal, state, and municipal public administration shall furnish the INPI with information as applicationed for purposes of assisting in the arbitration of the remuneration.

(6) In the arbitration of the remuneration, the circumstances of each case shall be considered, and it shall consider, necessarily, the economic value of the license granted.

(7) After evidence has been gathered in the case, the INPI shall decide about the granting and the conditions of the compulsory license within a period of 60 (sixty) days. (8) The appeal of the decision that granted a compulsory license shall not have suspensive effect.

74. Unless in case of legitimate reasons, the licensee must begin the exploitation of the object of the patent within a period of 1 (one) year from the granting of the license, and an interruption for a same period of time shall be allowed.

(1) The titleholder may require the cancellation of the license when the provision of this Article is not observed.

(2) The licensee shall be invested with full powers to take action to defend the patent. 
(3) After a compulsory license has been granted, the assignment of such license shall only be allowed together with the assignment, transfer or leasing of the part of the enterprise that exploits it.

\section{CHAPTER IX \\ PATENT OF INTEREST TO NATIONAL DEFENSE}

75. A patent application originating in Brazil and whose object is of national defense interest shall be processed as confidential and shall not be subject to the publications established in this Law.

(1) The INPI shall forward the application immediately to the competent agency of the Executive Power, which shall make a statement on its confidentiality within a period of 60 (sixty) days. If this period elapses without any statement of the competent agency, the application shall be normally processed.

(2) The filing in another country of a patent whose object has been deemed of national defense interest is prohibited, as is any disclosure thereof, unless express authorization from the competent agency.

(3) The exploitation and the assignment of the application or patent that is of national defense interest are conditioned upon prior authorization from the competent agency, and indemnification is assured whenever the rights of the applicant or titleholder are restricted.

\section{CHAPTER $X$ CERTIFICATE OF ADDITION OF INVENTION}

76. The applicant or the titleholder of an invention patent may require, upon payment of a specific fee, a certificate of addition in order to protect an improvement or development that has been introduced into the object of the invention, even if devoid of inventive step, provided the subject matter is included in the same inventive concept.

(1) When the principal application has already been published, the application for a certificate of addition shall be published immediately.

(2) The examination of an application for a certificate of addition shall comply with the provisions of Articles 30 through 37, except as provided in the preceding Paragraph. (3) The application for a certificate of addition shall be denied if its object does not exhibit the same inventive concept.

(4) The applicant may, within the period provided for an appeal and by paying the applicable fees, require the conversion of the application for a certificate of addition into a patent application, thereby benefiting from the filing date of the application for a certificate. 
77. The certificate of addition is an accessory of the patent, bears the final date of the term thereof, and accompanies it for all legal effects.

Sole Paragraph. In nullity proceedings, the titleholder may require that the subject matter of the certificate of addition be analyzed in order to determine the possibility of its subsistence, without prejudice of the term of the patent.

\section{CHAPTER XI \\ EXTINGUISHMENT OF A PATENT}

78. A patent is extinguished:

I - on expiration of the term;

II - on renunciation by its titleholder, without prejudice to the rights of other parties;

III - on forfeiture;

IV - on failure to pay the annual fee, within the time limits stipulated in Paragraph 2 of Article 84, and in Article 87; and

$\mathrm{V}$ - on non-compliance with the provisions of Article 217.

Sole Paragraph. Once the patent has been extinguished, its object falls into the public domain.

79. The renunciation shall only be accepted if it does not prejudice the rights of third parties.

80. The patent shall be forfeited, ex officio or at the application by any party having a legitimate interest, if, after 2 (two) years have elapsed since the granting of the first compulsory license, that time period has not been sufficient to prevent or remedy the abuse or disuse, unless there are justifiable reasons.

(1) The patent shall be forfeited when, on the date of the application for forfeiture or ex officio institution of the respective proceedings, exploitation has not yet begun.

(2) In forfeiture proceedings instituted upon application, the INPI may proceed if the applicant waives it.

81. The titleholder shall be notified upon publication to submit comments, within a period of 60 (sixty) days, and the burden of proof as regards exploitation shall lie with him.

82. The decision shall be issued within 60 (sixty) days from the end of the period mentioned in the preceding Article.

83. The decision on forfeiture shall produce effects from the date of the application or of the publication of the ex officio institution of proceedings. 


\section{CHAPTER XII}

ANNUAL FEE

84. The applicant and the patent holder are subject to payment of annual fee since the beginning of the third year after the filing date.

(1) Anticipated payment of the annual fee shall be regulated by the INPI.

(2) Payment shall be made within the first 3 (three) months of each annual period, but it may also be made within the following 6 (six) months, independently from any notification, upon payment of an additional fee.

85. The provisions of the previous Article apply to international applications filed under a treaty in force in Brazil, and the payment of the annual fees that fell due prior to the date of entry into the national processing shall be made within a period of 3 (three) months of that date.

86. The failure to pay the annual fee, in accordance with provisions of Articles 84 and 85 , shall result in the dismissal of the application or extinguishment of the patent.

\section{CHAPTER XIII RESTORATION}

87. The patent application or the patent may be restored, if the applicant or titleholder so applications, within 3 (three) months from the notification of the dismissal of the application or the extinguishment of the patent, upon payment of a specific fee.

\section{CHAPTER XIV \\ INVENTIONS AND UTILITY MODELS CREATED BY EMPLOYEES OR SERVICE PROVIDERS}

88. The invention and the utility model belong exclusively to the employer when they result from an employment contract being performed in Brazil and that has research or the inventive step as its object, or if such results from the nature of the services for which the employee was hired.

(1) Except as otherwise stipulated by contract, the retribution for the work to which this Article refers is limited to the agreed salary.

(2) In the absence of proof to the contrary, the invention or utility model on which a patent is applied for by the employee, up to 1 (one) year of the extinguishment of the employment relationship, is considered to have been developed during the term of the contract.

89. The employer, the patent holder, may grant the employee, the author of the invention or improvement, a share in the economic gains resulting from the exploitation of the patent, by negotiating with the interested party or in accordance with the rules of the 
company.Sole Paragraph. The share referred to in this Article does not incorporate, in any way, into the salary of the employee.

90. The invention or the utility model developed by an employee shall belong exclusively to him, provided that it is unrelated to the employment contract and does not result from the use of resources, means, data, materials, facilities or equipment of the employer.

91. The property of an invention or utility model shall be common, in equal parts, when it results from the personal contribution of the employee and resources, data, means, materials, facilities or equipment of the employer, in the absence of express contract provision to the contrary.

(1) When there is more than one employee, the portion that corresponds to them shall be divided equally among all of them, except as agreed to the contrary.

(2) The employer is guaranteed the exclusive right of license for exploitation, and the employee is assured the fair remuneration.

(3) In the absence of an agreement, the exploitation of the object of the patent must be started by the employer within a period of 1 (one) year of the date of granting, under penalty of the property of the patent being transferred as an exclusive right to the employee, except where there are legitimate reasons for the failure to exploit.

(4) In the event of an assignment, any of the co-titleholders, under the same conditions, may exercise the right of preference.

92. The provisions of the preceding Articles apply, where applicable, to relationships between an autonomous worker or a trainee and the contracting company, and between contracting and contracted companies.

93. The provisions of this Chapter apply, where applicable, to the direct, indirect and foundational, federal, state or municipal entities of the Public Administration.

Sole Paragraph. In the event that is the subject of Article 88, the inventor shall be assured, in the manner and under the conditions set forth in the statutes or internal regulations of the entity to which this Article refers, an award of part of the value of the benefits gained from the application or patent, as an incentive.

TITLE II

INDUSTRIAL DESIGNS

\section{CHAPTER I \\ OWNERSHIP}

94. The author shall be assured the right to obtain registration of an industrial design that confers property on him, under conditions established in this Law. 
Sole Paragraph. The provisions of Articles 6 and 7 apply to the registration of industrial designs, where applicable.

\section{CHAPTER II \\ REGISTRABILITY \\ Section I \\ Registrable Industrial Designs}

95. An industrial design is considered to be an ornamental plastic form of an object or an ornamental arrangement of lines and colors which may be applied to a product, providing a new and original visual result in its external configuration and that may serve as a model for industrial manufacture.

96. The industrial design is considered as new when it is not comprised in the state of the art.

(1) The state of the art consists of everything made available to the public prior to the filing date of the application, in Brazil or abroad, by use or by any other means, without prejudice to the provisions of Paragraph 3 of this Article and of Article 99.

(2) For the sole purpose of determining novelty, the entire content of an application for a patent or for registration filed in Brazil, and not yet published, shall be considered to be included in the state of the art as from the date of filing, or of claimed priority, provided it comes to be published, even if subsequently.

(3) The industrial design shall not be considered to be included in the state of the art if disclosure occurred during the 180 (one hundred and eighty) days preceding the filing date of the application or of the claimed priority, if made in the situations outlined in Items I to III of Article 12.

97. The industrial design is considered to be original when it results in a distinctive visual configuration, in relation to other prior objects.

Sole Paragraph. The original visual result may be derived from the combination of known elements.

98. No purely artistic work is considered to be an industrial design.

\section{Section II \\ Priority}

99. The provisions of Article 16, except for the time limit defined in Paragraph 3 of that Article, which shall be of 90 (ninety) days, apply to the application for registration, where applicable. 


\section{Section III \\ Non-Registrable Industrial Designs}

100. It is not registrable as an industrial design:

I - anything contrary to morals and standards of respectability or that offends the honor or image of persons, or attempts freedom of conscience, belief, religious cult or ideas and feelings worthy of respect and veneration;

II - the common or ordinary necessary shape of the object or, yet, that shape which is essentially determined by technical or functional considerations.

\section{CHAPTER III \\ APPLICATIONS FOR REGISTRATION}

\section{Section I \\ Filing of Applications}

101. An application for registration, under the conditions stipulated by the INPI, shall contain:

I - the application;

II - the specifications, if applicable;

III - the claims, if applicable;

IV - drawings or photographs;

$\mathrm{V}$ - field of application of the object; and

VI - proof of payment of the filing fee.

Sole Paragraph. The documents that comprise the application for registration shall be submitted in Portuguese language.

102. Once the application have been submitted, it shall be subjected to a preliminary formal examination and, if found to be properly documented, shall be docketed, considered the filing date to be the date of submission.

103. The application that does not formally attend the provisions of Article 101, but which contains sufficient data related to the applicant, to the industrial design and to the author, may be submitted, against dated receipt, to the INPI, that shall establish the requirements to be satisfied, within 5 (five) days, under penalty of being considered non-existent.

Sole Paragraph. Once the requirements have been satisfied, the filing shall be considered as made on the date the application was submitted. 


\section{Section II \\ Conditions of Applications}

104. The application for industrial design registration shall refer to a single object, of which a plurality of variations shall be permitted, provided that they are intended for the same purpose and all retain the same preponderant distinctive characteristic, each application limited to a maximum of 20 (twenty) variations.

Sole Paragraph. The design shall clearly and sufficiently represent the object and its variations, if any, in such a manner as to permit its reproduction by a technician versed in the subject.

105. If secrecy is applicationed pursuant to Paragraph 1 of Article 106, the application may be withdrawn within up 90 (ninety) days from the date of the filing.

Sole Paragraph. The withdrawal of an earlier filing without the production of any effects shall confer priority on the immediately subsequent filing.

\section{Section III}

\section{Processing and Examination of the Applications}

106. Once the application for an industrial design registration has been filed and the provisions of Articles 100, 101 and 104 have been observed, it shall automatically be published and the registration shall be granted simultaneously, being issued the respective certificate.

(1) At the application of the applicant, made at the time of the filing, an application may be kept secret for a period of 180 (one hundred and eighty) days from the filing date, after which it shall be processed.

(2) If the applicant benefits from the provisions of Article 99, the submission of the priority document for processing the application is to be waited.

(3) If the provisions of Articles 101 and 104 are not satisfied, a demand shall be drawn up and the applicant shall reply it within 60 (sixty) days, under penalty of having the application definitively dismissed.

(4) If the provisions of Article 100 are not satisfied, the application for registration shall be denied.

\section{CHAPTER IV \\ GRANT AND TERM OF THE REGISTRATION}

107. The certificate shall contain the number and the title, name of the author-with due regard for provisions of Paragraph 4 of Article 6, the name, the nationality and the domicile of the titleholder, the term, the drawings, the data related to foreign priority, and, if any, the specifications and claims. 
108. The registration shall remain in force for a period of 10 (ten) years from the date of filing, being extendable for 3 (three) successive periods of 5 (five) years each.

(1) The application for extension shall be made during the last year of the term of the registration, accompanied by proof of payment of the respective fee.

(2) If the application for extension has not been formulated until the final term of registration, the titleholder may do so within the following 180 (one hundred and eighty) days, against payment of an additional fee.

\section{CHAPTER V \\ PROTECTION CONFERRED BY THE REGISTRATION}

109. The property of an industrial design is acquired by a validly granted registration. Sole Paragraph. The provisions of Article 42 and Items I, II and IV of Article 43 apply to an industrial design registration, where applicable.

110. A person who, in good faith, prior to the filing date or priority date of an application for registration was exploiting the object thereof in this country, shall be assured the right to continue the exploitation, without onus, in the same manner and under the same conditions as before.

(1) The right conferred under this Article may only be assigned together with the business or company, or part of thereof, that is directly related to the exploitation of the object of the registration, by transfer or leasing.

(2) The right that is subject of this Article shall not be assured to a person who gained knowledge of the object of the registration through disclosure under Paragraph 3 of Article 96, provided that the application was filed within a period of 6 (six) months from disclosure.

\section{CHAPTER VI \\ EXAMINATION OF THEMERITS}

111. The titleholder of an industrial design may application the examination of the object of registration, at any time during the term of the registration, in relation to novelty and originality aspects.

Sole Paragraph. The INPI shall issue an opinion on the merits which, if it concludes that at least one of the requirements defined in Articles 95 to 98 is absent, shall serve as grounds for ex officio institution of procedure for nullity of the registration. 


\section{CHAPTER VII \\ NULLITY OF REGISTRATION}

\section{Section I \\ General Provisions}

112. A registration granted contrary to the provisions of this Law is null.

(1) Nullity of the registration shall produce effects from the filing date of the application.

(2) In the event of non-compliance with the provisions of Article 94, the author may, alternatively, demand adjudication of the registration.

\section{Section II \\ Administrative Nullity Proceedings}

113. Nullity of a registration shall be administratively declared if it has been granted in violation to the provisions of Articles 94 to 98 .

(1) Nullity proceedings may be instituted ex officio or at the application of any person having a legitimate interest, within a period of 5 (five) years from the date of granting of the registration, without prejudice of the case referred to in the Sole Paragraph of Article 111.

(2) The application or the ex officio institution of proceedings shall suspend the effects of the granting of the registration if submitted or published within 60 (sixty) days from the grant.

114. The titleholder shall be notified to submit his comments within a period of 60 (sixty) days from the date of publication.

115. After the time limit established in the preceding Article has elapsed, whether or not comments were submitted, the INPI shall issue an opinion and notify the titleholder and the applicant to submit their comments within the common period of 60 (sixty) days.

116. After the time limit established in the preceding Article has elapsed, even if no comments have been submitted, the case shall be decided by the President of the INPI, whereupon the administrative jurisdiction shall be ended.

117. Nullity proceedings shall continue even if the registration has been extinguished.

\section{Section III Judicial Nullity Proceedings}

118. The provisions of Articles 56 and 57 shall apply to judicial nullity proceedings of an industrial design registration, where applicable. 


\section{CHAPTER VIII \\ EXTINGUISHMENT OF THE REGISTRATION}

119. A registration shall be extinguished:

I - on expiration of the term;

II - on renunciation by its titleholder, without prejudice to the rights of third parties;

III - on failure to pay the fee stipulated in Articles 108 and 120, or

IV - on non-compliance with the provisions of Article 217.

\section{CHAPTER IX}

\section{FIVE-YEAR FEE}

120. The titleholder of a registration is subject to payment of a five-year fee since the second five year period from the filing date.

(1) Payment of the second five-year period shall be made during the 5th (fifth) year of the term of the registration.

(2) Payment for all other five-year periods shall be made at the time of the application for extension referred to in Article 108.

(3) Payment of five-year fees may also be made within 6 (six) months following the period established in the preceding Paragraph, upon payment of an additional fee.

\section{CHAPTER $X$ \\ FINAL PROVISIONS}

121. Provisions of Articles 58 to 63 apply, where applicable, to the subject matter covered by this Title, and the rights of the employee or of the service provider are governed by the provisions of Articles 88 to 93.

\section{TITLE III \\ MARKS \\ CHAPTER I \\ REGISTRABILITY}

\section{Section I}

Signs Registrable as Marks

122. Any distinctive visually perceivable signs that are not included in legal prohibitions shall be eligible for registration as a mark.

123. For the purposes of this Law, the following definitions apply:

I - product or service mark: one which is used to distinguish a product or service from another that is identical, similar, or alike, but of different origin. 
II - certification mark: one that is used to attest to the conformity of a product or service with certain technical standards or specifications, particularly regarding its quality, nature, material used and methodology employed; and III - collective mark: one that is used to identify products or services provided by members of a certain entity.

\section{Section II \\ Signs Not Registrable as Marks}

124. The following are not registrable as marks:

I - official, public, national, foreign or international escutcheons, coats of arms, medals, flags, emblems, badges and monuments, as well as the respective designations, figures, or imitations;

II - letters, numerals and dates, standing alone, except when endowed with sufficiently distinctive form;

III - expressions, figures, drawings or any other signs that are contrary to morals and standards of respectability or that offend the honor or image of persons or attempt freedom of conscience, belief, religious cult or ideas and feelings worthy of respect and veneration;

IV - designations or initials of public entities or agencies, when registration is not required by the public entity or agency itself;

$\mathrm{V}$ - reproductions or imitations of a characteristic or differentiating element of a title of an establishment or a name of a company belonging to third parties, likely to cause confusion or association with such distinctive signs;

VI - signs of generic, necessary, common, ordinary or simply descriptive character, when related to the product or service to be distinguished, or those commonly employed to designate a characteristic of the product or service regarding its nature, nationality, weight, value, quality and time of production or rendering of the service, except when endowed with a sufficiently distinctive form;

VII - signs or expressions employed only as a means of advertising;

VIII - colors and their names, unless arranged or combined in a peculiar and distinctive manner;

IX - geographical indications, imitations thereof likely to cause confusion, or signs that may falsely induce a geographical indication;

$\mathrm{X}$ - signs that induce to a false indication regarding the origin, source, nature, quality or usefulness of the product or service to which the mark is applied;

$\mathrm{XI}$ - reproductions or imitations of an official seal normally used to guarantee a standard of any kind or nature;

XII - reproductions or imitations of a sign that has been registered as a collective or certification mark by a third party, with due regard to the provisions of Article 154; 
XIII - names, awards, or symbol of a sporting, artistic, cultural, social, political, economic or technical event that is official or officially sanctioned, as well as an imitation likely to create confusion, unless authorized by the competent authority or entity that is promoting the event.

XIV - reproductions or imitations of titles, policies, coins, and paper currency of the Union, the States, the Federal District, the Territories, the Municipalities, or of a country; $\mathrm{XV}$ - personal names or signatures thereof, family names and patronymics, or the image of third parties, except with the consent of the titleholder, his heirs or successors; XVI - well-known pseudonyms or nicknames, individual or collective artistic names, except with the consent of the titleholder, his heirs or successors;

XVII - literary, artistic or scientific work, as well as the titles protected by copyright and likely to cause confusion or association, except with the consent of the author or titleholder;

XVIII - technical terms used in industry, science and art, that are related to the product or service to be distinguished;

XIX - reproductions or imitations, in whole or in part, even with an addition, of a mark registered by another party, to distinguish or certify an identical, similar, or alike product or service, likely to cause confusion or association with the other party's mark; $\mathrm{XX}$ - duality of marks of a single titleholder for the same product or service, except when, in the case of marks of the same nature, they are endowed with a sufficiently distinctive form; XXI - the necessary, common, or ordinary form of the product or packing, or also that one which cannot be dissociated from a technical effect;

XXII - an object that is protected by a third party industrial design registration; and XXIII - signs that imitate or reproduce, wholly or in part, a mark of which the applicant could not be unaware because of his activity, and whose titleholder is headquartered or domiciled in national territory or in a country with which Brazil has an agreement or that assures reciprocity of treatment, if the mark is intended to distinguish an identical, similar or alike product or service likely to cause confusion or association with that other party's mark.

\section{Section III \\ Famous Marks}

125. A mark that is registered in Brazil and considered to be famous shall be assured special protection in all branches of activity. 


\section{Section IV \\ Well-Known Marks}

126. The well-known mark within its branch of activity pursuant to Article 6bis (I) of the Paris Convention for Protection of Industrial Property enjoys special protection, regardless of whether it has already been filed or registered in Brazil.

(1) The protection that is the subject of this Article also applies to service marks.

(2) The INPI may ex officio deny a application for registration of a mark that wholly or partially reproduces or imitates a well-know mark.

\section{CHAPTER II}

PRIORITY

127. The application for registration of a mark that has been filed in a country that maintains an agreement with Brazil or in an international organization, when such produces the effect of a national filing, shall be assured the right to priority, within the time limits established in the agreement, and the filing is neither invalidated nor prejudiced by events occurring within those time limits.

(1) The claim of priority shall be made at the time of filing and may be supplemented within 60 (sixty) days with other priorities prior to the date of filing in Brazil.

(2) The claim of priority shall be proved by a proper document from the country of origin containing the number, the date, and the copy of the application or registration, accompanied by a free translation, for whose content the applicant shall be solely responsible.

(3) If not done at the time of the filing, the substantiation must occur within up 4 (four) months of the filing, under penalty of forfeiture of the priority.

(4) In cases of priority obtained by transfer, the pertinent document must be submitted with the priority document itself.

\section{CHAPTER III \\ APPLICANTS FOR REGISTRATION}

128. Natural or legal persons under public or private law may apply for the registration of a mark.

(1) Persons under private law may only apply for registration of a mark that relates to the activity in with they actually and lawfully engage, either directly or through companies they directly or indirectly control, declaring that condition on the application itself, under the penalties of law.

(2) Registration of a collective mark may be applied for by a legal person that represents the collectivity, which may engage in an activity other than that pursued by its members. 
(3) Registration of a certification mark may only be applied for by a person who has no direct commercial or industrial interest in the product or service being certified.

(4) The claim of priority does not exempt the petition from the application of the provisions set forth in this Title.

\section{CHAPTER IV \\ RIGHTS OVER A MARK}

\section{Section I}

Acquisition

129. The property of a mark is acquired by means of registration, when validly granted pursuant to the provisions of this Law, and its exclusive use throughout the national territory is assured to the titleholder, with due regard, as to collective and certification marks, to the provision in Articles 147 and 148.

(1) Every person who, in good faith on the priority or filing date, has been using an identical or similar mark in this country for at least 6 (six) months to distinguish or certify an identical, similar or alike product or service shall have the right of preference for the registration.

(2) The right of preference may only be assigned together with the business of the company, or part thereof, that has a direct relation with the use of the mark, by transfer or leasing.

\section{Section II}

\section{Protection Conferred by the Registration}

130. The titleholder of a mark or the applicant is further assured the right to:

I - assign his registration or application for registration;

II - license its use;

III - safeguard its material integrity or reputation.

131. The protection that is the subject of this Law embraces the use of the mark on papers, printed matter, advertising, and documents related to the activities of the titleholder.

132. The titleholder of a mark may not:

I - prevent merchants or distributors from using their own distinctive signs along with the mark of the product, in its promotion and commercialization;

II - prevent manufacturers of accessories from using the mark to indicate the purpose of the product, provided that fair competition practices are followed;

III - prevent the free circulation of the product placed on the domestic market by himself or by another with his consent, except as provided in Paragraphs 3 and 4 of Article 68; and 
IV - prevent the mention of the mark in a speech, scientific or literary work, or in any other publication, provided it is done without commercial connotation and without detriment to its distinctive character.

\section{CHAPTER V \\ TERM, ASSIGNMENT AND ENTRIES}

\section{Section I \\ Term}

133. The registration of a mark shall remain in force for a period of 10 (ten) years from the date of granting of the registration, and the period may be extended for equal and successive periods.

(1) The application for extension shall be made during the last year of the term of the registration, accompanied by proof of payment of the respective fee.

(2) If the application for extension is not made before the term of the registration, the titleholder may do so during the following 6 (six) months, by payment of an additional fee.

(3) Extension will not be granted if the provision in Article 128 is not observed.

\section{Section II \\ Assignment}

134. The registration application and the registration may be assigned, provided the assignee satisfies the legal requirements for applying to register it.

135. The assignment must comprehend all the registrations or applications, in the name of the assignor, for the same or similar marks, related to an identical, similar, or alike product or service; under penalty of having the registrations cancelled or the unassigned applications dismissed.

\section{Section III}

\section{Entries}

136. The INPI shall make the following entries:

I - of the assignment, containing the full identification of the assignee;

II - of any limitation or onus that applies to the application or registration; and

III - of changes in the name, headquarter or address of the applicant or titleholder.

137. Entries shall become effective with regard to third parties beginning on the date of their publication.

138. The decisions may be appealed when:

I - it denies annotation of an assignment; 
II - it cancels the registration or dismisses the application, under the terms of Article 135.

\section{Section IV \\ License of Use}

139. The titleholder of a registration or the applicant for registration may enter into a license contract for use of the mark without prejudice to his rights to exercise effective control over the specifications, nature and quality of the respective products or services. Sole Paragraph. The licensee may be invested by the titleholder with full powers to take action to defend the mark, without prejudice to his own rights.

140. The license contract must be recorded with the INPI in order to become effective with regard to third parties.

(1) The recording shall become effective with regard to third parties from the date of its publication.

(2) For purposes of validating proof of use, it shall not be necessary that the license contract be recorded with the INPI.

141. A decision that denies the recording of a licensing contract may be appealed.

\section{CHAPTER VI LOSS OF RIGHTS}

142. The registration of the mark shall be extinguished:

I - on expiration of the term;

II - on renunciation, which may be full or partial regarding the products or services indicated by the mark;

III - on forfeiture; or

IV - on non-compliance with the provisions of Article 217.

143. A registration shall be forfeited upon application by a person having a legitimate interest if, after 5 (five) years have elapsed since granting, on the date of the application: I - the use of the mark has not been initiated in Brazil; or

II - the use of the mark has been interrupted for more than 5 (five) consecutive years, or if, in the same period of time, the mark has been used with a modification that entails alteration of its original distinctive character as appears on the registration certificate.

(1) Forfeiture will not occur if the titleholder justifies the failure to use the mark for legitimate reasons.

(2) The titleholder shall be notified to submit comments within a period of 60 (sixty) days, and the burden of proof, as regards use of the mark or justification of failure to use it for legitimate reasons, shall rest with him. 
144. The use of the mark must comprehend products or services listed on the certificate, under penalty of having the registration partially forfeited as regards products or services not similar or alike to those for which the mark is proven to have been used.

145. Applications for forfeiture shall not be considered if the use of the mark was proven or failure to use it was justified in a prior proceeding applicationed less than 5 (five) years previously.

146. A decision that declares or denies forfeiture may be appealed.

\section{CHAPTER VII COLLECTIVE AND CERTIFICATION MARKS}

147. The application for registration of a collective mark shall contain regulations on utilization, that provide conditions and prohibitions on the use of the mark.

Sole Paragraph. The regulations on utilization, when not accompanying the application, must be docketed within 60 (sixty) days from the filing date, under the penalty of having the application definitively dismissed.

148. The application of a registration of a certification mark shall contain:

I - the characteristics of the product or service that is the object of certification; and

II - the control measures that will be adopted by the titleholder.

Sole Paragraph. If the documentation referred to in Items I and II of this Article is not submitted with the application, it must be docketed within a period of 60 (sixty) days, under the penalty of having the application definitively dismissed.

149. The INPI must be notified of any change in the regulations on utilization, by means of docketed petition containing all the modified conditions, under penalty of not being considered.

150. The use of the mark does not require a license, being sufficient its authorization in the regulations on utilization.

151. In addition to the causes of extinguishment set forth in Article 142, the registration of a collective or certification mark is extinguished when:

I - the entity ceases to exist; or

II - the mark is used under conditions other than those stipulated in the regulations on utilization.

152. Renunciation of the registration of a collective mark shall only be permitted when applied for in accordance with the social contract or statutes of the entity itself, or in accordance with the regulations for utilization.

153. The forfeiture of the registration shall be declared if the collective mark is not used by more than one authorized person, with due regard for provisions of Articles 143 to 146. 
154. The collective and the certification marks that were once in use and whose registrations have been extinguished may not be registered in the name of a third party until 5 (five) years have elapsed since the extinguishment of the registration.

\section{CHAPTER VIII}

\section{FILING}

155. The application must refer to a single distinctive sign and shall, subject to the conditions stipulated by the INPI, contain the following:

I - the application;

II - labels, if applicable; and

III - proof of payment of the filing fee.

Sole Paragraph. The application and any documents accompanying it shall be submitted in the Portuguese language, and if any document is in foreign language, its free translation must be submitted at the time of filing or within the following sixty (60) days, under penalty of not having the document considered.

156. When the application has been submitted, it shall be subject to a preliminary formal examination, and if found to be properly documented, it shall be docketed, and the filing date of the application shall be considered as the date of submission.

157. Applications that do not formally comply with the provisions of Article 155, but which contains sufficient data related to the applicant, the mark sign and its class, may be delivered, against dated receipt, to the INPI, which shall stipulate the requirements to be satisfied by the applicant within 5 (five) days, under penalty of being deemed non-existent.

Sole Paragraph. Once the conditions have been satisfied, the filing shall be considered to have been made at the date the application was submitted.

\section{CHAPTER IX}

\section{EXAMINATION}

158. After being docketed, the application shall be published so that opposition may be presented within a period of 60 (sixty) days.

(1) The applicant shall be notified of the opposition and may submit comments within a period of 60 (sixty) days.

(2) The opposition, the administrative nullity proceedings, or the judicial nullity proceedings shall not be considered if, based on Item XXIII of Article 124, or on Article 126, the filing of the application for registration of the mark pursuant to this Law is not proven within a period of 60 (sixty) days from the interposition. 
159. After the period for opposition has elapsed or, if an opposition was presented, at the end of the period allowed for comments, the examination shall be done, and in its course demands may be formulated, and their responses must be submitted within a period of 60 (sixty) days.

(1) If an applicant does not respond to the demand, the application shall be definitively dismissed.

(2) If there is response to the demand, even if it has not been satisfied, or its formulation is contested, the examination shall be continued

160. When the examination has been concluded, a decision shall be handed down, either approving or rejecting the application for registration.

\section{CHAPTER $X$ \\ ISSUE OF REGISTRATION CERTIFICATE}

161. The registration certificate shall be issued after the application has been approved and proof of payment of the appropriate fees has been furnished.

162. Payment of the fees, and its proof, related to the issue of the registration certificate and to the first decade of its term, shall be done within a period of 60 (sixty) days of approval. Sole Paragraph. The fee may also be paid and proven within 30 (thirty) days of the time limit stipulated in this Article, independently of any notification, upon payment of a specific fee, under penalty of having the application definitively dismissed.

163. The registration certificate shall be deemed to have been granted on the date of publication of the respective act.

164. The certificate shall contain the mark, the number and date of registration, name, nationality and domicile of the titleholder, the products or services, the registration characteristics and the foreign priority.

\section{CHAPTER XI \\ NULLITY OF REGISTRATIONS}

\section{Section I \\ General Provisions}

165. A registration that is not granted in accordance with the provisions of this Law is null. Sole Paragraph. Nullity of the registration may be total or partial, and a condition for partial nullity shall be the fact that the subsisting part may be considered registrable.

166. The titleholder of a mark registered in a country that is a signatory of the Convention of the Union of Paris for the Protection of Industrial Property, may, alternatively, claim 
by means of judicial proceedings, the adjudication of the registration as set forth in Article 6septies (1) of that Convention.

167. The declaration of nullity shall produce effects beginning on the filing date.

\section{Section II \\ Administrative Nullity Proceedings}

168. Nullity of the registration shall be administratively declared when it has been granted in violation of the provisions of this Law.

169. Nullity proceedings may be instituted either exfofficiofor at the application of any person having a legitimate interest, within a period of 180 (one hundred and eighty) days of the date of the issue of the registration certificate.

170. The titleholder shall be formally notified to submit his comments within a period of 60 (sixty) days.

171. After the time limit established in the preceding Article has elapsed, even if no comments have been submitted, the case shall be decided by the President of the INPI, whereupon the administrative jurisdiction shall be ended.

172. Nullity proceedings shall continue even if the registration has been extinguished.

\section{Section III Judicial Nullity Proceedings}

173. Judicial nullity proceedings may be proposed either by the INPI or by any person having a legitimate interest. Sole Paragraph. The judge may, in the course of the judicial nullity proceedings, provisionally order suspension of the effects of registration and of the use of the mark, provided the proper procedural requirements have been satisfied.

174. Judicial proceedings to declare the nullity of a registration prescribe within 5 (five) years of the date of registration.

175. Judicial nullity proceedings of the registration shall be filed within the Federal Court system, and the INPI, when not the plaintiff, shall participate in them.

(1) The defendant titleholder shall have a period of sixty (60) days to reply.

(2) Once the decision on the judicial nullity proceedings has become final, the INPI shall punish the entry thereof, so that third parties may be informed.

TITLE IV

\section{GEOGRAPHICAL INDICATIONS}

176. A geographical indication shall be an indication of source or a denomination of origin. 
177. Indication of source shall mean the geographic name of a country, city, region or locality in its territory, which has become known as a center of extraction, production or manufacture of a given product or of provision of a given service.

178. Denomination of origin shall be the geographical name of a country, city, region or locality in its territory, that designates a product or service whose qualities or characteristics are due exclusively or essentially to the geographical environment, including natural and human factors.

179. The protection shall be extended to the graphical or figurative representation of a geographical indication, as well as the geographical representation of a country, city, region or locality in its territory whose name is a geographical indication.

180. Once a geographical name has fallen into the common use as designating a product or service, it shall not be considered to be a geographical indication.

181. A geographical name that does not constitute an indication of source or denomination of origin may serve as a characteristic element of a product or service mark, provided that it is not inducing to a false source.

182. The use of the geographical indication is restricted to those producers and service providers who are established in that locality, and it is also demanded, concerning denominations of origin, that the quality requirements be satisfied.

Sole Paragraph. The INPI shall establish the conditions for registration of geographical indications.

\section{TITLE V \\ CRIMES AGAINST INDUSTRIAL PROPERTY}

\section{CHAPTER I \\ CRIMES AGAINST PATENTS}

183. A crime against an invention or utility model patent is perpetrated by anyone who: I - manufactures a product that is the object of an invention or utility model patent, without authorization from the titleholder; or

II - uses a means or process that is the object of an invention patent, without authorization from the titleholder.

Penalty - imprisonment, from 3 (three) months to 1 (one) year, or a fine.

184. A crime against an invention or utility model patent is perpetrated by anyone who: I - exports, sells, displays or offers for sale, has in stock, conceals or receives, with a view to use for economic purposes, a product manufactured in violation of an invention or utility model patent, or obtained by a patented means or process; or 
II - imports a product that is the object of an invention or utility model patent, or obtained by a means or process patented in this country, for the purposes set forth in the preceding Item, and that has not been placed on the foreign market directly by the patentholder or with his consent.

Penalty - imprisonment, from 1 (one) to 3 (three) months, or a fine.

185. Supplying a component of a patented product, or material or equipment to execute a patented process, provided that the final application of the component, material or equipment leads necessarily to the exploitation of the object of the patent. Penaltyimprisonment, from 1 (one) to 3 (three) months, or a fine.

186. The crimes in this Chapter are determined to have been committed even when the violation does not affect all the claims of the patent or is restricted to the utilization of means equivalent to the object of the patent.

\section{CHAPTER II \\ CRIMES AGAINST INDUSTRIAL DESIGNS}

187. Manufacturing, without authorization from the titleholder, a product that incorporates a registered industrial design, or a substantial imitation that may induce to error or confusion.

Penalty-imprisonment, from 3 (three) months to 1 (one) year, or a fine.

188. A crime against industrial design registration is perpetrated by anyone who:

I - exports, sells, displays or offers for sale, has in stock, conceals or receives, with a view to use for economic purposes, an object that illegally incorporates a registered industrial design, or a substantial imitation that may induce to error or confusion; or

II - imports a product that incorporates an industrial design registered in this country, or a substantial imitation that may induce to error or confusion, for the purposes set forth in the preceding Item, and that has not been placed on the foreign market directly by the titleholder or with his consent.

Penalty - imprisonment, from 1 (one) to 3 (three) months, or a fine.

\section{CHAPTER III \\ CRIMES AGAINSTMARKS}

189. A crime against mark registration is perpetrated by anyone who:

I - reproduces a registered mark, in whole or in part, without the authorization from the titleholder, or imitates it in a way that may induce to confusion; or

II - alters the registered mark of another person already affixed on a product placed on the market.

Penalty - imprisonment, from 3 (three) months to 1 (one) year, or a fine. 
190. A crime against mark registration is perpetrated by anyone who imports, exports, sells, offers or displays for sale, conceals or has in stock:

I - a product bearing a mark illegally reproduced or imitated, in whole or in part, of another person; or

II - a product of his own industry or commerce, contained in a vessel, container or package that contains the legitimate mark of another person.

Penalty - imprisonment, from 1 (one) to 3 (three) months, or a fine.

\section{CHAPTER IV \\ CRIMES COMMITTED BY MEANS OFMARK, TITLES OF ESTABLISHMENTS AND ADVERTISING SIGNS}

191. Reproducing or imitating, in whole or in part and in a way that may induce to error or confusion, coats of arms, escutcheons, or national, foreign or international official badges, without the necessary authorization, in a mark, title of establishment, trade name, insignia or advertising sign, or using such reproductions or imitations for economic purposes.

Penalty - imprisonment, from 1 (one) to 3 (three) months, or a fine.

Sole Paragraph. Anyone who sells or displays or offers for sale products bearing such marks shall incur the same penalty.

\section{CHAPTER V \\ CRIMES AGAINST GEOGRAPHICAL INDICATIONS AND OTHER INDICATIONS}

192. Manufacturing, importing, exporting, selling, displaying or offering for sale, or having in stock a product that bears a false geographical indication.

Penalty - imprisonment, from 1 (one) to 3 (three) months, or a fine.

193. Using, on a product, container, wrapping, ribbon, label, invoice, circular, poster, or any other means of divulgation or advertising, modifiers such as "type", "species", "genus", "system", "similar", "substitute", “identical”, or equivalent terms, that do not safeguard the true source of the product.

Penalty - imprisonment, from 1 (one) to 3 (three) months, or a fine.

194. Using a mark, trade name, title of establishment, insignia, advertising phrase or sign, or any other form that indicates other than the real source, or selling or displaying for sale a product bearing such marks.

Penalty-imprisonment, from 1 (one) to 3 (three) months, or a fine. 


\section{CHAPTER VI \\ CRIMES OF UNFAIR COMPETITION}

195. A crime of unfair competition is perpetrated by anyone who:

I - publishes, by any means, false statements, to the detriment of a competitor, for the purpose of obtaining some advantage;

II - provides or divulges false information about the competitor in order to obtain an advantage;

III - employs fraudulent means to divert the customers of another person to his or another party's advantage;

IV - uses another person's advertising phrase or sign, or imitates it, in order to create confusion among the products or establishments;

V - uses, improperly, another person's trade name, title of establishment, or insignia, or sells, displays, offers for sale, or has in stock a product bearing these references;

VI - substitutes his own name or firm name on another person's product in place of that person's name or firm name, without his consent;

VII - attributes to himself, for advertising purposes, a reward or distinction that he has not received;

VIII - sells, displays or offers for sale, in another person's container or wrapper, an adulterated or counterfeited product, or uses that container or wrapper to negotiate a product of the same type, although not adulterated or counterfeited, provided the act does not constitute a more serious crime;

IX - gives or promises money or some other benefit to an employee of a competitor so that said employee, by neglecting his job duties, provides him an advantage;

$\mathrm{X}$ - receives money or some other benefit, or accepts a promise of payment or reward, to provide an advantage to the employer's competitor, by neglecting his duties as an employee;

XI - divulges, exploits, or utilizes, without authorization, confidential knowledge, information or data that could be used in industry, commerce or rendering of services, other than that which is of public knowledge or that would be evident to a technician versed in the subject, to which he gained access by means of a contractual or employment relationship, even after the termination of the contract;

XII - divulges, exploits or utilizes, without authorization, the kind of knowledge or information to which the previous Item refers, when obtained by illicit means or when access was gained through fraud; or

XIII - sells, displays or offers for sale a product declaring that it is object of a patent that has been filed or granted, or of an industrial design that has been registered, when it has not, or mentioning it in an advertisement or a commercial paper as being filed or patented, or registered, when it has not; 
XIV - divulges, exploits, or utilizes, without authorization, results of tests or other undisclosed data whose preparation involves considerable effort and that were submitted to government agencies as a condition for obtaining approval to commercialize products. Penalty - imprisonment, for 3 (three) months to 1 (one) year, or a fine.

(1) The hypotheses to which Items XI and XII of this Article refer include the employer, partner or officer of the company, who commits the offenses characterized in those provisions.

(2) The provision in Item XIV does not apply to the disclosure by a government agency empowered to authorize the commercialization of a product, when necessary to protect the public.

\section{CHAPTER VII \\ GENERAL PROVISIONS}

196. The penalties of imprisonment for the crimes set forth in Chapters I, II and III of this Title shall be increased by one-third to one-half if:

I - the offending party is, or was, the representative, mandatory, agent, partner or employee of the patentholder or titleholder of the registration or of his licensee; or II - the mark that has been altered, reproduced or imitated is famous, well known, or is a certification or collective mark.

197. The fines stipulated in this Title shall be set at a minimum of 10 (ten) and a maximum of 360 (three hundred and sixty) daily-fines, pursuant to the provisions of the Criminal Code. Sole Paragraph. The fines may be increased or reduced, by as much as 10 (ten) times, in view of the personal situation of the agent and the magnitude of the advantage obtained, regardless of the rule established in the preceding Article.

198. Products bearing counterfeited, altered or imitated marks, or that show a false indication of source may be seized by customs authorities, ex officio or at the application of the interested party, during verification procedures.

199. In the crimes set forth in this Title, legal action shall be taken only on the basis of a complaint, except for the crime in Article 191 in which the criminal action shall be public.

200. Criminal action and the preliminary proceedings of search and seizure, in crimes against industrial property, shall be governed by the Criminal Procedure Code, with the modifications set forth in the Articles of this Chapter.

201. In search and seizure proceedings, in a crime against patent which object is the invention of a process, the officer of the court shall be accompanied by an expert who shall make a preliminary verification of the existence of the illicit, and the judge may order the seizure of the products obtained by the counterfeiter by employing the patented process. 
202. In addition to the preliminary proceedings of search and seizure, the interested party may application:

I - seizure of the counterfeited, altered or imitated mark at the place where it is prepared or wherever it is found, before it is used for criminal purposes; or II - destruction of the counterfeited mark on the packets or products that contains it, before they are distributed, even if this implies the destruction of the packaging or of the products themselves.

203. When dealing with industrial or commercial establishments lawfully organized and that are operating publicly, the preliminary proceedings shall be limited to the inspection and seizure of the products, when so ordered by the judge, and their activity lawfully engaged in cannot be stopped.

204. Once the search and seizure proceedings have taken place, any party who has applicationed such proceedings in bad faith, in a spirit of rivalry, on a mere whim, or as a flagrant mistake shall be liable for damages.

205. An allegation of nullity of the patent or of the registration on which the proceedings are based may constitute a material for defense in criminal proceedings. The acquittal of the defendant shall not, however, cause the nullity of the patent or registration, which may only be sought through the competent action.

206. In the event that information disclosed in court, in defense of the interests of either of the parties, is characterized as confidential, whether industrial or trade secret, the judge shall order that the proceedings be held in camera, and the other party shall be prohibited from using such information for other purposes.

207. Independently of the criminal action, the aggrieved party may bring any civil suits he considers as appropriate pursuant to the Civil Procedure Code.

208. The indemnification shall be determined by the benefits the aggrieved party would have made if the violation had not occurred.

209. There shall be reserved for the aggrieved party the right to recover damages as compensation for losses caused by acts that violate industrial property rights and acts of unfair competition not set forth in this Law, but that tend to prejudice another person's reputation or business, create confusion among commercial or industrial establishments or service providers, or among the products and services placed on the market.

(1) The judge may, during the course of the proceedings itself and in order to avoid damage that is irreparable or difficult to repair, provisionally order the suspension of the violation, or of the act that gives rise to it, prior to summons for the defendant, and in case he considers it necessary, order the posting of a cash bond or a fidejussory guarantee. 
(2) In cases of reproduction or flagrant imitation of a registered mark, the judge may order the seizure of all merchandise, products, objects, packages, labels and anything else that contains the counterfeited or imitated mark.

210. Losses of profits shall be determined using the most favorable criterion to the aggrieved party, among the following:

I - the benefits that the aggrieved party would have made if the violation had not occurred;

II - the benefits made by the perpetrator of the violation of the right; or

III - the remuneration that the perpetrator of the violation would have paid to the titleholder of the violated right throughout the granting of a license that would have allowed him to lawfully exploit the property.

\section{TITLE VI \\ TRANSFER OF TECHNOLOGY AND FRANCHISING}

211. The INPI shall register the contracts involving transfer of technology, franchising and similar contracts in order that they may become effective with regard to third parties.

Sole Paragraph. The decision related to the applications for registration of contracts referred to in this Article shall be issued within a period of 30 (thirty) days of the date of the application for registration.

\section{TITLE VII \\ GENERAL PROVISIONS}

\section{CHAPTER I}

APPEALS

212. Unless expressly established otherwise, the decisions provided for in this Law are subject to appeal, which shall be presented within a period of 60 (sixty) days.

(1) Appeals shall be received in full suspensive and devolutive effects, and, where applicable, all the provisions pertinent to the examination at the first instance level shall apply.

(2) There shall be no appeal of the decision ordering definitive dismissal of a patent or of a registration application, and of the decision approving the application for a patent, a certificate of addition, or a registration of a mark.

(3) The appeals shall be decided by the President of the INPI, whereupon the administrative jurisdiction shall be ended.

213. Interested parties shall be notified so that, within a period of 60 (sixty) days, they present arguments against the appeal. 
214. For purposes of supplementing the arguments offered by way of appeal, the INPI may formulate demands, which must be satisfied within a period of 60 (sixty) days.

Sole Paragraph. After the time limit stipulated in the caput has elapsed, the appeal shall be decided.

215. The decision on an appeal is final and unappealable within the administrative sphere.

\section{CHAPTER II \\ ACTS BY THE PARTIES}

216. The acts set forth in this Law shall be taken by the parties or by their duly qualified attorneys in fact.

(1) The original, transcript, or certified photocopy of the instrument of power of attorney must be in the Portuguese language, but it shall not require consular authentication and notarization of signature.

(2) The power of attorney must be presented within up 60 (sixty) days from the date of the first act by the party in the proceedings, independent from notification or demand, under penalty of dismissal, being definitive the dismissal of a patent application, an application for registration of an industrial design and an application for registration of a mark.

217. The person domiciled abroad must appoint and retain an attorney in fact who is duly qualified and domiciled in this country, and with powers to represent that person in administrative and judicial proceedings, including receipt of summons.

218. A petition shall not be considered when:

I - it is presented outside the legal period; or

II - it is not accompanied by proof that the appropriate fee has been paid for the amount required on the date it was filed.

219. Neither a petition, opposition or appeal shall be consider, if:

I - it is presented outside the period stipulated in this Law;

II - it does not contain legal grounds; or

III - it is not accompanied by proof of payment of the corresponding fee.

220. The INPI shall, whenever possible, make use of the acts by the parties, by formulating the appropriate demands.

\section{CHAPTER III TIME PERIODS}

221. The time periods established in this Law are continuous and the right to conduct the action is automatically extinguished after it has elapsed, unless the party proves that it has not acted owing to just cause. 
(1) Just cause is considered to be an unforeseen event, beyond the control of a party that prevents it from taking the action.

(2) Once just cause has been recognized, the party shall take the action within the time limit granted to it by the INPI.

222. The calculation of the time periods excludes the first day but includes the day of the expiration.

223. The time periods begin to run only after the first working day after notification which shall be done by means of publication in the INPI official gazette.

224. When no specific stipulation is made in this Law, the time period for taking an action shall be 60 (sixty) days.

\section{CHAPTER IV \\ STATUTE OF LIMITATIONS}

225. The statute of limitations on an action to remedy damages caused to an industrial property right is 5 (five) years.

\section{CHAPTER V \\ ACTS BY THE INPI}

226. The acts by the INPI in administrative proceedings regarding industrial property become effective only upon publication in the appropriate official gazette, with the following exceptions:

I - those that does not expressly depend on a notification or publication requirement under the provisions of this Law;

II - administrative decisions, when notification is made by mail or information given to the interested party in the proceedings; and

III - internal opinions and instructions of which parties do not need to be informed.

\section{CHAPTER VI \\ CLASSIFICATIONS}

227. Classifications with regard to the subjects of Titles I, II and III of this Law shall be established by the INPI whenever they have not been established in an international treaty or agreement in force in Brazil. 


\section{CHAPTER VII}

FEES

228. Fees shall be charged for the services set forth in this Law, and the amounts of such fees and the form of collection shall be established by an act of the head of the public federal administration agency to which the INPI is attached.

\section{TITLE VIII \\ TRANSITORY AND FINAL PROVISIONS}

229. The provisions of this Law shall apply to pending applications, except as regards patentability of substances, materials or products obtained by chemical means or processes, and alimentary or chemical-pharmaceutical substances, materials, mixtures or products, and medications of any kind, as well as the respective processes for obtaining or modifying them, which shall only be privileged under the conditions established in Articles 230 and 231.

230. An application for a patent, related to substances, materials or products obtained by chemical means or processes, and alimentary or chemical-pharmaceutical substances, materials, mixtures or products, and medications of any kind, as well as the respective processes for obtaining or modifying them, may be filed by a party who enjoys protection guaranteed by a treaty or convention in force in Brazil, in which case it is assured the date of the first patent application filed abroad, provided that its object has not been introduced on any market by direct initiative of the titleholder or by a third party with his consent, and that no serious and effective preparations to exploit the object of the application or of the patent have been made, in this country, by third parties.

(1) The filing must occur within a period of 1 (one) year from the date of publication of this Law, and must indicate the date of the first filing abroad.

(2) A patent application filed on the basis of this Article shall automatically be published, and any interested party may submit comments, within a period of 90 (ninety) days, as to whether it satisfies the provisions in the caput of this Article.

(3) When Articles 10 and 18 of this Law have been observed, and once the provisions established in this Article have been satisfied and the granting of the patent in the country where the first application was filed has been proven, the patent shall be granted in Brazil, just as it was granted in its country of origin.

(4) The patent granted on the basis of this Article is assured the period of protection remaining in the country where the first application was filed, calculated from the date of filing in Brazil and limited to the period established in Article 40, not applying the provisions of its Sole Paragraph.

(5) An applicant who has filed a patent application that is still pending, related to substances, materials or products obtained by chemical means or processes, and alimentary or 
chemical-pharmaceutical substances, materials, mixtures, or products, and medications of any kind, as well as the respective processes for obtaining or modifying them, may submit a new application within the time limit and under the conditions established in this Article, attaching proof of having abandoned the pending application.

(6) The provisions of this Law apply, where applicable, to the application filed and the patent granted on the basis of this Article

231. An application for a patent related to the subject matter dealt with in the preceding Article may be filed by a national or a person domiciled in this country, in which case it is assured the date of disclosure of the invention, provided that its object has not been introduced on any market by direct initiative of the titleholder or by a third party with his consent, and that no serious and effective preparations to exploit the object of the patent have been made, in this country, by third parties.

(1) The filing must occur within a period of 1 (one) year from the date of publication of this Law.

(2) The patent application filed on the basis of this Article shall be processed pursuant to this Law.

(3) The patent granted on the basis of this Article is assured the remainder of the 20 (twenty) year protection period calculated from the disclosure date of the invention, beginning on the filing date in Brazil.

(4) An applicant who has filed a patent application that is still pending, related to the subject matters dealt with in the preceding Article, may submit a new application, within the time limit and under the conditions established in this Article, attaching proof of having abandoned the pending application.

232. The production or use, under the provisions of the previous legislation, of substances, materials or products obtained by chemical means or processes, and alimentary or chemical-pharmaceutical substances, materials, mixtures, or products, and medications of any kind, as well as the respective processes for obtaining or modifying them, even if protected by a product or process patent in another country, under a treaty or convention in force in Brazil, may continue under the same conditions as prevailed prior to the approval of this Law.

(1) No retroactive or future charge of any amount for any reason shall be permitted with respect to products produced or processes employed in Brazil pursuant to this Article.

(2) Likewise, no charge shall be permitted under the terms of the preceding Paragraph in the event that, during the period prior to the entry into force of this Law, significant investments have been made toward the exploitation of product or process referred to in this Article, even if protected by a product or process patent in another country. 
233. Applications for registration of advertising phrases and signs and of declarations of notoriety shall be definitively dismissed, and the registrations and declaration shall remain in force for the remainder of the term, but cannot be extended.

234. The applicant is assured the guarantee of priority set forth in Article 7 of Law No. 5,772 of December 21, 1971, until the end of the time period in effect.

235. The time period in effect granted under Law No. 5,772 of December 21, 1971, is assured.

236. The application for an industrial model or design patent, filed while Law No. 5,772 of December 21, 1971, was in force, shall automatically be designated as application for registration of industrial design, and the publication already done shall be considered for all legal effects. Sole Paragraph. or the adapted applications, the payments shall be taken into consideration for purposes of calculating the five-year remuneration owed.

237. The provisions of Article 111 shall not apply to the industrial model or design patent applications that were object of an examination in accordance with Law No. 5,772 of December 21, 1971.

238. Appeals filed while Law No. 5,772 of December 21, 1971, was in force shall be decided as set forth in that Law.

239. The Executive Power is empowered to promote the necessary changes in the INPI to ensure financial and administrative autonomy to that Autarky, which may:

I - contract technical and administrative personnel by means of public competition;

II - establish a salary scale for its employees, subject to approval by the Ministry to which the INPI is attached;

III - make decisions on the basic structure and internal regulations, which shall be approved by the Ministry to which the INPI is attached.

Sole Paragraph. Expenditures resulting from application of this Article shall be charged against the INPI own funds.

240. Article 2 of Law No. 5,648 of December 11, 1970, shall henceforth read as follows: "2. The principal purpose of the INPI is to enforce, at the national level, rules regulating industrial property, taking into account its social, economic, legal and technical role, and to offer comments regarding the advisability of signing, ratifying and terminating conventions, treaties, accords, and agreements on industrial property."

241. The Judicial Power is hereby authorized to create special courts to settle issues involving intellectual property.

242. The Executive Power shall submit to the National Congress a bill of law intended to accomplish, whenever necessary, the harmonization of this Law with the industrial property policy adopted by the other countries that are members of MERCOSUL. 
243. This Law enters into force on the date of its publication as regards the subject matters regulated in Articles 230, 231, 232, and 239, and 1 (one) year after publication as regards the other Articles.

244. The Law No. 5,772 of December 21, 1971, Law No. 6,348 of July 7, 1976, Articles 187 to 196 of Decree-Law No. 2,848 of December 7, 1940, Articles 169 to 189 of DecreeLaw No. 7,903 of August 27, 1945, and any other provisions contrary to this Law are to be repealed.

Brasília, May 14, 1996; 175th of the Independence and 108th of the Republic.

FERNANDO HENRIQUE CARDOSO

Nelson A. Jobim

Sebastião do Rego Barros Neto

Pedro Malan

Francisco Dornelles

José Israel Vargas

Notice: The English version of this law is provided only as a means of reference. It is noted that the Portuguese version solely constitutes the official one, for any use the reader may intend. 


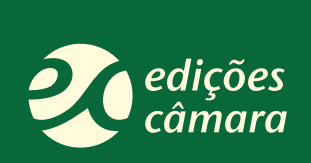

